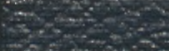

$-\cos y=3$

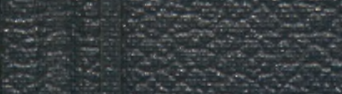

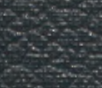

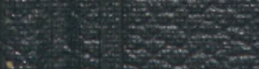

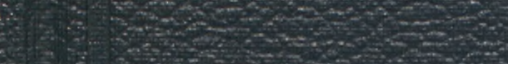

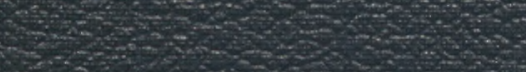


Dr. ALEXANDER HERTZ

77-05 41st Ave.
Jackson Heights, L. I., N.Y. 



\section{Poland and the American Revolutionary War}

THE Polish Roman Catholic Union of America is asking you to accept this with its compliments as a tribute to the memory of George Washington and his Polish companions-in-arms. 



\section{Poland and the American Revolutionary War}

by

Miecislaus Haiman

PUBLISHED BY THE POLISH ROMAN CATHOLIC UNION OF AMERICA FOR THE TWO HUNDREDTH ANNIVERSARY OF THE

BIRTH OF GEORGE WASHINGTON

CHICAGO, ILLINOIS

1932 
Copyright, 1932, by Miecislaus Haiman

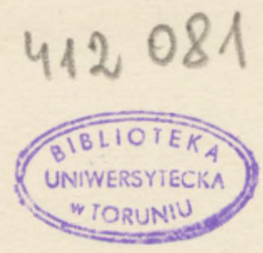

Printed by the Polish Union Daily, 1331 Augusta Blvd., Chicago, Ill.

579

$$
V .1422 / 69
$$


To the memory of

\section{GEORGE WASH INGTON, FATHER OF THE COUNTRY, FRIEND OF POLAND,}

And to the memory of those Poles who together with Him fought for

THE FREEDOM OF OUR REPUBLIC

This book is affectionately dedicated by

\section{THE POLISH ROMAN CATHOLIC UNION OF AMERICA}

JOHN J. OLEJNICZAK, President

REV. BRONISLAUS F. CELICHOWSKI, Chaplain

JOSEPH L. KANIA, Vice-President

MRS. CLARA PALCZYNSKA, Vice-President

W. J. PRZYBYLINSKI, Secretary General

JOSEPH J. BARC, Treasurer

JOHN S. RYBICKI, Attorney

M. J. BADZMIEROWSKI, M. D., Chief Medical Examiner

FRANCIS S. BARC, Editor. 



\section{FOREWORD}

The worship of heroes has its deep roots in the human soul. It turns our thoughts, too often occupied with everyday drudgery, to subjects representing lofty and inspiring ideals. Its educational value can hardly be overestimated. It is the worship of military heroes which constitutes one of the factors responsible for creating in our minds the conception of nationality.

If the idea of international solidarity has a true emotional value it is because there are certain ideals which are common to more than one nation. If the interests which form the basis of international relations sometime acquire a brim of abstract glory - it is due to those heroes whose deeds attract the imagination beyond the frontiers of one country.

I am very thankful to $M r$. Haiman that he-in this very material age - recalls in his book that two nations divided by the Atlantic Ocean and by half of the European continent have had common heroes and common hero worship before they ever exchanged the first shipload of goods.

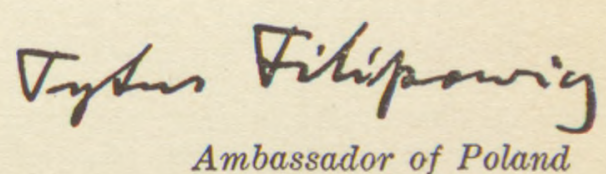

Washington, June 14, 1932. 



\section{PREFATORY NOTE}

The story of the Poles in the American Revolutionary War has been, until now, nearly entirely confined to biographies of the two most famous among them:- Brigadier Generals Thaddeus Kosciuszko and Casimir Pulaski. There exists no work in the English language which would give a general knowledge of the other Poles who "fought in freedom's holy fight." Also unknown are the relations between George Washington and his Polish friends and contemporary Poland's attitude towards the fighting Colonies.

To supply this want, to promote better relations between the United States and Poland and, above all, to honor the memory of the Man, who justly is and always will be "first in the hearts" of all true Americans, the Polish Roman Catholic Union of America, with a membership of 200,000 Americans of Polish extraction, publishes this work.

The book contains the fruits of the historical researches of the author, who has already published a series of books in the rolish language, pertaining to the history of the early Polish immigration to the United States. It is a translated, revised and enlarged edition of his recently published work, Polacy $w$ walce 0 niepodleglość Ameryki. The Polish Roman Catholic Union and the author hope that it will not only present more clearly the merits of the Poles in the war for the independence of the American nation, but also add some new and interesting facts to the history of the Revolution.

The author considers it his duty to thank President John J. Olejniczak of the Polish Roman Catholic Union, all Officers and Members of the Union, as well as Mr. Frank S. Barc, Editor-inChief of the Polish Union Daily of Chicago, for the privilege of publishing this work under their patronage and with their help.

$\mathrm{He}$ also acknowledges with gratitude the kindness of all thase who helped him in his researches, especially:- Colonel Edgar Erskine Hume, U. S. A., President of the Society of the Cincinnati in the State of Virginia; Judge Samuel Cole Williams of Tennessee; Librarian William Harden of Georgia Historical Society; Miss A. A. Nunns, Assistant Superintenident of the State Historical Society of Wisconsin; Miss Mary E. Standbridge of the Buffalo Public Library; United States Consul General L. J. Keena of Paris; General Paul Azan, Chief of the historical division of the French Ministry of War; United States Consul General N. Winship and Director Hauch-Fausboell of the Danish Genealogical Institute of Copenhagen; United States Consul General John Ball Osborne at Stockholm, Sweden; United 
States Consul General Thomas H. Bevan and Mr. H. Blom Svendsen, the Chief Archivist of the Norwegian Government, at Oslo, Norway; United States Consul E. Talbot Smith at Bergen, Norway; Mr. F. J. Audet, Chief of the Information, Public Archives of Canada, at Ottawa; Prof. Dr. L. Konopczynski of the Jagiellonian University at Cracow; Dr. A. Wojtkowski of the Raczynski Library at Poznan; Director A. Iwanowski of the Nieswiez Majorat's Museum at Warsaw; Mr. J. Bialynia Cholodecki and Dr. A. Czolowski of the City Archives of Lwow; the Directors of Czartoryski and Jagiellonian Libraries at Cracow, and many others; as well as those who helped him in the translation and technical preparation of manuscripts: Rev. J. P. Wachowski of Toledo, O.; Mr. John T. Czech, Assistant Editor of the Polish Union Daily, and especially, Rev. Brother Theophilus, C. S. C., of the Holy Trinity High School at Chicago, who was a patient and very valuable adviser of the author.

\section{PRONUNCIATION OF POLISH NAMES}

The pronunciation of Polish names is not difficult if following simple rules are remembered:

$\mathrm{j}$, is always pronounced like $y$.

i, like $e e$.

w, like English $v$.

$\mathrm{u}$, like 00 .

cz, like the English $c h$, as in child.

sz, like $s h$, as in shall.

$\mathrm{rz}$, very like the French $\mathrm{j}$, as in jardin.

szcz, like stch.

ch, very nearly like $h$.

$\mathrm{g}$, is always spoken hand, like $g$ in get. 


\section{CONTENTS}

FOREWORD - TYTUS FILIPOWICZ . . . . . VII PREFATORY NOTE . . . . . . . . IX PRONUNCIATION OF POLISH NAMES . . . . $\mathrm{X}$

I. POLAND AND THE AMERICAN REVOLUTIONARY WAR 1

II. GENERAL THADDEUS KOSCIUSZKO . • . . 15

III. GENERAL CASIMIR PULASKI • . . . . ${ }^{2} 25$

IV. OTHER POLES IN THE REVOLUTIONARY ARMY • 33

V. POLES IN THE REVOLUTIONARY NAVY . . . 67

VI. POLES IN THE LEGION OF THE "POLISH PRINCELING" 79

VII. MAJOR ELHOLM, THE CHAMPION OF POLISH AND AMERICAN LIBERTY . . . . . . . . 87

Was he a Dane, a German, a Pole, a Frenchman, a Swede or a Norvegian?

VIII. POLES AMONG THE LOYALISTS . . . . . 103

IX. A POLISH POET'S TRAVEL IN AMERICA IN $1783 \quad{ }^{-} 115$

X. JULIAN URSYN NIEMCEWICZ IN AMERICA . . 149 APPENDICES • . . . . . . . . . 191

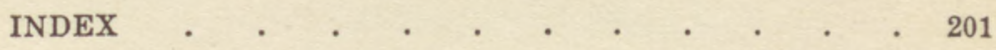



Polish heroes brave and bright

Fought in freedom's holy fight

Brilliant as the stars of night

To maintain the pure and right

John A. Joyce. 



\section{I. \\ POLAND AND THE AMERICAN REVOLUTIONARY WAR}



There were no official relations between the Republic of Poland and the United States, either during the Revolutionary War, or immediately thereafter. There existed none until recently, because there was no independent Poland.

When the Revolutionary War broke out, Poland had just emerged from a century long decadence which was but a natural reaction after a period of devastating wars for her national existence, against the several invasions of Swedes, Cossacks, Tartars, Turks, and Russians. In consequence of these wars and their effects, Poland, once one of the greatest and most progressive powers in the world, lost much of her international prestige and importance.

"All Europe is for us,"-wrote the American Commissioners at Paris to the Continental Congress, March 12, 1777. "We are glad to learn the int'ention of Congress to send Ministers to the Empire, Prussia and Tuscany; with Submission, We think Holland, Denmark, Sweden and Russia (if the Expense is no Objection) should not be neglected."1)

American diplomats thought of winning the sympathy of Tuseany, Denmark, Sweden, Holland, and that of other European states, but there is no mention in the Revolutionary documents of a project to send an American minister to Poland, which then, though deprived of much of her land through the first partition, was still quite an imposing country, far larger than some of those mentioned above.

But this was quite natural. The Colonies could not enter into commercial relations with Poland because the treacherous King of Prussia objected too strongly to the trade of the Polish port Dantzig. ${ }^{2)}$ Moreover, access to it through the Baltic was not very convenient. They could not hope for any political aid from her because her voice was then too feeble in the concert of nations and she herself was in a condition similar to that of the Colonies.

But unhappy Poland was not without influence, though indirect, on the outcome of the American Revolution. Historians hitherto never stressed the fact that it was she who then occupied the attention of Prussia and Russia, the two most dangerous powers in the world, and, perhaps, prevented them from giving aid to the British.

1) Stevens, Facsimiles, No. 1448.

2) Marquis de Pons, the French Minister at Berlin, wrote to Count de Vergennes, June 28, 1777: - "It cannot be doubted that the King of Prussia had, from the first, the project of robbing Dantzig of its trade. The thing was too easy to be resisted, and the arrangements made in this respect aim at inducing the Poles to give preference to Prussian subjects, by the enormous difference in the toll dues." (Stevens, Facsimiles, No. 1461.) 


\section{POLAND AND THE AMERICAN REVOLUTIONARY WAR}

That Frederick the Great was not a friend of the American Revolution is admitted even by German historians. A brutal despot, he could not sympathize with "rebels" in the depth of his heart. "The Americans achieved their independence without any help from Frederick," - says Friedrich Kapp. "Of any evidence of political or personal sympathy on his part there is no proof, but it is plain that he used the Americans only to advance his own interests in the game of European politics." ${ }^{3)}$ The King himself brazenly admitted that he proposes "to go over to the side on which fortune shall declare herself." 4 )

The only service he rendered to the Colonies was to put difficulties in the way of German mercenary troops which had to pass through his territory. But he did this for two very selfish reasons. These he himself discloses in his memoirs:- "The King of Prussia beheld with pain Germany deprived of its defenders, especially should a new war be kindled.... For this reason he disputed the passage of the troops which the princes granted to England, when such troops were obliged to pass through his country. This was but taking a feeble revenge for the evil proceeding of the court of London relative to the city and port of Dantzig." 5)

So the King was guided in his attitude toward the Revolutionary War mainly by his policy toward Poland. For a long time he cast greedy glances on the old Polish city of Dantzig. He wanted to gain possession of it in the first partition of Poland. The Russians opposed him, and Frederick was obliged to give up the attempt. But he knew that "in reality it was the English who, jealous of the Prussians, protected the liberties of that maritime town." 6) The Revolutionary War was to him an opportunity to get even with England on this point, but at the same time he was too cautious "not to come to extremities." 7)

If he "did not like to see the Empire deprived of all its defenders" it was principally because of his hopes of seizing more Polish territory. If he had not acquired possession of the Vistula and Dantzig in the first partition this "advantage," he thought, "was but deferred." 8) He had to watch his prey and, above all, his abettors in the crime of partitions lest they take too much to his own detriment. Accordingly, his eyes were always turned to the East, and he was obliged to keep his army constantly in readiness.

Had he to choose sides, his character, his whole conduct toward America clearly indicates which course he would have

3) Penna. - German Soc. Publ., XV. 19.

4) Posthumous Works of Frederic II, London, 1799, XXVI, 393.

5) Ib., IV, 178 .

6) Ib., IV, 58

7) Ib., IV, 178.

8) Ib., IV, 58. 


\section{POLAND AND THE AMERICAN REVOLUTIONARY WAR}

taken. This crowned robber would not hesitate a moment to join the mercenary German princes if this were consistent with his plans.

Nearly the same may be said of the Russian Empress, Catherine II. During the early years of the Revolutionary War there was constantly alive the threat of Russian reinforcements for the English in America. The Earl of Suffolk sarcastically consoled William Eden, June 20, 1775, with the hope that 20,000 Russians will soon "be charming Visitors at New York and civilize that part of America wonderfully." 9) The Revolutionary documents of 1776 and 1777 repeatedly mention this English hope and the American fear of the Russian contingent. The English considered Russia as their ally as late as 1778. 10)

"Russia had little to gain by the independence of the United States. It was the general opinion that American products would rival those of Russia in the markets of the world. As an absolute monarch Catherine had a wholesome horror of rebels and could not be expected to aid them. This was a period of Russian expansion in Poland, Turkey and the Baltic Sea trade, and Catherine was not sorry to see her rivals there, France and England, weakened in any possible way." 11)

The reason why Russia did not sell her soldiers to George III was the same as that of Prussia, namely, her greed for new conquests. Just then a new Russo-Turkish war was imminent, and this was the direct cause why 20,000 Cossacks did not come to New York to "civilize" the Americans. But Russia's main interest was in the absorption of Poland. She had to watch her constantly, just as the King of Prussia was doing.

So it may be justly said that Poland prevented these two rapacious powers from possible intervention in the Revolutionary War in America on the side of England, as it was feared in the first years of the war. Documents disclose that this fear was not unfounded. It was Poland which covered with her own body the birth of a Republic in the New World. Were Prussia and Russia not embroiled in Polish affairs, the history of the Revolutionary War might have been different, indeed.

Though Poland had soon sunk into the abyss of political annihilation, a tide of national regeneration was already rising in her bossom.

"If the partitions of Poland became possible, it was because of the disintegration of the government which had gone on for a hundred years. And yet, in 1772, this disintegration was a thing of the past. Poland lost her independence not because she

9) Stevens, Facsimiles, No. 851.

10) Ib., No. 543.

11) John C. Hildt, Early Diplomatic Negotiations of the U. S. with Russia, Baltimore, 1906, p. 18. 


\section{POLAND AND THE AMERICAN REVOLUTIONARY WAR}

was not qualified to live, but because she gave her neighbors too evident cause to dread her fitness for individual and independent existence. The pretext given for the first partition was that her state of anarchy was a standing menace to her neighbors. The real motive was the fear inspired by the order which was returning." 12)

The reign of the last King of Poland, Stanislaus Augustus Poniatowski, was the breaking point in the history of the country. Whatever may be said of him as a monarch and man, it must be admitted that he was the champion of Polish internal reforms. He was highly educated, very liberal, "the most benevolent of Kings." He spent some time in England in his early youth and spoke English fairly well. He was an admirer of Shakespeare. His court was always open to Englishmen and Americans who happened to visit Poland, and he liked to converse with them about the political affairs of their countries. He was early and greatly interested in the struggle of the American Colonies and they had a true friend in him.

Charles Lee, who in the beginning of the struggle was a great champion of American liberties and became second in command of the American army only to betray it later, was one of the English guests of the King, before he came to America. He visited Warsaw twice during the years 1765-1769 and his nomination as adjutant to the King and General of the Polish army proves that he was a welcome guest. Lee's letters full of praise for Stanislaus Augustus serve as another proof of this. To converse with him about the affairs of England and America was the King's favorite pastime.

"It is curious to hear me converse on these subjects 13) with the King; to hear me advance my doctrines, not the most favorable to monarchy, to defend even the beheading of the martyred Charles," - wrote Lee to the Earl of Charlemont from Warsaw, June 1, 1765, "but it is still more curious to hear his opinions which are singular for a crowned head; in short, he is as warm an advocate for the natural rights of mankind as was Algernon Sydney himself." 14)

The American sympathies of the King were not of a transient character. Three years later, March 20, 1768, he wrote from Warsaw to Lee, then residing in England:

"As I have not received the printed papers relating to your colonies, which you say you have sent me, I ask you again to tell me, why they do not allow your colonies to have representatives in the British Parliament? Representation and Taxation

12) Dr. L. Konopczynski, A Brief Outline of Polish History, Geneve, 1920 , p. 42.

13) I. e., the disputes of America with the mother country.

14) Lee Papers, N. Y. Hist. Soc. Coll., IV, 41. 


\section{POLAND AND THE AMERICAN REVOLUTIONARY WAR}

would then go together, and the connection between the mother and her daughters would become indissoluble; otherwise I see no alternative but oppression or entire independence.

"For the expedient of American Parliaments, or anything else of the kind by whatsoever name it may be called, appears to me likely to produce nothing but an opposition of interests between the colonies and England, as incompatible as it would be injurious to all parties.

"The English in America would then have the same relation to those of Europe that exists in the seven United Provinces, which compose a federal republic, and whose government is so defective and slow in its operations on account of the equality of power between the seven little republics respectively. The worst of all would be, that it should become necessary for the acts of the Parliament of England to be approved by an American Parliament before they can be executed in America, which would make the latter paramount to the former. This would be the same abuse that is now seen in Poland, where the Dietine of Prussia arrogates to itself the right of confirming or rejecting what the Diet of the Kingdom of Poland has decreed." 15)

Says Jared Sparks :

"These ideas, if not entirely adapted to the circumstances to which they refer, evince a liberal turn of mind and due regard for the political rights of men." 16)

There is no doubt that Stanislaus Augustus entertained the same benevolent feeling towards America during the Revolutionary War itself. When Gen. Kosciuszko returned home after his glorious career in America, the King received him in audience and later made him Major General of the Polish army. Louis Littlepage of Virginia was one of the King's most confidential secretaries for many years, though he did not well repay Poland for this favor. ${ }^{17\}}$ Another of the King's American employees was Philip Mazzei, an Italian physician, "a man of ability, though somewhat erratic," a friend and neighbor of Thomas Jefferson and James Madison, and an agent of Virginia to procure army supplies in Europe during the Revolutionary War. ${ }^{18)}$ John Ledyard, the famous American traveler, found in Poland a haven of hospitality after his rough treatment by the Russian Empress, Catherine II. 19) John Paul Jones was the King's guest, in 1789. "I remained in Poland two months and was treated with the greatest hospitality and politeness by the King and people of fashion," -

15) Ib., IV, 65.

16) Ib., VII, 223. $137-168$.

17) M. Haiman, Polacy wśród pionierów Ameryki, Chicago, 1930, p. p.

18) William and Mary College Quarterly, ser. 2, vol. V, p. 9.

19) J. Sparks, Adventures of J. Ledyard, London, 1834, p. 371. 


\section{POLAND AND THE AMERICAN REVOLUTIONARY WAR}

wrote he to Chevalier Burgoing, the French Minister at Hamburg. ${ }^{20)}$

That the American war created considerable interest in Poland we may judge from the number of contemporary Polish prints concerning the American Revolution. ${ }^{21)}$ Some of them were published by Michael Groell, the King's printer at Warsaw. 22) They were mostly translations, as for instance: The Political History of the Present American Revolution by the celebrated Thomas Raynal, translated from the French by F. Siarczynski. Soon after the war the famous Polish historian and traveler, Count John Potncki, planned to write the history of America, probably the first original one in the Polish language, as may be judged from his correspondence with Thomas Jefferson. His early tragic death prevented him from carrying out his plans. ${ }^{23)}$

In the possession of the New York Historical Society there is a curious paper which testifies to the American sympathies of the Polish people in general. It is a memorial of Paul Mostowski, Palatine of the Duchy of Mazovia, to the Continental Congress proposing to found a "New Poland" somewhere in "Florida, Carolina or Virginia" and declaring that the Palatine "is disposed to aid the very illustrious Colonies in this heroic War, supplying them with that which they will find most useful and advantageous in their present circumstances. This is a Balm with which the wounded soldiers can radically cure themselves at once in the course of six or seven days, without the aid of surgery and in this short space of time be ready to take up arms and return to the combat."

It matters not what the modern medics may say about the wonderful properties of the balm; the offer was in the spirit of the 18th century and it is the motive of the author that counts. The Palatine said in his memorial:- "A Citizen of a Free Republic and a Senator of the first rank (which is more than Duke and Peer in France), he glories that the very illustrious Colonies should deliver themselves from the despotism which crushes them, and he hopes to see them enjoy the sweets of liberty similar to that which reigns in his Country." ${ }^{24)}$

Rejoicing over the American victory, the Polish Masonic Order of Knights of Divine Providence sent a letter to Washington, August 28, 1783, asking him "to nominate a number of suitable persons to be created Knights of the Order." The Commanderin-Chief referred the letter to Congress which, however resolved to inform Chevalier Jean de Heintz, secretary of the Order, "that

\footnotetext{
22) A. Pawinski, Michal Groell, Cracow, 1896, p. p. 85-125.

23) Lipscomb, Writings of Thos. Jefferson, XIII, 61.

24) Mag. of American History, II, 47.
}

20) R. DeKoven, John Paul Jones, N. Y., 1913, II, 370. 1931 , p. 34 .

B. Olszewicz, Poland and the Discovery of America, Poznan, 


\section{POLAND AND THE AMERICAN REVOLUTIONARY WAR}

Congress are sensible of their attention, but they cannot, consistently with the principles of the Confederation, accept of their obliging proposal." ${ }^{25)}$

It was a descendant of Polish immigrants in Holland, Peter Stadnitski, who was the first from among the great bankers of Europe, to offer financial aid to the young Republic and, through the Holland Land Co., played a prominent part in her early economic life. ${ }^{26)}$

When America was still in her teens, a Pole uttered a most striking prophecy about her future - and one which proved astonishingly true. It was Joseph Wybicki, author of the Polish national hymn, Poland is not yet lost, a contemporary of Pulaski and Kosciuszko, who wrote shortly after the Revolutionary War:

"The English colonies, as we may judge from their new system of government, from their national maxims modeled after those of the old free Romans, will become shortly the greatest power. 0 , how many inhabitants oppressed by the many infirmities of Europe, will come to America and rejoice in her happiness there!" 27)

Poland and her King were now the objects of reciprocal sympathies of eminent Americans. The King corresponded with some of them. When Poland, chiefly through the efforts of the King, adopted the famous Constitution of the Third of May, America warmly applauded her and her King. John Paul Jones, then at Paris, sent his congratulations to Warsaw. American poets sang the King's praises in verse. Joel Barlow thus concludes his Conspiracy of Kings:

"In northern climes, where feudal shades of late

Chill'd every heart and palsied every state,

Behold, illumin'd by th' instructive age,

The great phenomenon, a sceptred sage.

There Stanislaus unfurls his prudent plan,

Tears the strong bandage from the eyes of man,

Points the progressive march, and shapes the way,

That leads a realm from darkness into day."28)

Among the collections of the Library of the Polish Acaldemy of Sciences in Cracow there exists, unknown to America, an interesting letter of another famous Revolutionary poet, David Humphreys, containing his ode on the King of Poland.

Humphreys, then American Minister at Lisbon, wrote to Gen. Kosciuszko, October 1, 1791:

"I have been so sincerely and so much delighted with the conduct of the King of Poland, that I could not refrain from

25) Journals of Cont. Congress, Jan. 5, 1784.

26) M. Haiman, Polacy wśród pionierów Am., p. p. 45-56.

27) Speech of Count Francis Pulaski at Philadelphia, Oct. 17, 1929.

28) Political Writings of Joel Barlow, N. Y., 1796, p. 251. 


\section{POLAND AND THE AMERICAN REVOLUTIONARY WAR}

testifying my sensation to the world in a little Poem, which I am now writing for publication, the lines are these,

"To thee, thou Sage of higher, nobler sort, Than e'er before adorned an earthly Court, Parent of Millions! Paragon of Kings!

A Bard from new-found Worlds new laurel brings, To thee, great Stanislaus! - Thy glorious name Shall stand unrivalled on the rolls of fame Hail patriot King! And hail the Heav'n-born plan Thy voice pronounc'd to fix the rights of man; The godlike voice, that op'd the feudal graves, Call'd to new life innumerable Slaves, Nor call'd to life alone.... Inspir'd by thee Thy gen'rous Nobles made those Vassals free. -

Hail blest example! Happy Poland hail!

No more.... to lure thy foes.... shall feuds prevail;

No more shall bord'ring Pow'rs, with lawless arms, Divide thy confines and despoil thy farms;

No more shall slav'ry sterilize thy soil,

But fruits, that prompt, shall pay the Peasant's toil;

While soothing faction'l rage, fair Concord reigns, And crowns with bliss the plenty of the Plains;

While Age succeeding Age, a patriot King!

Both Worlds admire and all the Muses sing." 29)

No edition of Humphrey's Poem on National Industry in which the poet planned to include the above lines, contains them. Before he was able to publish it, Poland was no more and Stanislaus Augustus was an exile.

George Washington also accepted the news of the Polish Constitution with warm praise.

"The example of France" - wrote he to Humphreys from Philadelphia, July 20, 1791, "will undoubtedly have its effects on other Kingdoms. Poland, by the public papers, appears to have made large and unexpected strides toward liberty; which, if true, reflect great honour on the present King, who seems to have been the principal promoter of the business." 30 )

Kosciuszko's Insurrection in behalf of Poland's freedom which followed the Constitution of the Third of May was largely influenced by the American Revolution. This may be observed in his methods of action and his system of organization of the armed forces. His manifesto promising freedom to peasants who will take up arms for the country was a modified echo of

29) MSS of the Polish Academy of Sciences, Cracow, No. 1171-88.

30) F. L. Humphreys, Life and Times of David Humphreys, N. Y. 1917, II, 125 . 


\section{POLAND AND THE AMERICAN REVOLUTIONARY WAR}

the Declaration of Independence. It was during that war that he said: "The name of an American is always sacred to me" to Louis Littlepage who appealed for his protection against the justice of the revolutionary tribunals. ${ }^{31)}$ In his holy fight for freedom Kosciuszko used a sword which was sanctified by the memory of his friends in America. It was a gift to him from Washington himself, as may be supposed from the inscription on it: "America cum Vashington suo Amico T. Kosciusconi." The sword, which came into the hands of the Russians after the battle of Maciejowice when the wounded Kosciuszko fell on the field, is now one of the most sacred treasures of the Polish National Museum at Warsaw. ${ }^{31 a)}$

"You was raised up by the Lord of Hosts to be an instrument of saving the United States from slavery," wrote Rev. William Gordon, historian of the American Revolution, to George Washington, September 12, 1794. "I most sincerely wish, that the same Omnipotent Power may have commissioned Kosciuszko to deliver the Poles from under slavery." 31b)

Poland is far from America; and if there were any volunteers in this country for the service under Kosciuszko, the distance and political difficulties made it impossible for most of them to join him in time. But there were a few Americans who, fired by their sympathies for Poland, actually enlisted in the Polish army and fought Kosciuszko's battles for freedom.

One of them was Captain Abner Crump of Virginia who "eager to repay a small part of what our new nation owed to Polish assistance in that dark hour," joined his friend, Kosciuszko, and served on his staff in the Polish-Russian war of $1792 . \mathrm{He}$ took part in the battle of Dubienka and evidently made the whole campaign with great honor, as is attested by the Cross of Virtuti Militari ${ }^{31 \mathrm{c})}$ which he received. But when the cause of the patriots was lost and Kosciuszko and other high officers of the army re-

31) M. Haiman, Polacy wśród pionierów Am., p. 159.

31a) There exist also in the Polish National Museum in Cracow a pair of pistols of Kosciuszko with the following inscription engraved on their barrels: "G. Washington 17 E Pluribus Unum 83 Th. Kosciuszko," The pistols are richly ornamented with gold and bronze; ther wooden parts are of mahogany. They were evidently a gift from Washington. (K. Buczkowski, "Bezcenne Pamiątki po Waszyngtonie i Kościuszce," Światowid, vol. IX, nr. 9, p. 21) M. le Baron de Girardot in his L'Ordre Americain de Cincinnatus en France (Nantes, w. d.; p. 50) mentions still another of Washington's gifts to Kosciuszko. It was an antique cameo mounted on a ring which the French Society of the Cincinnati presented to Washington who in turn gave it to Kosciuszko. The latter made a gift of it to Baron de Girardot who served in the Polish Chevau-Legers of the Imperial Guard.

31b) Mass. Hist. Soc. Proceedings, vol. LXIII, p. 573.

31c) It was the highest award for military valor, created by Poland in the 18th century. Gen. Kosciuszko was also decorated with it. The reborn Poland resurrected this Order, one of the oldest in the world. 


\section{POLAND AND THE AMERICAN REVOLUTIONARY WAR}

signed their commissions and went into a voluntary exile, Capt. Crump also left Poland and returned to America. ${ }^{31 d}$ )

Another American in Kosciuszko's army was John Phillips Ripley of Philadelphia, a graduate of Dartmouth College, who fought in the Polish Insurrection of 1794 and, captured, spent nine months in a Russian prison. ${ }^{32}$ )

The lot of Kosciuszko was similar to Ripley's.

“Tho Austria's Keiser and the Russian Czar

To dungeons doom them and with fetters mar,

Fayette o'er Gaul's vast realm some light shall spread,

Brave Kosciuszko rear Sarmatia's head." ${ }^{33)}$

Soon followed the third and last partition of Poland. She ceased to exist politically. ${ }^{34)}$ The event evoked much sympathy in America. David Humphreys, the "belov'd of Washington," expressed the indignation of his country:-

31d) Col. Edgar Erskine Hume, U. S. A., President, Society of the Cincinnati of Virginia, a descendant of Capt. Crump, kindly furnished the author with the following particulars: "Abner Crump, son of Benjamin Crump of Round Hill, Fauquier County, Virginia, where he was born about 1749 . Served in several Indian campaigns under Colonel George Washington, as a junior officer. In the American Revolution was Captain in the Virginia State Line (First Virginia Regiment). Original Member of the Order of the Cincinnati. During this war became a friend and admirer of Colonel Tadeusz Kosciuszko. Letters were exchanged between Crump and Kosciuszko, the latter apparently having an unusual ability to remember all officers with whom he came in contact. Crump's admiration of Kosciuszko and the cause that he went to Poland to serve in 1784, made him offer his services to the Polish cause. The date of his going to Poland and the means taken to get there are not known. In a letter to his niece, Crump wrote, 'None can exaggerate the feeling of elation that came over me when I learned that an opportunity had come to me to offer my poor services to the Patria of that great man, Kosciuszko, and I hoped that it might be granted in some way thus to repay a small part of what our new nation owed to Polish assistance in that dark hour. While I had not been under arms for almost a decade I trusted that there might be something that I could do, and when my offer was accepted I set sail for the Old World with as much enthusiasm as did my grandfather who came to the Colony from England to avoid oppression of the German kings that had been set to rule over England by those who did not trust the old line of rulers who had been good enough for our ancestors for centuries.' Crump served in Poland attached to the staff of Kosciuszko and was present at Dubienka. After the second partition of Poland he returned to Virginia. He was rewarded for his services by the bestowal of the Order of Virtuti Militari, the eross of which together with his Eagle of the Cincinnati have passed to his descendants."

32) E. P. Kelly, "Dartmouth College and Poland", Poland, XI, 279.

33) Joel Barlow, Columbiad, London, 1809, Book V, verses 679-682.

34) Thomas Jefferson was afraid that the fate of Poland might in time befall America. He wrote to James Madison from Paris, Dec. 20, 1787, during the discussion concerning the Constitution of the United States: "The second feature I dislike, and strongly dislike, is the abondonment, in every instance, of the principle of rotation in office, and most particularly in the case of the President. The election of a President of America, some 


\section{POLAND AND THE AMERICAN REVOLUTIONARY WAR}

"If we to Heav'n our unavailing vows For Poland rais'd - besought Heav'n's righteous Lord,

To rend the wreath from Austria's, Prussia's brows, And break of baneful leagues the threefold cord;

With horror mark'd the Empress of the North, Her wheels yet reeking o'er the mooned host,

Rouse the dull Russ, and call the Cossac forth

From darksome dens of everlasting frost;

Of every class, ye proud opressors hear!

"I hate your conduct, and your anger brave." ${ }^{5}$ )

The unhappy Stanislaus Augustus remained true to America even after he lost his throne. He admired Washington and probably in the depth of his heart lamented that he could not imitate his fortitude, perseverance and strength of character which he so sorely lacked, to lead his nation. The King more than once tried to reach the great American with his letters. There are mentions, at least, that he sent him a letter in 1790 , probably congratulating Washington on his election as President of the United States; but this letter did not reach its destination. It was lost through the carelessness of Littlepage, the King's secretary.

But there exists yet another letter of the King to Washington, very characteristic of his feelings toward America and toward "The Father of the Country." It was written in 1795, just after the last partition of Poland, when Stanislaus Augustus was the prisoner of the Russians at Grodno. Choosing Littlepage as the

years hence, will be much more interesting to certain nations in Europe, than ever the election of a King of Poland was. They will interfere with money and arms" to force the election of a man convenient to them. "No foreign power, nor domestic party will waste their blood and money to elect a person, who must go out at the end of a short period. The power of removing every fourth year by the vote of the people, is a power which they will not exercise, and if they were disposed to exercise it, they would not be permitted. The King of Poland is removable every day by the diet. But they never remove them. Nor would Russia, the Emperor, etc., permit them to do it." - To Mr. A. Donald, Paris, Feb. 7, 1788, Jefferson repeats nearly the same and adds: "The importance to France and England, to have our government in the hands of a friend or a foe, will occasion their interference by money, or even by arms. Our President will be of much more consequence to them than a King of Poland." (Lipscomb, The Writings of Thos. Jefferson.) Rev. William Gordon, historian of the American Revolution, wrote on the same subject to George Washington, August 17, 1793: "I am fully convinced that one, if not more, of the persons in the United States is of opinion, that in time an hereditary President must be chosen, to prevent the dangerous contests that periodical elections will produce, similar to what has happened repeatedly in choosing Polish sovereigns." ("Letters of the Rev. Wm. Gordon," Mass. Hist. Soc. Proceedings, vol. LXIII, p. 570.)

35) D. Humphreys, A Valedictory Discourse, Boston, 1804. 


\section{POLAND AND THE AMERICAN REVOLUTIONARY WAR}

messenger to "convey to you the testimony of my sentiments," the King recommended him to Washington and said:

"Your conduct in war and in peace has inspired me for a long time with the desire of expressing to you the high esteem in which I bear you. It will be pleasing to me that an American shall bear the marks of my esteem and affection in the midst of his compatriots, in the midst of that nation which has known how to win for itself already such an opinion from the inhabitants of the old Hemisphere, that it is able in many ways to serve them as a lesson and a model." ${ }^{36)}$

Washington's opinion of the Constitution of the Third of May was not the only expression of his sentiments toward Poland. These were always most friendly.

When Kosciuszko arrived in America on his second visit, after his unsuccessful struggle for the liberty of Poland, Washington, welcoming him, gave assurance that "no one more sincerely wished, during your arduous struggle in the cause of Liberty and your country, that it might be crowned with success." 37 )

Julian Ursyn Niemcewicz, the Polish soldier, poet and statesman, who accompanied Kosciuszko on his second journey to America, spent a few weeks at Mount Vernon as a guest of Washington. During that time he often spoke with his host about the fate of his country. He notes in his memoirs that once during such a conversation the venerable American declared:

"I always wished well to her (Poland) and that with all my heart." 38)

In a beautiful verse Niemcewicz immortalized another touching episode of his stay at Mount Vernon. It was during a conversation with Washington on the wrongs of Poland, her vain efforts to regain freedom, her lost hopes, her tragic division amiong the three oppressors. Washington seemed to be absorbed in the tale. To the astonishment of Niemcewicz, a tear appeared trickling down the cheeks of the old hero.

To the same Niemcewicz Washington again disclosed his sentiments on Poland:

"That your country is not as happy as her efforts were patriotic and noble, it is a misfortune which all the lovers of sensible liberty and rights of men deeply deplore; and, were my prayers during that hard struggle of any good, you would be now 'under your own wine and fig tree', to quote the Bible, as

36) H. E. Hayden, Virginia Genealogies, Wilkes-Barre, 1891, p. p. $395-420$.

III, 190 .

Spark's Writings, XI, 214; Griffin, Catholics and the Am. Rev. 510 .

38) W. M. Kozlowski, “A Visit to Mount Vernon," Century Mag. XLI, 


\section{POLAND AND THE AMERICAN REVOLUTIONARY WAR}

happy in the enjoyments of these desirable blessings as the people of these United States enjoy theirs." 39 )

All these expressions of Washington show clearly his noble and sympathetic attitude toward Poland. He was one of her best friends on this side of the Atlantic.

The news of Washington's death was accepted by the Poles with profound sorrow. They were not allowed by their oppressors to express their sentiments in their country, but Kosciuszko and Generals John Henry Dombrowski and Charles Kniaziewicz, the leaders of those patriots who left Poland after her partitions to seek in exile means of restoring her to independence, adopted mourning. Their example was followed by the entire Polish colony in Paris. Gen. Dombrowski, who commanded the Polish Legion in Italy, issued an official order that all the soldiers should wear the usual mourning and that their banners should be draped with shrouds. ${ }^{46)}$

As time passed, friendship for Poland grew into an American tradition, just as friendship for America became traditional in Poland. During Poland's reverses the sympathies of America were always on her side, on the side "of that brave and generous people, who have for centuries been battling against the sceptered plunderers of Europe and tramplers upon the common rights of man." 41$)$

This zeal to battle "against the sceptered plunderers and tramplers upon the common rights of man" brought Kosciuszko, Pulaski and other Poles to America. Their presence in the Revolutionary ranks is the strongest proof of the Polish sympathies in the beginnings of this nation. Since those days the world has changed many times. Poland is again alive - "The Knight Among Nations." But the friendship between America and Poland never changed. These sentiments of old are still alive. Sanctified by the blood of Revolutionary heroes, may they live forever.

39) J. U. Niemcewicza Pism Różnych, Warsaw, 1803, vol. I. p. 316.

40) S. Askenazy's lecture at Washington's Bicentennial ceremonies at the City Hall in Warsaw, February 22, 1932, Nowy Swiat, March 21, 1932.

41) Resolution of the Legislature of New Hampshire, June 1842; M. Haiman, Z Przeszłości Polskiej w Am., p. 328. 

II.

GENERAL THADDEUS

KOSCIUSZKO 

A voice from the glorious dead!

Awake to the call of fame!

By yon gorgeous banner's spangled folds, And by Kosciuszko's name! 1)

The first foreign patriot to heed the call of the "shot that was heard around the world," and the first to come to the aid of the American colonies in their struggle for freedom, was Thaddeus Kosciuszko.

Today his name is familiar to and revered by the whole civilized world; but when he first came to Philadelphia in the summer of 1776, a few weeks after the Declaration of Independence, he was a young military engineer, still unknown to his future companions-at-arms, and too modest to ask anything else than a mere chance to do the "Sacred Duty which has engaged him to Defend this Country." ${ }^{2)}$

"He had arrived, indeed, at a fortunate moment, for hostilities had but recently commenced, and the defenders of liberty, although numerous, active and resolute, were at the same time raw, ignorant, undisciplined and unacquainted with everything that appertains to the art of war. To such an army this young and spirited Pole became a treasure." 3 )

"Kosciuszko had placed his rare gifts at the service of a less ill-starred Revolution than that with which his name is romantically and pathetically associated." 4) He "threw himself into the military contest on the side of the colonies with dashing ardor and consummate ability." 5)

Having been sent to the Northern Army, which was then opposing the advance of Burgoyne, he prepared the defenses of Ticonderoga. It was his plan to fortify the Sugar Loaf Hill which overlooked Ticonderoga and Mt. Independence and was at that time occupied by the Americans. The plan was approved by Gen. Gates, who highly esteemed Kosciuszko's abilities. Unfortunately, Gates was recalled, and his successors, Gen. Schuyler and Gen. St. Clair set aside the plan as impracticable. The British, however, occupied Sugar Loaf Hill shortly thereafter and did exactly what Kosciuszko had been planning to do for the American army, thereby forcing Gen. St. Clair to evacuate Ticonderoga. Had the Generals heeded Kosciuszko's advice, they would have, perhaps, saved this valuable position for the

1) J. B. Strong, "West Point," New York Mirror, July 29, 1833.

2) Kosciuszko to Gates, May 18, 1777, Gates Papers, N. Y. Hist. Society Coll.; Griffin, Catholics and the Amer. Rev. vol. III, p. 141.

3) Analectic Magazine, vol. XI, p. 424.

4) Trevelyan, The American Revolution, vol. II, p. 174.

5) Speech of Dr. Emmett J. Scott, Washington, D. C., Oct. 18, 1926.

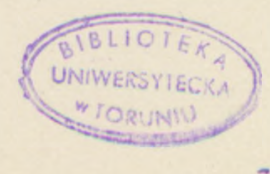


Americans, and Gen. St. Clair would have spared himself the annoyances of a trial. ${ }^{6)}$

Kosciuszko's professional skill contributed much to the safe retreat of the Northern Army. Directed by Gates to choose a new strong position, he selected the field of Saratoga and "covered its weak points with redoubts from the hill to the river." "7)

"Throwing into the duties of a military engineer his fiery energy, and something of his national tendency towards the grandiose, he had crowned Bemis' Heights with a stronghold which resembled a citadel rather than a temporary field-work." ${ }^{8}$

This battleground was the "Thermopylae of the American Independence." Kosciuszko's "strategic skill in the fortification of Bemis' Heights was an important factor in our victory at Saratoga," said recently the Hon. Dwight F. Davis, former secretary of War. 9) Other authorities also acknowledge the importance of Kosciuszko's work in this victory of the Americans. "It was the gallant Polish patriot Tadeusz Kosciuszko who had shown Gen. Gates how to entrench himself on Bemis' Heights", says Woodrow Wilson ${ }^{10}$ ) and Professor Channing similarly extols his merits:- "The credit of Saratoga belongs to Horatio Gates, and with him to Daniel Morgan, Benjamin Lincoln and Thaddeus Kosciuszko." 11)

Gen. Gates in his official report of the victory at Saratoga informed Congress: "Col. Kosciuszko chose and entrenched the position," "12) and to a friend congratulating him on the victory he said: "The hills and woods were the great strategists which a young Polish engineer knew how to select with skill for my camp." 13)

"In all likelihood the War for Independence would not have terminated with success to the new Nation had it not been for the assistance given by France. This assistance was given only as a result of the surrender of the British Army at Saratoga." 14) Therefore, the skill of Kosciuszko at Saratoga contributed in a very great measure to the recognition of the United States by France and to the ultimate victory of the Colonies.

By a resolve of Congress Kosciuszko was then sent to West Point in order to strengthen the defenses of the Hudson. He spent there over two years. "Kosciuszko's work at West Point was the longest and the most important of his undertakings in the United States, and is inseparably connected in the American mind with

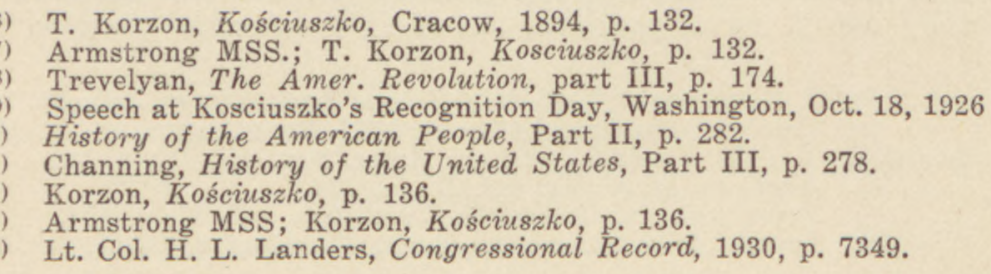




\section{GENERAL THADDEUS KOSCIUSZKO}

his name." 15) His conduct and his work there similarly elicited the highest praises. Said Washington: "To his care and sedulous appreciation the American people are indebted for the defense of West Point." 16) In the opinion of the Hon. D. F. Davis, "his engineering skill contributed to the efficient fortification of West Point where his handiwork, even more than the monument in his honor today, serves as a constant inspiration to our military students." 17) And General Armstrong wrote: "Kosciuszko's merit lies in this that he gave the fortifications such strength that they frightened the very enemy from all temptation of even trying to take the Highlands." 18)

Many touching episodes are connected with his stay at West Point. Moved by the misery of the English prisoners of war kept there, he divided with them his own modest rations and payand thus saved many a one from death by hunger. In a secluded spot among the rocks he planted a flower garden and, as the place was inaccessible to vehicles, he carried the earth there himself in baskets. The place still bears the name Kosciuszko Garden, and it was there that the young Pole spent his leisure hours, dreaming of his far off country.

In August, 1780, Kosciuszko at his own request was transferred to the Southern Army. He wanted to be with his old friend, Gen. Gates. Before he could join him, however, Gates was defeated at Camden, S. C., and Greene was appointed in his place.

Kosciuszko's services to the American cause in the difficult southern campaign were equally distinguished. He made many surveys of the fields of operation and planned as well as executed ways of rapid transportation of troops, a matter of utmost importance in campaigns conducted in a country of rivers and swamps. In emergencies or when not engaged in the work of an army engineer, he fought in the ranks as a line officer. He made the entire campaign under Greene till the evacuation of Charleston, and fate preserved for him the honor of firing the last shot in the American Revolution in the skirmish at James Island, Nov. 14, 1782.19) "A great and good man," 20) he saved the lives of fifty British soldiers whom the Americans threatened to slaughter in the heat of fighting at Eutaw Springs.

General Greene considered him a "master of his profession" 21 ) and always spoke of him with the warmest praise.

15) Monica M. Gardner, Kosciuszko, London, 1920, p. 41.

16) Griffin, Catholics and the Amer. Rev., vol. III, p. 153.

17) Speech at Washington, D. C., Oct. 18, 1926.

18) Korzon, Kościuszko, p. 140.

19) Penna. Magazine of Hist. and Biogr., vol. 1X, p. 109. III, p. 129 .

20) J. Coxe Barnet to Jefferson, Paris, Nov. 30, 1817; Griffin, vol.

21) Greene to Gov. Burke, Aug. 12, 1781; A. Kahanowicz's Thaddeus Kosciuszko Memorial Exhibition, p. 35. 


\section{POLAND AND THE AMERICAN REVOLUTIONARY WAR}

From Charleston, July 10, 1783, he wrote to Kosciuszko: "It will add to my happiness to hear from you in whatever quarter of the world you are. Permit me to return you my sincere thanks for the zeal with which you have served the public under my command and for your friendly disposition towards me. My warmest approbation is due to you as an officer and my particular acknowledgment as a friend. ${ }^{22)}$

In the same spirit, but at greater length, did Gen. Greene write on another occasion:

"One of the most useful and amiable from among my comrades-in-arms was Colonel Kosciuszko. His zeal for public service seems to be incomparable and in the solution of complicated problems, which we had to meet from time to time in the intermittent but active war, there could have been nothing more useful than his opinion, his watchfulness and his constant application to the task in hand. In the execution of my orders he has always been willing, competent, inaccessible to any temptation of pleasure, not fatigued by any labor, intrepid in any danger. He is incomparably modest. He has never expressed a desire for anything in his favor, and has never omitted an opportunity to commend and reward the services of others." 23 )

At the end of the war Kosciuszko was accepted into the Society of the Cincinnati, whose members are to this day "proud of having on their roll the name of so true a man and soldier."23a)

Congress tardily rewarded Kosciuszko with a brevet commission of Brigadier General, October 13, 1783, as a token of the "high sense of his long, faithful and meritorious services." In 1784 he returned to Poland to serve his own country. He distinguished himself in the Polish-Russian campaign of 1792, and two years later the whole world resounded with his name when he assumed the leadership of the Polish Insurrection to throw off the yoke of the crowned despots who conspired for Poland's death. Though his heroic efforts failed to achieve the desired result, the moral influence of his struggle never ceased to affect deeply the national life and aspirations of the Polish people.

"Oh, bloodiest picture in the book of Time,

Sarmatia fell, unwept, without a crime....

Hope for a season bade the world farewell

And freedom shrieked as Kosciuszko fell." ${ }^{24)}$

After spending two years in the dungeons of St. Petersburg as a prisoner of war, he was finally liberated by Czar Paul I.

22) Greene to Kosciuszko, Ib., p. 37.

23) Korzon, Kościuszko, p. 163.

23a) Anthony Walton White Evans, Memoir of Thaddeus Kosciuszko, Poland's Hero and Patriot, New York, 1888, p. 4.

24) Thomas Campbell, Pleasures of Hope. 


\section{GENERAL THADDEUS KOSCIUSZKO}

He immediately set out for America which he always considered his "beloved country, whose reputation was dear to him." 25)

Kosciuszko's passage through Sweden and England was like a triumphal procession. He was greeted with equal enthusiasm at Philadelphia where the "citizens insisted upon drawing his carriage to his lodgings." 26) Washington welcomed him with a letter to the land "whose liberties you had been so instrumental in establishing." 27)

Because of yellow fever which ravaged the population of Philadelphia at that time, Kosciuszko was obliged to leave the city and spent some time in the homes of his old friends, Gen. Anthony Walton White at New Brunswick and Gen. Gates in New York. Everywhere he was the subject of public esteem, and there was no end of visitors and admirers who came to see him. Thomas Jefferson, then the Secretary of State, wrote to Gates: "I see Kosciuszko often. He is the purest son of liberty which extends to all not alone to the rich." ${ }^{28)} \quad$ So also did Gates say of him: "Kosciuszko is the only pure republican I ever knew. He is without any dross." 29)

It was the intention of Kosciuszko to settle in America for the remainder of his life. But in March, 1798, he received a secret summons to return to Europe because Napoleon planned to restore Poland to her rank among the nations. $\mathrm{He}$ left immediately under an assumed name, intrusting to Jefferson his will which is, really, the finest monument he himself erected to his own memory in America:

"I, Thaddeus Kosciuszko, being just on my departure from America, do hereby declare and direct that, should I make no other testamentary disposition of my property in the United States, I hereby authorize my friend, Thomas Jefferson, to employ the whole thereof in purchasing negroes from among his own or any others, and giving them liberty in my name; in giving them an education in trade or otherwise; in having them instructed for their new condition in the duties of morality, which may make them good neighbors, good fathers and mothers, husbands and wives, in their duty as citizens; teaching them to be defenders of their liberty and country, of the good order of society, and in whatsoever may make them happy and useful.

" 5 -th of May 1798.

T. Kosciuszko".

"In this will, written 65 years before Abraham Lincoln issued the Emancipation Proclamation, the Polish patriot pleaded

25) Kosciuszko to Major Haskell, Warsaw, May 15, 1789; Kahanowicz, Kosc. Mem. Exhibition, p. 14.

26) Claypoole's Advertiser, August 19, 1797.

27) Sparks, Writings of Washington, vol. XI, p. 214; Griffin, vol. III, page 190 .

28) Feb. 21, 1798. Griffin, vol. III, p. 198.

29) Diary of Wm. Dunlap, N. Y. Hist. Soc. Collections, 1929-31, vol. I, page 338 . 


\title{
POLAND AND THE AMERICAN REVOLUTIONARY WAR
}

for the emancipation of American slaves and gave the whole of his modest fortune to be employed in purchasing and freeing them in his name, in giving them an education, and in having them instructed so that they might become good citizens - happy and useful men and women.... In spirit and purpose he was a pioneer in both the efforts to emancipate the slaves and in the effort to train them for worthy citizenship." 30 )

Aside from its merely humanitarian point of view, his will, it should be stressed, pointed to America the only satisfactory means of solving the question of slavery. In the American Civil War, the Southern people insisted that slavery was not the main issue, and said that if it were that the only solution would be the purchase of the slaves. Even Lincoln only freed the slaves in the seceeding states, while the legislatures of some of the Union states freed the slaves within their confines. Had the advice of Kosciuszko found a general application, then certainly America would have been spared the curse of the Civil War.

After the death of Kosciuszko complications arose concerning the execution of this will and the wishes of the great Pole were never carried out.

Before his death Kosciuszko once more did service to America. In 1800, in Paris, he wrote Manoeuvres of Horse Artilery for the United States Army. It was "the first instance of American artillery being authoratively supplied with a general system of instructions"; the war of 1812 was fought by artillery in accordance with these Manoeuvres. "Consequently it may be justly and fairly claimed that General Kosciuszko was The Father of the American Artillery." 31)

One of the most noteworthy passages in this famous book is the following:

"The use of artillery in battle is not against the artillery of an enemy, for that would be a waste of powder, but against the line of the enemy in a diagonal direction when it is destructive in the extreme." ${ }^{31 a)}$

It is thought that Kosciuszko was the first military man to advance this idea, which is now a fundamental principle in all armies.

Kosciuszko died at Soleure, Switzerland, October 15, 1817, far from his beloved Poland and America.

\author{
"His dust in Poland rests- \\ His urned Heart a Shrine! \\ Poland! He is Thy Son! \\ Columbia! Also Thine!"32)
}

30) Speech of Dr. E. J. Scott, Washington, D. C., Oct. 18, 1926.

31) Griffin, Catholics and The Am. Rev., III, 206.

31a) Gano, History of the United States Army, p. 112.

32) Wm. K. Palmer, Poland, June, 1924. 


\section{GENERAL THADDEUS KOSCIUSZKO}

"Kosciuszko, the martyr of liberty, is no more!" exclaimed in Congress Gen. William Harrison, the ninth President of the United States, when "the American public papers announced this event which is well calculated to excite the sympathy of every American bosom!... He was remarkable, throughout his service, for all the qualities which adorn the human character. His heroic valor in the field could only be equalled by his moderation and affability in the walks of private life. He was idolized by the soldiers for his bravery, and beloved and respected by the officers for the goodness of his heart, and the great qualities of his mind.

"His fame will last as long as liberty remains upon the earth; as long as a votary offers incense upon her altar, the name of Kosciuszko will be invoked. And if, by the common consent of the world, a temple shall be erected to those who have rendered most service to mankind, if the statue of our great countryman shall occupy the place of the 'Most Worthy,' that of Kosciuszko will be found by his side, and the wreath of laurel will be entwined with the palm of virtue to adorn his brow." ${ }^{33)}$

That the love and admiration for Kosciuszko has not died out in America is attested by the recent words of the late Joseph C. Grew, Under-Secretary of State: "His name has been written in marble and bronze throughout our country, his deeds of valor in fighting for a cause which he was great enough to take as his own are written deep in the annals of history; but the true character of the man who a century and a half ago fought for the ideals which have inspired and will ever inspire the progress of Poland and the United States, is enshrined in the hearts of all of us and it is from our hearts that the call goes forth in salutation from our people to the people of Poland: Kosciuszko lives !" 34)

Many volumes could be filled with tributes paid to Kosciuszko by eminent Americans and men of other countries. It will suffice to close this with the tribute of Washington himself: "No one has a higher respect and veneration for your character than I have." ${ }^{35)}$

33) Congressional Globe, House of Repr., Jan. 20, 1818.

34) Speech at Washington, D. C., Oct. 18, 1926. There exist monuments to Kosciuszko in the following cities of the United States: Washington, D. C.; West Point and Yonkers, N. Y.; Chicago, Ill.; Milwaukee, Wis.; Cleveland, O.; Boston, Mass. Many streets and localities are named after him.

35) Sparks, Writings of Washington, vol. XI, p. 214. 
III.

GENERAL CASIMIR PULASKI 



\begin{abstract}
When Freedom raised her standard sheet, And drums the call to battle beat, When rose the din of conflict shrill From Concord field and Bunker Hill, Who heard the summons o'er the wave? Pulaski brave, Pulaski brave!1)
\end{abstract}

"In the world's solemn history Casimir Pulaski stands out like a mountain peak as a protagonist of human freedom" said the Hon. Louis Ludlow of Indiana in the Congress of the United States when the whole American nation paid homage to the hero's memory at the sesquicentennial of his death. ${ }^{2)}$

General Casimir Pulaski was another celebrated Polish commander who distinguished himself during the American Revolution. Like Kosciuszko he came here, animated only by pure idealism. Unfortunate in his endeavors to free his own Poland, he wanted to fight for the liberty of the New World.

"Honor and a true desire of distinguishing myself in defense of Liberty was the only motive which fired my breast for the cause of the United States," he writes to Col. R. H. Lee, August $13,1778,{ }^{3}$ and in his last letter to Congress, August 19, 1779, he expresses the same sentiment:- "I could not submit to stoop before the sovereigns of Europe, so I came to hazard all for the freedom of America." "4)

Forced by Russian oppression to leave Poland, Pulaski became an exile. At the first news of the American Revolution he decided to hurry to the aid of the Colonists. His French friends, Beaumarchais, Rulhiere, Vergennes and others interceded for him with Benjamin Franklin, who engaged Pulaski for the American service.

"Count Pulaski, of Poland, an officer famous throughout Europe for his bravery and conduct in defense of the liberties of his country against the three great invading powers of Russia, Austria and Prussia, will have the honor of delivering that into your Excellency's hands," wrote Franklin to Washington, May 29, 1777. ${ }^{5)}$

Washington, after interviewing him at his headquarters at Neshaminy Falls, Pa., recommended Pulaski to Congress; but the Count, unwilling to remain idle until the commission should reach him, joined the army which was at that time opposing General Howe's advance on Philadelphia. At Brandywine, Sep-

1) Wm. McDonald, Polak $w$ Ameryce, Buffalo, N. Y., March 1. 1909.

2) Remarks of Hon. Louis Ludlow of Indiana in the House of Representatives, Tuesday, June 11, 1929.

3) Griffin, Catholics and the Am. Rev., III, 67.

4) Ib., III. 104.

5) Ford's Writings of Wash., VI, 57. 


\section{POLAND AND THE AMERICAN REVOI,UTIONARY WAR}

tember 11, 1777, while still only a volunteer, he "greatly signalized himself," ${ }^{6}$ ) saving by a dashing attack with a handful of men the retreating American army from being cut off by the British, thus "fully sustaining, by his conduct and courage, the reputation for which the world had given him credit." 7)

"Casimir Pulaski rendered great and invaluable services to this country. There was a moment when by his dauntless courage, fortitude and devotion he saved the whole army of George Washington from total destruction and horrible disaster." 8)

"It was through his intelligence and activity" that the army of Washington was saved from a surprise attack of the British at Warren Tavern. ${ }^{9)}$

Congress rewarded his bravery by commissioning him, at the instance of Washington, the first commander of the American cavalry with the rank of Brigadier General, September 15, 1777. Shortly after this followed the battle of Germantown, where nearly all the cavalry had been divided for special services "so that Pulaski was left with so few men as not to have it in his power to undertake anything of importance. This was to him a matter of deep regret and bitter chagrine." 10) According to Lossing, he covered the retreat of the divisions of Greene and Stephen. ${ }^{11)}$

When Washington went into winter quarters at Valley Forge, Pulaski was sent to Trenton, N. J., with his cavalry where forage for the horses was easier to procure. There he displayed his untiring energy for the betterment of that branch of service which hitherto received little attention in the Continental Army. His many memorials and letters to Washington and Congress, preserved in the historical archives and written by him in the character of Commander of the Cavalry, reflect great credit on his talents, his patriotic zeal and his sedulous care of the soldiers. During the Winter he reorganized the existing regiments of dragoons, formed a new detachment of horse armed with the famous Polish lances - a new weapon on this continent - and this detachment he personally "undertook to train and perfect in their exercise." 12) He supplied the cavalry with its first set of service regulations and tried to inspire his soldiers with discipline and martial spirit on every occasion.

"He was an expert horseman, and not the most trivial among his contributions to the efficiency of Washington's cavalry was

6) James Lowell to Gen. Whipple, Sept. 17, 1777; Griffin, III, 11.

7) Sparks, American Biographies, 2-nd ser., vol. IV, p. 415.

8) Sermon of the Rt. Rev. Bishop M. J. Gallagher, D. D., at the R. C. Cathedral at Detroit, Oct. 11, 1929., Dz. Chicagoski, Oct. 31, 1929.

9) Wm. H. Gordon, "Count C. Pulaski," Georgia Hist. Quarterly, vol. XIII, p. 184.

10) P. Bentalou, Pulaski Vindicated, Baltimore, 1824, p. 29.

11) Field Book of the Revol., II., 318.

12) Pulaski to Washington, Nov. 23, 1777; Griffin, III, 26. 


\section{GENERAL CASIMIR PULASKI}

the knowledge of equestrianship which he imparted to it." 18) "The Count was thought to be the best and the most expert horseman in the American service." 14)

History justly conferred on Pulaski the title of the "Father of American Cavalry."

In February, 1778, he received orders to join Gen. Wayne. Their combined forces defeated the British at Haddonfield, near Camden, N. J. "Gen. Pulaski behaved with the usual bravery, having his own horse wounded," reported Wayne to Washington. ${ }^{15)}$

But conditions in the cavalry perplexed Pulaski very much. There was a steady dearth of everything. Some of the officers of higher rank were dissatisfied because they had to obey the orders of a foreigner, however distinguished. This was a common occurrence in the Revolutionary Army. Unwilling to be the cause of disharmony in the ranks, Pulaski resigned his commission of Commander of the Cavalry in March, 1778. "The character of mind and the unselfishness which actuated his service in our cause, his willingness to make every personal sacrifice for the cause that aroused his enthusiasm and support, is best evidenced by his voluntary resignation of the command of the cavalry of the Continental Army in order that misunderstanding and lack of harmony among certain officers might not exist." 16)

Having returned to Valley Forge, Pulaski presented to Washington a plan of raising an independent corps, consisting of 68 cavalrymen and 200 infantrymen. Washington accepted the plan and recommended it to Congress. "Count's valor and active zeal on all occasions have done him great honor," wrote the General to Congress at that time. ${ }^{17)}$

On March 19th, Congress sanctioned the formation of the corps which is known in history as the celebrated Pulaski Legion. The officers of the Legion were mostly Frenchmen, Germans and Poles, and the soldiers mostly American Germans. It was one of the few detachments of the Revolutionary Army predominantly foreign in its composition.

During the recruiting of the Legion, Pulaski visited Bethlehem, Pa., where he ordered from the Moravian Nuns a banner for his Legion. This incident served as a theme for Longfellow's beautiful and well-known poem. For this banner, now preserved by the Maryland Historical Society of Baltimore, Pulaski paid out of his own funds just as he gladly bore many other costs of 1929.

13) J. Gurn, "Why We Honor Gen. Casimir Pulaski," Columbia, Oct.

14) Eager, History of Orange Co., N. Y., p. 337.

15) Griffin, III., 53.

16) Statement of Hon. John W. McCormack. Hearing before the Committee on the Judiciary. H. R. 71-st Congress, 2-nd Session, May 17, 1930 .

17) Griffin, III, 56. 


\section{POLAND AND THE AMERICAN REVOLUTIONARY WAR}

the equipment and sustenance of his beloved Legion. Captain Baldeski, paymaster of the Legion, stated that "Count Pulaski has laid out for the Legion at least $\$ 50,000$ of his own money" without any expectation of a refund ${ }^{18)}$ and Pulaski himself at another time informed Congress, September 17, 1778, that he expended at least sixteen thousand dollars of his own for his soldiers. When pressed by Congress for vouchers lost by the officers during the marches and battles of the Legion, $\mathrm{Pu}-$ laski declared with a truly magnanimous gesture that he expected to receive 100,000 livres from Europe, and the "pleasure to me will be surely great to repay you to the utmost farthing the whole charge of my Legion." 19)

By the end of September, 1778, Washington sent Pulaski to New Jersey, where through the treason of a Hessian deserter the infantry of the Legion was surprised by 400 British under Capt. Ferguson at Egg Harbor, Oct. 15, and 30 legionaries were lost, among whom was the commander of the infantry, Col. Baron de Botzen, a Pole. Pulaski with the cavalry came to the rescue and forced Ferguson to flight with heavy losses.

The winter of 1778-1779 Pulaski spent in the northwestern part of New Jersey, where he guarded the frontiers from the depredations of Indians and Tories. On February 2, 1779, Congress resolved that "Count Pulaski be ordered to march with his Legion to South Carolina and put himself under the command of Gen. Lincoln."

Having strengthened the Legion with new recruits, he set out on his way in Spring and "reached Charleston, S. C., at the very time when the British General Prevost, having suddenly and rapidly advanced from Savannah, appeared before that city, on the 14th of May, 1779, in the confident expectation that it would surrender to him on the first summons. The unlooked for arrival of Pulaski baffled his hopes. Already had the Governor and Council agreed on terms of capitulation, not the most honorable, when General Pulaski, accompanied by the brave Colonel Laurens, repaired to the Council chamber to protest against that precipitate measure, declaring that, as a Continental officer, he would defend the city for the United States. Prevost was informed of that determination. Pulaski saw the necessity of reviving the drooping spirits of the inhabitants. Accordingly he sallied on with the Legion." 20 ) His infantry "from an eagerness to engage" frustrated his plan of ambuscade, showing themselves to the British too soon. "Pulaski, however, by discovering the greatest intrepidity, and by successful personal encounters with individuals of the British cavalry, had considerable influ-

18) Saffell, Records of the Rev. War, p. p. 30-36.

19) A. F. Zaleski, "Hero of Two Continents," Poland, X, 661.

20) Bentalou, Pulaski Vindicated, p. 31. 


\section{GENERAL CASIMIR PULASKI}

ence in dispelling the general panic and introducing military sentiments into the minds of the citizens." 21 ) city. ${ }^{22)}$

This sortie of Pulaski caused Prevost to retire from the

"From the moment that the British forces started their retreat from the attempt to capture Charleston until their arrival in Savannah, Pulaski, although suffering from frequent attacks of climate fever, pursued the enemy, dealing them a blow whenever possible." 23 )

He displayed the same energy during the siege of Savannah by Gen. Lincoln and Count D'Estaing. In the ill-fated assault upon the city, October 9, 1779, Pulaski was wounded in the tigh by a grape shot when trying to arrest the retreat of the French columns. Writers, however, differ about the details of his last service to the American cause.

"Awful the scene! fierce horror stalk'd around,

Six hundred French lay gasping on the ground;

Of freedom's sons, two hundred bravely slain,

And fierce Pulaski bit the ensanguin'd plain." ${ }^{24}$

Two days later he died on board of the ship Wasp. The wound, though probably not mortal in itself, became infected and gangrenous. His death is to be attributed to the undeveloped state of surgery at that time rather than to the seriousness of the wound.

His companions "consigned his corps to a watery grave." His death was lamented universally by the patriots of the Revolution. Grateful Americans paid their tribute to him in various ways, and only recently President Hoover proclaimed October 11,1929 , the 150th anniversary of his death, and again October 11, 1931, the 152nd anniversary, Pulaski Memorial Days. ${ }^{24 a)}$

"Columbia! He died for thee-

Cheerfully - and for Liberty!

Honored forevermore-

On this Atlantic shore

Palms for Pulaski! Palms!" ${ }^{25)}$

21) Wm. Gordon, The History of the Rise, Progress and Establishment of the Independence of the United States, London, 1788, vol. III, p. 257.

22) Wm. H. Gordon, "Count Casimir Pulaski," Georgia Historical Quarterly, vol. XIII, p. 200.

23) Hon. John W. McCormack before the Committee on the Judiciary, H. R., 71-st Congress, 2-nd Session, May 17, 1930.

24) Richard Snowden, Columbiad, Canto XI, Baltimore, 1800.

24a) A Pulaski commemorative stamp has been issued by the Government of the United States on occasion of the Sesquicentennial of his death. Many American counties, towns and villages and streets in many cities bear his name. The following cities have Pulaski monuments: Savannah, Ga.; Washington, D. C.; Milwaukee and Stevens Point, Wis.; Chelsea, Mass.; Utica, N. Y., and still others. Baltimore, Md., is erecting one.

25) Wm. K. Palmer, Poland, June, 1924. 


\section{POLAND AND THE AMERICAN REVOLUTIONARY WAR}

Pulaski's distinguished biographer, Jared Spared, thus estimates his character and services:

"Pulaski in his private qualities seems to have been amiable, gentle, conciliating, candid, sincere, generous to his enemies and devoted to his friends... His soldiers adhered to him as to a brother, and willingly endured fatigues and encountered perils, the most appalling, when encouraged by his approbation or led by his example. He possessed in a remarkable degree the power of winning and controlling men... Energetic, vigilant, untiring in the pursuit of an object, fearless, fertile in resources, calm in danger, resolute and persevering under discouragements, he was always prepared for event and capable of effecting his purposes with the best chance of success. He was true to his principles and firm in maintaining them. An ardent attachment to the country and to her liberties, and the hope of rescuing her from the thraldom of despotic rule, were the motives which roused his indignant spirit, animated his zeal and nerved his arm in battle till the freedom of Poland has expired in the grasp of powerful and perfidious oppressors.

"During his short career in America, we perceive the same traits of character and the same steady principles of action. That he gained and preserved the friendship of Washington, who more than once in a public manner commended his military talents, his disinterestedness and zeal, is a sufficient proof of his merits as an officer, and his conduct as a man. His activity was unceasing, and his courage was conspicuous on every occasion in which he had an opportunity to meet the enemy. He embraced our cause as his own, harmonizing as it did with his principles and all the noble impulses of his nature. He lost his life defending it, thus acquiring the highest of all claims to the nation's remembrance and gratitude." ${ }^{26)}$

26) Am. Biographies, 2-nd ser., vol. IV, p. 444. 


\section{IV. \\ OTHER POLES IN THE REVOLUTIONARY ARMY}



Besides Kosciuszko and Pulaski Poland gave the American Revolutionary army scores of other soldiers who, though less renowned, also deserve to be held in grateful memory because their labors and blood helped to win the independence of the United States.

They may be roughly divided into two groups. To one of these groups belong those who came to America during the Revolution with the sole purpose of fighting on the side of the ideals of liberty and justice. It was, therefore, a war immigration, mostly temporary. The other group is composed of those Poles, or rather Americans of Polish extraction, who lived in America before the war, in some cases for several generations. For, contrary to common opinion, the Polish immigration in the United States is as old, as the English speaking colonies themselves, though it never was very numerous up to middle of the last century.

In his search for the names of Poles in the Revolutionary War the author encountered difficulties which are inseparable from this kind of historical work. First of all, the collection of all such names is impossible. Notwithstanding that a century and half has passed since the Revolution, the registers of Revolutionary soldiers are full of omissions and inaccuracies, - a fault which in many cases can never be corrected. Many soldiers enlisted for a brief term, many reenlisted, sometimes more than once; therefore the composition of various militias, and even of the Continental Army changed continually. Records were kept carelessly in most cases, many of them were destroyed. Even the best registers extant are not without inevitable errors.

The other difficulty is that of identifying the Poles among the thousands of the Revolutionary soldiers. In this respect the author was governed almost entirely by the sound or spelling of the names. There are many objections to this method, but it was the only one possible. The Revolutionary records only very seldom give the country of birth and nationality of the soldiers. Even if they were recorded, it would be valueless in cases of the old Polish colonial immigration, for instance: the families of Sanduskys and Zabriskies. An additional difficulty is the great instability of spelling of names in the Revolutionary documents. The same names are written very differently, sometimes in twenty and more variations.

This concerns especially the second group of Poles, - the Polish colonial immigration. The long abode among a people, foreign to them, caused their names to lose much of their Polish character and, in some cases, wiped it out completely. The descendants of the Poles appear under Anglicized names or dis- 


\section{POLAND AND THE AMERICAN REVOLUTIONARY WAR}

figured to such an extent, that their Polish origin can be discovered only with difficulty.

Two kinds of American Revolutionary forces - the Continental Army and militias - should be distinguished in relating the part which the Poles played in the war of 1775-83. The Polish war immigration served without exception in the Continental Army. This was because there was no place in militias for foreign professional soldiers. Militias offered to them no chance of steady service nor of gaining a higher rank.

Polish colonial immigrants, bearing the burdens of war together with their American co-citizens, appear as well in the militias as in the Continental Army - mostly as privates in both forces.

The fortunes of nearly all the Polish Revolutionary soldiers of the war immigration were associated with those of Pulaski. Kosciuszko served throughout the whole war with only occasionally and for the most part only privately meeting his countrymen. He was an engineer, commanding only a few officers and a handful of soldiers and workmen. He could not, therefore, even if he wished, secure commissions under himself for his countrymen, especially as all of them were officers of the line. Pulaski, however, was always surrounded by his compatriots; they came to him lured not only by his already well established fame, but also by his independent position of Commander of Cavalry, or later Commander of his Legion; this allowed him to propose subaltern officers to Washington and Congress for commissions.

Thus when a Pole came from Europe to enlist with the American army, he hurried to Pulaski's quarters, where he was sure of a brotherly reception. But it was not easy to reach America, especially after the first year of the war. American representatives in Paris rather discouraged than encouraged volunteers. Of all the Poles only Pulaski and Kotkowski came to America with letters of recommendation from Franklin and Deane, others came without them, probably at their own risk and at their own cost.

The following registers contain the names of all those whose Polish nationality is certain and also those regarding whose nationality there exists no direct evidence, but who appear to be Poles.

The Poles or supposed Poles of the war immigration were:

\section{BALDESKI, JOSEPH}

A Captain who served as paymaster of the Pulaski Legion. Appears in the documents also as Baldesque and Baldesqui. Heitman gives the following record of his service: - commissioned May 10, 1778, resigned December 29, 1779, but he does not know his nationality. ${ }^{1)}$ No document known to the author

1) F. B. Heitman, Historical Register of Officers of the Continental Army during the War of the Revolution, Wash., 1914, p. 82.

36 


\section{OTHER POLES IN THE REVOLUTIONARY ARMY}

explains this question. Baldeski himself in a letter to Congress says that he served in the French army before coming to America and is here a foreigner. ${ }^{2)}$ One of the variations of his nameBaldeski, may point to his Polish nationality, though, in this case, its proper spelling should be Beldowski or Beltowski. Pulaski's name was spelled also Polasque in some of the documents.

Capt. Baldeski figured prominently in the settlement of the accounts of the Pulaski Legion by Congress. Some of the vouchers for money paid out by the Legion for materials were lost during the marches and battles. The auditors of Congress refused to approve the accounts without them. They also questioned some of the payments, and their attitude toward Capt. Baldeski and Gen. Pulaski in this affair, was, indeed, too severe. Pulaski not without a good cause, as it would appear from the documents, complained of it more than once in his letters. When the Legion left for the South, early in 1779, Capt. Baldeski was kept by Congress in Philadelphia until the accounts were settled. The incident does not reflect on his character in any way. He appears to be an honest officer, though perhaps somewhat careless or rather, as an officer of the line, not well acquainted with the methods of keeping accounts. He defended his commander, Pulaski, with dignity against any possible suspicion as to his integrity, and Pulaski, reciprocally, assured Congress on many occasions of Baldeski's honesty.

Because of some private business, Baldeski left Philadelphia for Boston during this inquest. There he fell ill and could not return to Philadelphia on time. It caused some gossip among the members of Congress which reflected on his character. Captain Baldeski then resigned in disgust.

What were his whereabouts after the war?

Townsend Ward in his recollections of the old Germantown, Pa., ${ }^{3)}$ says that at the end of the 18-th century there stood on Main St. a small and queer looking house occupied by a certain Count Baldusky. The Count earned his livelihood by a quite prosaic occupation of making starch. His manner of living corresponded with his fallen fortune, but there was woven about it something of the aristocratic elegance. The inhabitants considered him a whimsical man. It happened once that Count Baldusky fell sick and called Dr. Bensell, the local physician, known in the community as a coward. The doctor found him in his bed covered with a wornout but silken bed-cover, a remnant of his better days. The only other luxurious thing in the room was a small-sword hanging on the wall over the bed. The physician examined the patient and decided that letting of blood was necessary. The Count agreed, but taking the sword from the wall threatened

2) W. T. R. Saffell, Records of the Revolutionary War, N. Y., 1858, p. p. $32-36$.

3) Penna. Magazine of History and Biography, vol. VI. p. 267. 


\section{POLAND AND THE AMERICAN REVOLUTIONARY WAR}

to kill the doctor should one drop of blood fall upon the bed-cover. Dr. Bensell did such an awkward job that the first stream of blood put out the candle held by the only servant of the Count. Frightened, the physician fled. The Count started after him, but in the darkness came across the servant and both fell. Count Baldusky regained his health and this anecdote is the only recollection of his stay in Germantown.

Ward calls him "a French emigrant," but this cannot be taken as a final proof of the nationality of the Count. Traditions are sometimes misleading. The name Baldusky suggests rather that the extravagant Count was a Pole and that it was a misspelled form of a Polish name.

The question suggests itself whether Count Baldusky of Germantown and Captain Baldeski of the Pulaski Legion were one and the same person.

In fact, Count Baldusky of Germantown is entered in the first census of the United States, in 1790, as Joseph Baldeskie. This confirms the above supposition as to the identity of Count Baldusky with Capt. Joseph Baldeski, and strengthens the supposition as to his Polish nationality; the entry of the name in the census being probably spelled in the manner in which the Captain used it in America.

According to the first census, the household of Captain Baldeski consisted of three white male persons over sixteen years old and three white females, which does not agree with the anecdote of Ward, but, undoubtedly, deserves more credence. ${ }^{3 a}$

\section{BENIOWSKI, MAURICE AUGUST}

This is the famous adventurer, the author of well known memoirs.

Born in Hungary, in 1741, of a family connected with Poland by blood and history, Beniowski early emigrated to Poland and took part in the first Polish war for freedom, the Confederacy of Bar. Captured by the Russians, in 1769, he was exiled to Kamchatka with many other Polish prisoners of war. There he gained the confidence of the Governor and the affection of his daughter; with her help he headed his companions of exile in the capture of a large and well provisioned ship and escaped. They reached France in 1772. He later induced the French Government to send him with an expedition to Madagaskar, where he won the confidence of the natives to such a degree, that they made him their king. Disagreeing later with the French administration, he left the island and returned to France, took part in the war for Bavarian succession as Colonel of Austrian Hussars and resided for some time in Hungary. He interested the

3a) Dept. of Commerce and Labor, Bureau of the Census, Heads of Families at the First Census of the U. S., Wash., 1907; Penna., 196. 


\section{OTHER POLES IN THE REVOLUTIONARY ARMY}

Austrian Government in a scheme for developing the trade of Fiume; but when the plan collapsed, he decided to go to America.

From his memorial to the Continental Congress of June 20, 1780, we learn what happened to him thereafter:

"At the beginning of the war between America and Great Britain your memorialist embarked a vessel sailing for America to join the army of this country, but he had the misfortune to fall into the hands of enemies and was imprisoned for a long time in Portsmouth, whence, at last, he escaped. But soon, when he was going to America, he was imprisoned again and brought to Plymouth, whence he also escaped; and when he persisted in his intentions he was arrested for the third time. Thanks to the intervention of Count d'Almadovar he regained his freedom, but lost everything he had. At last he came to America where he immediately joined the detachment, commanded by Gen. Count Pulaski. He hoped that doing with him the duties of a brave officer he would receive a commission in the army with his help, as Count Pulaski was his near relative. But a few days after he reached the Legion, the greatest of all misfortunes befell him the General fell in the attack at Savannah beside your memorialist and with him fell the only friend your memorialist had in America."

The earliest date on which Beniowski's name appears in the papers of the Continental Congress, is September 4, 1779. On that day the Board of War reported to Congress "that they have conversed with a gentleman stiling himself le Baron de Benyowsky who has a letter directed to General Pulaski, who he says is his half brother and he now desires only the means of going to him." Congress resolved "that Mons. le Baron de Benyowsky be supplied with a horse and one thousand dollars, to enable him to proceed to General Pulaski, now with the southern army." 4)

At that time Pulaski was already at Savannah where he fell October 9,1779 . Beniowski could reach him only a few days before that fatal date, and, perhaps, found him already on his death-bed. This, at least, may be supposed from what Dr. P. Fayssoux, Surgeon General of the State of South Carolina, told Joseph Johnson, the author of Traditions and Reminiscences. Dr. Fayssoux, according to Johnson, being well acquainted with the particulars concerning the death of Pulaski, reported that the hero "had the consolation of being attended in his last hours by a countryman-a relative, a friend,-a brother Confederate in the cause of their native country. Count Benyowsky was recognized by the dying hero, officiated as his relative, chief mourner and heir, and departed." ${ }^{5)}$

4) M. I. J. Griffin, Catholics and The Am. Rev. War, vol. III., p. 105.

5) J. Johnson, Traditions and Reminiscences chiefly of the Am. Rev. in the South, Charleston, 1852 , p. 246. 


\section{POLAND AND THE AMERICAN REVOLUTIONARY WAR}

Beniowski then returned to Philadelphia and presented to Congress a new memorial, December 20, 1779, asking for a commission in the Continental Army, but Congress declined the offer, resolving that "the circumstances of the army will not admit of his being employed." 6)

Beniowski found himself now in dire straits. He was a stranger in a country, whose language he did not know, without friends and financial means. It is not known what he did in the meantime. The next document pertaining to him is his new memorial to Congress of June 20, 1780, in which he describes his distress and asks for permission to join the army of Washington as a volunteer to show that he deserves a commission. The answer of Congress to this memorial is unknown. It is also unknown what he did thereafter. But his friendship with Gen. Baron de Steuben admits the supposition that his wish was granted and that he served with him as a volunteer.

All the documentary traces of Beniowski disappear again until March 28, 1782. Under that date he wrote to Washington through Baron de Steuben:

"I offer to your country, whose citizen I want to be, - my blood, my knowledge and my bravery. If my proposition is accepted, I ask you a favor that I may make the next campaign under your command and at your side; maybe the favoring circumstances will allow me to justify the respect and confidence with which you will honor me. You have honored with your confidence my cousin Pulaski; be kind to transfer it to me; my zeal and attachment will justify your goodness."

The proposition which Beniowski mentioned in the above paragraph and which he sent to the Commander-in-Chief together with a letter, consisted of fifteen articles and was a plan to raise a Legionary Corps of Germans for the service of the United States which Beniowski agreed to "raise, cloath, arm, equip and transport" from Germany to America for the consideration of 518,000 livres (about 100,000 dol.). The Legion was to consist of 3,483 officers and men of all kinds of arms.

Washington promptly replied to the proposition. He wrote to Gen. de Steuben from Newburgh, April 12, $1782: 7)$

"Dear Baron:-The proposition of Count Beniowski which you put into my Hands for Consideration, I have read, and beg leave to observe thereupon, That the Utility of his plan for introducing a Legionary Corps of Germans into the Service of the United States of America, depends in my opinion, upon the political State of Affairs in Europe - the Probability of the War's continuing, and the mode of conducting it-as also on the time which will be required to bring the Corps into Action. -

6) Papers of the Cont. Congress, No. 78, III, 415.

7) The original draft of Gen. Washington's letter is in the possession of Dr. A. Kahanowicz of Detroit. Mich., from which the above was copied. 


\section{OTHER POLES IN THE REVOLUTIONARY ARMY}

"Of the first, I have not the means of Judging,-but I think the second is not so problematical as to induce Congress to reject a Contract, which with some Alterations, and a surety of receiving the Men in twelve months from this Date, may be attended with considerable advantages."

The rest of the letter contains the remarks of Washington on Count Beniowski's plan which he endorsed with some changes, considering the expense of 518,000 livres "moderate indeed."

Beniowski's plan was referred to the Board of War who also endorsed it, but on June 1, 1782, Congress decided to decline the proposals. Meanwhile Beniowski laid his plan before James Madison and Theodorick Bland, delegates to Congress from Virginia, in the hope of gaining their support, ${ }^{8)}$ but with no result. The hopes for peace were stronger and the probability of renewed action on land diminished day after day, and this influenced Congress to reject the offer.

This ends the activity of Beniowski in America during the Revolutionary War. Disappointed in his hope to serve the American cause, he left for Europe shortly after.

Just before his departure he wrote to Gen. Steuben from Philadelphia, June 15, 1782:

"I will write to Gen. Washington to wish him everything good from all my heart. I have no reason to complain against him. On the contrary, I have experienced the greatest kindness from him. I am much attached to him out of gratitude, just as I am to you, my dear friend." He was evidently personally acquainted with Mrs. Washington since in one of his letters to Washington he asked him to "express his respects to his Lady."

Beniowski returned to France and tried to induce Count Vergennes, the French Minister of Foreign Affairs, to accept his scheme for the colonization of Madagaskar. Having met with a cold reception on the part of the Minister, he returned to America in 1784, and in October sailed with an American ship the Intrepid for that island. There he tried to overthrow the French authorities, but was killed in an encounter with French troops, May 23, 1786.9)

Though not a Pole by birth, Beniowski considered himself rather a Pole than a Hungarian. During his exile in Siberia he adopted the characteristic name, August the Pole. He became the popular hero of Polish literature; Julius Slowacki, one of the famous trio of geniuses of Polish romantic poetry, immortalized his name in one of his finest poems. "His temperament," says one of his Polish biographers, 10) "the course of his whole life, his service for the Polish national cause together with two of its most eminent exponents, Pulaski and Father Mark, - make

8) Spark's Transcripts, Virginia State Library, I, 173-183.

9) S. P. Oliver, Memoirs of Benyowsky, London, 1904, Foreword.

10) A. Potocki, Dziennik Podróży Beniowskiego, Cracow, 1898, I, 4. 


\section{POLAND AND THE AMERICAN REVOLUTIONARY WAR}

Beniowski the true son of his epoch and of the Polish nation, which adopted him as its own." 11$)$

\section{DE BOTZEN (DE BOZE), BARON-}

His first name is unknown. The one variation of his name appears as frequently as the other. Heitman's Register does not give his nationality, but contains the following service record: Lieutenant-Colonel, Pulaski Legion, killed at Egg Harbor, October 15, 1778. ${ }^{12)}$

The name of Baron De Botzen, or De Boze, is not Polish. William Abbatt, however, calls him a Pole. ${ }^{13)}$ Thomas Balch mentions him among the officers of the French army who served in the Revolutionary War, and adds: "Polish lieutenant-colonel in the service of the Americans in the Legion of Pulaski." 14) Balch's testimony as to the nationality of De Botzen may be considered especially valuable as he made personal researches into the French official documents at Paris. Polish heraldry books do not mention the name of De Botzen, but it is possible that it was an assumed name. The title of Baron may also be assumed, as, for instance, in the case of Gen. Baron De Kalb who was only of humble origin.

The particulars of the military career of Baron De Botzen in America are very meager. It is known that he commanded the infantry of the Legion. Bentalou ${ }^{15}$ mentions him in the narrative of the battle at Egg Harbor. Among the subordinates of De Botzen was a German deserter, Jullien. De Botzen's "high sense of honor"-says Bentalou, who knew him personally, was the cause of his contempt for an officer who deserted his flag. $\mathrm{He}$, therefore, treated him with no respect. Jullien, moved by a desire of revenge, deserted again and induced the British Captain Ferguson to attack the camp of Pulaski at Egg Harbor by surprise.

The enemy, led by Jullien, landed his troops under cover of night and reached the quarters of the Legion's infantry before sunrise. At the first alarm, De Botzen ran out from the house where he slept, armed with saber and pistols; but though he was of unusual strength and fought "like a lion," he was overpowered and fell dead. According to Bentalou, De Botzen seemed to have been the chief aim of the attackers. Jullien was heard shouting: "That is the Colonel, kill him!" His whole body was

11) The sketch of Beniowski's career in America is mostly founded upon the very good monography of Prof. W. M. Kozlowski, "Beniowski w Ameryce," Bibljoteka Warszawska, 1903, vol. II, p. p. 155-170.

12) Heitman's Register, p. 191.

13) Magazine of History, Extra No. 8, "Pulaski Vindicated," p. 4.

14) Thomas Balch, The French in America during the War of Independence, vol. II, p. 59.

15) P. Bentalou, A Reply to Judge Johnson's Remarks, Baltimore, 1826. 


\section{OTHER POLES IN THE REVOLUTIONARY ARMY}

covered with bayonet wounds. It is probable that he was not cautious enough, but he died a real soldier's death.

\section{ELHOLM, AUGUST CHRISTIAN GEORGE}

The above named officer is treated in a separate chapter of this book.

$$
\text { JERZMANOWSKI- }{ }^{16)}
$$

First name and rank unknown. No Revolutionary document known to the author, nor Heitman's Register contains his name. $\mathrm{He}$ is mentioned in The Remnants of the Memoirs of Matthias Rogowski, 17) who, according to that source, was a friend of $\mathrm{Pu}$ laski and an officer of his cavalry. Boleslawita in Rachunki $z$ $r .1867$ also mentions him. ${ }^{18)}$ Rogowski says that Jerzmanowski was sent to Pulaski's cavalry by Washington:- "The young and brave man brought us latest news from Poland and performed his duties with zeal doing picket duty and reconnoitering; because of this Pulaski liked him and predicted that he would be a great soldier."

The memoir mentions him again as present in action at Charleston and Savannah. When Pulaski fell from his horse in the attack at Savannah "our good soldiers, encouraged by Jerzmanowski, though retiring, carried Pulaski, myself and other wounded men off the field, notwithstanding the dense fire of the enemy," says Rogowski.

Taking the authenticity of the Remnants for granted, it is possible, that Jerzmanowski served under Pulaski as a volunteer without rank, and this would explain the absence of his name in the documents.

\section{KOTKOWSKI-19)}

First name unknown. The family name appears in the documents as: Kolkauski, Katskoetski, etc. Heitman gives the following service record: - Kolkauski - Count, (Poland), Captain Pulaski Legion, commissioned December 10, 1778, to-.

Kotkowski was an officer in the Polish Confederacy of Bar, the national movement against the Russian oppression of which Gen. Casimir Pulaski was one of the leaders. Polish heraldry books mention one noble family of Kotkowski, using the coat of arms Ostoja; some branches of this family use variations of the name:- Chutkowski and Kutkowski.

After the fall of the Confederacy Kotkowski probably went into exile with Gen. Pulaski and together with him wandered

16) Pronounced Yeshmanofsky.

17) Paris, 1847. The question of the authenticity of the memoirs of Rogowski is discussed under that name.

18) Poznan, 1868, II, 90; report concerning the American Poles by Dr. Henry Kalussowski of Washington, D. C.

19) Pronounced Kotkofsky. 


\section{POLAND AND THE AMERICAN REVOLUTIONARY WAR}

about Europe until they found refuge in France. In 1776 he called on Silas Deane, the American Commissioner at Paris, to offer his services to the American cause. Because of too many volunteers he, like Pulaski, had to wait long for a final answer from the Americans. Some prominent Frenchmen interceded in his behalf, among whom must have been also the historian Rulhiere who conducted negotiations with Franklin in behalf of Pulaski, - and Kotkowski was engaged with the approval of not only the credulous Deane, but also with that of the cautious Franklin. The American Commissioners did not promise him a rank, but gave him very favorable letters of recommendation and facilitated his voyage to America. It was very much, indeed, if we remember that Franklin declined on principle the offers of foreign volunteers and only seldom deviated from this rule.

Franklin wrote to Washington from Paris, June 13, 1777:

"Sir:-The bearer, M. le Comte Kotkowski, a Polish officer, is recommended to me by several persons of worth here, as a man of experience in military affairs, and of tried bravery. $\mathrm{He}$ has lost his family and estate in Poland, by fighting there in the cause of Liberty, and wishes, by engaging in the same cause, to find a new country and new friends in America. Count Pulaski, who was a General in the Confederates in Poland, and who is gone to join you, is esteemed one of the greatest officers in Europe. $\mathrm{He}$ can give you the character of this M. Kotkowski, who served under him as a Lieutenant-Colonel.

"It is with regret that I give letters of introduction to foreign officers, fearing that you may be troubled with more than you can provide for, or employ to their and your own satisfaction. When particular cases seem to have a claim to such letters, I hope you will excuse my taking the liberty. I give no expectations to those who apply for them; I promise nothing; I acquaint them, that their being placed when they arrive is a great uncertainty, and that the voyage being long, expensive, and hazardous, I counsel them not to undertake it. This honest gentleman's zeal is not to be discouraged by such means; he determines to go and to serve as a volunteer, if he cannot be employed immediately as an officer; but I wish and hope, that your Excellency may find a better situation for him, and that he will be a useful officer. He has the advantage of understanding English, and will soon speak it intelligibly. He also speaks German, and some other European languages, and the Latin." ${ }^{20)}$

Deane also gave him a very favorable letter. It is dated June 14 , and addressed to Washington. Deane calls him "Koskoutski" and also mentions that he suffered much for the cause of freedom in Poland. ${ }^{21)}$

20) J. Sparks, Works of Benj. Franklin, Boston, 1839, vol. VIII, p. 220.

21) Papers of the Cont. Cong., 103, 79. 


\section{OTHER POLES IN THE REVOLUTIONARY ARMY}

Notwithstanding the secrecy of the work of the American Commissioners, Lord Stormont, the British Ambassador in Paris, knew perfectly well what was going on in the opposite camp. He informed his government in July, 1777, that among the new officers sent to America is "M. Katskoetski - no rank, but has recommendations." 22 )

The first mention of Kotkowski's presence in America appears, however, not until the Fall of 1778 . It is not known what he was doing in the meantime. Evidently, something must have happened which unexpectedly kept him from leaving France for over a year. A letter of recommendation from Commodore Abraham Whipple to Gen. John Sullivan of the Continental Army given to Kotkowski under the date of Boston, October 9th, 1778, mentions his arrival in Boston as a rather recent occurrence: "The Count having arrived as a passenger in Capt. Tucker of the Boston at first gave me an opportunity of knowing his public Credentials, and induces me thus far to this introduction which I flatter myself will be agreeable to both."22a)

With this letter Kotkowski left Boston for Providence, R. I., where Gen. Sullivan was then stationed. But Sullivan could employ him in no capacity and, having favored him with a new letter of recommendation, directed him to Henry Laurens, then President of the Continental Congress. ${ }^{22 b}$ )

Laurens, in turn sent the wandering Polish Lieutenant Colonel to General Pulaski, then in New Jersey. Pulaski, at last, referred him to Washington, having added a new recommendation to the already numerous introductory letters of Kotkowski. $\mathrm{Pu}$ laski's letter is dated Sussex Court House, N. J., November 15, 1778 , and says in part:

"I have the honor to present to you one of my countrymen, Mr. Kotkowski. He served in Poland in one of my divisions and I know him as a brave and useful officer for the American service. I request that he may be placed in the Legion with the rank of Captain and pay of a Lieutenant and to do the duty of the last one until he finds an opportunity to show his talents and get another position." ${ }^{23)}$

After a personal interview with Kotkowski, Washington wrote to Pulaski, November 24:- "I gave Count Kolkowstki a letter to Congress in which I communicated your request." 24)

The recommendation of Washington brought a favorable result. Congress commissioned him Captain of the Legion, December 10,1778 .

22) Stevens, Facsimiles, No. 176.

22a) O. G. Hammond, "Letters of Maj. Gen. John Sullivan," Collections of the New Hampshire Hist. Soc., vol. II, p. 412.

22b) Ib. vol. II, p. 419.

23) Letters to Washington, XXIX, 4.

24) Letters, B, VII, 104. 


\section{POLAND AND THE AMERICAN REVOLUTIONARY WAR}

The Legion was then at Minisink, N. J., on the Delaware, whither it had been sent by order of Washington to protect the frontiers from the attacks of the Tories and Indians. An expedition was planned against them under Gen. Hand. Pulaski prepared himself for it and Capt. Kotkowski took part in these activities.

But in the beginning of January, 1779 , something happened which ended unfortunately for Kotkowski. He was cited before a court - martial by Gen. Hand accused of "rebellious" behavior at the house of Daniel Westfall in Minisink, January 9. The court convened two days later. ${ }^{25)}$ Its records are not clear enough as to the cause of the proceedings. The depositions of witnesses do not show what was the "rebellious" behavior. Capt. Frey of the Legion, a Frenchman, who also served with Pulaski in Poland, said that Mr. and Mrs. Westfall came to him in the evening crying and complained that Capt. Kotkowski wanted to kill everybody in the house. Frey went to the house and began to reproach Kotkowski to which he answered that Westfall is a villain. Frey reminded him that he was not in Poland, whereupon Kotkowski drew his sword, but was disarmed. Westfall testified that Kotkowski came to his house with a handful of soldiers and looked for something in the rooms with drawn sword, overturning chairs, then went to the cellar and ordered the soldiers to break the door to it. The testimony of the soldiers purported to be the same, but also does not disclose the purpose of the search or the cause of the anger. ${ }^{26)}$

Despite the lack of clearness in the case the court-martial found Kotkowski guilty and sentenced him to be discharged from the army. Not waiting for further developments he went to Washington and asked him for dismission, which was granted.

All traces of Kotkowski in America disappear now forever. He probably returned to Europe soon after these events.

It should be said in his favor that the whole affair at Minisink might have been the outcome of a misunderstanding. Kotkowski was not long enough in America to master the English language and to familiarize himself with the spirit and customs of the people. This was the common cause of many disagreeable incidents to other European volunteers in the Revolutionary Army. It should be further remembered that it was the time of Valley Forge, when the forces suffered the greatest want, and the people were always very sensitive to all sacrifices for the army. The slightest transgressions of what they considered their rights caused loud protests and dissatisfaction. It was for this reason that Washington never dared to enforce his confiscatory powers. And if the Whigs were so irritable what of

25) Letters to Washington, $\mathrm{XXX}, 39$. 1905.

26) W. M. Kozlowski, "Pułaski w Ameryce," Bibljoteka Warszawska, 


\section{OTHER POLES IN THE REVOLUTIONARY ARMY}

the Tories who crowded New Jersey, New York, Pennsylvania and other colonies? Pulaski, Armand and other commanders suffered much from them. The enmity of the Tories was especially strong against all foreigners. Therefore it is possible that Kotkowski was the victim of all these combined circumstances.

$\mathrm{Be}$ this as it may, Kotkowski was the only Pole who was dismissed from the Revolutionary Army. No one could deny that he came over with the best intention to serve the American cause. If he transgressed the rules and orders in some matter, we must remember that to err is human.

\section{KOWACZ, MICHAEL ${ }^{27)}$}

Colonel of the Pulaski Legion. Dr. Johnson in his Traditions and Reminiscences of the Revolution ${ }^{28)}$ expresses a supposition that he was a Hungarian. No Revolutionary document known to the author mentions his nationality, but Heitman's Official Register of Officers says of him:- Kowatz Michael de, of Poland, Colonel commandant, Pulaski Lancers of Pulaski Legion, commissioned April 18, 1778, killed before Charleston, May 11, 1779.29)

The suffix "de" shows that Col. Kowacz was of noble origin or, at least, passed as a noble. Pulaski usually added it to his name in his correspondence.

Kowacz was an old officer of the Prussian army. The diaries of the Moravians of Bethlehem, Pa., call him "a Prussian officer of Hussars who had long been living in retirement." ${ }^{30}$ ) Johnson characterizes him as "an officer of great merit and experience, who had been Colonel of the Hussars, under Frederick the Great, from whom he received the Cross of Merit." 31) Pulaski presented him to Washington also as a former Prussian officer who served in the Seven Years War.

The Prussian service of Kowacz has no relation to his nationality; it was then a common custom for professional soldiers to serve in foreign armies.

When and how Kowacz came to America is not known. He is first mentioned in the documents in December, 1777, when $\mathrm{Pu-}$ laski proposed to Washington, then in Valley Forge, to engage him as "Master of Exercises" for his cavalry. ${ }^{32}$ )

From his winter quarters at Trenton, N. J., Pulaski again wrote to Washington in this matter, January 8, 1778:-

"I have the honor to assure your Excelly. that the Cavalry is in want of every article. It must be exercised and taught the service from the Colonel to the private. Col Kovatch is a man of

27) Pronounced Kovatch.

28) Traditions and Reminiscences, p. p. 240-246.

29) Heitman's Register, p. 336.

30) J. M. Levering, History of Bethlehem, 1903, p. 485.

31) Traditions, p. p. $240-246$.

32) W. M. Kozlowski, "Pułaski w Ameryce," Biblj. Warszawska, 1905. 


\section{POLAND AND THE AMERICAN REVOLUTIONARY WAR}

great merit and deserves the Charge of Master of Exercises; he's an officer worthy of research and exclusive of a thorough knowledge of his abilities request his being employed by your Excelly. I can recommend him and assure your Excelly. will never have reason to repent your confidence in him, if this proposal should be agreeable to your Excelly., the sooner I am informed the better as he will be of infinite service to the Cavalry this winter in Quarters." 33)

Washington answered January 14, 1778:

"As so much has been said of the character and abilities of Mr. Crovatch, I have no objections to his being engaged in the capacity of Exercise Master for a few Months." 34)

When Pulaski later organized his Legion Kowacz, at his request, was commissioned Colonel. In the Spring of 1778, the officers of the Legion were sent to different cities to recruit volunteers. Kowacz was ordered to Easton, Pa. The Moravian diaries mention that on the afternoon of Maundy Thursday, April 16, 1778, Count Casimir Pulaski came into the church at Bethlehem. accompanied by the "well known Col. Kobatsch." ${ }^{35)}$ Their visit at Bethlehem had for its purpose to call upon the wounded Marquis Lafayette, to look for recruits and to negotiate with the artisans of Bethlehem to furnish the Legion the necessary accoutrements. They found, however, that in consequence of the lack of materials and occupation of the Brethren's House by the hospital, the oruer could not be accepted. Kowacz is again mentioned by the Moravian diaries July 31, 1778, when he passed through Bethlehem from Easton "en route for Baltimore, with his troopers, equipped and armed." ${ }^{36)}$ Evidently he was able to recruit and equip his detachment meanwhile.

In July, 1778, the British, reinforced by Indians, raided the Wyoming Valley in Pennsylvania and cut down a force of 400 American men and boys gathered hurriedly to oppose them. A panic followed among the inhabitants of the valley. The Board of War, at the request of the government of Pennsylvania ordered Col. Kowacz, then at Easton with "a small company of horse," to proceed there and guard the region. ${ }^{37)}$ Pulaski with the rest of the Legion was then in Trenton, still busy with its organization.

The presence of Col. Kowacz on the frontier did not satisfy the inhabitants. Robert Levers, writing from Easton, August 25,1778 , to George Bryan, Vice-President of the Executive Council, considered the appointment of Kowacz an "unhappy choice." $\mathrm{He}$ acknowledged that "in the Legion to which he belongs and

33) M. I. J. Griffin, Catholics and the Am. Rev., III, 34.

34) Letters, B, IV, 412

35) Levering, History of Bethlehem, 485.

36) Ib., p. 485 .

37) Colonial Records of Penna., XI, 531. 


\section{OTHER POLES IN THE REVOLUTIONARY ARMY}

for the service it is immediately raised he may doubtless distinguish himself," but he "is unacquainted with the country" and "the nature of Indian manner of fighting." ${ }^{38}$ ) But Congress had no other troops on hand. However, Kowacz must have been doing his duty well since later the whole Legion was sent to protect the frontier settlements.

Early in the Spring of 1779, Pulaski was ordered to Georgia, recently invaded by the British. Col. Kowacz accompanied the Legion on this march. Their presence helped to save Charleston, S. C., from capitulation before the enemy. Immediately after reaching the city, the Legion made an excursion against the British to lift the spirits of the beleaguered, May 11, 1779. Pulaski planned to ambush the enemy, but, because of misunderstanding, his infantry came out from its cover and the plan was frustrated. The Legion suffered heavily. "In this very gallant attack on the British advance, Pulaski had several personal encounters with individuals of the enemy, and was always the victor. His next in command, Col. Kowaltz, was not so fortunate. Having bravely engaged the enemy, he was severely wounded, and in the retreat, fell from his horse in the road. The British buried him where he fell, on the west side of the road, on land now owned and enclosed by John Margart, at the corner of Huger st." 39)

$$
\text { KRASZEWSKI - }{ }^{40)}
$$

Or Krassowski, who is said to have been a subaltern officer, killed in a battle. The author was unable to find anything which would throw more light on this officer. According to the author's knowledge, Kraszewski is mentioned only in a report about the American Poles prepared by Dr. Henry Kalussowski, an eminent physician of Washington, D. C., for Joseph I. Kraszewski (Boleslawita), the famous Polish novelist.41) Kalussowski was a lover of history and occasionally did some research work in government archives. His unquestionable honesty and high education vouch for the truthfulness of the statement. ${ }^{42}$ )

38) Penna Archives, ser. 2, vol. VI, p. 719.

39) Johnson, Traditions, p. 246.

40) Pronounced Krashefsky.

41) Kraszewski published the report of Dr. Kalussowski in Boleslawita's Rachunki z Roku 1867, Poznan, 1868, vol. II, p. 92.

42) H. Moscicki, (“America-Poland," Dzwon Wolności, Warsaw, 1926, p. 22.) mentions a Polish officer of the French army of a similar name Kossowski as a participant in the American Revolutionary War, but the search made by General Paul Azan, Chief of the Historical Service of the French Ministry of National Defense at Paris, at the request of the author brought out that there were two Polish officers of that name in the French army during the reign of Napoleon, neither of them, however, was in America with the army of Rochambeau. 


\section{POLAND AND THE AMERICAN REVOLUTIONARY WAR}

\section{LITOMSKI, CHARLES ${ }^{43}$}

Paul Bentalou, an officer of the Pulaski Legion, describing the attack on Savannah in his Pulaski Vindicated, ${ }^{44}$ ) says that the Polish General, just before he was wounded by an English grapeshot, left his post to see what was going on behind the screens of smoke and "called to accompany him one of the captains of his Legion, who is yet living but far advanced in years." Of course, the words "yet living" refer to the time when Bentalou wrote and published the above pamphlet.

According to some American historians, that Captain of the Legion, accompanying Pulaski on his fatal ride, was a Pole, Charles Litomski.

Heitman's Register does not contain his name, but this is not sufficient proof that Litomski did not serve in the Legion, or in the American army.

Benson J. Lossing mentions Litomski in his Pictorial Field Book of the Revolution, ${ }^{45}$ ) where he calls him "first Lieutenant" and "personal friend" of Pulaski. Thomas Balch also gives his name among the French officers who served in America. ${ }^{46)}$ A brief biography of Litomski by Tefft who misspels his name Litominsky, is given in The American Historical Record: 47)

"Litomski was at the siege of Savannah, as aide-de-camp to Brigadier Count Pulaski. He had the consoling satisfaction of supporting this Hero, in the struggles of death, and assisted in consigning his mortal remains to its kindred earth, under a large oak tree, about 50 miles from Savannah, upon the banks of an inlet, leading from Savannah to Charleston.

"He returned to his native country, Poland, in company of Kosciuszko, and united with him in fighting her battles in the memorable years of 1792 and 1794 .

"He afterwards joined the standards of Napoleon, and was attached to the second regiment of Polish Lancers. He was at the battle of Austerlitz, in 1805, where he received a severe wound in neck. He served five years in the Peninsular War.

"He was at the battle of Leipsic in 1813, and was in company with Prince Joseph Poniatowski, when he lost his life in attempting to swim the river Elster, after the bridge had been destroyed, at the termination of that fatal battle. He served in Napoleon's campaign against Russia, and was present at the battle of Moscow and Borodino. He witnessed the conflagration of Moscow, and was among the small remnant of the grand army of invasion, which returned to France from that disastrous campaign.

43) Pronounced Leetomsky.

44) Pulaski Vindicated, p. 32.

45) Pictorial Field Book of the Rev., II, 529.

46) Thos. Balch, The French in America, II, 168.

47) Am. Hist. Record, vol. I, No. 9. Sept., 1872. 


\section{OTHER POLES IN THE REVOLUTIONARY ARMY}

"After these events, he resigned his commission of Colonel, at the departure of Napoleon for the island of Elba, and retired to private life. He collected together the remains of his fortune, amounting to upwards of $\$ 35,000$, with the view of returning to America, the land of his early career, there to repose. But in Providence of God, the ship Two Brothers, in which he was embarked, was wrecked off Heligoland, near the river Elbe, by which disaster he lost nearly his all.

"After having passed three or four years in France and England, he came to this country, in 1831, with a reduced fortune," and after a brief stay departed, with the help of his friends, to Brazil, to spend his last days with an old companion. His further fate is not known.

According to Tefft, he was then an aged man "who had the appearance and gentlemanly bearing of a veteran soldier."

\section{ROGOWSKI, MATTHIAS ${ }^{48)}$}

The authenticity of this person is questioned by modern Polish historians. There exist, indeed, The Remnants of the Memoirs of Matthias Rogowski, Cuptain of the Polish Confederacy of Bar, published in Paris in 1847, describing Rogowski's and Pulaski's activities in America during the Revolutionary War. But the diary gives ample ground for suspicions that it was the product of the imagination of the Polish poet Constantine Gaszynski who signed the work as its editor. ${ }^{49)}$

The suspicions date since Prof. W. M. Kozlowski of Poland, after researches in America, published his "Pulaski w Ameryce" in the Bibljoteka Warszawska in 1905 . He was the first one to point out the inaccuracies and contradictions of The Remnants of the Memoirs, hitherto accepted as authentic by Polish and American historians. The absence of Rogowski's name in original documents of the Revolution, though not a positive proof in itself, gives an additional weight to this theory.

The Remnants contain many historical errors. They say, for instance, that Pulaski landed at Philadelphia, while the truth is that he landed at Marblehead, Mass., July 23, 1777. There are also other similar mistakes. Of course, there are no errorproof diaries, especially if these pertain to events described after a lapse of many years-as The Remnants pretend to be. On the other hand, they contain some particulars which in 1847, were not yet generally known. It is possible, then, that Gaszynski, who never was in America, had somebody here who made a little research work for him and later he himself completed the story from the just published Jared Sparks' Life of Count Pula$s k i,{ }^{50)}$ embellishing it with fiction.

48) Pronouced Roghofsky.

50) Born 1809 , died 1866 , belongs to the Polish romantic literature. 


\section{POLAND AND THE AMERICAN REVOLUTIONARY WAR}

For the authenticity of Rogowski speaks, to a certain degree, the authority of historiography. M. I. J. Griffin cites quite abundantly from The Remnants in his biography of Pulaski. ${ }^{51)}$ The eminent Polish historian, Thaddeus Korzon, used them for a biography Kosciuszko. ${ }^{52)}$ Edwin M. Stone in his work Our French Allies in the American Revolution mentions "Capt. Ragowski" among the wounded in the attack at Savannah, October $9,1779 .{ }^{53)} \quad \mathrm{K}$. C. Jones also says Rogowski was among the wounded officers at Savannah. ${ }^{54)}$ Finally, Rogowski is mentioned in Heitman's Register with the following annotation: Rogowski-, from Poland, Captain and Aide-de-Camp to General Pulaski, wounded at Savannah, 9-th Oct., 1779.55)

Considering all this the author places Rogowski among the Polish officers in the American Revolutionary War with a reservation that his authenticity is doubtful.

Gaszynski in his preface to The Remnants says that " 30 years ago," consequently about 1807, there lived at Raducz, District of Piotrkow, Poland, a "worthy citizen Matthias Rogowski, known in the whole county as 'Captain,' because he served in that rank in the Polish Confederacy of Bar for five years.

"He was also called 'American' because he visited that far off land with Pulaski, Kosciuszko, and several other Poles and fought for American freedom under the command of Washington.

"Everyone revered and liked Mr. Matthias, because he was hospitable and kind, gay and witty. He traveled extensively, had intercourse with many people, saw much and experienced much;his conversation, therefore, was very interesting and everybody always liked to hear his narratives, mixed with jocose anecdotes. No celebration in the vicinity, no christening party, nor wedding was complete without the 'Captain'; and when people prepared for a festival, everybody asked: 'How about the American, will he be there?'

"Rogowski always wore the Polish national dress. He was tall and slender and straight as a young man, notwithstanding his old age and bad health. His large mustache, white as milk, added dignity to his lean face, enlivened by a pair of large blue eyes. The scars of old wounds were visible on his bald-head and, when joking in company among the glasses, he often repeated that his head is hardened to drinks, because it is patched with lead and steel. Rogowski never married and was always proud of his bachelorship; an old sister, a childless widow, was his landlady.

51) Catholics and the American Revolution, vol. III.

52) Cracow, 1894.

53) Providence, R. I., 1884, p. 124.

54) History of Georgia, vol. II, p. 408.

55) Officers of the Cont. Army, p. 473. 


\section{OTHER POLES IN THE REVOLUTIONARY ARMY}

“The 'Captain,' after a long absence from the country, found his hereditary possession neglected and nearly ruined - and, because it was burdened with debts, he sold it and received a small sum which helped him to live from renting other possessions. But because he led a regular life and was thrifty, he did well; he did not abound in wealth, neither did he suffer want and without loss to his pocket could entertain guests, especially on the day of his Patron Saint.

"My father, though younger, lived in great frienship with the 'Captain'; they exchanged visits often and I, then a small boy, listened to their long talks with the greatest interest.

"Mr. Rogowski had a large book bound in red Morocco in which he described his whole life, his wars and travels; when asked, I remember, he sometimes took the book from his desk and read aloud various parts of it, to which all listened in silence, and afterwards showered the author with praise. Later, when I was older and came home from Warsaw for vacation, I often slipped away to Raducz, to Mr. Rogowski, who loved me very much and loaned me his Polish and French books, allowing me also to read from his large, red book. The title of this manuscript was, as I remember: A Narrative of the Events which I as a young man took part in or was witness of.

"Mr. Rogowski died in 1828, and his sister, having rented the estate to somebody else after selling out his cattle, and movable goods, left for Kuyavy." $\left.{ }_{56}\right)$ The memory of the "Captain" was slowly lost. Gaszynski recalled the book only when he found himself in France after the Polish Revolution of 1830-31, in which he took an active part, and with the help of a friend recovered the manuscript, already much damaged. He edited and published The Remnants. The efforts of Polish historians to verify Gaszynski's statements were hitherto fruitless.

Rogowski, according to his diary, is said to have been an inseparable companion of Casimir Pulaski during his exile from Poland and came with him to America. At Brandywine, "he received a good trashing and was wounded in the head by a red dragoon whom, however, he bravely despatched to another world." When Pulaski was made General of the Cavalry he was commissioned Major and in this character he made the northern campaign; later he was transferred to the Pulaski Legion as Captain and aid-de-camp to Gen. Pulaski; he participated in the southern campaign and was wounded at Savannah, October 9, 1779, when rushing to the aid of his wounded commander. The Remnants close with the death of Pulaski.

56) A province in middle Poland. 


\section{POLAND AND THE AMERICAN REVOLUTIONARY WAR}

\section{TERLECKI- ${ }^{57)}$}

First name unknown. What was said of Kraszewski pertains also to Terlecki. He is mentioned in the report of Kalussowski to J. I. Kraszewski. ${ }^{58)}$ service.

Terlecki was said to be an officer and died in the American

It is possible, that the same Terlecki appears in the List of Select Militia of Maryland as Tilliskey, Jacob. ${ }^{59)}$ Tilliskey is a distinctly Polish name, anyhow.

\section{ZIELINSKI, JOHN ${ }^{66)}$}

Zielinski was a relative of Gen. Casimir Pulaski, whose mother was nee Zielinski. Heitman gives his service record as follows: Zielinski John de, from Poland, Captain of Lancers, Pulaski Legion, commissioned April, 18, 1778, died September $25,1779$.

Zielinski came to America much earlier than the date of his commission. Unable to get it sooner, he remained with Pulaski, then Commander of Cavalry, as a volunteer without rank. The documents of the Continental Congress call him "a gentleman and an officer in the Polish service" which shows, as well as Pulaski's letters, that he served in the Polish Confederacy of Bar.

$\mathrm{He}$ is first mentioned in America in October, 1777, on the occasion of the court-martial of Colonel Stephen Moylan, commander of one of the four cavalry regiments. Moylan, it is said, felt offended when Pulaski was made General and Commander of Horse thinking himself to be more entitled to the position. Consequently there never was harmony between the two as long as Pulaski commanded the cavalry. Their hostility spread to their surroundings and brought out a clash. On October 24, 1777, Moylan was tried before a court-martial charged with "a cowardly and ungentleman like action" in striking Mr. Zielinski, when disarmed and putting him under guard, disobedience of orders of Gen. Pulaski, and "giving irritating language" to Pulaski.

The court declared Moylan not guilty and Washington approved of the verdict, October $31 .{ }^{61)}$

It is impossible to decide now the merits of the case. However, Marquis Lafayette mentions this court-martial in his memoirs and it gives him an opportunity to criticize the partiality of the American Revolutionary court-martials. ${ }^{62}$ )

\footnotetext{
57) Pronounced Terletzky.

58) Boleslawita, Rachunki z r. 1867, vol. II, p. 92.

59) Archives of Maryland, vol. XLVII, p. 458.

60) Pronounced Zelinsky.

61) MSS Cont. Cong., II. 341.

62) Memoirs, p. 58.
} 


\section{OTHER POLES IN THE REVOLUTIONARY ARMY}

The controversy did not end here. Zielinski challenged Moylan to a duel. Moylan informed his seconds that he declines to fight with a man, whom he considers "neither a gentleman, nor an officer and that he will order his servant to give him a good licking wherever he will happen to meet him."

The threat proved a boomerang. Touched by this insult, Zielinski meeting Moylan by chance outside the camp a month later, struck him with a stick and when Moylan grasped his saber and pistols, threatening Zielinski with arms, he unhorsed the Colonel with one strike of his lance. ${ }^{63)}$

Pulaski immediately reported the affair to Washington and sent the letter by the dragoon who witnessed it. Moylan demanded court-martial, but later changed his mind. The courtmartial never met and the affair went into oblivion. ${ }^{64)}$

All this took place during the winter of 1777-78, which Pulaski spent at Trenton, N. J. It was his plan to form a choice detachment of cavalry, armed with lances, of which the Poles were masters. He personally taught his soldiers the use of it and repeatedly asked Washington and Congress to authorize the organization of the regiment of lancers. He proposed Zielinski as its Lieutenant, assuring Washington that he is a talented officer, experienced in the use of the lance. ${ }^{65}$ )

The project, however, did not receive the sanction of Congress, mainly because of lack of money. Zielinski had to wait yet without commission. But when in the Spring of 1778 , Pulaski started to organize his Legion, he again proposed him as an officer of the horse and now the proposition was approved by Washington and Congress. Zielinski was made Lieutenant, April 18, 1778, and was one of the three first officers of the Legion.

He shared the fate of the Legion throughout his career and evidently did not deceive the assurances of Pulaski as to his talents and bravery for he is later noted in the documents with the rank of Captain.

He was another Pole who died on the field of glory, for the freedom of America. He expired September 25, 1779, during the southern campaign of the Legion, but the circumstances of his death are not clear.

Prof. Kozlowski supposes ${ }^{66)}$ that he was wounded by the British at Savannah, in their sally from the city, September 24th, and died next day.

However, there is another version of this fact. A Revolutionary veteran, Saville, writing to the Nashville Banner about Pula-

63) Letters of Pulaski to Washington and depositions of witnesses, MSS Cont. Cong., XXI, 215, 275.

64) W. M. Kozlowski, "Pułaski w Ameryce," Biblj. Warsz., 1905.

65) Letters to Washington, XXI, 215.

66) "Pułaski w Am.", Biblj. Warsz., 1905. 


\section{POLAND AND THE AMERICAN REVOLUTIONARY WAR}

ski, Kosciuszko and their common friend, Gen. Davie, mentions also "a young Pole - Zielinski.".

"Zielinski" - he says - "died in a hospital in Charleston, where Gen. Davie was at the time confined from a wound received at the battle of Stono, which afforded him the melancholy satisfaction of sharing in the sad duties to one dear to him for his noble qualities and long suffering." 67 )

William Richardson Davie of North Carolina, afterwards American minister at Paris, was in the beginnings of his military career Lieutenant, and Captain of the Pulaski Legion. It was at his request that Kosciuszko wrote the Manoeuvres of the Horse Artillery, the first handbook of its kind in the United States, which gained for him the title of the "Father of American Artillery."

The above mention of Zielinski proves that he must have been wounded in the attack of Pulaski at Charleston, May 11, 1779 , or in the skirmish at Stono Ferry, June 20, 1779, together with Davie, and that he lingered between life and death in the hospital in Charleston for some months.

The words of Saville acquaint us with the character of Zielinski. His misunderstandings with Moylan, however unpleasant, are entirely excusable and human. It was his attachment to Pulaski, his old commander, which caused him to disagree with the Irishman - a cause rather laudable. His promotion to the rank of Captain and his death are proofs that he served this country well and to the utmost of his capacity. The flattering remembrance of an old comrade attests to his good personal character.

Among the above mentioned heroes, who crossed the Atlantic to fight for America's independence, three are of dubious Polish origin: - Baldeski, Elholm and Kowacz, and one, Beniowski, was born in Hungary, though he considered himself a Pole.

From among these fourteen officers, including Kosciuszko and Pulaski, two attained the rank of Brigadier Generals, one Colonel, one Lieutenant Colonel, one Major, others were Captains and Lieutenants. Beniowski alone was never commissioned.

We now turn to the other group of Poles in the American Revolutionary army, i. e. the Poles from the colonial immigration, who settled in America before the Revolution. The following roster was prepared on the basis of various state registers, federal pension lists and other documents. Undoubtedly, the author was not able to avoid including in this roster the names of certain Americans and others of non-Polish extraction. On the other hand, he probably left out some Poles whose names were inde-

67) Niles Register, LXXIII, 68. 


\section{OTHER POLES IN THE REVOLUTIONARY ARMY}

scernible. To verify each name genealogically would be a nearly impossible task. For the sake of accuracy and to facilitate corrections each name is given as found in the records and with its documentary sources.

\section{CONNECTICUT}

(Family names given before first names)

BARSK JOHN (also Barsh), Private, Fourth Co., Third Rgt. (Gen. Putnam's), Cont. Army, recruited in Windham and New London counties in $1775 .{ }^{68)}$

BEKAS GEORGE, Private, Capt. Parmelee's Co., Col. Elmore's Rgt., Cont. Army, recruited in April 1776 for 1 year. ${ }^{69)}$

BROGA ANDREW, Private. Lived in Becket, Mass., after the war; in 1841 was 82 years old.70)

ICAISKY JESSE, (Isaacs), Sailor on the Continental frigate Confederacy. ${ }^{71)}$

LUSKE SOLOMAN, (also Lusky,) Private, Second Rgt., Connecticut Line; enlisted Sept. 1, 1780; discharged Dec. 13, 1780. ${ }^{72)}$

\section{DELAWARE}

DUSKY JOHN, Private, Delaware Continental Line; Revolutionary pensioner; died August 24, 1823. ${ }^{73)}$

FABRICIUS JOHN C., Private, Revolutionary pensioner. ${ }^{74}$

\section{GEORGIA}

MASNEY THOMAS, served in one of the Rgts. of the Line. ${ }^{75)}$

ZAWADOOSKI PETER, (probably Zawadzki), Private; Rev. olutionary pensioner; lived in Chatham County in 1839. ${ }^{76)}$

\section{MARYLAND}

CHALUPETZKY JOSEPH, (the correct spelling probably Chalupecki), Private, Armand Legion; enlisted in 1782. ${ }^{77)}$

68) Record of Service of Connecticut Men in the War of Revolution, War of 1812, Mexican War, Hartford, 1889, p. 55.

69) Ib., p. 166.

70) Ib., p. 640; Census of Pensioners for Revolutionary and Military Services, Washington 1841 , p. 32 .

71) Record, p. 601

72) Ib., p. 166.

73) Delaware Archives, Rev. War, III, 1232.

74) Letter from the Secretary of War, in relation to the Pension Establishment, June 1, 1813, p. 530. As to the possibility of Fabricius' Polish origin vide M. Haiman's Polacy wśród Pionierów Ameryki, Chicago, 1930 , p. p. $24-28$.

75) Geo. G. Smith, The Story of Georgia, Macon, 1900, p. 626.

76) Historical Collections of J. Habersham Chapter, D. A. R., II, 613. p. 594 .

77) Archives of Maryland, Muster Rolls of Md. Troops in the Rev., 


\section{POLAND AND THE AMERICAN REVOLUTIONARY WAR}

DESKEY JOHN, Private, Third Co., Second Battalion, Maryland Line; enlisted Jan. 1, 1782. ${ }^{78)}$

TILLISKEY JACOB, Special Militia. ${ }^{79)}$

\section{MASSACHUSETTS}

BLUSKEY FREDERICK O., from Gardner; Private, Fifth Co., Col. G. Bradford's Rgt., Cont. Army ; enlisted March 8, 1777; appears to have served till the close of the war; in the office of the armorer since March 1780. ${ }^{80}$ )

DESKO SAMUEL, Private, Capt. J. Hall's Co., Col. B. Fosters Rgt.; served from Aug. 7, 1779. ${ }^{81)}$

FRANKO MICHAEL, Seaman on the frigate Boston; engaged July 15, $1779 .{ }^{82)}$

LASKEY, also Lakey, Lashy, Laskee, Laskey. Thirty persons of that name appear in Mass. Soldiers and Sailors in the Rev. War. ${ }^{83)}$ They were mostly sailors from Marblehead, Mass., where this family of fishers and mariners lived in great numbers. ${ }^{84)}$ The most conspicuous records are of :-

LASKEY JAMES, Lieutenant, detached for the defense of the sea coast at Marblehead; commissioned Jan. 16, 1778; served since Feb. 20, 1776, as Gunner's Mate, Capt. E. Fettyplace's Co.

LASKEY JOHN, Seaman, brigantine Massachusetts; engaged Feb. 17, 1777. ${ }^{85)}$

LASKEY NATHANIEL, Private, Capt. Lane's Co., Col. Nixon's Rgt.; enlisted March, 16, 1777; died in the service some time after Feb. 16, 1779.

78) Ib., p. 446.

79) Ib., XLVII, 458.

II, 220.

Ma) Massachusetts Soldiers and Sailors in the Rev. War, Boston, 1896,

81) Ib., IV, 699.

82) Ib., VI, 19.

83) Ib. IX, 531-533.

84) Vital Records of Marblehead, Marblehead, Mass., 1903-4. According to some historians (W. Kruszka, Historja Polska $w$ Am., vol. 1.; Boleslawita, Rachunki $z r$. 1867, II, 86), this colonial family comes from the noble family Laski prominent in the history of Poland. John Laski, Polish religious reformer, lived in London in the middle of 16-th Century and married there for the second time after the death of his first wife. $\mathrm{He}$ was later expelled from England by Mary. Tudor and died in Poland, leaving nine children (A. Brueckner, Różnowiercy Polscy, Warsaw, 1905, p. p. 7-89). It is possible, that some of them, especially the son Jerome, later returned to England. J. Farmer in his Genealogical Register of the First Settlers of New England (Lancaster, Mass., 1829, p. 174) says that Hugh Lasky (Laskin) was the first of the family to settle in Salem, in 1637, a few years after the foundation of the colony. In 1639 this Lasky was made a freeman and died in Salem in 1659. The Laskys were quite numerous in Salem and also in other towns of Massachusetts, but mostly in Marblehead.

85) This ship brought Benjamin Franklin to France and Casimir Pulaski to the United States. 


\section{OTHER POLES IN THE REVOLUTIONARY ARMY}

OBLEFFSIKIE FREDERICK, (the spelling should probably be Oblewski). Mass. Soldiers and Sailors in the Rev. War contain four soldiers of the same name with following variations of spelling of the family name: Obliske, Obliskie, Oblufskin. Obleffsikie enlisted at the age of 32 years in the militia of Brig. Gen. J. Fellows, date unknown; Obliske served in Capt. Lamont's Co., Col. Bradford's Rgt., from March 8, to May 10, 1777; Obliskie, a soldier in Col. E. Thayer's Rgt., died at West Point, Aug. 27, 1780; Oblufskin enlisted in Capt. Lamont's Co., Col. Bradford's Rgt., Feb. 2, 1778. Probably all four records pertain to one person. ${ }^{86)}$

PASKO JOHN, Private, Continental Army; Revolutionary pensioner; in 1818, was 74 years old and lived in Warren Co., Mass. ${ }^{87)}$

PESKO ROBERT, Corporal, Capt. Wm. White's Co., Lt. Col. J. Brook's Rgt.; enlisted at West Point, Jan. 1781, for the war. ${ }^{88)}$

POLAN and similar names: Polen, Polens, Polin, Polland, Poland, etc. are about fifty in the records of Massachusetts. Some of them may be of Polish origin, especially Polan Joseph, Private, Col. J. Mansfield's Rgt.; enlisted in Beverly for three years in 1775. ${ }^{89)}$

ROSONOSCHY DONDER, (probably Rozanowski), Sergeant, Armand Legion. ${ }^{90)}$

\section{NEW HAMPSHIRE}

ISAKI AUGUST, (also Isakl), Private, Capt. L. Olivies' Co., Col. M. Hazen's Rgt. ${ }^{91)}$

\section{NEW JERSEY}

DEASKEY LEMAN, Private, Second Battalion, Second Establishment, Second Rgt.; Revolutionary pensioner; died in Switzerland Co., Ind., Feb. 15, 1829, 83 years old. ${ }^{92)}$

MALICK ANDREW, Captain, First Rgt., Sussex Co. ${ }^{93)}$

MALICK JOHN, served in militia. ${ }^{94)}$

86) Mass. Soldiers and Sailors, XI, 612-13.

87) Report from the Secretary of War, in relation to the Pension Establ., Washington, 1835, II, Mass., 253.

88) Mass. Soldiers and Sailors, XII, 236.

89) Ib., XII, 489.

90) Ib., IV, 865, family name erronously recorded as first name.

91) The State of New Hampshire, Part I, Rolls and Documents relating to Soldiers in the Rev. War. IV, 304.

92) Official Register of Officers and Men of New Jersey in the Rev. War, Trenton, p. 181; Report from the Secr. of War in relation to the Pension Establish., 1835, IV, Ind., 33.

93) Off. Reg., p. 400. A Polish family of Malich mentioned in New Sweden in the 17-th Century (M. Haiman, Polacy wśród Pionierów Am., p. 30$)$.

94) Off. Reg. 239. 


\section{POLAND AND THE AMERICAN REVOLUTIONARY WAR}

ZABRISKIE. - This family descendant of Albrecht Zaborowski, a Polish noble, who settled in New Amsterdam in 1662, is a typical example how the Revolutionary War divided the families. Some of the Zabriskies remained faithful to England, while others supported the Revolutionary cause and fought as American soldiers. The last appear to be in the majority. Jacob C. Zabriskie, grandson of Albrecht, born in Lower Paramus, N. J., Jan. 10, 1725, moved to Arcola where he kept the "Old Red Mill." $\mathrm{He}$ was an ardent patriot, his determined spirit gaining for him the name of "King Jacob." 95) Gen. J. Huntington reported to Gen. William Heath from Camp Ramapough, N. J., Nov. 25, 1776, that the local Tories "have given a specimen of their valor by shooting a Whig, one Zabriskie." 96) The house of another Zabriskie, Peter of Hackensack, N. J., was the headquarters of Gen. Washington in 1776, during his retreat from New York. The Commander-in-Chief stayed there for several days. Peter Zabriskie early took part in the activity of the patriots. He presided over a meeting of citizens from Bergen County, June 25, 1774 , to discuss "the alarming tendency of the Act of Parliament for the purpose of raising a revenue in America." 97) The Revolutionary rolls of New Jersey contain the following Zabriskies:

ZABRISKIE JOHN, Lieutenant-Colonel of militia of Bergen County, one of the first citizens of the County where he held the office of judge. Undecided in the beginnings of the Revolution with what side to identify himself, he finally leaned to the British Crown, resigning his commission in the militia, June 16, 1776.98) County. ${ }^{99)}$

ZABRISKIE YOST, Lieutenant of militia of Bergen

\section{NEW YORK}

BALYCA SIMON, Sergeant, Johnson's Rgt. 100)

BURCKY PETER, (also Burcki), Private, Tryon Co. Militia, Fourth Rgt.; he served also in the Continental Army; in 1831 lived in Herkimer County, N. Y., then 80 years old. 101)

95) Fr. B. Lee, Genealogical and Memorial History of New Jersey, I, 297. As to the origin of Zabriskies' see New York Genealogical and Biographical Record, vol. XXIII; also M. Haiman's Polacy wśród Pionierów Ameryki, p. p. $13-23$.

96) Heath Papers, Coll. of Mass. Hist. Soc., IV, 27.

97) Fr. A. Westervelt, History of Bergen County, I, 101, 106; II, 493. The house of Peter Zabriskie, built in 1751, is still standing and retains many of the original features. A bronze tablet was placed by the Bergen County Historical Society on the outer stone wall with a proper inscription.

98) Off. Reg., 339, 362; Westervelt, History of Bergen Co., I, 127.

99) Off. Reg., 435. As to the Zabriskies Loyalists see the chapter:Poles among the Loyalists.

${ }_{100)}$ N. Y. State Arch., N. Y. in the Revol., I. 317. Report from the Secr. of War in relation to the Pension Establ., II, N. Y., 232. 


\section{OTHER POLES IN THE REVOLUTIONARY ARMY}

BURDJAT CONRAD, (also Burdjah), Private, Westchester Co. Militia, Third Rgt. ${ }^{102)}$

CARAREYCH HERONIMUS, (this seems to be a distinctly Polish name Karasiewicz), Private, Ulster Co. Militia, First Rgt. 103)

JEEFE RINAS CAESSIMGIR, Private, Albany Co. Militia, Third Rgt. ${ }^{104)}$

KAGHAATSKO NICHOLAS, (also Kayatshe), grade and regiment unknown. ${ }^{105)}$

KRAK GODLIEB, Private, New York Line; at West Point, July 6,1780 . ${ }^{106)}$

KURAW MICHAEL G., Private, Continental Army; Revolutionary pensioner; in 1827 lived in Otsego Co., N. Y., then 77 years old. 107)

KUSHEL JOSEPH, Private, Third Rgt., Continental Army. ${ }^{108)}$

MALICK JOHN, Private, Continental Army; Revolutionary pensioner; in 1833 lived in Schoharie Co., N. Y., and was 75 years old. ${ }^{109)}$

POLASKIE ANTHONY (also Polasker and Polascy), Private, Orange Co. Militia, Second Rgt. ${ }^{110}$ )

POLOSKE ELHAM (probably the same name as the foregoing), one of 8,000 American soldiers kept at the English prison ship Old Jersey at New York during the Revolution. Most of them died in consequence of horrible conditions. ${ }^{111}$ )

SOHAKE JOHN, (also Sohock), Private, Graham's Rgt. ${ }^{112)}$

ZABRISKY JOHN C., (also Labriska and Zabriska), Private, Albany Co. Militia, First Rgt.; Private, Schuyler's Rgt.; Private, Lansing's Rgt. 113)

102) N. Y. State Arch., I, 335; Roberts, 210.

103) Roberts, 187.

104) Ib., 324; Caessimgir as family name in the records, though it seems to be the first name, Casimir.

105) Ib., 270; Kaghaatsko seems to be a distinctly Polish name Kawecki, or Kajecki.

106) Coll. N. Y. Hist. Soc., Muster and Pay Rolls of the Rev., 434.

107) Report from the Secr. of War, II, N. Y., 215.

108) N. Y. State Arch., I. 200.

109) Report from the Secr. of War, II, N. Y., 422.

110) Roberts, 159,$254 ;$ N. Y. State Arch., I. 488. Polaskis were a noble family from the Province of Great Poland.

111) D. Dandridge, American Prisoners of the Revol., Charlottesville, Va., 1911, p. 480.

112) N. Y. State Arch., I, 478 .

113) Ib., I, 411, 524; Roberts, 222 


\section{POLAND AND THE AMERICAN REVOLUTIONARY WAR}

\section{NORTH CAROLINA}

BAKUT PETER, Captain, Tenth Rgt:; commissioned Sept. $8,1781 .{ }^{114)}$

LASKEY GEORGE, Private, Col. F. Lock's Rgt. ${ }^{115)}$

LOVICK MOSES. ${ }^{116)}$

\section{PENNSYLVANIA}

BONIA JOHN. ${ }^{117)}$

BONITA HENRY. ${ }^{118)}$

BOLICH JOHN, Private, Lancaster Co. Militia. ${ }^{119)}$

BOLICH PETER, Private, Berks Co. Militia. ${ }^{120)}$

BOZEC ALEXANDER, 121)

DELWICH CASIMIR, (also Delwick), Private, First Rgt. Continental Line; enlisted from Lancaster Co., May 1, 1776. ${ }^{122}$ )

DOLO JOSEPH, Lieutenant, Eighth Rgt., Continental Line. ${ }^{123)}$

DOMAN JOHN, Drummer and Fifer, Third Rgt. on foot; enlisted in Philadelphia, Aug. 10, 1780. ${ }^{124)}$

DOMAN MARK, Private, Third Rgt. on foot. ${ }^{125)}$

DONICH HENRY, Private, Baron Ottendorff's Corps; enlisted Dec. 10, 1776. ${ }^{126)}$

GARNY ADAM, Private, Northampton Co. Militia in 1781. 127)

KNIAS JACOB, (also Kunias), Private, Armand Legion; enlisted Jan. 16, 1780, for 3 years. ${ }^{128)}$

KOKOGAI SAMUEL (also Kookogey, Hockugoi, Hockuhoy, Hockogoy), Musician, Fourth Rgt., Continental Artillery; enlisted May 15, 1778; died in Philadelphia, Sept. 1, 1828, 98 years old. ${ }^{129}$ )

114) No. Car. Hist., and Geneal. Register, II, 184.

115) State Records of No. Car., XVII, 1056.

116) Ib. XVII, 26. Probably a descendant of the Lowicks, a pioneer family, known in Virginia's and North Carolina's history. There is a strong supposition that they came from a Polish noble family Lowicki.

117) Penna. Archives, 2, XIII, 19.

118) Ib., 2, XIII, 19.

119) Ib., 5, IX, 991.

120) Ib., 5, V, 282.

121) Ib., 2, XIII, 22.

122) Ib., 2, XI, 38, 339; 5, II, 651.

123) Deutscher Pionier, VIII, 497.

124) Penna Archives, 2, XIII, 768.

125) Ib., 2, XIII, 776.

126) Ib., 5, III, 896, 899

127) Ib., 5, IV, 322; VII, 599.

128) Ib., 2, XI, 153; 5, III, 866, 878.

129) Ib., 5, III, 983, 1012; IV, 188; Report from Secr. of War, III,

Pa., 112. According to Penna. Arch., 2, XV, 697, he came from Germany. But among his living descendants there exists a tradition that Samuel was a Pole. Mr. S. M. Kookogey of New York wrote to the author, Nov. 5, 


\section{OTHER POLES IN THE REVOLUTIONARY ARMY}

KOWAN JACOB, Private, Sixth Battalion, Chester Co. Militia; enlisted April 24, 1781. ${ }^{130}$ )

KRACOLO HENRY, Private, Third Battalion, Northampton Co. Militia. ${ }^{131)}$

KUSKY BARNADOS, Private, Second Battalion, Northampton Co. Militia; enlisted May 28, 1782, for 60 days. ${ }^{132)}$

LESHINSKEY SIGMOND (correctly Leszczynski), Private Capt. Balliet's Co. from Bethlehem, Pa. ${ }^{134)}$ itia, $\left.{ }^{135}\right)$

LEVASVICK GEORGE, Private, Westmoreland Co. Mil-

MIDERA SAMUEL. ${ }^{136)}$ lery. ${ }^{137)}$

MITSCO CONRAD, Private, Fourth Rgt., Continental Artil-

NIEMERICH GODLIEB, (also Neimrich), Private, Baron Ottendorff's Corps; also Pulaski Legion, and Armand Legion. ${ }^{138}$ )

STACH RICHARD, Fifer, Fourth Rgt., Continental Line. ${ }^{139)}$

1930:- "When my grandfather was alive, he often mentioned the fact that the original Kookogey came here from Poland, and was known as Count Kokoski, and that he was obliged to leave Poland as he was condemned to be hanged for revolutionary activities in Poland; and that he enlisted at Valley Forge as a musician on May 15, 1778, and my grandfather's information was that he was actually a spy in the Continental Army and was enlisted as a musician as a matter of protection. The name is spelled in so many different ways and it is difficult to arrive at any definite conclusion, although my application to the Sons of the Revolution was accepted in 1907, as a descendant from S. Kokogai who served as a musician in Col. Proctor's Regiment." The note of German origin of Kokogai in Penna. Archives is not a positive proof of his nationality. The family tradition has an appearance of truth. Some parts of Poland were under the German rule already at the outbreak of the Revolutionary War. Moreover, the name Kokogai is not German, but rather Polish and seems to be a transformation of the common Polish name Kolodziej which sounds like English Kologai. It is possible that Kokogai took part in the Polish Confederacy of Bar and had to leave the country after its downfall. The supposition that Kokogai and "Count Kokoski" (probably Kotkowski) were one person is, however, without historical foundation.

130) Penna. Arch., 5, V, 726.

131) Ib., 5, VII, 232.

132) Ib., 5, VIII, 185

184) Ib., 5, VIII, 205. The noble family of Leszczynski (Leshehinsky) is very prominent in the Polish history. One of its members, Stanislaus Leszczynski, (born 1677, died 1766) was elected King after the death of John Sobieski and undoubtedly the American Sigmond was his relative, as the Leszczynskis were the most ardent and powerful protectors of Moravian Brethren in Poland before their exodus to America. Sigmond was superintendent of Brethren's House in Bethlehem, $\mathrm{Pa}$.

135) Ib., 5, IV, 444.

136) Ib., 2, XIII, 161.

137) Ib., 2, XV, 699.

138) Ib., 5, III, 903; Saffell, Records of the Rev. War. Niemerich (correctly Niemirycz) is an old Polish noble name.

139) Ib., 5, II, 1096. Stachs belonged to Polish nobility, though there were also Stachs among German nobles. 


\section{POLAND AND THE AMERICAN REVOLUTIONARY WAR}

YANELETZ FREDERICK, Private, Lancaster Co. Militia; enlisted April 12, 1781. ${ }^{140)}$

\section{VIRGINIA ${ }^{141)}$}

CISKO THOMAS ${ }^{142)}$

COPERA FRANCIS. ${ }^{143)}$

HALLICIA JOHN. 144)

KOSLOW JACOB. ${ }^{145)}$

REY ANDRE, Surgeon. ${ }^{146)}$

SADOWSKY JACOB. ${ }^{147)}$

SANDUSKIE JONATHAN, (also Sanduskey and Sadusky), Private, Continental Army; enlisted for three years; received 100 acres of land in Kentucky. 148)

SANDUSKY ANTHONY. 149)

SEDUSKEY JAMES (also Sodowsky and Sandusky); took part in the expidition against the Indians in Kentucky in 1779; died in 1831 in Bourbon Co., Ky. ${ }^{150}$ )

\section{STATE APPURTENANCE UNKNOWN}

DEBROSKEY JOHN, (probably Dombrowski), Private, Continental Army; Revolutionary pensioner; in 1824 lived in St. Louis, Mo. ${ }^{151)}$

GABRIEL JOSEPH, born in Poland; served with the Pulaski Legion and was in the attack at Savannah. After the Revolutionary War he remained in America. When the second war with England broke out in 1812, he again enlisted with the American army and was wounded in the leg in one of the battles. As an old man he lived in an alms house in New York, where he died August 14, 1829. 152)

140) Ib., 5, VII, 999.

141) Revolutionary documents of Rhode Island and South Carolina do not show any Polish or supposedly Polish names.

142) Eighth Annual Report of the Library Board of Virginia State Library, 1910-11, Richmond, 1912, p. 96.

143) Ib., 112.

144) Ib., 197.

145) Ib., 427.

146) Ib., 370. Rey is a name of an old Polish noble family; colonial documents mention a few Reys, apparently of French origin.

147) Ib., 387. Sanduskys are the descendants of a Polish immigrant who came to America in the beginning of 18-th Century. Their name was originally Sadowski. Jacob Sadowsky was the well known pioneer of Kentucky. (M. Haiman, Polacy wśród Pionierów Ameryki, p. p. 59-71).

148) Ib., 387, 389; Year Book of the Sons of the Revolution in Kentucky, Lexington, 1903, p. 258.

149) Eighth An. Rep., Va. State Libr., 389.

150) Ib., 389, 394; L. A. Burgess, Virginia Soldiers of 1776 , I. 440. Brother of James, also a pioneer of Kentucky.

151) Report from the Secr. of War, in rel. to the Pension Establ., 1835, IV, Mo., 4.

152) Vital Records of R. I., 1, XXI, 181. 


\section{OTHER POLES IN THE REVOLUTIONARY ARMY}

LOUGHGASKI MATTHIAS, Private, Continental Army; Revolutionary pensioner; after the war lived in Baltimore. ${ }^{153)}$

SNAUGHDER THOMAS, (perhaps Schneider), born in Poland; came to America during the Revolutionary War and served in Pulaski Legion; died in Kentucky, 105 years old. ${ }^{154)}$

This register contains over a hundred and ten names of the Revolutionary soldiers. Two of them are recorded as dead in the service and one as dead in the British prison. Some of the names are distinctly Polish, others are supposedly such.

Together with the Poles of the war immigration, over 125 Poles, or Americans of Polish origin fought in the American Army for the freedom of the New World in 1775 - 1783 .

During the eight years of the war 375,000 to 395,000 officers and soldiers passed through the ranks and files of the Continental army, state armies and militias. Compared with this number the Polish part in the war for independence of America seems small. The immortal merits of Kosciuszko and Pulaski sanctified and enlarged this part to a high degree. But, even without these two famous names, the Americans of Polish extraction have good reason to claim that their forefathers deserved well of America in those times "that were trying men's souls" and did their part to win her freedom.

153) Report from the Secr. of War, III, Md., 7. Is there any connection between this soldier and an old Revolutionary romance: Interesting History of the Baron de Lovzinski, with a relation of the most remarkable occurences in the life of celebrated Count Pulaski, well known as the Champion of American Liberty, and who bravely fell in its defense before Savannah, 1779, of which several editions were published in New York soon after the Revolution? Lovzinski has a Polish sound very similar to Loughgaski. It is a historical novel spun around the life of Casimir Pulaski, but totally phantastic. Its hero, Baron de Lovzinski, is represented as the son-in-law of Pulaski while the truth is that Pulaski was never married, had no children and died still very young. The death of Pulaski ends this novel, full of fiction. Such books were very popular in America after the Revolutionary War. They were also popular in Europe. It seems that the Interesting History of the Baron de Lovzinski was only a translation of a French novel Les Amours de Chevalier de Faublas, by Louvet du Coudray, published in Paris in 1789. The History of Lovzinski, now a bibliographical rarity, was reprinted in 1929, the year of sesquicentennial of the death of Pulaski, in Plattsburg, Mo., under a changed title: Historical Facts in the Lives of Count Pulaski and Baron de Lovzinski. It was put into circulation as an original work and pretended to be the true biography of Pulaski. This plagiarism found its way into the American press and some of the newspapers used it as a source of Pulaski's biography.

154) Vital Records of R. I., 1, XXI, 181. 

V.

POLES IN THE

REVOLUTIONARY NAVY 



\section{MIKLASZEWICZ, FELIX ${ }^{1)}$}

Though the Poles were never a maritime nation, the Polish immigrant in the United States can boast of the fact that among the few foreigners who served under the American flag on the seas in the Revolutionary War there was also a Pole.

The Continental Congress built, armed and commissioned many men-of-war during the Revolution. Several colonies also equipped more or less numerous state fleets. The American navy won laurels in more than one expedition and gained victories in many encounters.

But the burden of carrying on the war on the seas lay not so much on the American navy as on the privateers. It was they who by their bold raids constantly harassed the English on the sea. They captured British vessels loaded with supplies; they sometimes attacked and even overpowered the English men-ofwar. In this way the privateers not only undermined the British power, but at the same time secured military supplies for the American army.

Since privateering yielded large gains, it naturally attracted many volunteers. The Continental Congress and the separate States had many difficulties in manning the ships of the navy because the sailors would rather serve on the privateers. They were lured there by the freedom from military discipline and larger incomes.

Privateering demanded, besides a good knowledge of seamanship, also a high degree of courage. This was a war against a foe determined to crush the rebellion, and many privateers paid for their boldness with their lives or with imprisonment on the horrible prison ships at New York or in the not less intolerable prisons of England.

But the dangers of privateering did not deter Felix Miklaszewicz, a Polish noble, from following the example of other Americans in this form of warfare.

There is no doubt that Miklaszewicz belonged to the Polish nobility. Works on Polish heraldry mention his name as that of an old noble family from the Palatinate of Witebsk. ${ }^{2)}$ It appears also in the Palatinate of Polock in the 17th century. Felix Miklaszewicz rightly affixed the prefix "de" to his signature on some of the American documents.

The author tried to penetrate the mystery of his past in Poland by means of correspondence with eminent Polish historians. Their researches, however, did not bring out any record

1) Pronounced Meeklashevitch.

2) Zernicki-Szeliga, Der Polnische Adel, Hamburg, 1910. 
of his past. Only the archives of the Majorat of Nieswiez at Warsaw contain several letters signed Miklaszewicz to the Prince Charles Radziwill. ${ }^{\text {s) }}$ But none of these has a first name in the signature. These letters are dated $1748-1771$ and their contents reveal that their author was a confidant of the Prince and plenipotentiary who conducted his affairs at Warsaw. The versatility which Felix Miklaszewicz displayed in America, his connections with the Radziwills, and the conformity of his age with the date given above suggested the hope that he was the author of those letters. This hope vanished however when the character of the writing in the letters at Warsaw was compared with the signatures of Felix on the American documents.

In the same archives are also documents mentioning a certain Anthony Miklaszewicz, born at Mohilow, and Sergeant in the militia of Charles Radziwill in 1760 - 1767 .

These documents determined one fact beyond doubt, namely, that the family of Miklaszewicz was intimately associated with the Radziwills. There must have been some cause which induced Felix Miklaszewicz to name one of his American ships Prince Radziwill. It is, therefore, possible to supply the want of facts as to Felix's past in Poland by suppositions which are historically well founded.

The Radziwill whose memory Felix Miklaszewicz was so anxious to perpetuate in the New World could be none other than Prince Charles, surnamed "Dear Sir."

This magnate was the idol of the Polish nobility, especially in Lithuania, in the beginning of the reign of Stanislaus Augustus. He was the wealthiest man in the Republic, perhaps even in all Europe, and more powerful than many of the reigning princes. He maintained his own militia of 10,000 men and several fortresses. Thousands of armed nobles were at all times ready to answer his summons. He was truly the uncrowned king of Lithuania.

Throughout the long struggle of the Poles banded together in the Confederacy of Bar against the aggrandizement of Russia, Prince Charles Radziwill supported the patriots with money and men.

Felix Miklaszewicz, like many another noble of the northeastern provinces of Poland, must have found himself early within the orbit of the Prince's influence. His excellent handwriting and exact English language on the American documents show that he must have received a good education in Poland. His whole career in America shows him to have been an intelligent and versatile man.

The wanderings of Miklaszewicz prove that, having been induced by the example of the Prince to serve in the Confederacy

3) Born in 1734, died 1790, known in the history of Poland as "Dear Sir" which phrase he frequently used in conversation. 


\section{POLES IN THE REVOLUTIONARY NAVY}

of Bar, he left the country together with his patron when the Confederacy fell. The Confederates dispersed all over Europe. Miklaszewicz shared their fate. Prince Charles helped them financially, though he himself lost much of his fortune through this political upheaval. He even gave material aid to Casimir Pulaski, who at that time sojourned as an exile in France. It is possible that Felix Miklaszewicz also obtained his assistance at that time and so contracted a debt of gratitude toward him.

We may suppose further that, when the news of the American Revolution had reached Europe, Miklaszewicz was either in Germany in the company of the Prince, or in France among the comrades of Pulaski. The noble watchwords of the Revolution lured him to America. How he had come here, or in what year, the author was not able to learn for he found no documents tracing him in the United States before the year 1782; it appears, however, that he had been here previous to that year.

It is difficult to account for the determination of a Polish noble to take to the sea, especially as a privateer. Most probably he at first joined the crew of some privateer through his willingness to serve the Colonies in some capacity or other. On the Continental bond of Prince Radziwill he gave his occupation as "mariner". Since he himself became commander of this vessel proves that he must have possessed some knowledge of maritime warfare. Service on a privateer was perhaps the easiest way of learning the business of a sailor.

In 1778 General Pulaski proposed to the Governor of Maryland to equip a brig for service on the seas, but his proposition came to nought. ${ }^{4)}$ May it not be possible that Miklaszewicz had some part in this proposition?

The successful privateering expeditions of Miklaszewicz earned him so much money that he was able to buy his own vessel and send it to pursue the British, in 1782. This was already after Cornwallis had capitulated at Yorktown. Though the land operations had nearly ceased by that time, the war on the seas was not yet over; the future of the Colonies was not yet certain, and the prospects of peace were still indefinite.

The Continental bond which Miklaszewicz gave on September 5,1782 , in exchange for the letter of marque given to him by Congress is the first American document concerning the Polish mariner. ${ }^{5)}$ From it we learn that this first ship of Miklaszewicz was called the Scotch Trick. It is probable that he bought it second-hand and retained the old name. Miklaszewicz is named as the sole owner of the vessel. Its captain was Joshua Wing of Boston. The bond was subscribed also by Captain Wing and

4) W. Konopczynski, Kazimierz Pulaski, Cracow, 1931, p. 384.

5) Papers of the Cont. Congress, 196, XIV, 18. 


\section{POLAND AND THE AMERICAN REVOLUTIONARY WAR}

Josiah Godfrey, both of Boston. This city is also given as the place of Miklaszewicz's residence.

The Scotch Trick was not a large vessel; it was rather a large boat propelled by oar and sail. Twelve men constituted the entire crew, and two guns and a musket for each of the crew the entire armament. But during the Revolutionary War even smaller vessels served as privateers; some of them having a crew of only several men, and a musket apiece for their only armament. While the large ships numbering up to 150 men in the crew and over 20 guns penetrated far into the ocean, the smaller vessels cruised near the American shores. Sometimes these combined into a flotilla of several vessels and then were a dangerous adversary even to large British ships. At times they attacked them unexpectedly by night, at other times they dared an open attack, bringing their prey triumphantly into the ports.

As may be judged from her dimensions, the Scotch Trick also performed this coast service. We do not know how she fared. We may suppose, however, that she acquitted herself well and, despite the late season and her small tonnage, she pursued the English vessels on the coast of New England, or New York, or she descended southward even as far as Chesapeake Bay. She may have brought valuable booty to its owner so that not only were the members of the crew well rewarded, but the proprietor was encouraged to think of the equipment of a larger vessel.

But varied are the fortunes of war. It may, therefore, have happened that the Scotch Trick had fallen into the hands of the British and her owner sought vengeance. Whatever may have been her fate and his motives, this at least is certain that Miklaszewicz appeared before the Council of the Colony of Massachusetts Bay, March 18, 1783, and as proprietor and captain of another vessel he applied for commission "to cruise against the enemies of the United States."

The Council settled such matters with dispatch and Miklaszewicz received his letter of marque on the same day. ${ }^{6)}$

From the original documents in the Library of Congress 7) and from those in the Archives of Massachusetts at Boston ${ }^{8)}$ we learn that Miklaszewicz gave Continental and State bonds, each for $\$ 20,000$, as was the practice at that time. He, however, was not the sole proprietor of the new vessel. The other owners were Samuel Dogget and Max Myers, both of Boston, whom he had evidently gained to his plans and financial assistance. Caleb Coolidge and John Cause subscribed the bonds as witnesses.

The new vessel of Miklaszewicz was a two-masted schooner much larger than the first, better armed and with a larger crew; she had 6 guns, 2 mortars, and muskets for a crew of 15 men.

6) Massachusetss Soldiers and Sailors in the Rev. War, X, 728.

7) Papers of the Cont. Congress, 196, XII, 18.

8) Mass. Arch., vol. 172, p. 313. 


\section{POLES IN THE REVOLUTIONARY NAVY}

And although Massachusetts was her native land and the Stars and Stripes streamed from her mast, the old Confederate of Bar longed to give the schooner some stamp to designate his national origin. Bearing in mind his former dependence on Prince "Dear Sir," Miklaszewicz christened his schooner Prince Radziwill.9)

And thus it came about that a Polish noble, once a companion in arms to Pulaski, sailed the high seas as commander of a manof-war to fight for the liberty of America.

The Prince Radziwill put out to sea to serve like her predecessor, but the news of an armistice between the United States and England soon interrupted her activity. The armistice was signed on January 20, 1783, but the Continental Congress learned of this first on March 24. On the following day Robert Morris, the Agent of the Navy, gave orders recalling all the armed vessels cruising under the commissions of the United States of America. Before this order reached all the vessels on the sea at least another month elapsed.

The expeditions of the privateers during the Revolution left but few historical traces. Their logs perished nearly completely as the captains did not care to preserve them. Consequently, it is impossible to reconstruct the Revolutionary career of Miklaszewicz and his vessels more accurately.

What did Miklaszewicz do with his small flotilla after the war? He probably followed the example of the majority of privateers in starting on a business career. The years following the Revolutionary War were remarkable for the greatest expansion of the American merchant marine. It is possible, then, that among those vessels which cruised the seven seas under the American flag there was also the veteran of the Revolutionary War, the Prince Radziwill, under command of a Polish captain.

The next trace of Miklaszewicz we find in the South. The Annals of Georgia contain references showing that he transacted there some financial matters with the Puritans from South Carolina who had settled in Liberty County. His name appears frequently among the records of property deeds of that county, though with a different spelling, as, De Miklasiewith, De Miklasruveitz, de Miklaszerwene. ${ }^{10)}$ These references cover the decade from 1785 to 1795 and indicate that he was quite wealthy.

At the first census of the United States, in 1790, he resided at Charleston, S. C., in the territory of St. Philip's and St. Michael's Parish, and his household consisted of "two free white males over sixteen years old, one free white female and two slaves."10a) It is probable that Miklaszewicz spent the remainder of his life in Charleston.

9) In the documents Radziwill is wrongly spelled with a single "l."

10) E. P. Wilson, Annals of Georgia, vol. I, p. p. 48, 63,65 .

10a) Dept. of Commerce and Labor, Bureau of Census, Heads of Families at the First Census of the U. S. taken in the year 1790, South Carolina, p. 43. 


\section{POLAND AND THE AMERICAN REVOLUTIONARY WAR}

These few facts which history has preserved about Miklaszewicz suffice to make possible an estimate of his services to the United States. Some American historians accuse the privateers of working for personal gain. The expectation of profit from the prizes did, indeed, influence them. But "our privateers" says their historian, E. S. Maclay, "supplied a very considerable, if not a supremacy of, sea power for the struggling colonists toward the close of the Revolution, and were the means of transporting munitions of war and money across the Atlantic..... Had it not been for our privateers, the Stars and Stripes would have been, for all practical purposes, completely swept from the seas. It was the astonishing development of this form of maritime warfare that enabled the struggling colonists to hold their own on the ocean...."11)

Gardner W. Allen also concedes that "valuable service to the country was rendered by the privateers, and they contributed in a large degree to the naval defense, and so to the fortunate outcome of the war." 12)

Still more highly were these services appraised by Commodore Herbert Hartley in an essay "Down to the Sea in Yankee Ships." 13) "With all due respect to John Paul Jones," he says, "privateering did more to help us win the Revolution than the heroic efforts of our tiny Navy."

The expeditions of Miklaszewicz are the more noteworthy because he ventured these at the end of the Revolutionary War when "privateers were few in number, the risks of venturing greatly increased." 14)

\section{HRABOWSKI, SAMUEL}

One of the purveyors for the American Revolutionary navy was a Pole, Samuel Hrabowski, a merchant of Charleston, S. C.

As no Polish heraldry book contains the name of Hrabowski, we may assume that he was of common origin, or what seems more probable, that Hrabowski was only a variation of the popular Polish noble name Grabowski to conform with entries in some important English or American documents.

The nationality of Samuel Hrabowski is beyond doubt. The memorial of his widow, Ann, deposited at London, January 13, 1787, together with the memorials of American Loyalists asking indemnity for the losses suffered by them during the Revolutionary war, plainly states: "Mr. Hrabowski was a Pole by birth." 15,

11) E. S. Maclay, A History of American Privateers, N. Y., 1899,p.206

12) G. W. Allen, A Naval History of the Am. Rev., Boston, 1913, p. 48.

13) American Legion, Oct., 1930.

14) Charles Lincoln, Naval Records of the Am. Rev. in the Library of Congress, Wash., 1906; Prefatory Note.

15) W. W. Siebert, Loyalists in East Florida, 1774-1785, Deland, 1929, II, $130-132$. 


\section{POLES IN THE REVOLUTIONARY NAVY}

The memorial, however, does not mean that Hrabowski was a Loyalist.

The memorial describes the activities of Hrabowski in America in detail. He came to England from Poland in the sixties of the 18-th century, perhaps as an exile in consequence of his participation in the Confederacy of Bar. It is possible that he had a wife in Poland who came after him, or, what is more likely, that he married in England.

By the treaty of 1763 Spain ceded Florida to England. The new proprietors strove to improve the conditions in the colony and to encourage new immigrants thither by making various concessions. Hrabowski was among those who decided to seek their fortunes in the province. He immigrated to Florida with his family in February, 1770, and settled in St. Augustine, the oldest and principal city of the colony. He was then the first known Polish settler in the confines of the present State of Florida.

He came not without some means. Soon after his arrival, August 7, 1771, he bought a house and lot situated at No. 2 Spanish St., in Box's Quarter, for a hundred and fifty pounds.

Hrabowski improved this possession to a large extent. $\mathrm{He}$ rebuilt the old house, erected a new one beside it, and drilled a well of good drinking water. He planted the rest of the lot with an orange orchard. In a few years his farm more than idoubled in value and was priced at three hundred and fifty pounds.

He also received from Governor Moultrie a grant of a hundred acres of land on St. John's River, about 48 miles from St. Augustine, January 1772. He planned to settle there himself or to secure someone else as a tenant, but he soon changed his plans. He left Florida in $\mathbf{1 7 7 3}$ with his wife and son for Charleston, S. C. It was then one of the most populous and most commercial cities of the English colonies; its commerce was principally in the hands of foreigners; these conditions and the hope to better his financial position probably caused him to change his former place of abode.

Not finding a buyer for his possession in St. Augustine, or, maybe, in the hope of returning there sometime, he left it in the care of a lawyer, named Payne. As to the grant on St. John's River, Mrs. Hrabowski testified in 1787 that "she never saw the Land and her Husband laid out no money upon nor made any Settlement upon it."

Hrabowski became a merchant at Charleston. It seems that he conducted a store of marine supplies and soon attained to some prominence in the city, as is attested by mentions of him and his family in the local South Carolina and American General Gazette and its successors.

Soon after the Revolutionary War broke out. Charleston fell into the hands of American patriots and remained in their possession till 1780, when the British captured and kept it until the close of the war. 


\section{POLAND AND THE AMERICAN REVOLUTIONARY WAR}

What was the attitude of Hrabowski toward the war?

Circumstances attest that he took the side of the Whigs, though he did not actually bear arms. His early death might point to a bad state of his health. His presence in the city governed by Whigs, is a sufficient evidence in itself that he did not sympathize with the Tories. An additional proof of his loyalty to the American cause is the fact that he became the purveyor for the South Carolina Revolutionary navy. The Journal of the Commissioners of the Navy of the South Carolina ${ }^{16)}$ contains several entries mentioning transactions of the Commissioners with Hrabowski. Thus a meeting of the Board, February 6, 1777, approved the bill of Hrabowski for 132 pounds for various supplies for the vessels. ${ }^{17)}$ A special meeting of the Board, May 14, 1777, also approved his bill for 341 pounds for rum and barrels. ${ }^{18 \text { ) }}$

The incomplete state of the Revolutionary documents allows the supposition that he also arranged other deliveries for the American forces.

His activity was cut off by his death, September 7, 1777, which was annouced by General Gazette. ${ }^{19)}$ He died still a young man. His widow, Ann, was then 29 years old and the only son, John Samuel Hrabowski, was still a minor ten years later, when Mrs. Hrabowski presented the memorial to the London authorities.

The widow carried on the business and lived to see the independence of the United States.

The war brought her heavy financial losses. When the Spaniards reoccupied Eastern Florida in 1781, and confiscated the estates of British citizens, her possession in St. Augustine was also taken and sold at auction for two hundred dollars, much below its actual value. Her land on St. John's River was forfeited too. The confiscation shows that Hrabowski naturalized himself as a British citizen in America before the Revolutionary War, or perhaps even in England before his departure for Florida. But the act of forfeiture was illegal, as the Hrabowskis were citizens of the United States, an ally of Spain, at that time.

Mrs. Hrabowski tried to get redress at London after the war. She even personally sailed there to present the aforesaid memorial to the British Government.

She returned to Charleston, probably unsuccessful. The Deed Book of Richmond County, Georgia, mentions her October 22,1790 , when she made her son plenipotentiary to collect a debt from William Graves of Wilkes, Ga. ${ }^{20)}$ Evidently, John Samuel

16) Edited by A. S. Salley, Columbia, S. C., 1912.

17) Journal of the Comm. of the Navy, p. 39. Hrabowski's name is spelled Hrabowsk.

18) Ib., p. 65.

19) So. Carolina Hist. and Gen. Mag. XVII, 126.

20) Hist. Coll. of the Georgia Chapters D. A. R., II, 228. 


\section{POLES IN THE REVOLUTIONARY NAVY}

Hrabowski had reached full legal status in the meantime.

According to the first census of the United States taken in 1790 , Mrs. Hrabowski resided in the territory of St. Philip's and St. Michael's parish, in Charleston, and her household consisted of "one free white male over sixteen", evidently her son; "one free white male under sixteen, two free white males and three slaves." 21)

The City Gazette of April 15, 1794, announced that "on Thursday evening Mr. John Samuel Hrabowski, merchant, married to Miss Ann Swanson of Belville". ${ }^{22}$ )

Mrs. Hrabowski did not long enjoy the happiness of the young couple. The City Gazette of January 27, 1798, notes:"Died on the 23rd instant, in the 51st year of her age, much lamented by her relatives and acquaintances, Mrs. Ann Hrabowski, many years a very respectable inhabitant of this city." 23)

21) Dept. of Commerce and Labor, Bureau of Census, Heads of Families at the first Census of the U. S. taken in the year 1790, South Carolina, p. 42.

22) So. Carolina Hist, and Gen. Mag. XXII, 69.

23) Ib., XXV, 28. - The names of other supposed Poles who served in the American Revolutionary Navy are given in the foregoing chapter. 


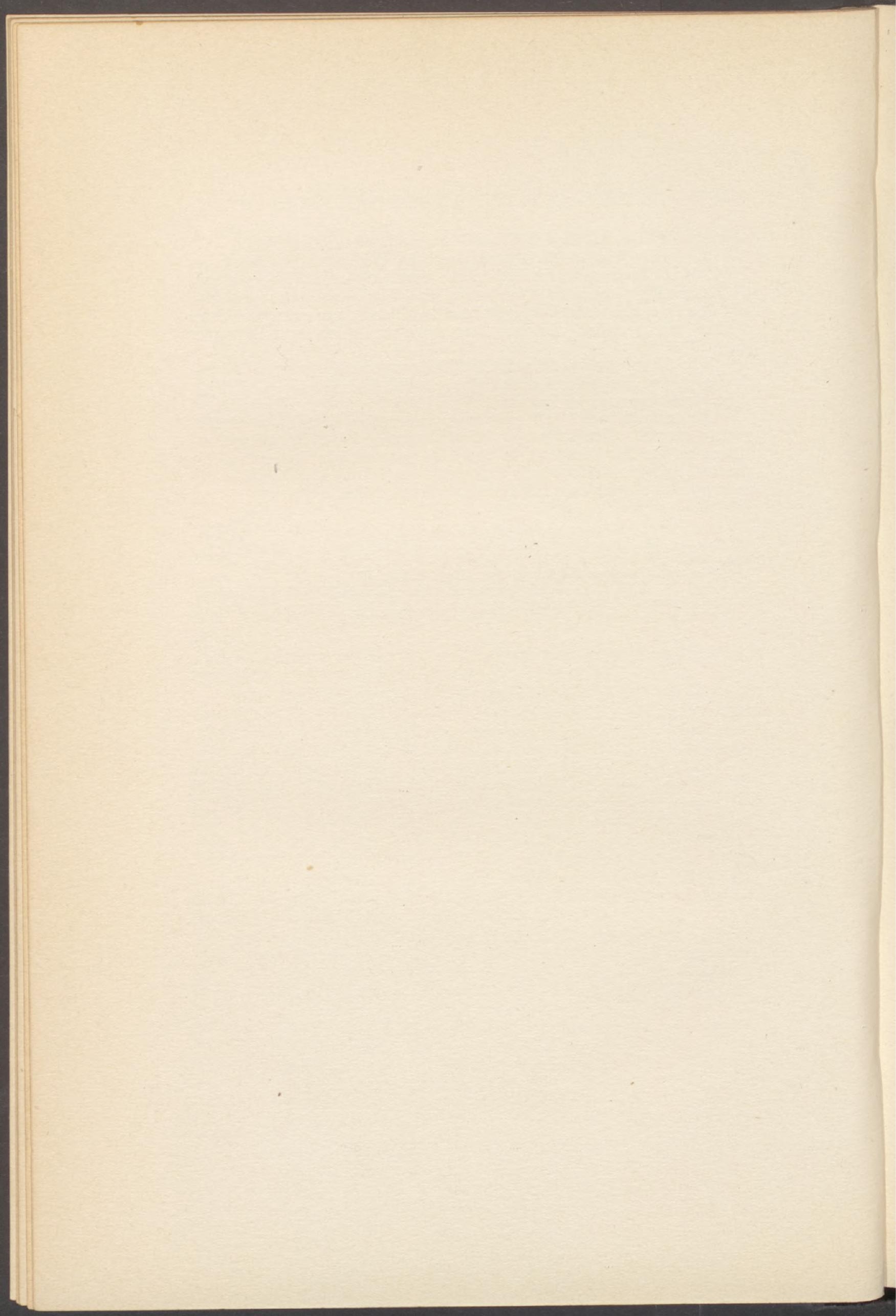




\section{VI. \\ POLES IN THE LEGION OF THE "POLISH PRINCELING"}


Besides the American Continental army, the militia and privateering, there was yet another field in which the Poles fought for the independence of the United States, namely, the French army which the unhappy King Louis XVI sent to America in 1780 .

The official register of the French officers and soldiers who served in the American Revolutionary War does not show any Polish names for the reason that it omits from its records that corps in which the Poles served. 1) This is due to the fact that this military body was not under the orders of the French Ministry of War but under that of the Navy. It was the Legion of the Duke de Lauzun.

At that time of professional soldiery it was a common practice among the nobility and aristocracy of Europe to serve in foreign armies merely for the sake of the honors which could be gained there. There were many Poles, some even renowned in history, who served in the French army at the end of the 18th century. It is not extraordinary, therefore, that they served also in the Legion of Lauzun, especially since General Armand Louis de Gontaut Biron, Duke de Lauzun, was known to Poland and to the Poles.

Driven by his love of adventure the Duke more than once visited Poland. He even tried to become French ambassador at the court of Warsaw. These escapades earned for him the nickname of the "Polish Princeling" and the sportive recasting of his name into the Polish form "Lozanski."2) But he also gained the friendship of some of the Polish nobles who, like the Duke, were ready for pleasure or for a fight. Lauzun in turn liked them with all the sincerity of his chivalrous, though too frivolous, nature.

After his carefree sojourn on Polish soil, the Duke was obliged to abandon his life of gayety. Having been sent to Senegal by the French King, he behaved there so gallantly that on his victorious return he was rewarded with the command of a separate corps organized especially for service in the colonies.

This corps, known in American history as the Legion of Lauzun, was officially called Volontaires Etrangers de la Marine. As may be deduced from the name, it was composed of volunteers from foreign countries. Thomas Balch states in one place that its soldiers were mostly Germans, in another that they were Hungarians. ${ }^{3)}$ The fact very probably is that they were of

1) Les Combattants Francais de la Guerre Americaine, 1778-1783, 58-th Congress, 2-nd Session, Document 77. $39-53$.

2) Simon Askenazy, Wczasy Historyczne, Warsaw, 1902; vol. I, p. p.

3) Thos. Balch, The French in America during the War of Independence, I, 29-30; II, 160-163. 


\section{POLAND AND THE AMERICAN REVOLUTIONARY WAR}

various nationalities. The same is true of the officers. But the greater percentage of them were French.

Three of the officers of that corps were Poles, namely: Capt. John Kwiryn Mieszkowski, Commander of the Second Squadron of the Hussars; Lieut. Count Michael Grabowski, of the same Squadron, and Lieut. George Uzdowski of the First Squadron of Hussars. ${ }^{4)}$ Another officer of that Legion was Major John Poleresky, written also Polericsky, a Pole according to some authorities, but really a Polish-Hungarian. Each of these officers belonged to the flower of the French army.

The papers of the Duke de Lauzun and the documents in the historical and administrative archives of the French Ministry of War at Paris contain quite abundant information concerning Capt. Mieszkowski. From those sources we learn that he was born of a noble family in Karczew, Poland, March 30, 1744. At twenty-two he enlisted as a volunteer in the French Regiment de Conflans. He was promoted to the rank of Lieutenant in the same regiment March 1, 1767.

During his service in France Mieszkowski became united by bonds of friendship with the young and elegant de Lauzun. Time tightened these bonds. "The Pole became devoted to him body and soul." 5) Lauzun mentions him in his memoirs as messenger to his sweetheart in Poland ${ }^{6)}$.

With de Lauzun Mieszkowski made the campaign in Senegal in which he acquitted himself so well that the King made him Chevalier of the Order of St. Louis, June 25, 1779. On the eve of his departure for America he was commissioned Captain Commander, Capitaine-commandant, of the Second Squadron of the Hussars of the Legion of Lauzun, April 1st, 1780.

French documents regarding Count Michael Grabowski are rather scant. The record of service written by himself in 1814 and now in the administrative archives of the French Ministry of War does not mention the place and date of his birth. There are many noble families of that name in Poland, but the title Count allows the supposition that he was a relative of John Grabowski, Major-General of the Polish Army, whose widow was secretly married to King Stanislaus Augustus in 1784.

Grabowski entered the French service in January, 1774, as a volunteer in la Legion royale. He was transferred to the Regiment of Royal Dragoons in 1776, and commissioned Second Lieutenant the following year. On November 1,1778 , he was appointed Second Lieutenant, Lieutenant en second, in Volontaires Etrangers de la Marine. He took part in the expeditions against Gersey in 1778 and at St. Malo in 1779.

4) Viscount de Noailles, Marins et Soldats Francais en Amerique, 1778-1783, Paris, 1903, p. 416-420.

5) Le Duc de Lauzun, General Biron, Correspondance Intime, 17911792, Paris 1906, p. 31.

6) Memoirs of the Duke de Lauzun, London, 1928, p. 104. 


\section{POLES IN THE LEGION OF THE "POLISH PRINCELING"}

Lieutenant George Boncza Uzdowski was born in Warsaw, April 29, 1754. He began his French service in the same la Legion royale, but a year later than Grabowski.

The archives of the French Ministry of War do not contain the service record of Major John Poleresky, but his participation in the Revolutionary War is affirmed by American documents. His name is written variously, but for the most part in the form given above. The Vital Records of Rhode Island, 1636-1850, mention him as "Major John Poleresky, born in Poland, officer in the American Revolution." 7) Balch also calls him "a Polish Officer."8) But other sources give France as his birth place, 9) and evidences favor the opinion that he was a member of a PolishHungarian family.

For want of space on the ships, only the cavalry of the Legion, about six hundred men, took part in the expedition. These embarked at Brest in May, 1780, together with the rest of the French army, and after a fatiguing voyage of seventy days, they arrived at Newport, R. I. The Americans welcomed them with joy. Then followed feasts and amusements, the opening of private and official relations, and amid these entered the labors of allocating the army and of fortifying Rhode Island. Lauzun's Legion occupied at first the exposed position at the Neck peninsula, but in November the men were sent to Lebanon, Conn., for winter quarters.

The conduct of the Legion there evoked high praise from Gov. Trumbull and from the inhabitants. On March 5, 1781, Washington visited Lebanon on his way to Newport, spent three days with the Hussars, and "highly complemented the Legion and its Commander on their appearance nad discipline."10)

One of the Polish officers of the Legion evidently accompanied Washington to Newport where the American General conferred with Gen. Rochambeau on the plans of future action. There the whole French army paraded in review before Washington who went bareheaded through their ranks with Rochambeau at his left side. "French nobles, commanders and their subaltern officers went behind them. Count Rochambeau was a small, ingenious looking man.... A Prussian Baron and a Polish Count, both officers of high grade in the French army, marched just behind," recounts an eyewitness of this parade.11)

During the march of the French to the Hudson, and again during the progress of the united armies towards Yorktown, the

7) Vital Records of R. I., ser. I, vol. XXI, p. 478.

8) Thos. Balch, The French in America, vol. II, p. 201.

9) Reports of Committees, 36-th Congress, 2-nd Session, House of Repr., March 2, 1862; Charles E. Allen, History of Dresden, Me., p. p. 441447.

10) O. D. Hine, Early Lebanon, Hartford, Conn., 1880, p. 64.

11) E. M. Stone, Our Frenc: Allies, Providence, 1884, p. 363. 
Legion "rendered great services." 12) It was the only cavalry of the allies. It protected the marching columns against the British occupying New York. It saved Gen. Lincoln's detachment from being cut off in action at Fort Knyphausen, N. Y., June 30, 1781. In the victorious skirmish at King's Bridge, July 3, Maj. Poleresky lost his valuable horse. ${ }^{13)}$ When Washington made a long reconnaissance before New York, he chose the Hussars of Lauzun as his companions. During the latter part of the march through New Jersey, the Legion "always watched with indefatigable zeal over the safety of the army, either clearing the road, protecting the flanks, or guarding the rear." 14)

During the siege of Yorktown they were the "first of all the army to have the chance to show their brilliant courage." 15) In the skirmish with Tarleton at Gloucester, October 3, 1791, the Hussars of de Lauzun routed the Britishers who were three times stronger, and Tarleton himself fled ingloriously after having nearly lost his life.

In this skirmish Capt. Mieszkowski distinguished himself by exceptional bravery. The French King sent him for this a commendatory letter and an award of 400 pounds, besides 800 pounds, for the lost horse. ${ }^{16)}$

If the Legion's "services at Yorktown were of inestimable value in defeating Tarleton, the relentless legionary plunderer of Virginia,"17) it was also due to the merits of Capt. Mieszkowski, as also to the bravery of his Polish countrymen in the French army. On October 19, 1781, these brave Poles had an opportunity of witnessing the surrender of Cornwallis with 8,000 men, 214 guns and 22 banners.

After the victory of Yorktown, the Legion occupied winter quarters at Hampton. Here it rested but a short time, for Rochambeau sent it to the boundary of North Carolina to support the action of General Greene who was still fighting in the South.

The Legion was the last detachment of the French army to leave America. On the eve of their departure from Wilmington, Del., May 12, 1783, Washington bade them farewell in a message to the Duke asking to express "to all the brave officers and soldiers of your corps the high esteem I have for them and the regard I shall ever entertain for their service in the cause of the United States, to whose independence and establishment as a nation they have contributed a noble share."

12) Thos. Balch, The French in America, vol. II, p. 29.

13) Reports of Committees, H. R., 36-th Cong., 2-nd Sess., March

14) Thos. Balch, The French in America, vol. I, p. 173.

15) Ib., vol. II, p. p. $160-163$.

16) Admin, archives of French Ministry of War.

17) De B. Randolph Keim, Rochambeau, Wash., 1907, p. 504. 


\section{POLES IN THE LEGION OF THE "POLISH PRINCELING"}

All American historians agree that the success of the Revolution would be impossible without the assistance of the French army. The French detachment which was most active during the whole campaign of 1781, which gained most glory and which rendered most useful service to the allies was the Legion of the "Polish Princeling," commanded partly by Polish officers.

It is regrettable that more documents are not accessible to represent more fully the nature of their services in America. That Lieutenants Grabowski and Uzdowski also acquitted themselves of their duty with singular honor may be judged from the fact that after their return to France, October, 11, 1783, both officers were given commissions of First-Lieutenants -Lieutenants en premier.

It now remains to ascertain the lot of each of these officers after the termination of the war.

Major John Poleresky was one of those French officers who remained in America. "After the war was over, and our independence as a nation secured by the aid of our French allies, he remained in this country, took the oath of allegiance, and became a citizen of the United States. He was entitled to a pension from the King of France of 100 louis d'or per annum, until the proclamation of Napoleon I. In consequence of the proclamation, and of his failure to return to France, he was deprived of his pension, and his property to a large extent was confiscated.... He was married in Pownaldsboro, Maine, on the 22 day of June, 1785, to Nancy Pochard, by whom he had several children.... The said Major Poleresky sustained an excellent moral character, as appears from numerous certificates of the selectmen of the town where he resided, but possessed little property for the support of himself and family, and died on the 8th day of June, 1830, leaving the said Nancy Poleresky a widow, and she remained such widow until 1849, when she died...." 18) Poleresky was the first clerk of the town of Dresden, Me., which office he held for a quarter of a century.

Captain John Kwiryn Mieszkowski returned to France. Having always shared the lot of his commander, Duke de Lauzun, he became his adjutant and attained to the rank of Brigadier General, Marechal de camp. When the French Revolution broke out, Lauzun supported it and Mieszkowski served with him first in the Army of the Rhine, then in Italy. But de Lauzun had the misfortune of incurring the suspicions of the Revolutionary authorities. The gallant leader of the Legion was beheaded in 1793. This was the lot of many other French heroes of the American Revolution. Mieszkowski escaped the fate of his commander, but was dismissed from the army. He survived the French Rev-

18) Reports of Committees, 36-th Congress, 2-nd Session, House of Repr., March 2, 1862. 


\section{POLAND AND THE AMERICAN REVOLUTIONARY WAR}

olution as also the reign of Napoleon, and died at Vassy, France, February 27, 1819, at the age of 75 .

Lieutenant Count Michael Grabowski, later promoted to the Captaincy of the Second Chaussers, was de Lauzun's adjutant during the French Revolution. Lauzun's death spelled also the ruin of his own career. French documents state only that, having been dismissed from the army, he still resided in Paris in 1814.

Captain George Uzdowski died from a bullet wound suffered during the street riots at Nancy, August 31, 1790. He became one of the first victims of the French Revolution.

All three Poles left very honorable records in the history of the French army. Gen. Baron de Heymann in his report of the inspection of the Regiment of Hussars de Lauzun, September 2, 1786, notes as follows:

"Capt. Mieszkowski, Commandant, a distinguished officer who deserves promotion.

"Capt. Grabowski, a highly intelligent officer."

The same General made another inspection of the Regiment, September 12, 1787, and again paid high tribute to these men in his report: well." 19)

"Capts. Uzdowski and Grabowski performed their duties

It is possible that there were still other Poles in the ranks of the Legion of Lauzun. However this may be, it is a fact worthy to be remembered that the Poles were also in the army of Rochambeau. Whether under the Stars and Stripes or under the Lilies of the Bourbons they "contributed a noble share to the independence of the United States and to her establishment as a nation."

19) All biographical datas of these three officers were taken from the administrative and historical archives of the French Ministry of War at Paris, furnished the author by General Paul Azan, Chief of Historical Service. 


\section{VII.}

\section{MAJOR ELHOLM, THE CHAMPION OF POLISH AND AMERICAN LIBERTY}

Was he a Dane, a German, a Pole, a Frenchman, a Swede or a Norwegian? 

The war for American independence attracted to these shores warriors from several European countries. Among these there is one who was a participant in the Confederacy of Bar, in Poland, a companion of Pulaski on both hemispheres, also a co-founder of a Commonwealth to which the present State of Tennessee is a successor - Caesar August George Elholm, or as called by some historians, Augustus Christian George Elholm.

As he signed the original roll of members of the Order of the Cincinnati as "A. C. G. Elholm," the latter names were probably used mostly by him in America.")

The national origin of this eminent Revolutionary soldier is a riddle. Having been attracted by references in some historical works that Elholm was a Pole and confronted by several other theories as to his nationality, the author has made a thorough study of the question and considers himself able to give an answer which seems to have chances of historical truth.

The only American contemporary document which mentions Elholm's past in Europe plainly states that he, if not a Pole, was an arrival from Poland. Noted historians, who were in actual contact with the period of the Revolutionary War, considered him a Pole, though one of them was undecided whether Elholm was a Pole or a Frenchman. Not until a half of a century after Elholm's death did there appear a new theory asserting that he was a Dane. Still more recently the German-American historians have attempted to prove his German origin.

As far as the author was able to investigate these claims, he found that George White of Georgia was first to deny in print the Polish nationality of Elholm and substitute it by the opinion of his Danish origin. In his work Historical Collections of Georgia, 1a) in a brief sketch of his life White calls Elholm "a native of Holstein, Denmark." Another historian of the State of Georgia, J. K. Tefft, supports this theory, though only privately, and in this same direction argues a contemporary historian, Samuel Cole Williams, author of the History of the Lost State of Franklin. Let us therefore examine these claims for their authority to Elholm's Danish nationality.

Tefft's letter to the late Kentucky historian Lyman C. Draper seems to establish definitely the origin of this theory. This

1) He was a member of the South Carolina State Society of the Cincinnati. He has never been represented in the Order. (W. S. Thomas, Mernbers of the Society of the Cincinnati, p. 57.)

1a) New York, 1854, p. 626. 


\section{POLAND AND THE AMERICAN REVOLUTIONARY WAR}

letter is found in Draper's collection of manuscripts in the archives of the State Historical Society of Wisconsin at Madison. ${ }^{2)}$

Draper was making inquiries from Tefft about Elholm. Tefft in his reply from Savannah, Ga., May 10, 1855, writes: "It is stated that he was a native of the Duchy of Holstein, Denmark." The authority for this information was perhaps either a certain Judge Berrien of Florida mentioned in this letter, who in his youth had a passing acquaintance with Elholm, or, what seems more probable, a neighbor of Tefft, a Major McIntosh, son of Lt. Col. John McIntosh of the Revolutionary Army, with whom Elholm fought a duel in 1779 or in 1780 .

Tefft adds at the end of this letter: "I am enclosing a copy of a paper (concerning the biography of Elholm) furnished by my neighbor and friend, Major McIntosh to the Rev. Geo. White for his Historical Collections of Georgia".

This sentence proves that White, in stating in his history that Elholm was a Dane, relied on the recollections of McIntosh. The story of Elholm's Danish nationality originated most likely with McIntosh. It also is likely that Major McIntosh had heard of a Dane named Elholm directly from the mouth of his father, but it is just as probable that he gained this information from others. Even were the first assertion true, his opinion cannot be a deciding historical factor. The average man seldom remembers well the incidents of his personal experience after a lapse of fifty years; for a much greater reason does he fail to be an absolutely reliable witness to occurrences known to him only from the recitals of others.

The Danish-American history, meager as it is, makes no mention of Elholm. The author, at least, has not found any reference to him in the largest historical work of this kind by P. S. Viga Danske and Kamp and Og for Amerika, ${ }^{3)}$ in which all the more prominent Danish participants in the American War for Independence are listed. Neither is there an Elholm in the Danish biographical dictionary Dansk Biografisk Haandleksikon.

Mr. Hauch-Fausboell, director of the Danish Institute of Genealogy in Copenhagen, disproves this theory of the Danish nationality of Elholm. The author of this present investigation has requested him, through the courtesy of the American Consul General of Copenhagen, Hon. N. Winship, for his opinion on the possibility of Elholm's being a Danish name.

Mr. Winship informed the author by letter dated June 3, 1931, as follows:

"Regarding your inquiry concerning the nationality of Major Caesar (Augustus) Elholm.... this office applied to the Danish

2) Draper's Collection, $6 \times \times 66$.

3) Omaha, Neb., 1917. 


\section{MAJOR ELHOLM}

Genealogical Institute, the director of which Mr. Hauch-Fausboell courteously promised to look into the matter.

"Mr. Hauch-Fausboell telephoned this office today that his search through the archives of the Danish Army and old Probate Records of this country has failed to reveal any person by the name of Elholm. Mr. Hauch-Fausboell stated that it may safely be asserted that the name of Elholm is not Danish, and that no person by that name has served in any official capacity in Denmark."

Neither has the author found any other document which could directly support the theory of the Danish nationality of Elholm. In face of the absence of any documentary evidence on this point, and of the opinion of the Danish authority mentioned above, the said theory must be considered unfounded.

As to the theory of Elholm's German origin, the author finds it to be of a more recent date and still less founded. Mr. A. B. Faust, the German-American historian, when speaking of Sevier, the founder of the State of Franklin, in his work The German Element in the United States, ${ }^{4)}$ states that his Adjutant-General, Maj. Elholm, was a German. As a sole proof of his statement he quotes the article of J. A. Wagener in the German-American periodical Der Deutsche Pionier, vol. II, 1870, p. 368. This article entitled "Frankland und Franklyn" narrates the history of the short-lived State of Franklin and limits itself to a bald statement of the "German Major Elholm". Wagener gives neither documentary evidence nor historical data in proof of his theory of Elholm's German nationality.

A strong suspicion naturally arises that the German-American writers were laying an unfounded claim to Elholm. They were apparently misled by White; since he mentioned that Elholm had come from Holstein, and Holstein was under German rule since 1864, General Wagener considered himself authorized to claim Elholm as a German. Faust, who has written his history of German emigration already in our times, had a precedent to follow in his claim.

On apparently this same foundation of doubtful assertions by historians and on the temporary German rule over Holstein, Francis B. Heitman in his Historical Register of Officers of the Continental Army during the War of the Revolution, gave Germany as the mother country of Elholm. ${ }^{5)}$

But neither his name, nor the doubtful statement that he was born in Holstein, nor any other known fact of his life, connects Elholm with Germany. There exists only the possibility, not supported however by any evidence, that he served in the army of Frederick the Great, but this cannot have any influence on the question of his nationality.

4) New York, 1927, vol. I, p. p. $369-370$.

5) Washington, 1914, p. 214. 


\section{POLAND AND THE AMERICAN REVOLUTIONARY WAR}

In as much as the theory of the Danish origin of Elholm had certain marks of probability, in so much the more the theory of his German nationality must be considered pure fiction until such time in which the German-American historians will submit suitable evidences.

Hon. Samuel Cole Williams in his History of the Lost State of Franklin, 6) a work well written and very interesting, necessarily had to occupy himself with the person of Major Elholm. He agrees, in one instance, with White (page 301) that Elholm "came from the Duchy of Holstein, which at that time belonged to Denmark," but, in another, settles the matter by a compromise claiming him to be "a German-speaking Dane" (page 108). For his authority the writer cites the history of Faust, the article of Wagener, and the well-known opinion of White, ignoring at the same time the very contradictory opinions of other historians.

The author has addressed himself in this matter to Judge Williams of Tennessee, who in a letter dated March 2, 1931, acknowledged that in this matter he relied entirely on the sources which he quoted, but, he added, "his primary concern with Elholm was the part he took in the State of Franklin, and not his nativity."

The theory of Polish descent of Elholm has, in fact, more probability than the two foregoing ones.

The Rev. White himself, who on page 628 of his Historical Collections of Georgia calls Elholm a Dane and is the first to propagate the theory of his Danish origin, thus speaks of him on page 547 of that same work: "Captain Elholm, a Polander in the American service." This is really a detail in Elholm's friction with Lt. Col. McIntosh, one which White had received from "a certain honorable friend", but the latter had obtained it perhaps from an eyewitness at that duel. It is, at any rate, as important a testimony as that of the son of McIntosh, who told White that Elholm was a Dane.

The first to give Elholm's nationality in printed form, as far as this author could find, was J. G. M. Ramsey. a historian of the State of Tennessee. In his work The Annals of Tennessee, ${ }^{7)}$ he writes on page 381 that "Elholm was a Frenchman or a Polander". As to Elholm's French nationality it is not supported by any other opinion nor by any documents. The uncertainty of Ramsey is solved by William Bacon Stevens in his History of Georgia, ${ }^{8}$ ) where in the second volume, page 381 , edited at a later date than the work of White, he speaks of Elholm as "a Pole by birth". Stevens was professor of History at the University of Georgia, and therefore no less qualified for historical research than the Rev. White, or Tefft himself.

The most conclusive proof for the claim that Elholm was a Pole, or that, at least, he came to America from Poland, is an

6) Johnson City, Tenn., 1924.

7) Charleston, 1853; reprint Chattanooga, 1926.

8) New York, Philadelphia, 1847-1859. 


\section{MAJOR ELHOLM}

original letter dated August 20th, 1788, found also in Draper's collection in the archives of the State Historical Society of Wisconsin. The writer of this letter was a member of "Tipton's party", hostile to Franklin, a State which had existed for a brief period in the northern part of what is today Tennessee. Elholm, who was at that time the right-hand man of John Sevier, the leader of the "Franks", was an ardent friend of this new State.

This member of Tipton's party, whose name is not given, wrote as follows: "As to Major Elholm, thare need be no more said of him, then, that the cause of his coming to Americe was his Joining to depose the king of Poland for his granting a free toleration in religion to his subjects, that he sacrificed his native Country, his fortune, and his friends to his ambition once, and tharefore is not to be trusted...." 9)

That in the storm of political struggle a member of the opposing party should not be at all enthusiastic about Major Elholm, is entirely natural and requires no explanation. But the letter discloses important details: In the first place, it makes known the fact that Elholm was a participant in the Polish Confederacy of Bar. That movement, namely, "his joining to depose the King of Poland for his granting a free toleration in religion to his subjects", can be nothing else but the Confederacy of Bar, which originated from a controversy regarding the "dissenters" and ended in an attempt to capture King Stanislaus Augustus Poniatowski. "He sacrificed his native country, his fortune, and his friends to his ambition once" may be taken to mean that Elholm left Poland and went into exile after the failure of that Confederacy.

The fact that Elholm on arriving in America immediately sought out Pulaski and offered to serve under him, confirms all that has been said above. Beyond that we may only add that according to a Polish proverb, one's neighbor knows best how one is prospering. Elholm was widely known in Franklin and there was perhaps no one among the settlers, neither among the members of his party, nor again among those opposed to the new State, who would not be well acquainted with his person. The anonymous member of the opposing party of Tipton, could not be the only one who considered him a Pole; this opinion must have been universal among those who came in direct contact with him at that time. And, if he was universally considered a Pole, then undoubtedly he himself must have acknowledged his Polish nationality.

It is clear, however, that Elholm's participation in the Confederacy of Bar cannot be considered in itself as conclusive evidence of his Polish origin. But, in Czenstochowa County, Poland, there is a town called Olsztyn, renowned for the de-

9) Draper's Collection, 9DD 50. 


\section{POLAND AND THE AMERICAN REVOLUTIONARY WAR}

fense of Kasper Karlinski against the Austrians, in 1587. According to Polish geographical auhorities, ${ }^{10)}$ the original name of this city was Holstein. This fact leads one to suppose that Elholm might have come from this Polish Olsztyn, which some Americans identified with the better known Danish province of Holstein.

The author's further researches, however, led him to believe that this theory of the Polish origin of Elholm was also wrong and that most probably, though connected with Poland by the ties of blood shed for her liberty, he was not a Pole by birth.

Concerning Elholm's stay in Poland and his participation in the Bar Confederacy, the author has referred the matter to several historians of Poland. Their efforts to discover some trace of him in Poland were of no avail.

One of them, Professor Dr. Ladislaus Konopczynski of the Jagiellonian University at Cracow, the best authority on the Confederacy of Bar, informed the author by letter March 8, 1931, as follows: "The name Elholm sounds more Swedish than German; I have not found it among the names of the sub-officers of Casimir Pulaski, but this does not yet prove anything. The Marshal of Lomza (i. e. Pulaski) had among his volunteers many deserters from the Prussian and Austrian armies."

As to the supposition of Prof. Konopczynski that Elholm could have been a Swede, the author wishes to add, that he found no such name in the Swenskt Biografiskt Lexikon ${ }^{11)}$ nor in any other Swedish biographical dictionaries to which he had access. On the contrary, Mr. Hauch-Fausboell of Copenhagen is of the opinion that "the name Elholm could be Norvegian and the fact that Major Elholm was referred to as a Dane could be attributed to the circumstances that Norway up to the beginning of the nineteenth century belonged to Denmark." 12)

Prompted by the opinions of these two eminent scholars and by the sound of Elholm's name, which suggested that their supposition might be true, the author turned his researches to Sweden and Norway.

Hon. John Ball Osborne, American Consul General at Stockholm, Sweden, wrote him on January 29, 1932:

"With regard to the name Elholm I must say that the combination of 'El' and 'holm' does not sound Swedish and that a record of Swedish family names at the City Library of Stockholm does not include his name. The latter half of the name, however, is decidedly Swedish. It is taken from the Swedish word 'holme' meaning an island. Many Swedish family names in common use contain this ending.... The first half of the name in question, i. e. 'El' does not mean anything in the Swedish language.

10) Slownik Geograficzny Królestwa Polskiego, vol. I, p. p. 512-513.

11) Oerebro, $1850-60$, four volumes, and the more recent edition in Stockholm, 1906, two volumes.

12) The letter of Consul General N. Winship of Copenhagen to the author, June $3,1931$. 


\section{MAJOR ELHOLM}

"A search was also made at the City Library of historical and other records, suggested by the librarians, but no reference could be found of any Major Elholm. The Swedish War Department's Archives, where inquiries have also been made, had no record of any Swedish officer by the name of Elholm."

The results of the inquiry of Consul General Osborne seem to exclude the possibility of the Swedish origin of Elholm, especially in the light of the outcome of the author's inquiries in Norway.

Hon. Thomas H. Bevan, American Consul General at Oslo, Norway, at the request of the author, asked Mr. H. Blom Svendsen, the Chief Archivist of the Norwegian Government, for his opinion as to the chances of the theory of Norwegian origin of Elholm being true. Mr. Svendsen replied that "he made an examination of the material available in the State Archive in Oslo, but without results." In the meantime, however, he has learned that "several persons by the name of Elholm are living in Bergen" and he referred further investigation to the State Archive in Bergen. ${ }^{13)}$

At the request of Consul General Bevan of Oslo, Hon. E. Talbot Smith, American Consul at Bergen, Norway, undertook to do the task. His letter to the author of February 2, 1932, is as follows:

"The American Consul General at Oslo has forwarded to this office a copy of your letter addressed to him dated December 15,1931 , in which you state that you are working on a historical work concerning the American Revolution and are trying to disentagle the question of nationality of a very eminent Revolutionary soldier, Major Caesar Augustus George Elholm. The Consul General requests that an investigation be made at the Statsarkivet, Bergen....

"One of this office's staff has made such investigation at the Statsarkivet, and I therefore took the liberty of requesting him to search the records for any possible trace of Major Caesar Augustus George Elholm. As you probably know, the names of farms and the family names were generally identical in the eighteenth century in Norway. The only farm by the name of Elholm is in the Tysnes church parish, and the records of this parish from 1723 are at Bergen. They were searched carefully from year to year from 1723 until 1761. These records show that one Abraham Hansen Elholm who died in 1752 was married twice, first to Anna Nilsdatter and then with Helga Johansdatter. He had six children whose names and years of birth are as follows:

"Anne Abramsdatter, born 1728, single.

"Niels Abramsoen, married, oldest son, living at Elholm.

"Hans Abramsoen, born 1731, soldier.

13) The letter of Consul General Thomas H. Bevan of Oslo to the author, Jan. 23, 1932. 


\section{POLAND AND THE AMERICAN REVOLUTIONARY WAR}

“Abraham Abramsoen, born 1733.

"Mons Abramsoen, born 1750.

"Anne Abramsdatter, born 1747.

"It is barely possible that the third child of this marriage, Hans Abramsoen, born 1731, changed his name, for this was a common practice in those days. In the church records he is listed as a soldier and seems to have been the only one of this profession in the family. The possibility of his changing his name is actually not as ridiculous as it sounds at first, for it was a common practice for Norwegians going to foreign lands to change their names. The name Caesar Augustus George Elholm does not appear anywhere in the records, and it is very evident that the names Caesar, Augustus, and George are not Norwegian. This leads me to the supposition that they were assumed."

The results of the research of Hon. E. Talbot Smith seem to be the solution of the riddle of the nationality of Major Caesar Augustus George, or Augustus Christian George Elholm of the American Revolutionary Army, - and this is the more probable as the date of the birth of Hans Abramsoen Elholm in the Norvegian records corresponds more or less with his age. The belief that the names which Elholm used in America were only assumed, is strengthened by the existence of two sets of them.

It is now possible to reconstruct briefly the biography of Major Elholm before his coming to America. Born in Norway and wishing to follow the career of a soldier, he left his country early under assumed Christian names. The Prussian army was then the most perfect military machine in the world. The Prussian King gladly accepted foreigners as his soldiers; he even stole them from neighboring countries. It is, therefore, highly possible that Elholm received his first military schooling as a Prussian soldier. But he was a man of high ideals who could not long remain deaf to the summons of patriots in other parts of the world. When in 1768 the Poles formed the Confederacy of Bar to defend the independence and liberty of their country, he came to Poland and joined the movement. This last fact is beyond doubt, as it is mentioned in the letter of the member of Tipton's party, cited above. Elholm's participation in the Confederacy of Bar is a proof that, though probably not a Pole by birth, he was a Pole by choice, and that he offered his knightly ardor to Poland and her cause, just as a few years later he crossed the ocean to support the same ideals in the New World. It is possible that after the downfall of the Polish Confederacy he lived in Holstein, and that American historians mistook mentions of this fact for proofs of his Danish nationality.

It is not known when Elholm appeared in America, but Heitman records that he was commissioned Lieutenant of the cavalry of Pulaski Legion in April 1778, ${ }^{14}$ ) consequently he came here

14) Historical Register, p. 214. 


\section{MAJOR ELHOLM}

early in the Revolutionary War and was among the first officers of that famous corps. According to Williams, he received a Captain's commission under Pulaski. 15)

Our knowledge of Elholm's doings in America begins to be more exact since the ill-fated siege of Savannah. $\mathrm{He}$ is said to have taken part in "one of the most extraordinary captures the annals of warfare ever recorded" when he, together with Colonel John White of the Fourth Georgia Battalion and three or five other soldiers, captured at night by a ruse a British detachment on the Ogeechee River, commanded by Captain French and consisting of one hundred and eleven soldiers and forty sailors, besides five vessels, four of them fully armed, and much small arms. 16) Elholm and his companions "built many watch-fires around the camp of the British, placing them in such a position and at such intervals, as to induce Capt. French and his soldiers to believe that they were absolutely surrounded by a large force." To strengthen this belief, the daredevils made as much noise as possible. The ruse was completely successful. After the surrender of the British, the Americans collected the neighborhood militia who conducted the prisoners to the nearest American post at Sunbury. "Light Horse Harry" Lee vouches for the truth of this episode which, he says, might be considered a fable were it not confirmed by many participants of the Revolutionary War and denied by none. ${ }^{17)}$

After the heroic death of Pulaski Elholm remained with the Legion till May of 1780, and shared its later fate. He probably took part in the skirmish at Monk's Corner, April 18, 1780, in which the Legion suffered heavily, but resigned before its "sad remnants" were incorporated into the corps of Armand. According to Heitman, he served as Captain of South Carolina troops from February, 1781, to June, 1783. White and Williams report that he was commissioned in the dragoons of Col. Horry and "behaved with great galantry in the operations against the British in South Carolina." His experience in the guerilla warfare in Poland under such a leader as Pulaski was now of great benefit to the American cause.

One more interesting episode is recorded of his services in South Carolina. It pertains to his duel with Lt. Col. John McIntosh, already mentioned above.

The cause of the duel was said to be Elholm's "acting oppressively towards some of the inhabitants" of South Carolina. What was the "oppressive act" we do not know, but it might have been a trifling matter. It was nothing serious, anyhow, as there

15) Samuel Cole Williams, History of the Lost State of Franklin, Johnson City, Tenn., p. 301.

16) Geo. White, Historical Collections of Georgia, N. Y. 1854, p. p.

17) Henry Lee, Memoirs of the War in the Southern Department of the U.S., vol. I, p. 114. 


\section{POLAND AND THE AMERICAN REVOLUTIONARY WAR}

is no mention of any disciplinary action against Elholm. But McIntosh considered himself authorized to remonstrate with him. A quarrel ensued and both determined to fight it out with swords.

"The hostile parties," narrates White, "met under a large oak. At the word 'ready,' they drew, and advancing with sharp and glittering swords, commenced the battle in good earnest. In a little time the right arm of Capt. Elholm was nearly severed from his body, and fell powerless by his side. There was but a momentary pause, for he was a proud, fearless soldier, expert with his weapon, and naturally left-handed. His sword was dexterously transferred to his left hand, which he used with great effect; and the blows came so awkwardly, that they were not easily parried by his right-handed antagonist. Both were in a few moments disabled in such a manner, that the friends present felt it proper to interfere, and end the bloody conflict. They carried to their graves the scars and deeply furrowed cheeks, as evidence of a once terrible struggle." 18)

The duel with McIntosh was only a passing cloud on the horizon of Elholm's life. He is said to be always jolly, always singing and full of jokes, which made him popular with his comrades at arms. One of his friends was John Sevier, the hero of the battle of King's Mountain. Their friendship had a large influence upon the later life of Elholm.

After the Revolution Elholm's attention became occupied with the events in the western part of North Carolina. The hardy pioneers of the Watauga and Holston valleys dissatisfied with the State government which, they thought, neglected their interests, and, still more, with the cession of their country, without their consent, to the federal goverment to fund the Revolutionary debts, declared their independence in 1784, and established a separate State which they called Frankland, the land of the free. This name was later changed to Franklin, in honor of Benjamin Franklin.

The leader of the movement was John Sevier, now elected Governor of Franklin. Elholm's friendship for him led the Major to go to Franklin; nor was this the only cause; he was just as much influenced by the hope of being again of help to those who wished to be free.

It is impossible to ascertain when Elholm appeared in Franklin. But if the Franks chose him as their ambassador to Georgia in 1786 , it is evident that he must have been well known to them at that time, consequently that he lived among them for some time before that date. His character is the strongest evidence that he joined Sevier and his Franks soon after the declaration of their independence.

The prospects for the new State were not very promising. North Carolina considered them as rebels, but, in order not to

18) Geo. White, Historical Collections of Georgia, p. p. 547-8. 


\section{MAJOR ELHOLM}

make the matter worse, recalled the act for ceding the territory to the Congress of the United States and tried to mitigate the inhabitants by a conciliatory attitude. This caused a division among the inhabitants; some of them with John Sevier at their head remained faithful to the new Commonwealth; others, whose leader was John Tipton, began to gravitate toward submission to the mother State. Besides these internal troubles, the young Republic was constantly endangered by Indians who, encouraged by their dissensions, frequently attacked the homes of the whites.

Williams says that "Major Elholm entered the service of the State as Adjutant General and continued faithful to the cause to the end of her existence. He organized and drilled the militia, having had the advantages of experience in foreign service and a technical skill beyond that of any of the border soldiery." 19) According to Wagener, "he organized the militia with great skill and became very popular on account of his temper, especially among young people who, encouraged by his leadership, looked upon arms as a toy and upon the campaign as a recreation." 20 )

$\mathrm{He}$ evidently also performed the duties of the treasurer of Franklin, though with less success. ${ }^{21)}$

Wishing to safeguard the new State against the imminent attack of the Creeks, Sevier sent Elholm to Georgia, then also endangered by them, with a proposition of an alliance and an expedition against the neighboring Indians to break their power for all time. They also hoped that Georgia would play the role of a mediator between Franklin and North Carolina and would influence the latter to acknowledge the independence of the Franks.

"Bearing with him the strongest evidences of the Governor's confidence," 22) Elholm arrived at Augusta in September of 1786. Having presented his propositions he succeeded in securing an ambassador of Georgia to accompany him on his return. The preliminaries satisfactory to both sides were agreed upon. When Elholm came again to Augusta in the beginning of 1787, he was received with great honors by Governor Matthews and the House of Assembly, which voted him a resolution of thanks and a reward of fifty pounds.

"Major Elholm", says Ramsey, "had become, not less by his address than by his enthusiasm, a favorite of Georgia. The Executive Council received him as a man of distinction, and invited him to a seat with them, while the subject of his mission was under consideration. There and elsewhere, he took every opportunity to descant, in his fervid manner, and in the most

19) Williams, History of the Lost State of Franklin, p. 108.

20) J. A. Wagener, "Frankland und Franklyn", Der Deutsche Pionier, vol. II, p. 368 .

21) Williams, p. p. 216-218.

22) J. G. M. Ramsey, The Annals of Tennessee, p. 382. 


\section{POLAND AND THE AMERICAN REVOLUTIONARY WAR}

glowing terms, upon the excellence and beauty of the western country from which he came, and dwelt at length upon the prowess of the western people and their devotion to liberty and independence, and succeeded in creating an interest and enthusiasm in their behalf." 23 )

Upon the request of the Georgia legislature Elholm prepared a plan of a common expedition against the Creeks, and this was accepted in November, 1787. Honored by a letter of thanks from Governor Matthews of Georgia, he returned to Franklin, where the news of the treaty was received with joy by Governor Sevier and the people. In his circular to the militia of Franklin, of November 28, 1787, Sevier informed the inhabitants of the treaty and thanked publicly "our trusty and worthy Commissioner, Major Elholm," for his accomplishment. The legislature of Franklin, dividing the country into new districts, gave to the southern one the name of Elholm District. This name, however, disappeared with the downfall of Franklin.

Elholm was afterwards elected one of the three commissioners who were to procure the recognition of Franklin by the Congress of the United States, but the mission came to naught.

Meanwhile the position of the State of Franklin became worse and worse. Sevier hoped that the projected expedition against the Indians would occupy the minds of the Franks and mitigate their dissensions. But Congress appointed commissioners to make peace with the Indians, and Georgia suspended her preparations for war. Thus the alliance with her brought no practical results to the Franks. In the meantime the authority of Sevier grew weaker and weaker. North Carolina was firm in her denial of the recognition of Franklin and allured the western settlers to return to her authority by offering them amnesty and annulment of unpaid taxes. This caused many who still followed Sevier to desert him and to go over to the party of Tipton. In some of the counties there began to exist a twofold authority: that of Franklin and that of North Carolina, both rivaling with each other. The inhabitants of other counties ceased to recognize the authority of Sevier. In those trying days Elholm remained loyal to him to the end. He tried, it is said, to induce his friend to undertake "Cromwell's policy" against Tipton's party. "Had his advice been heeded," says Williams "Franklin might have had a different fate." 24) But Sevier preferred not to use compulsion.

Early in 1788 the North Carolina authorities undertook strong measures against Sevier. He was declared a traitor and his estate was seized. Having returned from an expedition against the Indians, he besieged John Tipton in his house for several days. The action against the belaguered was directed by Elholm.

23) Ib., p. 386 .

24) Williams, p. p. $301-3$. 


\section{MAJOR ELHOLM}

But though he could easily overpower his enemies, especially at the beginning of the siege, Sevier, not wishing to be a fratricide, retreated with his small army and thus the new State came to an end after four years of existence.

Major Elholm settled afterwards in Augusta, Ga. Governor Edward Telfair nominated him Adjutant General of Georgia during his administration 1790-1793. Disagreeing with his successor, Gov. Matthews, Elholm was court-martialed and dismissed. He spent his last days in Augusta practicing law and died there, November 23, 1799. If the author's supposition as to his origin were true, he was sixty eight years of age at his death. To his last days he remained a sincere friend of John Sevier, and when the latter was Governor of Tennessee he visited him rejoicing in the prosperity of the new State built on the ruins of old Franklin. ${ }^{25)}$

Williams justly characterizes him as "a man of heroic mold, who had in days of stress and need given valuable service to the State and Nation." He was, indeed, a soldier of fortune, so common in those days, but a soldier of the highest type. He did not sell his toil and blood for money or for the sake of his profession. Neither in Poland, nor in America could he expect anything except to give his service to the ideals of Liberty. $\mathrm{He}$ should be justly remembered with gratitude by both countries.

25) Tennessee Historical Mag., V, 244, 245, 252. 

VIII.

POLES AMONG THE LOYALISTS 
The American Revolutionary War was not only a war between the revolting Colonies and their mother country, but also a civil war among the inhabitants of the Colonies themselves.

In the opinion of John Adams, the second President of the United States, nearly one third of the population of the Colonies remained loyal to the Crown during the struggle, and Thomas McKean, the Chief Justice of Pennsylvania and President of Congress, considered the proportion of Tories even larger than that.

The fratricidal character of the Revolutionary War is emphasized by the fact that about 20,000 Americans fought on the British side, in the regular army and in the militias.

Personal opinions and feelings were not always a deciding factor whether one shall be a Whig or a Tory. The causes of Loyalism were various. Some of the Tories considered their loyalty to the Crown a question of conscience; others believed the Revolutionary movement doomed from the start; still others became Loyalists in the eyes of their countrymen because they strove to restore peace; there were also many others who were only the victims of circumstances over which they had no control.

It is easier to understand their motives now, a hundred and fifty years after the Revolution. History long ago reversed the contemporary verdict and, in most cases, pronounced them not guilty of any national crime.

There were among the Tories some of the foremost contemporary Americans. There were also, without question, men who honestly believed their sympathies to be on the right side, and who were acting in the best intentions.

If the war for the independence of America was one of the most sublime movements in the world's history, it is difficult, indeed, to deny that Loyalism, in many, if not in most cases, was also born of noble motives.

The Polish immigration in the United States, like that of other national groups, was also represented in the ranks of the Loyalists. This fact does not diminish their merits in any way. In the clash of two opposite ideas, there necessarily must have been a difference of opinions. Only treason or traffic in human blood could disgrace them. But no Polish landgrave, nor a prince ever sold his men for cannonfodder. The Poles who became Loyalists kept their faith to the last. One of them died a hero's death, another paid for his loyalty with exile, others again with their estates. 


\section{POLAND AND THE AMERICAN REVOLUTIONARY WAR}

\section{BLASZKOWICZ, CHARLES ${ }^{1)}$}

About half a century ago, there appeared in the Magazine of American History ${ }^{2)}$ the following question:

"Charles Blaskowitz. - What is known of this individual, whose name appears as the author of several Revolutionary maps? Was he an engineer-officer, and in what service, British or Hessian? Some of his works display much skill and accuracy."

The question remained unanswered. There was no one among the readers of the magazine who could give any information about the man.

The author tried to solve the riddle for several years, and though the information he gathered is meager, he is in position to give a few facts which will throw some light on that person.

Charles Blaskowitz, or rather Blaszkowicz, was according to all appearances, a Polish noble. His name appears in the documents as Blaskowitz, sometimes Blascowitz, or Blaszkowitz. All these forms are a very slight variation of the Polish noble name Blaszkowicz and were, evidently, dictated with regard to pronounciation. This is especially true of the ending of the name; the popular Polish ending "wicz" would be read "whiz" by an Englishman, while it should sound like "vitch" or "witz."

Polish heraldry books mention a family of that name, ${ }^{3)}$ so it may be safely assumed that Charles Blaszkowicz was a Pole.

It is impossible to learn when he came to America, but he was already here a few years before the Revolutionary War as an engineer in the service of the British government. His official title was "deputy surveyor for North America."

This fact is shown from the existence of two of his maps in the British Museum in London. One of the maps is dated 1772, - and it is important for his biography because of this date; the other bears no date.

The map of 1772 is entitled: Coloured Plan of the Coast from Pleasant River to the Penobscot Bay, surveyed in 1772 by Charles Blaskowitz and James Grant, deputies to Surveyor-General Samuel Holland. ${ }^{4)}$

The undated map bears the title: Coloured Plan of the Sea coast from Cape Elizabeth on the west side of Easco Bay to St. John River in the Bay of Fundy, etc., Surveyed by Ensigns George Sproule, James Grant, Charles Blaskowitz and Thomas Wright, deputy surveyors. ${ }^{5)}$

1) Pronounced Blashcovitch.

2) Vol. VIII, p. 437.

3) Zernicki-Szeliga, Der Polnische Adel, Hamburg, 1910.

4) British Museum, King's Charts, CXX, 21.

5) Ib., CXX, 18. 


\section{POLES AMONG THE LOYALISTS}

The fact that the name of Grant appears on both maps may be taken as an indication that they were made in a relatively short period of time.

If Blaszkowicz made a map of Penobscot Bay, Maine, in 1772, he must have come to America at least shortly before that time. His excellent education as cartographer suggests that he was educated, and probably born, in Europe. He was not older than about twenty five in 1772, as he was still living in 1814 and even took an active part in the second British-American War.

The next of his maps which the author was able to trace bears the date June 1774. Its original is, or at least was in 1882, in the possession of the Russell family of Plymouth, Mass., and bears the following inscription in Blaszkowicz's handwriting:

Plan of Plimouth, including Bays, Harbors and Islands etc., by Charles Blaskowitz, one of Deputy-Surveyors for North America and by him presented to Edward Winslow, June 1774. ${ }^{6}$ )

The existence of these maps shows that the British government sent Blaszkowicz to America to make surveys of the North American coast at the time when the Revolutionary War was imminent, but still unsuspected. This, in turn shows that he was not an engineer in the Hessian service, as the author of the query supposed.

Blaszkowicz's skill as cartographer is generally acknowledged. "In 1876, Mr. Henry Mitchell, of the United States Coast Survey, who was then stationed at Plymouth, made a partial sketch of the original Blaskowitz map, still in an excellent state of preservation, for the sake of making a scientific record of its early information upon Plymouth Harbor, its channels, soundings, etc., as they existed before the American Revolution. Mr. Mitchell, in his official report, said: 'In its topographical features the original plotting made by Blaskowitz from his survey of Plymouth is remarkable for accuracy and beauty'; 'the details were admirably executed upon the original with pen and brush'; the map was 'generally faithful'." ?)

This map by Blaszkowicz is considered "a most valuable contribution to the historical geography of Plymouth." 8 )

The above maps are probably all that has been preserved of Blaszkowicz's work before the Revolution, though, without question, he made more.

When the war broke out, Blaszkowicz remained loyal to the British flag. In face of the division of the American society, what could be expected of a foreigner in the service of the Crown? Nearly all the colonial officers kept their faith with the

6) Herbert B. Adams, "Plymouth Rock Restored," Mag. of Am. Hist., VIII, p. 797.

7) Ib., VIII, p. 798. The reproduction of the Blaszkowicz's map of Plymouth Bay may be found in the Magazine of American History, vol. VIII, p. 799 .

8) Ib., VIII, 798. 


\section{POLAND AND THE AMERICAN REVOLUTIONARY WAR}

mother government. If this was true even of those who were Americans by birth, it excuses entirely Blaszkowicz for not having betrayed those to whom he took the oath of loyalty.

During the war he advanced to the rank of Captain of the British army and evidently performed the duties of his profession, as may be seen from another of his maps, that of the Narragansett Bay, published at London in 1777. The title of this map is: A Topographical Chart of the Bay of Narragansett in New-England, taken by Charles Blaskowitz, and dedicated to Lord Percy, Lt. Gen. of his majesty's forces, showing the several works and batteries, raised by the Americans, with the banks, shoals and rocks. 9)

This is the only known map made by Blaszkowicz during the Revolution, but most probably he served in America during the whole war.

Gen. Hugh Percy, the future Duke of Northumberland, commanded against the Americans in 1775-76, and took part in the battle of Lexington and the reduction of Fort Washington. The dedication of the above map shows that Capt. Blaszkowicz served on his staff in the beginning of the war, and evidently later was attached to the army which occupied Newport, R. I.

The next traces of him are found in Canada in 1800, which suggests that he shared the fate of the Loyalists and was transferred there after the war. He remained in the British army as Captain on the staff of Quartermaster General and in 1802 retired with half pay. ${ }^{10)}$

A quarter of a century after the Revolutionary War a new British-American War called him back to duty. $\mathrm{He}$ is mentioned in the documents of 1812 and 1813 as Captain of the Royal Newfoundland Fencibles, but it seems, that he did little active service. He was furloughed soon because of bad health and old age, and his name does not appear again in the later documents of the war. He probably died soon after.

\section{GRABOWSKI-}

The author was unable to learn his first name. Contemporary sources call him only by his family name with the addition of the title Count. There are several different families of this name in Poland. The title of Grabowski and his position on the staff of Gen. Henry Clinton, as his aid-de-camp, suggest that he was a relative of Major General Grabowski of the Polish army, the first husband of the morganatic wife of the King Stanislaus Augustus. It is also possible that he was a relative of Count Michael Grabowski, Captain of the Legion of the Duke de Lauzun.

9) New England Hist. and Geneal. Register, XXIV, p. 80. This map is reproduced in Cullum's Historical Sketch of the Fortification Defences of Narragansett Bay, Wash., 1884, p. 10.

10) Public Archives of Canada, Ottawa, Search Ref. No. 9146. 


\section{POLES AMONG THE LOYALISTS}

Count Grabowski probably did not belong to the regular British army, as he is not mentioned in W. C. Ford's British Officers serving in the American Revolution, 11) nor in any other similar register. There is also no mention of him in the Revolutionary documents of the War Office nor in those of the Colonial Office in London, as far as the author could ascertain.

The absence of Grabowski's name from the British official documents may be taken as a proof that he served with the army of Sir Henry Clinton as a volunteer.

Moore, indeed, says of him that he was "a Polish noble who entered the British service as a volunteer." 12)

He was still a young man, fond of adventures and eager to distinguish himself.

Grabowski probably joined Clinton at New York, offering him his sword and bravery. The exact date of his arrival is not known; at any event, he was there in the Fall of 1777.

At that time Kosciuszko was helping Gates to hold back Burgoyne who was trying to reach New York from Canada in order to separate New England from the rest of the Colonies. His progress having been arrested at Saratoga, he found himself in a critical position. Gen. Clinton left New York to bring him relief. But this action was too late. The army of Clinton was only able to capture the forts Montgomery, Clinton and Constitution in the Hudson valley when the news came of Burgoyne's surrender. After destroying the forts and burning the town of Kingston, N. Y., Clinton returned to New York.

Grabowski accompanied Sir Henry on this expedition, not to return alive. He fell on the field of glory at Fort Clinton, October 5, 1777.

Six years later, in 1783 , shortly after the war, another young Pole went the way of Clinton's expedition. He was not a soldier, but a poet, who, filled with enthusiasm over the American victory, visited the still fresh battlefields of the Revolution.

Near Fort Clinton his attention was called to a grave. $\mathrm{He}$ was told that this was the place of the eternal rest of the ashes of his brave countryman who died during the attack on the fort.

This traveler was Cajetan Wengierski. In order "to plant a branch of laurel upon the grave of his friend and to snatch his name out of oblivion," he left a description of his death in his memoir. According to Wengierski, Grabowski was hit by a bullet at the moment he was about to answer a question of Gen. Clinton, during the attack. He adds that Grabowski "gained the friendship and respect of his generals." ${ }^{13)}$

11) Brooklyn, 1897. p. 509 , note.

12) A. Moore, Diary of the American Revolution, N. Y., 1858, vol. I,

13) M. Haiman, Polacy $w$ Walce o Niepodleglość Ameryki, Chicago, 1931 , p. $202-3$. 


\section{POLAND AND THE AMERICAN REVOLUTIONARY WAR}

In this last statement the poet seems to be right. Gen. Clinton evidently held him in high esteem as in his official report of the attack, though not mentioning Grabowski by name, he said that "his loss was not very considerable, excepting in some respectable officers who were killed in the attack." 14)

But Wengierski probably was wrong when he called Grabowski a British Captain, nor does he seem to be well informed of the particulars of his death.

The British historian of the Revolutionary War, Stedman, gives a different version of that event:

"Count Grabowsky, a Polish nobleman, who had crossed the Atlantic to make a campaign as a volunteer with the British, likewise fell on this occasion. But his death was attended with a little circumstance which ought to be mentioned in honour to his memory. He had advanced to the storm in company with Lord Rawdon amongst the grenadiers, but was separated from him amongst the felled trees, which forced every man to find a path for himself. Arriving at the foot of the work he fell, after having received three balls; when giving his sword to a grenadier, he conjured him, with his expiring voice, to deliver it to Lord Rawdon, and to assure his lordship that he died in a manner becoming one who had shared the dangers of such gallant troops." 15)

The version of Stedman deserves more credit than that of Wengierski. Stedman himself served in the Revolutionary War; Wengierski recorded what he heard from a tenth or a hundreth mouth.

As Wengierski calls Count Grabowski his "friend," it is possible that he knew him at Warsaw. And as the poet was one of the King's chamberlains and lived in the court circles it gives additional weight to the supposition that Grabowski was a relative of General Grabowski of the Polish army.

It was not given to Wengierski to immortalize the name of his friend. His memoir was forgotten for over a century. Stedman was more lucky, as some historians repeated after him the narrative of the heroic death of the young Count which must command the respect of even a foe.

Benson J. Lossing saw the grave of the brave Pole sixty years later. "A pile of stones still marks the burial place of the Count," says he in his Pictorial Field Book of the Revolution.16) It is not known to the author whether the grave still exists.

14) H. B. Carrington, Battles of the American Revolution, p. 359.

15) Charles Stedman, The History of the Origin, Progress and Termination of the American War, London, 1794, vol. I, p. 362.

16) B. J. Lossing, Pictorial Field Book of the Revolution, N. Y., 1852. vol. II, p. 168 . 


\section{POLES AMONG THE LOYALISTS}

\section{ZABRISKIES.}

John Zabriskie, grandson of Albrecht Zaborowski, the founder of this well known colonial family of Polish origin, filled the office of justice in New Jersey. In 1774, he was elected a member of the Bergen County Committee of Correspondence. ${ }^{17)}$ These committees, consisting of the most prominent citizens of the locality, were organized for common action against the acts of the British Parliament obnoxious to the colonists. His part in it shows that he sympathized with the patriots to some extent. After the outbreak of hostilities he was undecided as to which side he should take. He was a Colonel of militia of Bergen County and resigned his commission not sooner than June 16, 1776, choosing loyalty to the Crown, as did nearly all other colonial officers. For this he paid later with the loss of his estate. It was confiscated by the Revolutionary authorities and by an act of December, 1783, given to Major General Baron de Steuben.

"New Jersey gave to Steuben the life lease to a forfeited estate of John Zabriskie, lying in the County of Bergen, township of New Barbadoes, at the New Bridge, and in the immediate neighborhood of New York; but Steuben, when informed that Zabriskie, in consequence of that confiscation, was left without means, did not accept the gift, and interceded in behalf of Zabriskie." 18 )

The documents mention also Albert Zabriskie, a Loyalist, whose estate at Hackensack, consisting of 143 and a half acres, was confiscated June 10, 1779, because he enlisted in the British army in December, 1776.

17) L. Sabine, American Loyalists, vol. II, p. 731.

18) Friedrich Kapp, Life of Steuben, N. Y., 1859, p. 597. 

IX.

A POLISH POET'S TRAVEL IN AMERICA IN 1783 

1.

Wengierski succumbs to the fashionable French epidemic of travel in America. - His fatiguing journey across the Atlantic. - He is a welcome guest in Philadelphia. - His visit in Washington's headquarters.

The reports of America's struggle for freedom were reaching the ears of the French for several years, stirring deep sympathies for the Colonies and, at the same time, preparing the way for the bloody deluge of the Great Revolution which was soon to follow.

Thomas Cajetan Wengierski, ${ }^{1)}$ who at that time lived in France as a voluntary exile, could not remain indifferent to the currents penetrating his new surrounding. He was the same giddy-head as he had been in Warsaw; he liked, as of old, "young women and old wine," but, though a spoiled child of his time, he was not wanting in noble impulses.

The poet was born in Poland in 1755. Among contemporary Polish writers only few could rival him in power of expression and brilliancy of satire, none in spitefulness. With his pen he scourged even those who held highest places in society, entertaining whole Warsaw at their expense. He was the terror of all who had anything on their consciences. A malicious poem against the Russian Empress, Catherine II, brought him into the prison where he remained for over a year.

Strongly afflicted by this punishment, he left his country in 1779 , not to return there any more.

During his gay life on the streets of Paris, the news from America kept reaching his ears day after day. America was the theme of conversations in the salons of aristocracy and in the houses of commoners. She was idealized as a country of tranquil and pastoral life, as a land of peaceful farmers, who under the influence of the watchwords of Freedom were transformed into heroes; as a real vision of the new world, happier and nobler than the old one. Young French nobles competed for the honor of drawing their swords for the freedom of the Western Hemisphere.

The popularity of America in Europe was greatly enhanced by the Letters of an American Farmer by Hector St. John de Crevecoeur, a French-American. The first edition of these letters appeared in England in $\mathbf{1 7 8 2}$ and was sold out at once. They were republished many times and translated into many languages.

In his Letters De Crevecoeur described America in a simple, though colorful style. His idealized sketches of American life

1) Pronounced Wenghersky. 


\section{POLAND AND THE AMERICAN REVOLUTIONARY WAR}

fascinated European readers. Wengierski himself wrote of them that "they are an enchanting picture of the happy life of the inhabitants of English America, especially of the farmers of Pennsylvania, sketched with a simplicity worthy of better times which I have not yet found anywhere else." 2)

The young poet was unhappy in France. Frivolous as he was, he felt the pangs of exile. He had no true friend. The debts contracted by an improvident life vexed him. When the American war ended and everybody in France who could afford it hurried to visit the dreamed of land, he also was carried away by the wave of sympathy for the new country. He decided to go "to see Northern America" and to get personally acquainted with the then most popular person in France - George Washington.

He had nothing to lose, anyhow, and the projected voyage afforded a new and unusual pastime for the poet, tired already of Parisian life.

He accordingly sailed from France on May 16, 1783, by way of the West Indies. A certain Julia whose charms the poet did homage to at that time was to have been his companion, but the beloved one having lost interest in the long and inconvenient voyage disappointed him. Wengierski sailed alone, that is, with his servant, Richard.

It is possible that already in France he had some knowledge of the English language. To amuse himself during the voyage and to better his language facilities he took with him the Letters of an American Farmer.

Wengierski planned his travel as only a visit of not longer than a few months duration. He left a description of his ad. ventures and impressions in letters and in a diary. The originals written in French have been lost, but there exist contemporary manuscript copies of them in the Jagiellonian Library at Cracow and in the library of Count Chreptowicz at Szczorsy, in Poland. They appeared in print only recently for the first and only time in a Polish weekly Przewodnik Naukowy $i$ Literacki. ${ }^{3)}$ They are divided into two parts:-1) Letters to a Friend (Julia) in Paris written in the form of diary during the voyage to Martinique in 1783 and 2) The Travels to Northern America of the Polish Count K. W.; a diary of the voyage on the Hudson River to Saratoga and thence to Lakes George and Champlain, and the return to Boston by way of Connecticut." The following is, with some omissions, a translation of Wengierski's papers based on this edition.

The second part is of especial value to us for two reasons. It is the oldest known Polish diary concerning America and the more interesting as the author occupies quite an eminent

\footnotetext{
2) Wengierski to Julia, June 8, 1783, Przewodnik Naukowy $i$ Literacki, Lwow, 1908.

3) The MSS were edited by Dr. Stanislaus Kossowski. 


\section{A POLISH POET'S TRAVEL IN AMERICA IN 1783}

place in Polish literature. Secondly, his memoirs contain accounts concerning some of the most distinguished leaders of the Revolution, and a description of historical occurrences and of the country at that memorable moment when the United States emerged from the war as an independent power.

The letters to Julia written at sea are less interesting from a historical point of view. Their chief value is biographical. A few paragraphs acquaint us with the mode of life of the poet, his disposition and views before entering the American domain. Otherwise they are full of tender expressions for his beloved. They reflect the tiresome monotony of the old sea voyages when three miles per hour was considered swift sailing; when companions, because of the dimensions of the ships, were not numerous and soon became tedious, and the cuisine was unpalatable for lack of fresh provisions. Wengierski suffered from sea sickness and "from a thousand other ailments" nearly without intermission and rarely ventured out of his hammock.

"Our life is devoid of all interest," - wrote he to Julia, May 23, 1783. "After ten or eleven hours of frequently interrupted sleep, we breakfast, then dress. But this is an occupation which has not yet taken much of my time. I did not yet take off my robe. My beard is of extraordinary length. Complying with the wishes of my companions, I decided yesterday to part with it, but at the first trial Richard nearly cut off half of my lip and the large plaster put on the wound increased the number of my graces without diminishing the number of the hair of my beard. At twelve we dine. Nothing can compare with the soiled condition of our table-cloth which is changed only once a week. The rolling of the ship causes the sauces to pour out abundantly on the cloth; this variety of colors which makes the cloth look like the palette of a painter, strengthens the abomination for the food which the quality and moide of preparation naturally excite in one. But all this begins to interest me just today, as this is the first time I appeared at table. We sup at six thirty; then we give one leap from the dining room to our beds. I forgot to tell you that they say prayer here three times daily."

The only diversity in this monotonous life on the vessel advancing with snail-like velocity was a stray bird, sometimes a meeting with another vessel, or a storm; the poet occupied himself with reading the Letters of an American Farmer and a few modern French books, and by writing to his Julia. $\mathrm{He}$ assured her several times that he made great progress in acquiring the English language. Once his tired nerves had some diversion in the "rebellion" of his Richard whom he "was obliged to put in irons."

On Tuesday, June 24, at sunrise, 40 days from France, the poet saw at last the coast of Martinique, a French colony. The next day he landed at St. Pierre and with one of his companions, 


\section{POLAND AND THE AMERICAN REVOLUTIONARY WAR}

Mr. de Fontenill, went on a stroll through the city. He visited the French Governor and saw a show in a miserable local theatre.

He also made excursions by boat and on horseback into the interior of the island and for the first time had occasion to observe the slavery of negroes which evoked his sympathy for them.

On July 1 , he moved to Port Royal, Jamaica, where he stayed at the house of a French officer and planter who was the father of one of his companions in voyage.

On Monday, July 14, he sailed along the coast of Porto Rico to Santo Domingo which he reached on July 22 . The voyage again was fatiguing and not without sea sickness. He landed sick and downcast, full of tormenting uncertainty as to the fidelity of Julia. But at this point his correspondence with her is cut short. We do not know anything about the poet till his stay in Philadelphia where he must have been in the first days of September, 1783, if not earlier. It is not known how he reached this city.

His sojourn in Philadelphia fell at the time when the Revolutionary War still nominally existed, although the land operations had already ceased. The ultimate peace treaty acknowledging the independence of the United States was near to being

signed. The preliminaries were signed some time before. The British garrison still occupied New York, but this was the last visible sign of the once English reign over the thirteen colonies. The existence of the United States was nearly assured externally, at least. Her main difficulties were now internal. The people discussed everywhere how to strengthen the Union and the authority of Congress, how to organize the federal government, how to subdue regional jealousy, how to lift the country from the deluge of the war debts.

Wengierski entered at once into the whirlpool of these discussions and in the homes of Philadelphia's citizens had the opportunity to make the first direct acquaintance not only with public affairs, but also with eminent personages representing various schools of American political thought. "I discussed often"-he says - "the most knotty problems with foremost persons in America for several hours; I could hardly say a few words in English, but one word was sometimes enough to express my thought."

One of his new friends was John Dickinson, then President of the Council of Pennsylvania, to whom he wrote from Philadelphia, September 7, 1783, concerning the most famous of his political writings:

"I have been at several bookshops to buy a copy of The Letters of a Farmer in Pennsylvania, but it is the fate of good works that they are sold out soon after printing. They teach and enlighten the people while mediocre works enjoy repose and 
shelter themselves before the greedy hands of men. Whatever value your work has, it would be most valuable for me if I could get it from its author. Excuse the boldness with which I ask for it. I would like this gift to be the same as "tessera" among the ancient peoples and that it would be henceforth a pledge of the hospitality, with which you have received me, and of friendship, which I sincerely wish to conclude with you.

"If then you will allow that a citizen of a dying Republic writes to you sometimes to support the rising Republic, I shall consider myself most happy. But the profit of this correspondence would be entirely mine because when you will tell me of the virtues and progress of the new world, I shall be able to inform you only about the downfall and vices of the old one."

Philadelphia entertained Wengierski "hospitably, kindly and politely." He pays her compliments reciprocally in his diary:"In no country have I found such ease, such sincerity, with which the foremost personages act here; their virtues, the precious inheritance of the old Quaker customs, distinguish Pennsylvania from her neighbors." No wonder that when the day of his de. parture arrived, in the beginning of October, he left the city with regret.

Several Frenchmen who like Wengierski wanted to see America accompanied him in his further travel. Their way lead through a country which was the scene of a long war. Wengierski recalls in his narrative many details of the struggle. Some of them are generally known, so only these extracts are cited here which have historical value as his own observations or pertain to some less known facts.

"We left the city at three o'clock in the morning," he writes under date of October 8th. - "We took our places in a large carriage which is called here the 'flying machine.' It was the first time I found myself in a public diligence; it was not too comfortable, especially as the road was very stony and the shocks horrible. It would be proper to tell a few jokes to our companions to save ourselves from the tediousness of the journey, but I had no time to do this; and, besides, these men did nothing to encourage our attempts. Mr. Vernon (a companion of Wengierski), who is an uncommon wit, accosted them, but without any result. As to me, I had not the slighest inclination to laugh, for I sat on a very hard seat shaking with the horrible jumping of the carriage.

"The morning was a little chilly, but we left the blinds of the carriage open. We saw the daybreak at Bristol where we stopped for breakfast. It is a small town, eight miles from Philadelphia; the driver changed horses there. After a brief rest and a very poor breakfast, we drove to Trenton Ferry where the Delaware flows; this river is about three shots wide. In general the banks of the Delaware are pleasant, but a little too flat and monotonous. Nearby lies Trenton. It was in this city that the 


\section{POLAND AND THE AMERICAN REVOLUTIONARY WAR}

Hessian brigade was captured December 25, 1776, by Washington, thanks to his bravery and to the carelessness of Col. Rahl.

"The battle of Trenton was the first considerable victory of the Americans over the British. The Hessian prisoners were triumphantly brought to Philadelphia where the people of the vicinity gathered to see those unhappy Germans bought so dearly and coming from so far. Their courage and cruelty magnified the terror of their name, and the peaceful people of Pennsylvania observed them with the same curiosity with which the Romans saw for the first time the terrible lions brought by Sulla from Africa.

"Between Trenton and Princeton there is nothing worth one's attention except the large tree around which the giant rocks form a cave called Rocky-House; on the top of these rocks, fires were kindled which served as signal to assemble for the militia of New Jersey."

In the evening of the same day Wengierski reached Princeton, N. J., where the Continental Congress held its session. At the inn he met Gen. Nathanael Greene, the companion in arms of Gen. Thaddeus Kosciuszko. Wengierski had made his acquaintance already in Philadelphia. He says of him in his diary :

"He is the only American general besides Washington who has won the praises of both, friend and foe. The British, even the most prejudiced among them, always spoke to me about him with respect. Engaged in business and in the practice of the peaceful religion of Quakers in his early years, he girded the sword at the first sign of danger to his country. Called to the difficult and tedious office of Quartermaster in the beginning of the war, he was made General. He was sent to the South, where he showed great abilities and became the main factor of the Revolution in those provinces. Like Marcellus of yore, he was never defeated on the field; he forced the victorious Cornwallis to leave South Carolina and compelled Mylord Rawdon to return to Charleston. His modesty equals his merits, and the mildness of his character and a very careful education, which the majority of the American generals lack, made him a very agreeable man."

From Princeton Wengierski made an excursion with Gen. Greene to Rocky Hill, N. J., where Washington made his last Revolutionary headquarters. Free from the pressing war business the General led a more leisurely life and could without the loss of his precious time receive the young Pole who crossed the ocean to see him. A letter of recommendation from Lafayette opened to him the modest quarters of Washington.

Wengierski thus describes this unusual meeting:

"I decided to go to see General Washington at Rocky Hill where he lives in a country house waiting for the discharge of 


\section{A POLISH POET'S TRAVEL IN AMERICA IN 1783}

the army and for the installation of a constitutional government. Since Gen. Greene intended to visit Gen. Washington also, we set out together. The weather was terrible, but the hope of seeing the great man encouraged me to suffer it patiently. Marquis de Lafayette gave me a letter to his friend, and I knew that with such a recommendation I should not be received inhospitably; and besides, in such circumstances one gathers all his powers and rouses all his senses to action in order not to show himself a pigmy before such a great man.

"I will not give you a portrait of our hero as he is quite well known because of his deeds; I will only add that he is the only man whose voice always carries weight whether in the legislatures of the various states or in Congress.

"Others, though they have their merits, are not so much respected and have influence only in their states.

"All the portraits of Washington which I saw in Europe scarcely bear any resemblance to him. He is one of the most handsome men I ever met; of noble stature, his face is that of a warrior, his manners amiable. The kindness with which he treated me from the beginning to the end, pleased me very much, and after two hours one would think that our acquaintance was of long standing. Though I had a great desire to hear from him about the causes of the last war and about the public affairs of the country, he avoided such a turn in the conversation. I guarded myself from uttering an impetuous praise of him and waited for an occasion to insert skilfully a few compliments. But the conversation became so general and passed to such far away themes that it was impossible for me to return to my original intention without offering him constraint.

"We started to talk about my travels and he gave me letters of recommendation to Gen. Knox at West Point and to Gen. Schuyler at Albany; I accepted them saying that my expedition to the North is only accidental and that the main purpose of my journey was to see and get acquainted with the chief author of American liberty. He invited me also to spend a few days on his estate at Mount Vernon, in Virginia. I left him with regret all the more intense since I did not expect to see him again. I returned to Princeton very tired, but fully satisfied with the day thus spent."

Did Wengierski see Washington again at Princeton, as might be judged from the copy of a letter in his papers erroneously dated October 18, 1784? Wengierski was not in America at that time. Circumstances point out that the letter was written at Princeton before October 10, 1783. It is addressed to Washington and reads as follows:

"I hope that time will permit Your Excellency to come here tomorrow and I am happy at the thought that I shall see you again. 


\section{POLAND AND THE AMERICAN REVOLUTIONARY WAR}

"I traveled several thousands of miles to see and to get acquainted with creators of American liberty not only that I might boast of seeing them but also that I might learn from them how to preserve the most precious laws for a nation.

"I am a citizen of an unhappy country, formerly free and powerful, now weak and misgoverned. How happy would I be if I could imagine, when talking with you or listening diligently to your words, that by imitating you I will be useful to my country some day. Such dreams are excusable. Though circumstances do not allow me to stay with you longer, I do not doubt that I shall see you some day in your retreat in Virginia and I am sure that seeing Washington in his country seat will be as interesting to me as if I had seen Fabricius or Cincinnatus."

The diary of Wengierski does not mention a second meeting with Washington. The General came to Princeton about October 10. ${ }^{4)}$ The poet hearing of his intended arrival hoped perhaps to see him again and wrote the letter cited above. But it is apparent that they never met again.

In the morning October 9th, Wengierski visited Charles Thompson, Secretary of Congress, the learned and honest immigrant from Ireland. He breakfasted with him. Says he of Thompson:- "He is a man who because of his simplicity of manners may take a middle place between a patriarch and farmer and may be easily taken for the one or the other. I had ample time to judge the merits of his breakfast, but not enough to pass upon the virtues of the man; I think they must be notable as he has always acted as Secretary of Congress even in the most trying times."

On the same day Wengierski started his journey to Brunswick, N. J., and in the evening reached Elizabeth, N. J.

2.

Wengierski meets the exiled Tories.-His sojourn among the Engish at New York. - The voyage up the Hudson. - At the grave of a countryman. - West Point and Poughkeepsie. - Livingston and Hamilton. - Albany.

Our traveler was now nearing New York. The following pages of his diary give an interesting picture of the future American metropolis, and her surroundings at the beginning of the independent United States.

"October 9th. - The country along the banks of the Raritan is cultivated to a great extent; one can often find rich farmers there; but it could hold a many times greater population and could feed six times as many people. If anybody in Europe thinks that America is overpopulated, he is in error. Even

4) "Itinerary of Gen. Washington from June 15, 1775, to Dec. 23, 1783," Penna. Magazine, XV. 


\section{A POLISH POET'S TRAVEL IN AMERICA IN 1783}

the most exaggerated estimates could not show more than three million people. To populate fairly well the enormous territory which the United States gained by the last treaty, thirty million people would not be too many. It is true that most settlements are not older than a century; every inhabitant who has cleared a piece of land has a good house, several heads of cattle, a pair of horses at least, and about fifty sheep; he has an orchard planted with apple-trees and corn. The cultivated lands lie among the forests which rise amphitheatrically and look as if checkered by the irregular clearings; this gives to the eye the variety which entertains and does not tire. On arriving at Elizabethtown, the view widens infinitely; we can see Amboy, the sea, Sandy-Hook, Newark and the highlands.

"We intended to go to New York that same evening, but could not find a boat and consequently had to spend the night at Elizabethtown. I slept in a room where eight days ago a Frenchman had been robbed so thoroughly that he was left in his only shirt. Since the war ended, the discharged soldiers and various vagabonds started many very audacious thefts, entering the homes and burglarizing them. During our travel we read many announcements of rewards for the capture of a gang of thieves who burglarized some shops and stole much goods.

"October 10th. - At ten o'clock in the morning, a small wagon brought our baggage to the bank, a little less than two miles from Elizabethtown. The sea and wind favored us, so we soon passed Staten and Long Islands and in about two hours landed in New York.

"It is difficult to imagine a more beautiful view than that which one sees on nearing this city. It rises majestically and amphitheatrically, and even its ruins add to its charm; the character of the land is different on both sides; the highest possible culture and wild nature in all its magnificence pass in view alternately. Staten and Long Islands form a contrast satisfactory to the eye; on the other side of New Jersey tower formidable rocks and trees, stately in their age and height, and worthy of their primitive inhabitants.

"The bay was full of English men-of-war and the flag of Great Britain still fluttered from the fort. At the Narrows we saw many buildings for various purposes; they were full of unhappy Royalists who were obliged to leave New York. Several days ago the storm destroyed a ship sailing to Fundy Bay; from among the two hundred exiles who were aboard only fourteen survived and even these were none too happy. There is no greater misfortune" - writes the poet who himself was also an exile "than to be obliged to leave your own country, to separate yourself from parents, friends, daily habits, to leave the house which you have built yourself, to abandon the soil which you cultivated, to leave the government which you were satisfied with, and to 


\section{POLAND AND THE AMERICAN REVOLUTIONARY WAR}

go to an unknown country, to till the ungrateful soil and to become an alien."

Wengierski describes his stay at New York under date of October 11: "We met with great difficulties trying to find a lodging after our arrival; all public inns were occupied by the Tories fleeing before the persecution of their countrymen. Great grief reigned among the British army as well as among the inhabitants of New York, and the most beautiful buildings in ruins, the monuments of the King and of Lord Chatham overthrown and shattered, houses and shops empty and deserted completed the gloominess of the picture. Gen. C......n, ${ }^{5)}$ the Commander in Chief, put many difficulties in the way of allowing foreigners to come into the city; he refused many French officers permission to visit it. I did not know that these precautions, needless in time of peace, pertained to foreigners of all kind; so when I was watching a military parade, I was informed that General H.... ${ }^{6)}$ expressed his surprise that I had entered the city without his permission. I in turn expressed my own astonishment at his surprise and replied that I had not the honor of bearing arms against England; and, moreover, that I was a citizen of a country which never had been and probably never will be at war with His Majesty, the English King; a country which did not even proclaim the neutrality of her army, and, therefore, I would be unjustly afflicted by such a prohibition; the above deductions evidently made an impression on his suspicious mind as I did not hear him say anything more. Gen. Clarke ${ }^{7}$ whom I learned to know rewarded me for this haste with a kind reception. He is a man of exceptional worth and a very respected officer; he served in America since the beginning of the war and took an active part in nearly all campaigns."

On October 12th, Wengierski made an excursion to Long Island where he was a guest at a dinner with General Clarke.

"Long Island is about one hundred and twenty miles long and ten miles wide and was formed partly by the sea and partly by the river. The northern part is fertile and cultivated, and produces choice lumber. The soil of the southern part is barren and stony. The island was the scene of the first war activities and of the success of Chevalier Howe; - a success which he did not know how to utilize for he allowed the American army to escape, though he could easily have destroyed it. The passage between Long Island and the Island of New York is nearly a

5) Sir Guy Carleton, (1724-1808), the last Commander-in-Chief of the British forces in the Colonies.

6) Probably the British General Henry Hamilton, (-1796), one of the most active promoters of Indian raids upon the frontier settlements of America.

7) The British General Alured Clarke, (1745-1832), former Commander of Savannah, where he won, by his courtesy, the good will of the inhabitants. 


\section{A POLISH POET'S TRAVEL IN AMERICA IN 1783}

mile wide, and one could not imagine how a victorious army could have allowed a handful of fleeing men to cross a passage so wide unmolested. The fortifications of the island were of practically no significance, and now there are no ditches besides those which the farmer ploughed out between the furrows."

The next two days he spent preparing himself for a journey to West Point. Above all, he had to buy his own provisions, and occasionally complains of their high cost. "To my great surprise the good inkeeper demanded of us three pounds sterling for a large lamb."

"October 15th. We went to the boat which was already full of passengers; they were all, as they say in America, gentlemen, that is, merchants, butchers, laborers, on their way to Albany to clear themselves of the suspicion of Torism. They drank all day in order to forget their situation. If to be a bore were a crime, they all certainly deserved to be hanged. The greatest annoyance to me was that the wind was adverse and the ebb was too strong. It seemed that I should be obliged to stay a few days in this company.

"The Hudson is, without doubt, one of the most beautiful and extraordinary rivers in the world. It flows straightly from north to south and often forces its way through a chain of mountains which it divides perpendicularly; it is more like a perfect canal which a human hand led through the rocks. It would be impossible to describe the astonishing impressions, picturesque situations and charming banks of this river. The most talented painter, a poet of a most exuberant imagination could only give a feeble notion of it. Nature did everything to this land, and art as yet spoiled nothing in it; everything there breathes majesty, a greatness which astonishes man, and a variety which charms him. Because of insufficient tide and steady adverse winds we cast anchor six miles from the city, opposite the beautiful house of Mr. Apthorp, ${ }^{8)}$ one of our traveling companions who was accused of being a Tory and had to go to Albany to clear himself. His house, built well and with great taste, has a spacious garden, perfectly planned, with a giant rock in the middle of the yard; one can see from thence both rivers, the East River and the Hudson, which water both sides of the island.

"October 16th. At 11 in the morning the wind blew from the south and we set out on our way. The weather was beautiful, nearly as warm as in Summer. We had plenty of leisure to observe the charming banks of New Jersey in all their beauty. They are covered with impenetrable forests which look as if they grow on rocks; the rocks rising perpendicularly over the water or scattered at random present a picture of immense disorder. In one hour we made as much progress as we made

8) C. W. Apthorp, a rich Loyalist. 
all day yesterday with so much difficulty and passed near Forts Lee and Knyphausen. The latter was called Fort Washington before it was captured by Gen. Howe. It is still guarded by British troops whose lines extend to King's Bridge, or rather to a small natural port Spuyten-Duyvil, in the northern part of Manhattan. The American pickets are stationed on the opposite bank. We saw two hostile sentries holding a peaceful conversation.

"From Spuyten-Duyvil to the Croton River we sailed along the estate of Philipse's; ${ }^{9)}$ it extends nearly twenty four miles along the bank and reaches from four to five miles in depth. This land is of high value and best cultivated in the State of New York; it is now to be taken from the proprietor, confiscated and sold. The old Colonel pays for his loyalty to His Majesty, the British King, with a loss of an estate worth nearly a million pounds sterling yearly and is left with his wife and children to the discretion of the British parliament. ${ }^{10)}$ I saw him at New York, broken down with age and sickness; he was preparing to leave his country and follow the rest of the British army.

"The river widens here and forms a large lake which the Dutch called Tappan Sea; the name was preserved till now. Before entering a place which is called Rockland, one crosses the boundary of New Jersey; beyond that point both banks belong to New York. Tappan Sea is nearly five miles long. The river then resumes its usual width. To the east we see a land cultivated very carefully; the houses, settlements, and mills fill the valley and adorn the highlands, while the western part preserves constantly its wild beauty. The mountains which present an array of cliffs and dense forests seem to indicate a very monotonous view, but the skilled hand of nature scattered this deformed material with such an art and placed it in situations so well chosen that it forms an unbroken chain which enchants the eye. On top of one of the highest peaks we saw a large pile of dried wood together with various combustible materials and we were informed that such precautions extend to Albany and served as signals in case of a move by the British army or fleet.

"Our attention was called also to a very lofty peak on which there is a lake, where very good fish can be caught. A mile beyond this point the land begins to grow level on both sides and the river widens again and forms a kind of a bay which has preserved its old Dutch name Haverstraw-Bay. But the river does not long enjoy this enlargement; two capes, Stony Point and Verplancks Point, close it in and form a kind of narrows. These two important

9) Frederick Philipse, (1746-1785), owner of Philipse Manor Hall.

10) Though one of the richest Tories, Philipse's income did not reach that sum. A. C. Flick gives the value of his confiscated estate at $\$ 777,000$, (Loyalism in New York during the Am. Rev., N. Y., 1901). 


\section{A POLISH POET'S TRAVEL IN AMERICA IN 1783}

points were captured by Henry Clinton in 1777, but two years later General Wayne attacked Col. Johnson at Stony Point and took him prisoner with all his men;11) the timely action of Col. Webster of the 33rd Regiment saved Verplancks.

"I forgot to mention that on this side of Stony Point we saw the small house of Mr. Smith, ${ }^{12)}$ where the inquisitive Andre and Gen. Arnold held their meetings; I was told that Arnold was not the only one in his family who was cheated and that love strew with flowers the way which brought the Major to his degrading death.

"If this be true, then I do not know of any more unhappy end than the one which this young officer had found; but let us hope that some day an impartial historian combining this dolorous war with the fate of this unhappy man will do justice to his virtue and bravery and will console his tormented soul.

"From Stony Point the mountains rise higher and higher, and the bed of the river becomes narrower and narrower; the river is deeper here, but not swifter; it flows majestically and is in no hurry to leave its beautiful banks.

"It is difficult to imagine surroundings more romantic than these. The pen of Ariosto could not invent a like miracle. One breathes here a mild melancholy; and deep silence which reigns here invites one to meditation and opens a broad vista to the imagination.

"It was after sunset when we passed between the rocks. The pale moonlight illumined the mountain tops which bowed, as if vaults over our heads; looking at my reflection in the clear and tranquil water I remained in ecstasy for a few moments, but I awoke soon when the ship trembled slightly as she started to move forward."

The poet was now near the battlefields of Clinton's expedition in 1777. Near Fort Clinton his attention was attracted by the grave of his friend from Warsaw, who died a hero's death as an officer of the British army. It was the young Count Grabowski, aid-de-camp to Gen. Clinton, who fell during the attack on Fort Clinton, October 5, 1777.

"The pen of a great historian" - writes Wengierski, "does not condescend to write about the death of a subaltern officer, and a small hill covering the remains of a brave soldier does not attract the attention of the traveler; but a countryman should be allowed to plant a branch of laurel upon the grave of his friend and to snatch his name out of oblivion.

"Chevalier Clinton called him to show him some work which he considered practicable and asked his opinion about it. Gra-

11) July 15,1779 .

12) Joshua Hett Smith, (1736-1818), brother of the Tory Chief Justice William Smith, connected with the treason of Benedict Arnold. 


\section{POLAND AND THE AMERICAN REVOLUTIONARY WAR}

bowski was about to answer him when suddenly a bullet struck him in the breast killing him instantly. ${ }^{13)}$

"We passed quickly the Forts Clinton and Montgomery which were captured by the British after a stubborn defense. The young Count Grabowski was killed there in the attack; he was a Captain of the English army and gained the friendship and respect of his generals.

"The wind which gained entrance into these narrows began to blow with greater force and carried us off sooner than I wanted. It was eight o'clock when we disembarked at West Point where we had to stop. Gen. Knox to whom we handed the letters from Gen. Washington was so good that he invited us to his house, and as I spent a very bad night on the boat, I felt happy finding myself in a tolerably good bed.

"October 17th. This morning I saw from the windows of my room two regiments of infantry; they looked quite well in arms. Those who are accustomed to the appearance of the European soldiers would not be satisfied with the manner in which American soldiers go through their exercises. They would find in them neither that martial step, nor that admirable coordination which particularly distinguishes the German army. Yet these men and the militia so badly drilled forced two whole armies, excellently disciplined and presenting a formidable array, to surrender.

"Aifter breakfast we visited the fortress where arms, ammunition and supplies of the United States are stored. This is the American 'pandemonium.' We saw the explosive bombs which Burgoyne brought with him and which the Americans acquired by the treaty of Saratoga. Each of them is engraved in golden letters where and when it was captured; they are kept in good order, and Gen. Knox assured us that they numbered more than four hundred. The fort in which all the ammunition is stored is called Clinton, formerly it was Fort Arnold.

"Opposite West Point is Constitution Island. A chain stretched from one bank to the other completely closes the passage. ${ }^{14)}$

"The highest of the forts is called Fort Putman; when Arnold planned his treason, he ordered a large breach to be made there leading the American officers to believe that he did it to enlarge the interior of the fort. All these fortifications are in poor condition, but nature herself contributed abundantly to their defense; the towering rocks everywhere make them nearly impregnable, and even a smallest handful of men skilfully managed would be able to stop a large army here. The rest of the American army is camping on a small plain at the foot of the

13) This differs in the particulars of the death of Grabowski as given by Stedman. See chapter "Poles among the Loyalists."

14) The chain was drawn by Gen. Kosciuszko. 


\section{A POLISH POET'S TRAVEL IN AMERICA IN 1783}

mountains. We were assured that it numbers nearly four thousand men, but I hardly believe it to be that large.

"At noon we left our General; he is an ardent Republican, formerly a bookseller in Boston; he was one of the first of the 'rebels' and one of the most enthusiastic supporters of the Revolution. He lent us his boat which conveyed us to Poughkeepsie in less than five hours. After we left the narrows formed by West Point and Constitution Island, we saw another small island called Polopells. Though both banks are rather well cultivated, their aspect is less pleasing; one does not meet here those charming pictures which distinguish the vicinity of West Point. We saw several iron foundries, but the British army destroyed the settlements. The surrounding woods are mostly oaks, pines and cedars and greatly facilitate the mining of iron ore. This mining is easy, anyhow, as the mineral is found on the surface of the earth. I read during the day the English translation of the Travels of Peter Kalm; ${ }^{15}$ ) it amuses me especially by its exaggerated exactness; the author omits no story which he heard from the people. I think he was a better botanist than historian, for everything which he describes of the herbs and trees of this land is instructive.

"We were much dissatisfied when, after arriving at Poughkeepsie, ${ }^{16)}$ we learned that Gov. Clinton was away; we were especially recommended to him and I hoped that he would give me accurate information concerning this State and some events of the Revolution. His mother-in-law whom we found at home received us very hospitably; she is 74 years of age, a Presbyterian; her hospitality and kindness were extraordinary.

"October 18th. We expected to leave this morning and to reach the Livingston Manor by land, but it rained all day; and since the carriages used here are not covered, we preferred to stay and await better weather. I used my leisure time in arranging the material for my diary and in supplying you with a few of the particulars still wanting to complete the picture of American customs and manners. It may be taken as an axiom that a traveler dining each day with a different host will eat for a month the same kind of dishes prepared in the same manner. The table of a general, a governor, a tenant or an innkeeper is similar in all respects: mutton, beef, pork; pork, beef, mutton; beef, mutton, pork - these are the fundamental articles of food at each meal. It consists mostly of two large pieces of meat served with potatoes and with various salads. I saw only one exception to this rule, and this was in the home

15) A Swede who traveled in the United States in 1748.

16) Poughkeepsie was then the seat of the legislature and Governor George Clinton, (1739-1812), who held this office, by successive elections, eighteen years and was Vice-President of the United States from 1805 to 1812. 


\section{POLAND AND THE AMERICAN REVOLUTIONARY WAR}

of the richest citizen of Philadelphia at a dinner for twenty persons.

"They are accustomed here to satisfy the appetite, not to irritate it; to be sure, those two large pieces are sufficient for anyone to eat his fill.

"The poorest tenant in America eats more meat in one week than many a European farmer does, even in the countries where he fares best, in a whole year. Rum mixed with water is the most popular drink, but you can find Portwine or Madeira everywhere. Here they make excellent beer from molasses and some kind of fir-tree, called spruce-beer. All inventions which make life more comfortable and pleasant, all luxuries are unknown to them, except in the cities; and even there these are very rare. But those few pieces of furniture which serve their daily use are kept with cleanliness and elegance unseen in our countries.

"October 19-th. We had a shower this morning; a very strong northern gale did not stop the rain. We remained the whole day with our good old lady and with $\mathrm{Mr}$. Benson ${ }^{17)}$ with whom I discussed the tax system of this province. I also looked over a large book of laws of this State and saw that here, as everywhere, their sphere of application is very limited and their conception evidently contingent.

"As to the tax system it may be said it is very imperfect and even arbitrary, and subject to many formalities.

"October 20th. On rising from my bed this morning I saw the tops of the Catskill mountains covered with snow; the weather was rather frosty, but clear, and the wind quieted completely; we decided to set out and bid farewell to our hosts. I was sorry that we could not travel by water, but the wind was adverse and, moreover, we could not find a boat. The only way to travel in this land when one has not his own horses is to hire a small wagon which makes nearly forty miles a day; these carriages are very inconvenient, especially when the roads are bad as they are now, but it is possible to suffer this fatigue, and, I think, it makes itself less felt if one travels far, than if one does so on horseback. You can cross the whole of America in these wagons and reach the most remote points; and though the inns are not situated most conveniently, there is always something to eat - good bread, fresh butter, potatoes, which are much more tasteful than the European, and often good mutton; this is a very good meal after a whole morning of shaking and fasting. One often finds inns with beds, but it is safer to have one's own mattress and cover. Fresh straw is more comfortable than an old bed, which is frequently full of vermin and never clean enough to assure the traveler a restful night.

17) Egbert Benson, (1746-1833), the first Attorney General of the State of New York. 


\section{A. POLISH POET'S TRAVEL IN AMERICA IN 1783}

"We left Poughkeepsie at ten o'clock and for some time followed the bank of our beautiful river. The ground was a little elevated and overlooking the banks of the river; after viewing sufficiently the fertile fields which the river waters, our eyes rested on the endless chains of bluish mountains. Their tops covered with snow presented to us a picture of severe winter, while we in the valley enjoyed a moderate temperature. Often the turning of the road or a rock projecting from the water covered the view before us, but soon our attention was attracted to another surprise and the eyes, sensible to casual impression, forgot quickly what they beheld a moment before.

"We soon saw the ruins of Kingston which was burnt by Gen. Vaughan who was sent with Henry Clinton to help Burgoyne. Those two Generals said that they came here in vain because he whom they had to join, no longer needed their help. They burned all the houses here. Several inhabitants perished in the flames. Instead of going to Albany, which was then without a garrison and where the Americans had their stores and about two thousand sick in the hospital, they returned whence they came and a most terrible devastation was the only result of their expedition.

"We lost sight of the river two miles from Esopus and passed the forests of Rhinebeck Township; this region throughout its extension has nothing remarkable except that its inhabitants are mostly Germans or Dutchmen; they speak bad English and their accent is wholly foreign. We saw on our way as many churches as houses and observed that the inhabitants of this region are better devotees than farmers. In the main this country is badly cultivated and the forests are destroyed in such a manner that their absence will soon be painfully felt. When they want to clear an acre of land, they set fire to the trees which cover it; many trees still show incisions which they make to get resin used in making pitch and tar. All fences are made of timber and are built with imprudent waste; no wonder that we failed to see even one hundred large trees in a stretch of twelve miles.

"At about five in the afternoon, leaving Albany County, we turned on our way to see Chancellor Livingston; this excursion brought us again to the banks of the river. The Livingstons are one of the most prominent families in the State; the Chancellor of New York ${ }^{18}$ ) was Secretary of Foreign Affairs during the war. His house had been burnt by the British and only recently rebuilt; we were received very hospitably and spent the evening very agreeably; therefore, it required much courage to leave such a charming place the next morning. The house is situated very delightfully; the family occupying it is kind, and every traveler after a fatiguing and tedious voyage feels the charm of an agreeable society here more strongly. Our fear to meet impassable

18) Robert R. Livingston, (1747-1813), American statesman. 


\section{POLAND AND THE AMERICAN REVOLUTIONARY WAR}

roads was the only cause which prompted us to leave the place where we have been received so well; on leaving, we turned our eyes toward it several times and rewarded with sincere regret the hospitality showed to us.

"October 21st. The day was beautiful and sometimes the heat became nearly unbearable. Traveling is disagreeable here; the roads and bridges are in a bad condition and we moved slowly in mud; we had to ford several creeks. The aspect of the country gave us ample time to meditate over the tediousness of our journey. I was happy when the day was over; we spent the night near Kinderhook, 25 miles from Albany, in the inn of a Captain.

"October 22nd. My mattress was very useful to me last night; the innkeeper, though a Captain, had no beds for us and demanded such a price as if we had slept on feather beds instead of on the floor. We left him wishing that he might get a quicker promotion in the army and be more moderate in his prices.

"The roads were again bad and tedious this morning; we passed through a forest of fir-trees where we found several hunters lying in wait for squirrels. The Americans are wonderful marksmen and seldom miss their mark. Their columns aimed always at the British officers during the war and several persons assured me that Great Britain lost more officers in America during the last war than America had lost in all the parts of the world at any time.

"After making twenty miles through the woods, mostly on foot, we saw Albany from the top of a hill and soon found ourselves there, safe and sound.

"We live beyond the city with Mr. Hamilton, ${ }^{19)}$ brother-inlaw to Gen. Schuyler. His beautiful house stands on a hill overlooking a large portion of the country. We intend to stay here two days to get the needed information about our voyage. I hope that my diary will be more interesting henceforth; we are penetrating a country less known though famous because of important events.

"October 24th. We came this morning to the city to dine with Col. Lewis, ${ }^{20)}$ brother-in-law to Chancellor Livingston, and at the same time to visit the city. Col. Hamilton accompanied us on this excursion, and we had the pleasure of being entertained by his conversation; he is a young man of twenty seven years and certainly one of the most distinguished citizens of America.

"He was aid-de-camp to Gen. Washington for a long time and his chief defender; he lead the attack on the redoubt of Yorktown. ${ }^{21)}$ Later he exchanged his sword for the robe of a lawyer and is now engaged in his new occupation with as

\footnotetext{
19) Alexander Hamilton.

20) Morgan Lewis. (1754-1844), American jurist and soldier.

21) October 14, 1781.
} 


\section{A POLISH POET'S TRAVEL IN AMERICA IN 1783}

much zeal and success as he had shown skill and activity in his former career. His mind is universal, his judgment positive, and his education very careful. $\mathrm{He}$ is free of the prejudices of his own country, judges the events impartially, without passion for his opinion; he knows how to value his countrymen who were active in the Revolution.

"Albany has absolutely nothing deserving attention; only the large hospital built by the British during the war in Canada, may be interesting to the traveler; but the situation of the city is very beautiful and the river which serves to embellish it contributes also to facilitate trade with New York.

"After dinner we busied ourselves with the preparations for our journey. The people frighten us with insurmountable difficulties; they say that the bridges are destroyed, the roads impassable and the rivers swollen. But we have with us the two indispensable things: - great patience and curiosity, and the war cry of our small detachment is: 'Always forward'."

3.

Cohoes Falls. - The batilefield of Saratoga. - Gen. Schuyler. -A troublesome night.-Lakes George and Champlain.

"October 25th. We left Albany at noon, having only two small bundles as our whole baggage and a little sugar, tea and a few lemons as our whole stock of provisions. At first we followed the bank of the Hudson to a place called Schuyler-Farms where we turned to the left to see the great Cohoes Falls on the Mohawk. We had scarcely made three miles when we heard distinctly the roar of the falls. 'What is this noise'-asked Mr. Vernon. 'That is the echo of the falls,' I answered, and we forced our way ahead through the forest; with each step of our horses the noise increased until it became so great that we could not hear each other speak. From time to time we saw through the trees the river sweeping vehemently away the foam collected at the banks. The weather was fine and agreeable, but the spray caused by the violent commotion of the water falling from a considerable height warned us that we are near the place; the view of the falls was still obstructed by the wood, but the terrific noise itself made an impression on us. The impatience of our curiosity, the strong feeling of loneliness which surrounded us all this produced a chaos in my soul which I like to experience. At this point we left our horses and penetrated on foot into the wood, but it is impossible to describe my feelings when from the height of a hill I saw the gigantic cascade of water falling into the abyss; the river is 329 yards wide in this place and the height of the falls is 75 feet.

"The river gains in swiftness before the falls because of the declivity of the ground. The rocks at the brink of the falls form 


\section{POLAND AND THE AMERICAN REVOLUTIONARY WAR}

a series of dams which by checking the flow seem to add to the impetuosity and determination of the water to plunge headlong into the steaming surge. Add to this an astonishing charm of a rainbow which unites the most vivid colors to the dusk of a dark, dense fog, the terrible roar caused by the falling of a large mass of water from a great height and the curious effect of boiling water at the foot of the falls - and you will have a faint idea of the picture.

"We would have remained there perhaps till sunset in ecstasy over this most beautiful view entrancing us, were it not for our men who pressed by hunger and evidently not so sensible to beauty of this kind, reminded us that we had yet to make more than twelve miles before dinner, and that we are already very late. We returned to our horses two miles below, crossed the Mohawk, and rode along a highway to Saratoga. We dined in a place called the Half-Moon where the junction of the Mohawk and the Hudson forms something like a half-moon. I will not tell you of the bad roads which we encountered. The night overtook us as we were leaving the Half-Moon, and we forded several large creeks in darkness and without a leader, running a chance of drowning; at last a redeeming light showed us our inn. Our horses exerted their remaining strength at the sight of this good star and soon brought us to a house more comfortable than we could expect. A Captain of the militia was the owner of this inn. His family consisted of his wife, about thirty years of age, and of a beautiful daughter of fifteen or sixteen. A baby eight months old rested peacefully in the middle of a room where the whole family slept.

"On rising from my bed next morning I saw the grave of Sir Francis Clarke, adjutant to Gen. Burgoyne. A lonely firtree planted on the spot as it were by chance, is the only ornament of this sad place. Having been mortally wounded and taken prisoner at Stillwater, Sir Francis was placed in the house near our inn and died there.

"October 26th. What a terrible fate it is to die in a strange country, to breathe one's last in the house of an enemy, surrounded by unknown or indifferent faces. No sympathy, no sigh accompanies him to the grave and he has to believe with a sad certainty that all the services which they give him do not come from a tender heart. Let it be so! But I cannot overcome a strong emotion and drive away the thoughts of my present condition of traveling in a far off country hardly known in Europe. If the fatigue of the troublesome journey, the influence of a very changeable climate, the numerous adventures should break down my weak health, I should never see you again. My memory would be buried in the grave which would consume my body and would not cross the ocean to evoke a thought of me in the minds of my countrymen. I should die without the opportunity of putting in order and publishing the materials collected with such difficulty. May a 


\section{A POLISH POET'S TRAVEL IN AMERICA IN 1783}

good deity direct my journey and favor my return! May I not die, at least before I attain to fame.

"We turned to the road towards Stillwater and looked over the remnants of fortifications at Bemis' Heights erected by the Americans to check the progress of the British." 22$)$

After narrating the events connected with the battle of Saratoga, Wengierski thus describes the battlefield at Freeman's Farm, the place of one of the encounters which brought about the surrender of Burgoyne:

"Though I was not a witness of these events, I could not overcome a painful feeling at the sight of the spot, the saddest I have ever seen in my life. Imagine a hilly region covered with mournful fir-trees, which, having been half-burnt and stripped of branches, show only besmoked trunks; everywhere are traces of terrible devastation; birds of prey in vain seek nourishment looking at the bones still preserved by time; the howling of the winds strikes the ears with a shrill and chilling sound.

"Having explored the various positions of the British army, we went to Saratoga by the same way the British had come, through worst roads, but with greater safety than they; we soon saw the mansion of Gen. Schuyler. About one hundred American troops are in the barracks at Saratoga; this is the only force above West Point. All other forts and the Canadian border are deserted, and there is no living soul to defend them.

"A large part of Saratoga Township belongs to Gen. Schuyler; he built mills on Fishkill of peculiar construction, which bring him handsome profits. He is very rich and very active.

"After taking breakfast with Mr. Schuyler we again set out on our journey and having crossed the Hudson we came to Fort Edward. All houses and all settlements in this part of the country were either destroyed or burned during the passage of the British army, and we met only several huts which now shelter the inhabitants. With difficulty we recognized the site of the old Fort Edward; the road which we passed thence to Wingsfalls is memorable at every step because of deadly encounters which were fought here during the war of 1758. The cruelty of the Indians drenched this entire country with the blood of white people; but the barbaric events do not deserve mention.

"We traveled along the bank of the river without scarcely any rest and had occasion to see one of the most dangerous ferry crossings existing anywhere. The river is beset by rocks which form frequent and considerable waterfalls; but the raft with a crew of four or five men rushes with the greatest speed down from a height of twelve to fifteen feet, suffering no damage whatsoever. About sunset we reached the house of a Quaker named Wings who gave his name to the main cascade. This cascade is perhaps the most picturesque thing in the world, and the impres-

22) These fortifications were the work of Gen. Kosciuszko. 


\section{POLAND AND THE AMERICAN REVOLUTIONARY WAR}

sion which it makes is so manifold that it defies description and no brush is able to depict it. 'The King' divides the river into two branches; the eastern branch flows down a gentle declivity and falls without much agitation; but the western part breaking its waters at three very considerable steps forms three falls of different height and tumbles down into the precipice where it joins the first branch. Thus united the waters raging and climbing flow about fifty paces and, meeting an island on their way, embrace it. Surrounding the island and covering it with white foam, they form a strong contrast with the evergreen trees growing there.

"It was nearly six o'clock when we left the falls, and the good Quaker who led us there brought us back to our road; we went further through a wood. We passed a small lake called Bloody Pond, where Gen. Johnson defeated and captured Baron de Dieskau; old Hendrick, the famous Mohawk chieftain, died in this battle, which was so bloody that the waters of the lake remained red for a long time. ${ }^{23)}$

"Night surprised us in the wood and we could not find a place to sleep except a small cabin. After a day which tired us much, we had no chance to rest. There were no doors nor windows in the room and the winds were blowing from all sides. Notwithstanding these inconveniences we fell asleep, but were awakened during the night from the deepest sleep by piercing cries. We thought at first that Indians were attacking us, but it was the landlady who was in labor. The laughter evoked by this mistake, the cries of the newly-born, the moans of the mother and the curses of those who were not able to sleep because of it all, composed a scene worthy to be included in a comic romance.

"October 27th. There was no use in trying to go to sleep again so we took advantage of the time to find a boat for our passage. Everything was ready at about four o'clock, and we embarked without delay. The stars were still shining. The weather was calm, and the clear skies promised us a good journey. The rowers put into good humor by a bottle of rum readily shoved out into the lake. Without regret we lost sight of the cabin where we had spent the night and moved onward quickly. Deep silence surrounded us; the surface of the water was calm and smooth; the light of the stars which soon faded showed us our way, when suddenly we were enveloped by a darkness usually preceding the dawn of the day so that we could scarcely see the motion of oars though we heard their monotonous splash. Thus cut off by the darkness how many sad thoughts absorbed my mind! What a great distance I traversed mentally before the

23) The battle was fought between the provincial troops under Maj. Gen. Sir William Johnson, aided by a body of Indians under Hendrick, the Mohawk chieftain, and a body of French Canadians and Indians under Baron Dieskau, a French nobleman. 


\section{A POLISH POET'S TRAVEL IN AMERICA IN 1783}

boat had advanced twenty paces! I forgot that I was on the lake, in a frail boat, and my thoughts taking wing fled across seas and mountains dividing me from Europe and rested on the nature of my own follies; all this irritated my soul, contrasting strongly with the surrounding quiet; but slowly day began to break and the tormenting thoughts took leave of my distracted senses.

"The waters of Lake George are of inconceivable transparency, clearness and purity; at a depth of seven or eight feet one can see the bottom of yellow sand, strewn with stones and frolicking fishes. Mist, the unhealthy product of standing waters, never rises out of these pure waters. The lake clear as crystal is hemmed in by two chains of lofty mountains and immence rocks which form various and separated grottos worthy to serve as meeting places for mythical lovers. The tops of the mountains are covered with woods known only to bears, stags, moose and courageous hunters whose only weapon is a rifle, and sole companion a dog; they penetrate these woods, often spending there a fortnight, sleeping under the sky and eating raw meat. The lake is studded with innumerable islands, it is said that there are more than 300 of them. ${ }^{24)}$ These form narrows, zigzags, labyrinths and splendid basins, and the incessant variety makes the voyage very romantic and interesting. Many of these islands bear names commemorating various events distinguishing them, and not a few of them were the scenes of bloody encounters and terrible massacres. Diamond Island, now called Burgoyne's, was the place where the General had established military stores during his unhappy expedition. The Americans attacked it, but Count Aubrey defended it successfully. Goat Island is noted for the death of Lord Howe in 1758. We dined at an island called Fourteen Miles Island, amidst heaps of skeletons, the remnants of an American detachment commanded by Major Hopkins, and surprised and cut down by the Indians. The waters which would be worthy because of their clearness to bathe the living members of Venus or the pure body of Diana, served only to wash the bleached skulls of the dead wariors; the splendid grottoes which should welcome only happy lovers, serve as hiding-places for wild beasts; the echo which in such a charming place should resound only with the sighs of lovers or exclamations of happiness was condemned to repeat the warcries, the wild and barbaric shouts of the invaders, or the moans of the unhappy victims.

"The wind which started up suddenly from the north at about two o'clock retarded our voyage a little, and we did not land until after sunset. We were informed that we had to transport our baggage thence and go by foot to Ticonderoga, three miles from the landing. The pleasant day had a troublesome ending

24) In fact, about 220 . 


\section{POLAND AND THE AMERICAN REVOLUTIONARY WAR}

for us. We had to walk in a pitch-dark night, without a guide, through a barren and marshy country. Often we waded in the water up to our knees and every now and then fell into holes. At last, after two hours of fatiguing journey, we discovered a small barrack situated near the falls obstructing the passage from Lake George to a canal connecting it with Lake Champlain. With the greatest difficulty we obtained there a boat to cross the channel and at about eleven o'clock arrived at the foot of the old Fort Ticonderoga. The owner and rower of our boat was a Colonel of militia. Taking leave of him we showed him how flattered we were to have so high an officer transporting us, but he was not satisfied with kind words and demanded such an exorbitant fee for his services that I thought he wanted to make up on us for the arrears of his pay due him from Congress. The quarrel which ensued delayed still more the time of our rest, but we smoothed out the misunderstanding and spent the night drying our clothes and sipping tea.

"October 28th. While awaiting the boat for Crown Point we visited the ruins of the fort. It is totally destroyed now, and only a few chimneys stand out from among the ruins.

"Our boat was ready and took us to Crown Point. But what a difference between the waters of Lake George and those of Lake Champlain. The latter are muddy and emit unhealthy vapors which continually fill the atmosphere. The surrounding country is flat and very fertile. It was very populous and highly cultivated under French dominion, but two wars destroyed its settlements completely. Crown Point was formerly called Fort St. Frederic. Gen. Amherst occupied it in 1759, built there a new fort and spacious barracks. Here Burgoyne's army landed. The disturbances of the last war and the devastation committed here by the army deprived the inhabitants in this region of all the means of subsistence. It is, above all, a race of hardy people who spend their lives hunting, but do very little farming. We stayed at Crown Point only long enough to see the place. At night-time we returned in a very small boat guided by drunken men and exposed to being overturned at every stroke of the oars. Our boat several times struck the piles driven into the bottom of the channel to obstruct passage. It was already midnight when we found a landing place. We were faint from extreme fatigue. We did not sleep at all for three nights, and bad food did not add to our strength. We slept in a room occupied by twenty three persons, besides many hunters and a few Canadian travelers. The oarsmen promised to transport us in three hours, but it took them more than seven. We did not eat the whole day long, and for three days had not seen a morsel of bread; and the object for the seeing of which we under- 


\section{A POLISH POET'S TRAVEL IN AMERICA IN 1783}

took so great a fatigue was not worth our attention. Happily we came upon our Colonel Coffin ${ }^{25)}$ who was so good as to share his dinner with us."

4.

Wengierski's reflections upion American housing conditions, the size of the family, public safety and the unity of the nation.-Visit with the Indians.-A strange meeting.Journey through New England.-Classical farewell to Dickinson.

After making about three hundred miles from New York to the north Wengierski now started on his return trip. He traveled at first by his old route - through Lake George. October 29th he notes in his diary:- "We visited a few islands, among them one inhabited by a republic of beavers. I refer you to Father Raynal's ${ }^{26}$ ) that you may read about this industrial society, and I can assure you that it is infinitely more perfect in its system of building and living, in its methods of felling trees, sawing and roadbuilding than the people who inhabit these wild regions; the cabin of the inhabitant of this country differs as much from the house of a beaver as the latter differs from the most convenient apartment in Paris. You cannot imagine how carelessly the huts are built here. They have no doors, nor windows; the fissures which are unavoidable when one lays a $\log$ over another are left open; I am at a loss to understand how they can bear the severe winters of this climate in such houses. But the weather at that time was very agreeable."

Wengierski and his associates spent that night in the house of the same woman who by her moans interrupted their sleep a few days ago. Next day, October 30 , he visited Fort Edward. "The fort is now ruined and deserted," he notes. He reached Gen. Schuyler's mansion that evening and "felt so sick that he went to bed as quickly as possible."

The traveling fever did not allow him to take the needed rest. Though "totally sick" he set out for Schenectady the next morning, hoping to see Indians there.

$\mathrm{He}$ notes under date of October 31:- "We passed through Newton Township which is famous for the culture of an excellent kind of apples.

"The roads were so bad that our horses often sank into mud up to their breasts. We drove up to a farm to feed our horses, but did not find oats for them nor bread for us; we made four miles more and happened to meet an honest Swiss who offered us excellent cider and gave corn to our horses. He refused to take anything for his kindness and only asked that we remember him

25) Probably the man who charged them an exorbitant price for the ferry.

26) An eminent French priest and author. 


\section{POLAND AND THE AMERICAN REVOLUTIONARY WAR}

and tell his parents if we should ever stop in Switzerland that he lives happy and contented, that he has a nice and large family, and that he is bringing up seven children by the labor of his hands. It is hard for a European to believe what a large number of children one meets when traveling in America. To each farm there are six persons on an average. Everything which keeps the European peasant from enlarging his family encourages the American farmer to increase it. He knows that the more children he has the richer he will be, and he is justly convinced that the enormous piece of land which he cultivates only in part will, under the hands of his children, become a large cultivated field bringing in twenty times more profit.

"Leaving our Swiss we journeyed through an immense forest armed only with our canes. It is surprising that after eight years of war during which the soldiers were unpaid, there are no robbers; the roads are as safe as if guarded by gendarmes. The woods are full of hunters who, however, never attack an unarmed traveler. We traveled here by night and nearly always through woods, meeting no bad men and without fear.

"We walked along the fence of a farm near the Mohawk, and we spoke French. A man called to us in this language, and we learned that he was a Frenchman from Champagne, John Clere by name. He was made a prisoner in Canada, and after the exchange preferred rather to remain in this country than to return to France. He has a good farm here and another in Dutchess County. He says that he is doing very well and that he fought for the independence of America. I mentioned to him that this change of fortunes costs him his Champagne wine. 'But I have good cider,' - said he - 'I make punch sometimes, eat good mutton, excellent beef, and do what I like; my children will be richer than I because my land will be worth five or six times its present value in twenty or so years. All this' - he added-'is worth renouncing the sparkling wine.' I congratulated him on this opinion and thought that his reasoning was quite sensible.

"What attracted my attention most in the history of the American Revolution was that we had before us a nation of twenty nationalities differing not only in customs and language but also often contradictory in habits and religious convictions, uniting to fight the common foe by whose laws they had been governed. Thus the fear that nothing be done against their will exercises much influence upon the minds of independent men. There is, probably, no man less dependent in the world than the farmer in this land; removed from his neighbors, he reigns over his family, does not pay any taxes and has no obligations; he feels that he is equal to anybody in the world and does not even hear of government officials.

"We crossed the Mohawk and passed the beautiful village of Niskayuna. It is a Dutch colony; the houses are built wonder- 


\section{A POLISH POET'S TRAVEL IN AMERICA IN 1783}

fully, and everything bespeaks cleanliness and prosperity. We again entered the woods and came to Schenectady late that day. We had letters of recommendation to the inhabitants of the city, but not finding anybody at home, we went to sleep in the inn which was very comfortable.

"November 2nd. Schenectady is a city of about two hundred and fifty houses very beautifully situated on the Mohawk River. The inhabitants carry on with the Indians a very extensive trade in furs which amounts to near 1,200,000 francs a year. A few of the houses are of brick, and those which are wooden are comfortable and large. The easy communication by the Mohawk in Spring and the facility of navigation by boat up to Oswego afford to them an easy trade with the most remote parts. The trade activity begins in May and ends in July; it would be easy to open also a convenient communication between Oswego and Schenectady. The whole country, watered by the Mohawk, is very fertile; the grain produced here is abundant and of an excellent quality.

"Schenectady is an old Indian village of the Mohawk tribe, but these savages withdrew into the interior since the Europeans settled here. They were, however, mostly exterminated in the bloody wars between the French and British. Thirteen families of Onondaga and Tuscarora tribes have settled two miles from the city; we went to see them with an interpreter and a few bottles of rum. The man who accompanied us was a native of Alsace, a soldier in the detachment of Americans, who was taken prisoner by the savages at Niagara in 1759. Having been adopted by the Onondagas, he married a woman of this tribe, and after her death married a princess, a sister of the chieftain or the Sachem, as he is called here, of the Tuscaroras, who are widely famed for their bravery. Having such a leader and rum we were sure of a good reception. We asked them to dance for us; the princess after drinking two glasses of rum began to dance so furiously that we had to ask her to stop. She danced to the accompaniment of her own singing, and her dance represented the history of her marriage and the happiness of this alliance. Certainly there was much difference between her convulsive movements and the inimitable grace of Miss Guimard; but I found some resemblance between the barbaric tones and operatic songs: 'et manent semper vestigia ruris.' We encouraged the Sachem to dress in his native attire, to paint his face and to execute a few movements of the war-dance described by many Europeans as striking those present with such fear as to make them forget it to be only a play and to tremble for their lives. But, perhaps, we were disposed too much to laughter or, again, perhaps the war dance executed by one man cannot create such an impression. However, we refrained from laughter, with difficulty, not willing to give offense to the complaisant Sachem. I proposed that he sell me his wampum, fiddle and tomahawk, but 


\section{POLAND AND THE AMERICAN REVOLUTIONARY WAR}

he said that having no chance to buy new ones he does not want to part with them.

"We mounted our horses and after three hours of riding sighed for a good fire and a good dinner. We rested after our fatigues and prepared for new ones.

"November 3rd. We hoped to go to Boston by land and laid our plans accordingly. We left Albany in the morning directing our course towards Kinderhook Springs. The roads were so bad that we could make only eight miles before noon. We sent our men ahead and stopped at Moore's inn; my horse lost his shoe, and I in consequence trailed behind my companion. $\mathrm{He}$ became impatient and left me to travel alone. After sunset I lost sight of him and soon after also lost my way. For an hour I allowed my horse absolute freedom of leading me, but searching diligently I, at last, discovered a path; I followed it convinced that it must lead somewhere.

"Spurred a little by impatience and by the cold I allowed my horse to trot, and after three quarters of an hour I saw a light. I soon came to a house and hearing noise and loud outbursts of laughter I thought it was a public inn where a few jolly friends had gathered. What was my amazement when on entering the room I saw a man rolling on the floor in convulsions and seven or eight other persons jumping, weeping, moaning, yelling, crying and manifesting all the symptoms of extreme oddness. At first I thought that the man in convulsions was the father of the family and that grief over losing him disordered the minds of his children. None of these people paid any attention to my arrival, however; I approached the fire-place where a bright fire burned and impatiently awaited the end of this queer ceremony. The situation did not change for a quarter of an hour; then of a sudden the supposedly dying man rose to his feet and made three or four dangerous somersaults crying out in so shrill a voice that the hair on my head stood erect. At the same time one of the women began to twirl violently, and the rest of the gathering jumped and twisted their heads howling words in some unknown language. Others laughed loudly. This lasted about eight minutes and I cannot express all that I felt in that short time. I was unable to explain what sort of a house I had entered nor what kind of a people I had come upon. At last one of them tired of the dance became quiet for a moment. I took the opportunity of approaching him. 'By God'-I said to him-'be so good as to tell me where I am and who ye are.' 'Wait,' he replied, 'you shall know immediately,' and he began his somersaults again. I myself was tempted to execute a few similar jumps to harmonize with the society, but I was afraid lest it offend the madman whose countenance I did not like. So I gave up and quietly awaited the end of the ceremony. Slowly everything calmed down and a woman, about forty five years old, approached 


\section{A POLISH POET'S TRAVEL IN AMERICA IN 1783}

me. 'Stranger,' she said, 'we knew since yesterday that you would come here. We are very much satisfied with your arrival; probably you hate sin and love God, and if you wish we shall help you to be reborn.' I did not know what to answer to such a welcome. 'You are too good, lady,' I told her, 'but I am so dissatisfied with this world that I do not care at all to be born into it again.' 'I am mother of Israel,' she said. 'You have not yet been born for God.' I felt the truth of her words and became speechless. But the whole conversation embarassed me and did not in the least explain with whom I was dealing. I asked her that before thinking of my rebirth she tell me where I am and to whom I am speaking.

" 'You are in the house of God and, as I have already said, you speak to the mother of Israel; those you see are the children of God as pure as amber and as perfect as angels.' 'I do not understand this mystic talk,' I told her, 'and because I lost my way I should be eternally grateful to you if you show me the way to Springfield. I have a companion who would be uneasy about my fate, and I hope that your kindness will not forbid you to do me this favor.' I added: 'I hope to return to you tomorrow, and I desire nothing so eagerly as to be as perfect as an angel.'

“' 'Johnny,' she said to a young boy, 'go and show him the way to the Stone-house.'

"I bowed profoundly to her and mounted my horse. The brief talk with the 'mother of Israel' made me guess that they were some new religious fanatics; I asked my new leader a few questions concerning this, but he told me only that the mother of Israel was born in Manchester and that seven years ago she came over from England to proclaim the true faith."

At the inn Wengierski learned that these strange people were Shaking Quakers.

"November 4th. We were assured this morning that our plan of going to Boston through Green Wood was impracticable at this time of the year; they told us that we would not find any inns on our way and that it would be much better to return to New York and sail thence to Rhode Island, whence we could reach Boston very easily in two days. I complied with these suggestions only with regret because I remembered the adventure of Gen. Amherst who preparing for an expedition against Canada and planning to lead his army by the same way was warned by envoys from Massachusetts that the roads were impassable and that his army would die there of hunger. He did not change his mind, however, and led his army with the greatest facility. But because the way through New York afforded us another chance of seeing the amiable family of Chancellor Livingston from whom we experienced so many kindnesses, I easily yielded to these persuasions. We then returned by our old route and reached Clermont the same evening." 


\section{POLAND AND THE AMERICAN REVOLUTIONARY WAR}

The party landed at New York November 9th, after five days of lazy sailing, and witnessed there the departure of the Hessian troops who were just boarding the boats in the port.

November 13th, the diarist notes: "I was just informed that the English will leave New York November 20th. Gen. Washington will enter the city with the American troops at the same time."

The haste with which the poet made his journey did not allow him to wait to witness this great historical event. He left New York November 15th, missing the meeting with his distinguished countryman, Gen. Kosciuszko, who was one of the members of Washington's retinue on that day.

"November 15th. After many delays our boat which was to convey us to Rhode Island set sail. A very strong southwestern wind and the tide carried us with astounding velocity. We hur.ried at a speed of fourteen knots per hour. To reach East River one has to pass through a very dangerous channel, the Hell Gate. Besides the depth and reefs which make the passage difficuit there are also currents which one has to avoid carefully. Our pilot doubled his attention, and we passed those reefs without fear. We needed only a famous poet to immortalize these narrows far more dangerous than those of Scilla and Charibdis which undeservedly enjoy the privilege of frightening in imagination those who hear of them. But a long time will pass before New York will be as famous as Messina and before liberty will allure the Muses here.

"Probably you will not guess that after passing Hell Gate we entered what reminded us of Paradise. We sailed along the coast of Long Island and thousands of objects passing quickly before our eyes kept our minds always in tension, allowing us only brief moments for expressing our delights. At five the wind changed to the north and blew so violently that our small vessel was obliged to seek shelter in the port on Long Island, called Huntington. I was satisfied with the delay because I had the beginnings of the unpleasant feeling which precedes sea-sickness. The slightest movement makes me absolutely impotent.

"Soon after sunset we set sail and at seven in the evening passed the mouths of Connecticut and Thames Rivers. We saw New Haven, the spires of New London and Groton, the country of the brave Sassacus, the ancient King of Connecticut. This is the most populous part of the American continent. It distinguished itself by its Whiggism and by its enthusiasm for independence. It supported the war most liberally, furnishing a great number of militia, but, as I had said, the only two traitors of the common cause also came from this state.

"We expected to dine at Newport, but as nothing can be reckoned on and the changes come suddenly we were forced to land at Stonington. 


\section{A POLISH POET'S TRAVEL IN AMERICA IN 1783}

"Stonington is a small town situated on Narragansett Bay. As we did not wish to expose ourselves to new delays because of adverse winds, we took to horses and set out by land. It was Sunday. Scarcely had we made a few miles when near Pawcatuck River, on the border of Connecticut and Rhode Island, the inhabitants halted us and reproached us severely for profaning the Sabbath by traveling. We got rid of them with the greatest difficulty and were allowed to continue on our journey, but not until we assured them that we were public couriers.

"It is difficult to imagine how superstitious are the people of New England, how independent and thoroughly imbued with the republican ideas and the religious doctrines of Cromwell. Their old laws, called the Blue Laws, are full of oddities and nonsense. The first settlers of this colony brought to this land and left to their descendants a hatred of all authority and a love of independence which have been preserved till now. These people speak only of religion and of politics. They read only the Bible and newspapers. There is no city here without at least three newspapers, there is no home without several Bibles.

"The women are educated in these respects like the men and they can rival the theologians and the most cunning politicians in a dispute.

"After getting rid of these ardent defenders of the Sabbath, we made our further way through a country which though very stony, was quite open and densely populated. We entered Charlestown Township, R. I. The inn where we spent the night was excellent and its keeper one of the most inquisitive 'inquirers' of New England. Generally the New Englanders are very prone to ask questions. When asked about anything they will at once inquire where you come from, whither are you bound, what is the purpose of your journey, what did you do in the place where you came from, how long do you intend to stay and, at last, what's the news; and only at the price of answers to all these questions are you able to get information.

"November 17th. The State of Rhode Island which we crossed is flat, open and very densely peopled. At about two o'clock we reached Newport; it is a little town, very beautiful, though built of wood. Its port is very convenient. The French army remained here long and fortified very carefully the town and the whole island, but all these works are neglected today. The bay is very convenient and beautiful. We could remain in the town only twenty four hours; and though we had letters of recommendation, we were unable to see anybody. The women of Rhode Island are considered the most beautiful on the Continent.

"A very odd custom prevails in this State, as also in Connecticut, New Hampshire and in Massachusetts. When a traveler comes to a house, the greatest kindness he can show to the daughters of the family is to propose 'bundle' to one of them, that is, to sleep with her in one bed. But there are limits to this kindness 


\section{POLAND AND THE AMERICAN REVOLUTIONARY WAR}

which the traveler cannot transgress. They assure us that unpleasant consequences of this pleasing custom are very rare, and there is no stranger so vain who could boast that he violated these limits.

"November 18th. There is nothing interesting between Newport and Providence; Providence is a rather nice commercial city. We hired a carriage and arrived at Boston.

"November 20th. Now I am at the end of my journey through America. I intend to embark for Europe after an ex.cursion to Portsmouth. I shall sail in the stormy season to expose myself to the dangers of the sea and the severity of the climate.

"I shall take a boat sailing for Cork and will pass through Ireland, Scotland and England; I courted the ungrateful daughter, now I have yet to see the broken-hearted mother."

Thus ends the diary of Wengierski. From the fragments of his preserved correspondence it is evident that he remained two weeks in Boston. He was received there by the most prominent persons of society. One of his new friends was the beautiful Mrs. Tudor, full of grace and wit, mentioned also by contemporary French diarists.

On the eve of his sailing for Europe Wengierski wrote a very interesting letter to John Dickinson. It is in a certain manner a synopsis of his American impressions, full of confidence in the happy future of America, and sorrow which must have suggested itself to him from the comparison of the new Republic with his unhappy country.

"I have been constantly on the wing since I left you," wrote he to Dickinson, "my mind occupied by various objects, and my body tired by the fatigues of traveling. Just here I begin to rest a little and think that I could not use my time better than by writing to you. I have to congratulate you on your election and, what is more, on the evacuation of the British troops from New York. Your virtues and patriotic deeds assure you always one of the first places. Your satisfaction would be certainly great at the sight of a wolf leaving the lambs - it does not mean that I intend to compare the Americans to lambs; if they are as innocent, they have shown that they are not as defenseless. - But now that you are perfectly quiet and masters of your own abodes, what will you do, my dear Sirs? What will be your political views? What will be your domestic conduct? How far will your mutual jealousies extend? Who will have the power to stop them? Will you prefer the general good of the Continent to the happiness of your individual States? And will the rich inhabitant of Georgia selling dearly his indigo and his rice turn his mind to the inhabitant of New Hampshire unable to sell his timber and his potash? That public spirit which distinguished you during the course of the Revolution, will it survive in the midst of your commercial success? And the luxury that ever at- 


\section{A POLISH POET'S TRAVEL IN AMERICA IN 1783}

tends it, and the insinuations of enemies that would destroy your Union? Will your wandering Congress be able to excite reverence which is due to the representatives of the highest authority and which is indispensable in a Republic? And will the citizens revered for their talents and zeal have the inclination to leave their homes and expose themselves to a loss of influence and credit only to take part in the sessions of Congress and to see their names printed in the newspapers?

"Can you exist without a navy? If you will have it who will finance it? If you will not have it, who will protect your trade on the far seas? Who will avenge you if an arrogant English, French or Dutch captain takes a notion to scuttle one of your vessels sailing to China, the Indies or Archipelago? Your versatility is great; it beams with youth and strong health; but who can assure you, that the powers which protected you until now will not find some means to strangle you? A young lion is caressed, but when it acquires its strength it gets muzzled or enclosed and allowed only enough liberty to bite its enemies or arouse fear.

"I declare that in my opinion there does not exists a country that can vie with you in flourishing prospects; there is none, I know, where man is more free or where fortunes are more equal. Having traveled in the remote parts of your Continent, I have learned to compare the life of farmers to the life of patriarchs. Here I find the golden age, so lauded in ancient times. It is true that your creeks do not flow with milk, but your rivers are wide and deep; the hills do not jump like humming-tops, but they are fertile and fruitful, and the poor European farmer finds means after settling here to exchange his slavery for freedom and his wants for prosperity. Scarcely in two years his ideas enlarge; he becomes a man, and soon also a citizen. He is forced to quit his habits, his prejudices and even his vices, and to assume the sentiments and virtues of his neighbors. Yes, Sir, I have seen here the subjects of a bishop think freely on religion and heard the natives of Champagne reasoning. These are the notions, Sir, I have formed of your Continent.

"If you will have the goodness to relieve me of some doubts, you will add new favors to those with which you have already honored me. As I have always my country in view, I go begging instruction everywhere - not for my personal satisfaction, but to be able to fill honorably one day my duty of a citizen.

"When I think, Sir, that with three million people, and without money you have shaken off the yoke of such a power as England, and have acquired such an extensive territory, - and that Poland has suffered herself to be robbed of five million souls and a vast country, - I acknowledge, I do not understand the cause of such a difference.

"But whilst we are striving to recover our rights, have a care to preserve yours and remember always the maxim of Cicero - 'respublica res est populi, cum autem iniustus ipse po- 


\section{POLAND AND THE AMERICAN REVOLUTIONARY WAR}

pulus, non iam vitiosa, sed omnino nulla respublica est.' ${ }^{27)}$

"If the state of my country remains always the same, if the gods will not show pity to her fate, I will say to my countrymen: - Come, cross the seas, and insure to your children liberty and property! If my countrymen do not listen to me, I will say to my family : - Come! If my family refuse, I will go by myself and die free among you.

"I shall be very happy to see you, but should this be accomplished only at the loss of my country, may you never again see your friend."

This classically beautiful letter circulated in America for over a century as a letter of Gen. Thaddeus Kosciuszko. Even historians of national renown made this mistake of identification. The letter shows Wengierski in his noblest mood, - a patriotic son of Poland and a lover of America. It proves that his stay in America, however brief, did not fail to impress his mind favorably.

On December 7th, 1783, the poet left Boston and America and after forty days "during which he had to fight incessantly with the violence of adverse winds or with the monotony of the sea quiet," he landed in Ireland. His ship was almost wrecked near those shores.

Further biography of Wengierski is very short. He remained for some time in England, where he became one of the companions of the Prince of Wales, afterwards King George IV. He showed good intentions when leaving America, but was too much a child of his epoch to break off the old habits. The highlife to which he returned cut short his earthly existence. He died of tuberculosis in Marseilles, April 11th, 1787, only 30 years old.

So was wasted the life of the young Polish poet who could have been useful to his country if the ennobling influence of Revolutionary America could have also imbued him with the iron will of Kosciuszko.

The haste with which Wengierski visited this country influenced his American diary rather negatively. If he had allowed himself time, not only his literary acquisition would profit by it, but also the author himself, physically and morally. Keen observations, interesting narrative, the importance of the moment and of the events recounted, the picturesque description of primeval nature make his diary a welcome addition to American historical materials.

27) "Remember that the republic is of the people; when, however, the people are unjust, not only is the republic wicked, but it actually ceases to exist." 
X.

JULIAN URSYN NIEMCEWICZ IN AMERICA 

With my wounded commander ${ }^{1)}$ compelled to depart From thee, oppressed Poland, the pride of my heart; An asylum I sought o'er the dark rolling sea,

In the land of the noble, the brave and the free;

But e'en there the sad thought of my country would rise,

And tears of deep anguish would roll from my eyes.

In boundless savannas, where man never strayed,

Amid woods that ne'er echoed the axe's keen blade;

In the foaming abyss, where the clouds of bright steam

Round the falls of the roaring Niagara gleam;

And on the deep sea, when the white sails are spread,

Lo! the shade of my country, all gory and dead. 2)

Departure of Kosciuszko and Niemcewicz for America. - Their arrival in Philadelphia. - Yellow fever forces them to leave the city. - Their sojourn at Gen. White's house.

When Thaddeus Kosciuszko after his release from prison at St. Petersburg, in 1796, decided to go to America, which he always considered as his second country, he chose for his companion his former aid-de-camp, Julian Ursyn Niemcewicz. ${ }^{3)}$

Niemcewicz, like his "wounded commander," fell into the hands of the Russians on the field of Maciejowice and, like he, severely wounded spent two years in the dungeons of St. Petersburg. Kosciuszko's entreaties with Tsar Paul I effected his release, together with that of many other Polish patriots.

Niemcewicz was then thirty-eight years old and already a distinguished Polish poet and statesman. He was a very prolific writer of poems, novels, political and historical essays; some of which enjoy popularity in Poland even to this day. He was also an enthusiastic diarist. His memoirs cover nearly his whole life, but only parts of them have ever been published.

There are many paragraphs in his diaries which pertain to his ten years stay in America. They are all very interesting and not without historical value. His writings are as yet unknown on this side of the Atlantic, except for a small episode, ${ }^{4)}$ so it is proper to include at least a synopsis of them in this book; they

1) Gen. Kosciuszko.

2) J. U. Niemcewicz, List do Gen. Kniaziewicza, Paris 1834; translated by Paul Soboleski, Poets and Poetry of Poland, Chicago, 1881, p. 165.

3) Pronounced Niemtsevitch.

4) The only part of Niemcewicz's diary translated into English appeared in the Century Magazine, Feb. 1902, under the title "A Visit to Mount Vernon a Century Ago," by Prof. W. M. Kozlowski with foreword by Worthington C. Ford. 
pertain, indeed, to the post-revolutionary period, but include many personages prominent in the Revolution. ${ }^{5)}$

Kosciuszko and Niemcewicz with two Polish servants made their way to America by way of Sweden and England. Everywhere the people greeted the Polish hero and his companion with enthusiasm. This is especially true of England.

The party left Bristol, England, June 18, 1797, sailing aboard the Adrian, Captain Frederick Lee. Niemcewicz calls him "a hot radical" and says that he "had often brisk quarrels with him when he calumniated Gen. Washington." This shows Niemcewicz as an admirer of Washington even before he set foot on American soil.

The voyage was very slow because of adverse winds. At one time their ship was nearly wrecked in a collision with a merchant vessel from Jamaica. They reached Philadelphia, August 19, 1797.

"At four in the afternoon" - says Niemcewicz ${ }^{6)}$ — "our ship reached the shores of Philadelphia. The people informed of our arrival were already waiting with a carriage for Gen. Kosciuszko; after an English custom they harnessed themselves to the carriage and drew him to the boarding-house of Mrs. Loveson at Second St.

"After sixty one days on the sea it was a satisfaction to be on land again; but the impression of the monotonous watery space was so strong that when I awoke next day I seemed for a while to be still looking at the sea; soon I had a worse sensation; the large toe of my foot began to ache and became red and swollen, causing me intolerable pain. Happily Dr. Rush,?) the foremost physician of Philadelphia and an old friend of Kosciuszko, came to see him and examined me. He told me that my sickness is gout caused by the long sea travel, lack of exercise, salted food and bad water. The sickness came to me precisely at a time, when the state of health and the affairs of Kosciuszko, the question of his lodgings, my eagerness to see the city and the land so new to me, demanded much walking. I took to crutches and thus dragged myself to the banker and settled other

5) The list of bibliography used in the preparation of the essay is following: a) "Krótka Wiadomość o życiu i Sprawach Generała Waszyngton," Juljana Niemcewicza Pism Różnych Wierszem $i$ Proza, Warsaw, 1803, vol. I, p. p. 209-328; b) Juljan Ursyn Niemcewicz, Pamiętniki Czasów Moich, Paris, 1848; c) J. U. Niemcewicz, Dziennik Pobytu Zagranica, 21 lipca, 1837 - 20 maja 1841, Poznan, 1876; d) W. M. Kozlowski, "Pobyt Kościuszki i Niemcewicza w Ameryce," Bibljoteka Warszawska, 1906, vol. IV, No. 2; e) Prince Adam Czartoryski, Żywot J. U. Niemcewicza, Paris, 1860.

6) This paragraph and the four following are excerpts from Niemcewicz's Pamiętniki Czasów Moich, part 3, chapter II; the rest of chapters 1 and 2 is from his diary in Bibljoteka Warszawska, vol. IV, No. 2.

7) Dr. Benjamin Rush, (1745-1813), a signer of the Declaration of Independence. 


\section{JULIAN URSYN NIEMCEWICZ IN AMERICA}

necessary business for Kosciuszko. Fresh air, fresh, but plain food, restored my health within five days.

"We came to Philadelphia a few days after the session of Congress at which the immortal Washington retired from the Presidency. Gen. Kosciuszko found only few of his old acquaintances; among them was Gen. Mifflin who, though a Quaker, took up arms during the Revolutionary War and fought with renown. $\mathrm{He}$ is now Governor of Pennsylvania. ${ }^{8)}$

"I looked over the city with curiosity; the houses are built in the English style of red brick and unwhitewashed; the city was very well planned by William Penn. It is situated between the navigable Delaware River and a small creek called Schuykill. Between the two there extended fields for a quarter of a mile.

"Before we left Philadelphia, I had the pleasure of seeing the State Legislature in session. At eleven A. M. the Governor came to the Senate where both houses were assembled. Taking the place of the President of the Senate he made a speech in which he reported the situation of the Commonwealth of Pennsylvania, her finances and preventive measures undertaken against the yellow fever now raging here. He cited the reasons for vetoing the last resolution of the Legislature and recommended to its care some new legislation which should be passed, pertaining especially to schools and education. His speech was clear, simple and correct, without any rhetorical embellishments, such, in brief, as should be made by all officers who have no necessity of stirring men to action or who do not care to dispense flattery.

"The appearance of the assembly, though not imposing, was respectable. The Senators occupied the first seats. The Representatives those behind them. A large table covered with law books and papers stood before the desk of the President. Two clerks sat behind it. Everybody was in his everyday clothes and without swords. It was an assembly of a new people, unspoiled by luxury and composed of white-haired farmers, Quakers and others. However, those who know the country say that depravity already held sway, mostly in large cities, and that this outward simplicity which we admire in the representatives does not correspond with the true state of things.

"After finishing his speech the Governor bade farewell to the assembly and left. The Representatives also retired from the chamber of the Senate and went to their own room. One of the members made a few remarks about the Governor's veto, but others replied to him that the Governor only exercised his constitutional privilege.

"The subject of the debates was not very important, and everything was done amid the greatest quiet. The Senate communicated to the House a proposition to close the session because of cian.

8) Gen. Thomas Mifflin, (1744-1800), American soldier and politi- 


\section{POLAND AND THE AMERICAN REVOLUTIONARY WAR}

the epidemic, especially as there was nothing important on the calendar, and the time of the new elections was near. The session was closed sine die. Before the memuers left the chamber, the treasurer gave a check to each of them. Every member receives three dollars for each day on which he attends a session and traveling expenses.

"The same evening I saw a few members of the House returning home with small trunks bound with straps to their carriages. Whatever the people may say, this much is certain that as long as the representatives of this country will travel in such fashion, they need not fear corruption or tyranny.

"During our whole stay in Philadelphia the yellow fever, the debates about its cause, the disputes of physicians over the means of cure, the manifestos of the government, and the brutal arguments of newspapers greatly vexed the inhabitants. The ado was greater than the evil itself. Thirty six thousand inhabitants left the city. The streets were deserted and only funerals interrupted this solitude. Dr. Rush persuaded Kosciuszko to depart and Generals White and Gates, 9) his old friends, urged him by frequent letters that he come to stay with them. We decided then to leave the city.

"New Brunswick 10) is only sixty five miles from Philadelphia. With difficulty we hired a two-horsed carriage for thirty two dollars. Still more exorbitant was the cost of our board. We agreed to pay ten dollars for each of us two and five dollars for a servant weekly. However, Mr. Johnson demanded fifty dollars for twelve idays. This gives an idea of the extraordinary high cost of living in this country.

"We left Philadelphia on Wednesday at six in the morning.

"The state of agriculture, the buildings and everything show that the country was only recently settled by civilized people. Everything is new, everything, it seems, dates back only to yesterday. The roads are not yet kept up by the government and their bad or good condition depends on the season of the year.

"The cities consist mostly of only one street, longer or shorter. It is a common thing for the landed proprietors to live in towns and go daily to work on their farms situated nearby.

"Around Philadelphia one sees numerous villas, built mostly of wood, and distinguished by light and elegant architecture. All are painted white and have green shutters which gives them a cheerful appearance. One cannot find here, as in England, those beautiful gardens full of flowers, herbs and bushes whose verdure of many shades makes such an agreeable impression on the eye; nor can one see that great care in the upkeep of the surroundings of the houses. Everything here seems to be bent

9) Gen. Anthony Walton White, (1750-1803), an eminent Revolutionary soldier, and Gen. Horatio Gates.

10) New Brunswick, N. J., where Gen. White lived. 


\section{JULIAN URSYN NIEMCEWICZ IN AMERICA}

on making profit. There are no parks; the houses are surrounded by lawns which border directly on fields covered with grain, buckwheat or other seedplants.

"But one can see with satisfaction the astonishing progress of human labor and industry. Everything here is the work of one century; going further back into memory, we see nothing save the desert and savages. The traveler lives here in the present while in Europe thousands of objects transport him into the past.

"Ten miles from Philadelphia we passed Frankford, a small town of some sixty houses situated on a creek of clear water. The bridge thrown over the stream is rather nice and strong; all houses are new and of wood. We stopped at Washington Tavern to rest our horses. We met there a family whom the yellow fever drove out of Philadelphia and who found refuge here. The inkeeper avails himself disgracefully of their desperate situation and orders them to pay fifty dollars for the use of only two small rooms without board.

"We set out for Bristol through a flat country covered with farms. The fields are sown mostly with corn. They plant here pear-trees, peach-trees, and especially, apple-trees which grow among wheat and buckwheat; cider is the most popular drink here in Winter, and water with rum in Summer. The gigantic, primeval forests which entirely covered this country before the arrival of Europeans are now only little groves. I did not see any fir-trees; it seems, these are supplanted here by cedars. The most common tree is the oak; there are about ten species of it here; some are similar to ours, others have longer, narrower and dented leaves. After the oak the chestnut is the most popular tree. Often these trees are wreathed with wild vine.

"At noon we arrived in Bristol, a small town on the steep bank of the Delaware River. The country through which we passed after leaving Philadelphia was completely covered with corn fields and fruit-trees shutting off the view on every side; they left no space through which the eye could see far, and for that reason the country presented a crowded and gloomy appearance; but nothing could compare with the beauty and cheerfulness of the location of Bristol. The Delaware flows here in its full majesty; it is very wide and its waters are clear. Burlington, on the New Jersey side of the river, enlivens this rich, spacious and diversified landscape.

"A few vessels of some sixty tons were in the harbor. Aboard these were mostly fugitives from Philadelphia who, as many others, sought refuge in the country. We had the company of the Spanish Consul, an excellent entertainer, who told us that there is no freer and happier country than Biscai. The dinner without wine cost us two dollars. 


\section{POLAND AND THE AMERICAN REVOLUTIONARY WAR}

"We crossed the Delaware at Trenton, the capital of New Jersey, famous for Washington's victory over the Hessians which lifted the spirit of Americans oppressed by so many misfortunes.

"From Trenton the Delaware is no longer navigable. For want of time we could not see its waterfalls.

"Princeton is distinguished only because of its College; this rather imposing building dates to a period before the Revolution.

"By night time we arrived at Kingston, a town numbering about twenty houses. We stayed in an inn, very well kept by a Dutch family which, however, had completely given up their native language. On the other side of the road stood a large house; I was told that it belongs to an old sailor who after thirty years of risking his life at sea, decided wisely to enjoy at last the fruits of his labor in peace. We had a good dinner and good lodgings, all of which cost us only a dollar and a half.

"Next day, August 31, we set out on our way and at ten in the morning arrived in New Brunswick, where we stopped at Gen. White's house.

"The town is situated very low; it is distant from larger cities; its surroundings are quite populous and fertile, and provisions here are cheaper than elsewhere. The Raritan River, navigable for vessels up to sixty tons, is a good waterway. It discharges its waters into the sea near Amboy, nine miles from from New Brunswick. Amboy never could become a trading city because of its proximity to New York. The whole trade of New Jersey is conducted through the mediation of New York or Philadelphia. Nevertheless this State is probably well to do, and its agriculture is flourishing, as one can see everywhere well cultivated fields, quickly growing towns and prosperous inhabitants.

"The whole State abounids in iron ore; the earth is dark-red. Even very good copper ore has been found here. But the shortage and high cost of labor prevent its mining. Not till the laborers become more numerous than the demand of agriculture, will the excess population turn to industry. But this moment seems yet very far off; men here prefer agriculture to any other occupation, however profitable. When one part of the country becomes overpopulated, the excess of the inhabitants seek new homes in another part not yet inhabited. The North and West offer them spaces which in spite of the influx of immigrants from Europe will not be peopled for a long time. Nevertheless there are here seven iron ore mines and two foundries which produce four hundred tons of cast iron and five hundred forty tons of wrought-iron.

"The house of Gen. White stands on a hill a little distant from the city. The General fell victim of a swindler and lost a large part of his fortune. It is said that he lives from the estate of his wife. The bad state of his finances made him a 


\section{JULIAN URSYN NIEMCEWICZ IN AMERICA}

gloomy melancholiac though formerly he had been cheerful and sociable. Grief poisons his family life. His farm is neglected; it yields him only as much as is needed to support his family and slaves. In his home you cannot see the order which usually characterizes American homes. Everywhere may be seen the spirit of dissatisfaction and discontent.

"Mrs. White was born at Charleston, S. C., and though she is nearly thirty years of age, which is considered somewhat advanced in this country, she is still handsome. She has beautiful and large black eyes. They reflect the fiery character of the South. Her stature is tall and full which does not disfigure her, but rather adds much to her dignity. Her only daughter is five years of age. She is a child spoiled by too much tenderness as is the case with the majority of the American children. She may be heard sometimes saying to her mother:-

"'You damned witch!'

"Her slighest indisposition causes grief to the entire household. Once Mrs. White was asked which of two misfortunes she would choose: to lose her husband or her daughter.

“' 'To save my daughter,' she replied without hesitation, notwithstanding the presence of her husband.

"It is hard to believe, that the only stallion which the General has brings him more profit than his whole farm. He paid $\$ 1,800$ for it and rents it to neighbors for ten dollars. This happens a hundred or more times a year and brings him over one thousand dollars. He also had another stallion which he sold for two thousand dollars.

"The following Sunday I visited the Presbyterian church. I never liked the bareness of Protestant temples. The services lasted three hours.

"In New Brunswick as well as everywhere else in America, no poverty is visible; everybody who wants to work has here an assured income in quantity sufficient to live on it and, to save something besides. I did not see a single person in rags in the church, as is usual in Europe, not even a person badly clothed. The equality provided by law exists to the greatest extent possible as it should be, - i. e. that law is the same for everybody. Wealth and office do make some distinction, namely that persons belonging to these classes and allied by education and wealth live among themselves only occasionally coming into contact with the rest; but in daily life all are on an equal footing. The poorest farmer, a farm-hand, even a servant never stands with uncovered head before a wealthy man. Everybody is titled 'Sir.'

"But notwithstanding the laws and customs, even here some try to distinguish and raise themselves above others. As there are no titles like those of Prince, Count, Baron, the inhabitants retain the titles of rank which were used in the Revolution; so 


\section{POLAND AND THE AMERICAN REVOLUTIONARY WAR}

they address persons: General, Colonel, Major, or if in the civil administration: Governor, Judge or Doctor so-and-so.

"The most prominent persons in New Brunswick are: General White, Colonel Bayard, and Judge Paterson. ${ }^{11)}$ Their families are connected by kinship and live in close contact. They entertain at teas and dinners to which they invite one another in turn. I was present at one of these receptions. The dinner consisted of two or three roast capons with sauce and oysters, roastbeef, cooked mutton, fish or ham. The second dish was pudding or almond cake, marmalade or confectionary. Afterwards the table cloth was removed and fruits, almonids, raisins, chestnuts and wine were served. They drink to the health of the President, Vice-President and Congress. The ladies leave the company and the gentlemen remain chatting for hours, drinking toasts. Then they join the ladies and drink coffee or tea together."

\section{2.}

At Gen. Gates' home. - Return to Philadelphia. - Meeting with President Adams. - Little Turtle and Kosciuszko.The unexpected departure of Kosciuszko.

"We left New Brunswick on Saturday, September 9, to visit Gen. Gates. We traveled through a flat country, cultivated and peopled in the same manner as that we saw on our way from Philadelphia. Springfield, Elizabethtown and Newark are the little towns through which we passed. After crossing saltmarshes and a dam several miles long, we came to Hoboken very late in the evening. We found the inn full of sailors and tramps; all were very jolly and tipsy for the most part; they danced in the room downstairs. We had to dispense with dinner because everything was consumed; we slept in uncomfortable beds and paid very dearly for our lodging the next morning.

"Sunday morning, September 10; the view of North River and the towers of New York recompensed us somewhat for the bad shelter. We crossed the river in a sail-boat with favorable wind and tide. The transportation cost us ten shillings. It is rather much, but at least, the people who put our carriage and baggage on the boat, a task which demands not a little labor, do not ask tips as in Europe, especially in Italy. La bona manzia and Trinkgeld are almost unknown in America. We landed near the new prison, avoiding in this way the burdensome passage

11) William Paterson, (1745-1806), jurist and politician, delegate to the Continental Congress, U. S. Senator, Governor of New Jersey, Justice of the Supreme Court of the U. S. - John Bayard, (1738-1807), distinguished Revolutionary soldier. In 1788 , having retired from active business in Philadelphia, and having been compelled to part with his estate in Cecil County, Md., in consequence of his patriotic sacrifices during the war, he removed to New Brunswick, and built there a handsome house, in which he entertained many distinguished guests. 


\section{JULIAN URSYN NIEMCEWICZ IN AMERICA}

through the town. ${ }^{12)}$ We made two more miles through a road surrounded by villas and gardens. At last we were shown the gate of the house of Gen. Gates ${ }^{13}$ ) and soon found ourselves before a beautiful house, decorated with a peristyle of Corynthian columns.

"We were met at the threshold by the victor of Saratoga. $\mathrm{He}$ is an old man, about seventy-five years of age, still quite lively, kind and very cheerful for his age.

"Except for the battle of Camden, good luck always favored him. Born in England, he was in the British service for a long time. During the Revolution he devoted himself with enthusiasm to the American cause and was made General from the beginning. After peace was signed he received, beside his pension and lands granted by Congress, also a large grant of land from Virginia. He sold all this and accumulated a large fortune; this he increased through his marriage with Mrs. Gates.

"Such a wife is a real treasure for this old man. She is fifty years of age, still beautiful and of the happiest temper. Only she could render agreeable the indispositions and griefs of such an old age. When one sees how they live together it seems that this is the first year of the marriage of a twenty year old couple.

"Gen. Gates is no less fortunate in his financial affairs. The farm which he rents is located three miles from New York; it has nearly two hundred acres of land, a magnificent residence, green-house, fruit and vegetable gardens, meadows, etc. It belongs to one Kruegers, a rich merchant, who thinks he is not rich enough. His greed induced him to make the worst possible bargain. Speculating on the old age of Gen. Gates and supposing that his wife is also near her grave, he rented them the farm for life for a consideration of $\$ 5,000$. What was his astonishment when he later saw that Mrs. Gates was hardly forty years old and in the best of health. Mr. and Mrs. Gates occupy the farm already seven years. They keep for themselves only the greenhouse, the garden and the meadow for their six cows and three horses; they sublet the rest for nearly three hundred pounds and thus they have earned their principle long ago. They have a man who manages their farm for two hundred dollars yearly and provisions. Their other servants are a negro, a woman-cook, and a negress-servant. All are free, for the General has liberated all his slaves.

"During our whole stay with Gen. Gates we had innumerable visits in the morning hours. It is impossible to remember all persons, but I will mention some of them.

12) Kosciuszko wished to avoid the ovations of the inhabitants.

13) His house stood on the present corner of Second Ave. and 24th Str. 


\section{POLAND AND THE AMERICAN REVOLUTIONARY WAR}

"We saw a dozen Livingstons, men and women, among them Edward and John whose wives are very beautiful. ${ }^{14)}$ Their homes were the first ones I saw in America managed in European style: - nice carriages, magnificent horses, servants in livery - briefly, every luxury not at all democratic.

"The Livingstons occupy the same position in the State of New York as the family of Potocki in Poland; they are a very numerous family and hold vast possessions. I was told that they have nearly six hundred tenants settled upon their lands and dependent upon them. Probably this gives them much influence in the elections. They are rancorous enemies of the present Governor of New York, Mr. Jay, ${ }^{15)}$ and because he is favored by the government this suffices for their siding with the opposition.

"The numerous family of the Stephensons, Misses Broome, 16) Miss Johnson, the niece of Mr. Smith 17) of Baltimore, visited us also, as well as Mrs. Winnings of Delaware, who was young, comely, very interesting, a good singer and painter, and whose husband, in spite of all her advantages, was a drunkard and passed his time with his negresses, to the neglect of his wife.

"Our neighbors were Mr. and Mrs. Vilette. Mrs. Vilette is a famous chess-player, bright and well educated, but she likes the city more than it becomes the wife of a Quaker. Her husband is very good, much attached to his wife and also to his garden which he cultivates himself.

"Another neighbor is Mr. Brigide, a prattler and buffoon."

At times Niemcewicz went to look over the city. He visited a local theater. "It was not yet ready, without a floor, so that we had to stand on the sand." At another occasion Gen. Gates went with Niemcewicz to the Whig Club and Hell Gate Club. On his return he saw the General buying meat, fishes and vegetables. That was an unusual sight for a European. "I looked with greater respect at the venerable old man buying provisions, than I would look at a Russian fieldmarshal giving audience to a crowd of liveried lackeys."

"With great regret we left the house of General Gates and his kind wife. We placed Gen. Kosciuszko in a boat with great difficulty, and once more embracing Gen. Gates who accompanied us to the bank of North River, we crossed it. We soon passed the road which was built by a company through the salt-marshes and about one Polish mile long. The hay from neighboring meadows is very crude. The cattle eat it when there is no better;

14) Edward Livingston, (1764-1836), American statesman. In 17951801 he was a member of Congress. - John Henry Livingston, (1746-1825), clergyman, at that time pastor of the Dutch Church in New York.

15) John Jay, (1745-1829), author of the Jay's Treaty.

16) Daughter's of John Broome, (1738-1810), merchant, LieutenantGovernor of New York in 1804.

17) Robert Smith, (1757-1842), American statesman, Secretary of Navy (1802-1805), Secretary of State (1809-1811). 


\section{JULIAN URSYN NIEMCEWICZ IN AMERICA}

it is also used as a fertilizer. The marshes extend very far and are still seen near Elizabethtown as well as near the road to New Brunswick along the Raritan River. Between Newark and New York, at a distance of ten miles, one crosses two Passaic Rivers. Both of them have very clear waters and are navigable for small vessels. To facilitate the crossing there are two beautiful bridges.

"Newark is a cheerful town, having several nice houses. Because of its proximity to New York it will probably grow very quickly. It is only six miles from here to Elizabethtown where we arrived at noon."

After a three-weeks stay at Elizabeth, the travelers returned to Gen. White's house at New Brunswick, where they had occasion to meet President Adams.

"The citizens elected a reception committee," narrates Niemcewicz; "its President and Vice-President were to keep order at the table and to greet the highest officer of the country. Several evenings were devoted to discussing this important affair. At last Mr. Adams came, but two hours earlier than the appointed time. Nothing was ready; thus we witnessed foot and horse militia running to and fro, officers putting on their wigs precipitately, dandies running with unbuckled shoes. The gun salute was heard half an hour after $\mathrm{Mr}$. Adams made himself warm beside a fireplace.

"But soon order was restored. At one o'clock in the afternoon I was introduced to Mr. Adams. He sat near the fireplace, with Mr. Malcolm, his private secretary, a young man about twenty years of age, and read a paper. I saw before me a small and plump man dressed in black, with his head much powdered, and wearing a cue. His face seemed to me kind-hearted and honest, but not without a little malice. He greeted me very kindly and asked about Gen. Kosciuszko and Lafayette.

"I passed then to the next room where I found a counterpart of Mr. Adams in the person of Mrs. Adams. This small, short and stout woman is accused of a horrible offense: they say she uses rouge. If her appearance is not charming, she has indeed a keen and cultivated mind. She was accompanied only by her niece and a servant.

"At two o'clock Col. Nelson, President of the reception committee, arrived with Gen. White and with a delegation of citizens to the house occupied by the President. Mr. Nelson in the name of all citizens read a speech full of expressions of their attachment to the Constitution and to the highest official of the country. Mr. Adams read his reply, exchanged a few words with some of the delegates, shook hands with everybody, and left.

"At three the ceremony was repeated to invite him to the dining hall. He went there accompanied by a crowd of citizens and about thirty militiamen in uniforms. He was greeted by 


\section{POLAND AND THE AMERICAN REVOLUTIONARY WAR}

the lowering of flags. The table was covered for sixty persons; roast-beef, turkey, etc., were served in adequate proportion.

"During the dinner, Mr. Gass, six feet high and over seventy years old, a potter by trade and tattler by habit, left his seat across the table, came to the fore where the President was seated and, pushing Gen. White aside, sat down at Mr. Adams' side and began to entertain him with the coarsest jokes. The President laughed and, surveying the gigantic height of his co-banqueter, said :

" 'You should have been born in the dominions of the Prussian King, you would be the pride of his guard'.

" 'If I had to be the second person in his kingdom I would not like to be born there,' replied the potter.

"' 'Nor I, even if I were the first one,' said the President.

"After dinner followed the toasts early prepared by the committee. They drink as many of them as there are States in the Union, i. e. sixteen. They mostly express sentiments and wishes for the preservation of the laws, constitution, liberty, peace, agriculture, trade, etc.

"After the President left, a toast to his health was drunk and others less serious were in order. The company became gay and noisy and the banquet lasted until ten P. M.

"The President and Mrs. Adams arrived at Gen. White's house for tea in the evening. The following day both left very early. They traveled in only two carriages, comfortably but simply, and were accompanied by only one servant on horse. About thirty militiamen and all prominent citizens in carriages escorted them half way to Kingston. There they formed a line, and the President took leave of each of them separately. Gen. White and I accompanied him to Kingston.

"Next day, November 20, I took the stage to Philadelphia to find lodgings for Gen. Kosciuszko. I reached Philadelphia on Sunday morning and stopped at a dirty and miserable inn called 'The Eagle and Harp' at Second Street North. With the help of Dr. Rush I found a dwelling as small, as secluded and as cheap as I had instructions from Gen. Kosciuszko."

Niemcewicz returned then to New Brunswick to bring Kosciuszko.

"With great regret we left the hospitable and quiet house of Mr. White and reached Philadelphia on the next day. We made our quarters at No. 172 Third St. South, with Mrs. Relf, in a very small house occupied by students of medicine and young artisans. Their cheapness induced us to choose these rooms. Kosciuszko had a small room where he could receive not more than four persons at one time. My room was still smaller and, because it was not heated, I used it only as a sleeping-room. I was obliged to roam through the streets or to lie in wait when the table in the parlor was not occupied where I could write and read. 


\section{JULIAN URSYN NIEMCEWICZ IN AMERICA}

"February 22nd. The people celebrated Washington's birthday. All ships were decorated already in the morning; there was also a gun salute.

"Mr. Adams, the present President, was invited to the festivity. But, touched because his predecessor, no longer in office, is feted and revered more than himself, now occupying the chair of the President, he immediately replied to the leaders of the celebration with a letter full of bad temper, in which he refused to attend.

"The celebration took place in the Circus. This is a circular building, badly painted from the foundation to the top. Its gray and black colors completely dimmed the light of hundreds of candles suspenided on iron rings. The dresses of ladies with the preponderance of white and feathers, though very elegant, appeared to a disadvantage in this gray gloominess. The music occupied the stage in the middle. The ropes drawn from it divided the room into eight partitions. In these partitions the people danced. Nobody was encumbered, but neither was anyone gay. Only the wife of the Portuguese ambassador wore jewels. But the eyes of Mrs. Law, nee Custis, the granddaughter of Mrs. Washington, had a more beautiful brightness.

"Little Turtle, the Indian chieftain, occupied a box. He was dressed in the uniform of an American General with large epaulets. It seemed that he was satisfied with the spectacle. $\mathrm{He}$ is a very intelligent man; his views are sound and sane; there is no perversity in him,- - the result of erroneous judgment.

"He came here to negotiate with the government the question of a boundary which was to be drawn, and other matters pertaining to his nation, the Miamis. His main demand is that the American government give promise to forbid the importation of spirits to the Indians under most severe penalties. $\mathrm{He}$ knows well the fatal consequences of their use, and the hypocritical policy of the whites who support the discords among them and draw them into their own controversies in order to brutalize them with spirits; who, briefly, use every means to keep them in ignorance and to gradually annihilate them.

"He clearly sees the advantages of civilization and this makes him sad.

" 'Dio not speak to me about your superiority,' he said, 'if you do not wish to provide means which would help my nation to attain the same advantages.'

"He came to see General Kosciuszko and presented him with a tomahawk. Kosciuszko gave him his felt-cloak. The chieftain saw spectacles and seemed to be eager to acquire them. Nothing could equal his joy when Kosciuszko presented them to him. He could not comprehend how glasses can enlarge objects and seemed to experience an endless pleasure in seeing them so changed.

"'You have given me new eyes,' he exclaimed. It was the only moment when he seemed savage to me. Other Indians, 


\section{POLAND AND THE AMERICAN REVOLUTIONARY WAR}

Chickasaws and Six Nations, came also to Philadelphia. But they differed from Little Turtle in all respects. The government supplied them with everything during their stay.

"The session of Congress just opened. Gen. Kosciuszko was not yet paid for his services in the Revolutionary War. A bill was introduced at the session and by unanimous vote it was resolved that he be paid the whole sum with interest. It was about eighteen thousand dollars which he deposited for interest, keeping only a part of it.

"Our stay in Philadelphia during the winter of 1797-8 gained for me many new acquaintances. I made friends with many members of Congress and with many citizens. Among them was Mr. Jefferson ${ }^{18)}$ with whom I became acquainted when he was Minister to France; Mr. Gallatin, ${ }^{19)}$ born in Geneva, one of the most eminent members of Congress who early immigrated to America and held the office of Minister and other high offices in the Republic; Mr. Law, son of the Bishop of Carlisle, who married the granddaughter of Mrs. Washington, an intelligent and excellent man; ${ }^{20)}$ Judge McNeal, whose daughter married Marquis de Caza-Irujo, the Spanish Minister; Mr. Patterson, who was afterwards President of the American Philosophical Society. 21) At the motion of Vice-President Jefferson I was elected a member of this society. To commemorate this event I presented the last Polish gold coin minted during the Polish Revolution of 1794 to the collection of the society. It bore the inscription: Stanislaus Augustus, King of Poland, Grand Duke of Lithuania.

"I must not pass over in silence another acquaintance which I made that Winter in Philadelphia. The Duke of Orleans, who was afterwards Louis Philip, King of the French, lived there with his two brothers, Duke de Montpensier and Duke de Beaujolais. They often visited Gen. Kosciuszko in the evenings, and he also visited them. Having been sent to America by the Directory they lived here as common citizens, wore tri-colored cocades and were obliged to report every Sunday to the French Consul, Mr. La Jambe. They were accompanied by a French noble, Mr. Montjoie, who was much attached to them. All these were excellently educated and modest. Montpensier was a very good designer. Beaujolais was about fifteen years of age, lively, witty, resembling much Louis XIV. After spending the Winter at Philadelphia, they set out in the Spring to visit the outlying provinces of the United States and then to descend by the Mississippi to New Orleans. When they came to bid farewell to Kosciuszko, he presented the youngest, the Duke de Beaujolais, with a pair of fur-boots. The present was accepted with joy and gratitude.

18) Thomas Jefferson.

19) Albert Gallatin.

20) Thomas Law, (1759-1834), the husband of Eliza Parke Custis.

21) Robert Patterson, (1743-1824), professor of mathematics in the University of Pennsylvania, director of the United States Mint in 1805. 


\section{JULIAN URSYN NIEMCEWICZ IN AMERICA}

I often met them later at New York and was frequently invited with them to dinners.The Duke de Orleans, then already wealthier, sometimes gave small dinners; once he invited me, but I replied that I could not be at his service because Mrs. Church had invited me previously. ${ }^{22}$ ) Could I have known then that I had refused the future King of France?

"I also made some acquaintances among the Quakers: Pemberton, Elliott, Logan. ${ }^{23}$ The last was a descendant of William Penn, the founder of Philadelphia. He gave me some of the letters of his illustrious progenitor, and an instrument invented by him to write at night. These I deposited in Pulawy ${ }^{24)}$ together with a cup which I had later received from Mrs. Washington.

"It was customary for young girls to visit Gen. Kosciuszko. $\mathrm{He}$ drew pictures of some of them and also of Mr. Jefferson.

"Spring came; April adorned the trees with leaves, the flowers were budding. In the first days of May Kosciuszko more often conferred with Jefferson, and one evening he announced to me that he was about to go to France to learn whether he could do something for our unhappy country. 'You better remain here,' he said, 'because if there is no hope I shall return, buy a farm and we shall live together.' He, really, sailed soon with a passport as a German Baron, leaving his servant Stanislaus and myself. I ordered the servant to take the things of the General and bring them to Mr. Jefferson. On opening a drawer I saw a package addressed to me. It contained a hundred dollars. This amazed me and as Stanislaus longed for his old country, I gave him the money and shipped him to Hamburg. Libiszewski ${ }^{25}$ ) left us before and being an excellent musician went to Havana, Cuba, where he soon made good money. But a year later he fell victim to yellow fever. I was sincerely sorry for him; he was a good and amiable young man."

The departure of Kosciuszko was entirely unexpected. Except for Jefferson whom he especially befriended, nobody knew of his plans, not even Niemcewicz, to whom he disclosed them partly not earlier than on the eve of his departure, May 4th, 1798. The reasons of this secrecy were political. Kosciuszko had just received news that Napoleon started the organization of the Polish Legions, and he saw in this move a ray of hope for Poland, but thought it prudent to act very cautiously, especially since the relations between the United States and France were then strained.

22) Mrs. John Barker Church, the daughter of Gen. Schuyler.

23) All three were eminent families of Philadelphia. Niemcewicz's acquaintance was probably George Logan, (1753-1821), statesman and philanthropist.

24) In Poland, the seat of the Czartoryski family.

25) The young Polish noble who accompanied Kosciuszko and Niemcewicz to America. 


\section{POLAND AND THE AMERICAN REVOLUTIONARY WAR}

To divert public attention, he directed Niemcewicz to tell everybody that he left for health resort in Virginia, and to go South three days after his departure as if to follow him there.

3.

Niemcewicz meets Washington. - Two weeks at Mount Vernon. -Sentiments of Washington toward Poland.- "Once a great man wept o'er Poland's fall."

"Now I am alone, deserted on foreign soil, without means and forgotten by my people," complains Niemcewicz in his diary. "I cannot return to Poland, neither can I remain here, nor find any means of support.26)

"I roamed through the streets of Philadelphia for a long time. How I wished that in place of my literary education I had some professional training or skill in some trade."

His moral suffering was augmented by the necessity to lie to everybody who asked him about Kosciuszko. "Kosciuszko's departure, so sudden and secret, evoked universal astonishment. People deluged me with questions. I had to lie a thousand times a day."

Then, in accordance with the advice given him by Kosciuszko, he left Philadelphia for the South.

"I had resolved to see Gen. Washington, the founder of American liberty, and with that intention set out to the newly established capital bearing his name. My friend, Mr. Law, who married Miss Custis, the granddaughter of Mrs. Washington, was already living there. I was received with kind hospitality at his house. I found in this future capital of the powerful country nothing else than a large building, the Capitol, and the President's residence, neither of them yet completed; the proposed streets were only laid out; a few houses were scattered here and there. A small river which flowed nearby was called the Tiber; was it pride or was it prophecy of the future greatness that caused the Americans to give that name to this river? Apart from this there was nothing but shrubbery and woods, and in this great capital I roamed and hunted. How the people will wonder at this a hundred years hence!"

From Federal City, May 27th, 1798, Niemcewicz wrote to Jefferson:

26) The first meeting of Niemcewicz with Washington and his later stay at Mount Vernon were the episodes which Prof. W. M. Kozlowski translated and published in the Century Magazine (Feb. 1902). He used for this purpose the rough copy of the diary. The following account embracing this whole chapter is from Niemcewicz's biography of Washington published at Warsaw in 1803 (J. U. Niemczewicza Pism Różnych, val. I, pp. 209-328). The texts differ somewhat in construction and wording, though their substance is the same. Both give an excellent picture of Washington and his life. 


\section{JULIAN URSYN NIEMCEWICZ IN AMERICA}

"General Washington and his wife were in the city to see their granddaughters, Mrs. Peters and Mrs. Law. I was introduced to him; he received me very politely, asked about the health of Gen. Kosciuszko with some interest, but he was generally too much reserved and less curious and inquisitive than I expected."

Niemcewicz describes this meeting in detail in his diary:

"May 21, 1798. My worthy host, Mr. Law, on his return from Georgetown whither he went to finish the affair with the farmers who cheated him, informed us that Gen. Washington arrived at the residence of Mrs. Peters, the granddaughter of Mrs. Washington by her first marriage. We decided to visit the hero of America that same evening. So at about six o'clock we set out, Mrs. Law with Chevalier Freire, the Portuguese Minister, in his carriage, and I with her husband in a ladder-wagon.

"The house of Mr. and Mrs. Peters is situated at the end of the enormous circuit destined to be the future capital. Tender anxiety, laudable curiosity overcame me completely. I remembered how on reading the works of Plutarch I was interested in the most trifling circumstances pertaining to great men; I wondered what might be the cause of it; it seemed to me that this might be attributed to man's desire to apply everything to himself; when reading, one gladly puts himself in the place of the hero whose life he has before him. Then, when he finds that, despite the deception of self-love, he is not able to equal the hero in his great deeds, he likes to resemble him in his private life, to find some likeness between one's self and the hero; and if extraordinary talents and superiority of the hero humble him, he enjoys knowing that the hero was also sometimes human like himself. Partly to justify this opinion, but much more to preserve for myself a very dear keepsake, - if I cannot like Plutarch describe with master pen the character and deeds of this great man, I at least note here some particulars pertaining to his person and to his private life.

"At about seven in the evening we arrived at the home of Mr. Peters. You may imagine how my heart was beating. I was to see the man for whom I had a deep respect since my youth. I saw Washington through the window and recognized him at once. About ten persons came toward us, but I saw no one except him. Mr. Law introduced me to him. He grasped my hand and shook it.

"We entered the room; I took a seat beside him; I did not speak, but diligently observed him.

"His stature is majestic and combines dignity with amiableness. His portraits which I saw in Europe bear only a slight resemblance to him. He is about six feet high, strongly built; his nose is oblong, his eyes blue; the lower part of his face, partic- 


\section{POLAND AND THE AMERICAN REVOLUTIONARY WAR}

ularly the jaw, are a little receding; his hair is thick. ${ }^{27)} \mathrm{He}$ was dressed in a dark-brown tail coat, black stockings and breeches and satin waistcoat.

"He began the conversation by asking me about Gen. Kosciuszko, about his health, his journey to the springs, etc. The first words I spoke to this great man were a lie. That is what the mysterious departure of Kosciuszko brought me to. Washington asked me the following questions:

" 'How long are you in this country?'

“' 'Eight months.'

" 'How do you like it?'

" 'I am happy to find in this country those blessings which I so warmly desired to see in mine. To you, General, America is indebted for her freedom.'

"He bent his head modestly and said to me:

" 'As every honest man, I wished well to your country with all my heart.'28)

"The above words he said with tenderness.

"The questions about Kosciuszko again returned and renewed my tortures. Happily the small daughter of Mrs. Law, sixteen months old, came in. He called her, gave her some dried fruits and embraced her, giving the rest of the fruits to her mother and saying, 'keep this for your little Law.'

"The conversation turned then to agriculture, always a favorite subject with the General. They talked about the then prevailing drought, about the losses which it would cause in tobacco, corn and in wheat.

"I approached Mrs. Washington. She is of small stature, has bright eyes and is lively and extremely kind. She was dressed in a gown of white stuff, fastened about with pins, a bonnet of white gauze with a ribbon of the same color, exposing her entire forehead and the larger part of her gray hair, which was done up from behind in a cue. She was once a famous beauty in America and even now there is something pleasing and attractive about her.

"I spoke with her about her granddaughter and how little likeness I found between the portraits of Gen. Washington and himself. Mrs. Washington asked her granddaughter, Mrs. Peters, to play the clavichord, and she played an old sonata The Battle of Prague, then the most modern piece of music in America.

"Tea was served. I found an opportunity to be near the General. He spoke with praise about an address of the town of Norfolk to the President.

27) The original diary of Niemcewicz thus describes Washington: "He is nearly six feet high and very strongly built, he has an aquiline nose, blue eyes; his mouth and particularly his lower jaw, are large."

28) Original copy: "I always wished well to your country, and that with all my heart." 


\section{JULIAN URSYN NIEMCEWICZ IN AMERICA}

“' 'Did you know, General,' asked Mrs. Law, 'Mr. Jones who was killed in a duel by Mr. Livingston?'

“' 'I think I saw him,' said Washington, 'but I was never on intimate terms with him.'

"Somebody interrupted with the observation that the bullet shot by Jones at the adversary passed right near the nose of Livingston.

"'What an aim!' said the General, 'how could he have missed him! We all know the noses of the Livingstons!'

"I was glad to see the old man in good humor and was convinced that those who wrote that he never smiles idid not see him save in the camps or in the President's chair. He asked me then whether I had traveled much in the United States. I replied that I have not yet been farther than New York and that I was surprised to see how this new country made so much progress in agriculture and population.

"'The eastern States,' he said, 'are most advanced in culture and population.'

"'They must have been the first which the Europeans settled,' I observed.

" 'On the contrary,' he said, 'the oldest European settlements were founded here, then in New England. Those states are divided into townships which is very favorable to the maintenance of good order and to the establishment and progress of all public enterprizes and legislatures. The people are industrious and ingenious; every farmer, even the poorest lives independently.'

"'I must acknowledge,' I said, 'that these people are the freest and happiest in the world.'

" 'Provided," interrupted the General, "that they do not spoil their happiness.'

"Dusk came and we rose to depart. Gen. Washington conducted us to the door and taking leave of us he said:

" 'I shall be very happy if you will visit me at Mount Vernon; I hope you will not refuse me.'

"He then embraced the little daughter of Mrs. Law. The next day Mrs. Peters invited us to dinner. We went there; I was immensely happy because of my new acquaintance.

"I dined in the company of the General. The subjects of the conversation were the buildings which were to be erected to house the government departments; their cost amounted to ninety six thousand dollars. The company discussed the difficulty in erecting the required number of buildings so that Congress could move into the new city within three years. Gen. Washington said jokingly: 'If there are not enough houses, Congress can camp.' After dessert the ladies left the room; glasses of Madeira began to circulate, but modestly; while drinking we discussed agriculture, business and politics. 


\section{POLAND AND THE AMERICAN REVOLUTIONARY WAR}

"May 23, Wednesday. General and Mrs. Washington arrived at Mrs. Law's, where I lived, to spend two days; during this whole time he was kind and attentive; besides agriculture, he spoke also of natural history and of the products of America, and these he knows very well. He observed a strict silence on politics and was absolutely reserved, to such an extent that he never questioned me upon the subject of the unhappy Polish Revolution, nor upon the least thing connected with it."

The friendship between Washington and the young Pole grew fast. On Thursday they both visited a local sugar refinery and the port.

"The General amused himself by playing billiards while he was staying with Mr. and Mrs. Law; and though he had not played for twenty five years his skill and attention made up for his want of practice.

"May 25. Between seven and eight in the morning, eager to see the effects of the last rain on his fields, the General left us. He and Mrs. Washington again invited me to Mount Vernon. I shall certainly keep my word to them."

The great American always kept an open house. Rarely was there a day without guests at Mount Vernon. Especially welcome to Washington were his old comrades-in-arms, but not infrequently he was visited also by strangers who were attracted by his fame.

Washington always highly esteemed Gen. Kosciuszko. Niemcewicz owed his invitation to Mount Vernon, above all, to these sentiments of the old hero towards Kosciuszko, and also to the good impression he had made on Washington.

Soon the poet had the chance to keep his word. On June 2, he arrived at Mount Vernon with Mr. Law and spent there two weeks diligently entering all particulars of his stay into his diary:

"June 2. At eleven in the morning Mr. Law and I set out on horseback to Mount Vernon; we crossed the eastern arm of the Potomac by ferry and followed the Maryland bank. Washington City, or rather the ground destined to be the future capital, can be seen from the bank rising amphitheatrically. After having made four or five English miles we arrived at the point opposite Alexandria.

"We spent twenty five minutes in recrossing the Potomac. I stopped in Alexandria to buy a pound of tobacco from Mr. Atkins, the merchant; I paid for it nine Polish zlotys which is an exorbitant price in a country which is the motherland of all kinds of tobaceo.

"We followed the way intersected by elevations and covered with beautiful forests. After traveling seven miles, we arrived at the foot of a hill which marks the boundary of Gen. Washington's possession. We passed along a road newly cleared through a forest of large oaks. Soon we saw the hill on the top of which is situated the house of Mount Vernon, quite spa- 


\section{JULIAN URSYN NIEMCEWICZ IN AMERICA}

cious, one and a half stories high and topped with a small cupola; it is as white as milk and the blinds are painted green. The house and yard are surrounded by a ditch instead of a fence; the ditch is faced on both sides with brick; on each of the four corners of the ditch are beautiful little turrets, but they are destined not for defense; they are simply toilets. Two grass-plots, one circular in front of the house, the other larger and irregular, form the yard. Various trees, shrubs, plants and flowers are scattered over it in artistic disorder.

"We entered the house. General Washington was in the field, but his wife appeared, welcomed us kindly and ordered that punch be served. After two in the afternoon the General arrived mounted on a gray horse, and unaccompanied by a servant. He dismounted, shook our hands and cracked his whip; the horse went alone to the stable. After a brief conversation he retired to change his clothes, and we went to inspect the interior of the house.

"One enters into a hall which divides the house into two parts and ends on the piazza extending through the whole length of the rear of the house. This hall is painted white and clean; the floor is covered with a beautiful rug; the walls are decorated with engravings by Claude Lorraine. A kind of a crystal lantern contains a true, large key of the Bastille. This relic of despotism was presented to the General by Marquis de Lafayette. Underneath it is a picture representing the destruction of that prison. On the other side, on the piazza, is also a model of this Bastille, nearly two feet high, its interior and exterior reproduced exactly in all its details; it is made of stone taken from the wall of the Bastille; it is a pity that the children ruined it somewhat. To the left of the hall we enter into the parlor; here we see a portrait of Gen. Washington at the time when he was in the service of the British, in a blue uniform, crimson vest and breeches, adorned with silver braid, and a small bonnet of the shape of a mushroom on his head. The painter represented him on the march, and in order that everybody might know the fact he placed a paper in the pocket of the vest with the inscription: 'March order ;' he has a gun and a violet scarf across his shoulders. The other picture represents Mrs. Washington in a blue gown with a rigged up coiffure one inch high, with both ears uncovered; she holds a flower in her hand. This picture, never a good one, is much damaged today. There is also a picture of the family of Marquis Lafayette in American uniform; he is presenting to his seated wife his four year old son; two daughters, both of nearly the same stature, complete the group. The picture is well composed and painted, but the paint had peeled off in many places. There are also pictures of the son and daughter of Mrs. Washington by her first husband; the pictures of the General and his wife done in pastel; one of young Custis, her grandson; one of young Lafayette and of the divine Miss Custis who is represented with 


\section{POLAND AND THE AMERICAN REVOLUTIONARY WAR}

her hair blown about by a storm; also an allegorical picture in enamel in honor of the General and two pictures ingeniously embroidered with a needle.

"From this room we passed into another large one which the General added recently to his house. There is in it a fireplace of white marble with a very beautiful bas-relief. The pictures on the walls represent the cascades of the Potomac and other beautiful American landscapes, and there are also engravings of the American Revolutionary scenes by Trumbull. In the next room there are engravings representing seaports and storms, and a very beautiful harpsichord of Miss Custis. On the other side of the hall are the dining room, the bedroom of the General and Mrs. Washington and a library. The upper floor contains the rooms of Miss Custis, of her brother, and guest-rooms, all very clean and furnished completely.

"On the other side of the house, opposite the front, is a gallery supported by eight pillars; as beautiful a sight, as one can only imagine, may be observed from it. The Potomac rolling its waves majestically can be seen for a distance of four or five miles; the boats going up and down continuously move before the eyes. A beautiful tract of verdant land extends to a declivity and thence to the steep bank of the river; dense woods grow beneath it, which, however, do not hide the view. Many-colored birds flew among the trees. The gallery is the place where the General and his family and guests are wont to sit in the evenings to enjoy the most beautiful view. I enjoyed it myself most immensely. The situation of Mount Vernon from this point resembles very much that of Pulawy; ${ }^{29)}$ the river with its banks, the hill with the house, the thicket of the wood - everything increased this sweet illusion, except the house, which is longer and broader.

“About three o'clock a carriage drawn by two horses, accompanied by a man on horseback, stopped before the house. A young lady of the mast perfect beauty and another who was not at all beautiful, descended. It was Miss Custis, the granddaughter of Mrs. Washington; she had a face and stature rarely duplicated by nature and such as only painters create in their vivid imagination. One could not look at her without ecstasy. Her sweetness and goodness equal her beauty; she also possesses talents very rare in America; she is an accomplished musician and singer, besides this she draws and embroiders.

"After dinner we sat on the gallery to read the newspapers. The General conducted me through his garden; there were all kinds of vegetables and fruits known in Poland, but larger and more beautiful. The cherries are not so good as ours, and even those are eaten up by birds and negroes before they ripen. Niemcewicz.

29) A town in Poland, the seat of the Princes Czartoryski, friends of 


\section{JULIAN URSYN NIEMCEWICZ IN AMERICA}

Plums are very scarce; this fruit does not thrive in America, but instead, apples and pears, peaches, appricots, and almonds are very plentiful and of the best grade. Lilies, roses, carnations and other flowers, unknown to us, adorn this garden. The yard is planted with various trees, and their light or dark greenness and the various colors of flowers agreeably allure the eye. Two mighty chestnut-trees stand close to the house; they were planted by the General himself thirty years ago. Briefly, the house, the garden, the whole plantation and everything prove that a man born with a natural taste may design beauty without having seen its model. The General has never left America, but everybody who has seen his house and garden would say that he had copied the best models in England.

"In the evening we saw the cattle returning home. At the head went a magnificent bull imported from England. Marquis Lafayette had sent the General two stallions, one from Malta, another from Spain, and several mares. The donkeys are beautiful and large. The General had about fifty mules; these hybrids are very useful for heavy work.

"June 3rd. The following day, Sunday, the General spent the entire morning in writing letters. That day is always reserved for this occupation. I went out with Mr. Law. He showed me a hill covered with old chestnut-trees, oaks, weeping willows, cedars and cypresses. It was a cemetery.

“About one o'clock came Mrs. Law with her small daughter, and later there arrived a neighbor with his wife, a fat and redhaired woman whose enormous body was girded by a ribbon with a buckle of Bohemian glass. In the evening there was no music, not even a game of chess. It was Sunday, a day when even the slightest amusement is forbidden in America. At nine everybody retired."

On June 4-th Niemcewicz visited Washington's mill, his distillery producing 12,000 gallons of whiskey yearly, and his whole plantation which he describes very minutely in his diary. He learned accurately how rich Washington was and how large is his estate. He also commends his host for his kind treatment of negroes.

"June 5th. This morning Gen. Washington was so kind that he himself rode with us on horseback to show us another of his farms. He also showed us a plough of his invention: in the middle of the axle is a hollow cylinder with holes and full of corn; when the plough moves the cylinder revolves and the grain falls out in the furrow made by the plough-share; a small shovel placed behind covers the grain with earth.

"Many times have I heard Gen. Washington criticized for his taciturnity and reserve. It is true that he talks little, but, on the other hand, he does not avoid conversation, especially when the subject is interesting. 


\section{POLAND AND THE AMERICAN REVOLUTIONARY WAR}

"At the table, after the departure of the ladies, or in the evenings, when sitting on the piazza, he often spent hours talking with me."

Probably to those evening conversations refers that beautiful Polish poem of Niemcewicz commemorating the incident of Washington weeping over the sad fate of Poland:

"I still recall the day-so dear to me

When Washington's abode I came to see;

A man whose daring and whose spirit brave

To half the new world sacred freedom gave.

His name all hearts with gratitude doth fill,

His visage in my memory lingers still;

His figure's tall and stately, his hair gray,

His speech the ancient Roman doth betray.

Simplicity and grandeur and a stately grace

Are mirrored in his grave though kindly face.

Oft have I at Mt. Vernon listened to

His wise discourse, in silent awe and true!

He questioned me.-And when I told him how

We suffered from our foes, that Poland now

Lay prostrate and exhausted and quite weak,

A tear-drop trickled down the old man's cheek.

O tear! Thou patent token of our woes,

Could I but in a crystal thee inclose

Bright souvenir, thou wouldst attest withal

That once a great man wept o'er Poland's fall."'30)

Indeed, it was the most precious American tribute laid on the grave of Poland!

Though Niemcewicz had said on a previous occasion that Washington avoided all political discussion, and did not ask him anything connected with the fate of Poland, he evidently was not so strictly reserved at his home during a conversation with a friend.

"Agriculture was the beloved subject of Washington. With kindness and sweetness, however, he replied to my questions concerning the American Revolution, the army and other matters. His memory is remarkable. Once he enumerated for me all the lakes, rivers and creeks which flow in the United States and told me how the country could be connected by waterways from Portland, Me., to the Mississippi River.

30) It is an excerpt from Niemcewicz's Letter to General Kniaziewicz (Paris, 1834), translated by the Rev. J. P. Wachowski of Toledo, 0. 


\section{JULIAN URSYN NIEMCEWICZ IN AMERICA}

"Washington may have his faults because he is human, but, in the main, he is a great man, without blemish or selfishness; his virtues equal his services to his country. He exhibited bravery and exceptional knowledge of military art in battles, steadfastness and patience in adversity, modesty and disinterestedness at all times. He served without pay during the whole war, and he declined to accept any reward at the time of the greatest enthusiasm of grateful countrymen. He has shown that he was not eager for glory or power; for being in the position to remain for life at the head of a government and in supreme authority, he voluntarily abdicated the office of President. Exitus acta probat is the inscription which he most appropriately placed under his coat of arms.

"Since his retirement from public affairs and his return to his own fire-side he pursues a quiet and regular life. He rises at five in the morning, writes or reads till seven. At this hour the family and the guests, gentlemen and ladies, have to be in the dining room. His breakfast consists of tea and corn-waffles which he spreads with hot butter and honey. Immediately after breakfast he rides on horseback to see the work in the fields; often he himself works with an axe; sometimes he holds a 'war conference' in the field on horseback with Mr. Anderson, superintendent of his plantation; he returns after two, changes his clothes, and goes to dinner. After dinner he likes to talk with his friends, drinking a few glasses of Madeira wine. $\mathrm{He}$ reads diligently the newspapers of which he receives about a dozen different kinds. If there are any urgent letters to answer he answers them and returns to the conversation and company; at nine he retires.

"Mrs. Washington is a greatly respected and sensible woman; she unites sweetness with kindness; like every aged person she likes to talk about the past. She told me that she remembered pretty well when there was only one carriage in the whole of Virginia and when the ladies invited to a dance arrived on horseback. All the trade of the province consisted of little tobacco exported to England; the English correspondents did not fail to send their American friends one or two pounds of tea which was appreciated as a valuable present.

"I was considered at this respectable home and attended to, indeed, as a member of the family. I will cite only one fact which may seem trifling, but which gives a good idea of the persons and customs of the land. Not expecting to stay at Mount Vernon longer than two or three days, I took only three shirts with me; I do not know how they knew it, but every morning a negro came to me with compliments from Mrs. Washington and inquired whether I have any linen to be washed. Next day he brought me back the laundered linen."

Further entries in the diary of Niemcewicz from his stay at Mount Vernon are less important, though no less interesting. 


\section{POLAND AND THE AMERICAN REVOLUTIONARY WAR}

The poet spent the days in walking, fishing, conversing with Washington and with other members of the family, or playing chess with Mrs. Washington. On June 9th he notes: "Mrs. Washington gave me a China cup with her initials and the names of all the States belonging to the Union. The beautiful Miss Custis also made me a present in the form of a cipher decorated with flowers and executed very nicely in colors." All these presents he deposited afterwards in the private museum of the Czartoryski family at Pulawy, in Poland.

He left the hospitable home of Washington on June 14th. "Rising early I walked for the last time around the green woods of Mount Vernon, glanced at the wide view, at the clear and majestic waters of the Potomac, and at six in the morning, with silence more expressive of my gratitude than words for the hospitality and my sorrow on leaving their home, I bade farewell to the dear General, to his worthy wife, to the beautiful and kind Miss Custis.

"In the company of Mr. and Mrs. Law and their daughter we returned through Alexandria to Georgetown and spent the hot day with Mrs. Peters, the sister of Mrs. Law. I was received there most hospitably, as if I had been a member of their family.

"Next day I wrote to General Washington thanking him for the kind reception I had received in his home. He soon answered me."

"The satisfaction"-wrote Washington-"which our family had from the sweetness of your company in this solitude may only be compared with the sorrow which we felt on your departure and with our wishes that if you ever again visit this part of the United States you will not pass by the shadows of Mount Vernon without enjoying their coolness."

Assuring him of his sympathy for Poland, ${ }^{31)}$ he added:

"Your flattering words for me excite all my feelings. Sending you the best wishes of Mrs. Washington and Miss Custis, I do not forget to add mine (though I am convinced that from such a feeling heart as yours nothing can erase the memory of those misfortunes which befell your country) that you may experience in ours much kindness and attention which would bring relief to your griefs." 32 )

“Alas!" - writes Niemcewicz. "I did not avail myself of the kind invitation of this worthy man. I lived in another part of the country. A year and a half later Washington died..."

31) This paragraph of the Washington's letter is on p. p. 12-13.

32) J. U. Niemcewicz's Pism Różnych vol. I, p. 317. 


\section{JULIAN URSYN NIEMCEWICZ IN AMERICA}

4.

Niemcewicz visits the northern States and settles in Elizabeth. His marriage to Mrs. Kean.-His first voyage to Poland. - He publishes one of the first existing biographies of Washington.-His return to America and departure forever.

Having borrowed two hundred dollars from Thomas Jefferson Niemcewicz set out to visit the northern States. His tour was nearly the same as that of Wengierski. ${ }^{33)}$

"During my stay with Kosciuszko in London I learned to know the famous American painter Mr. Trumbull who painted many pictures of the American Revolutionary War. He gave me a letter to his brother who was Governor of Connecticut. ${ }^{34)}$ In passing through the capital city of that State, I stopped and felt it my duty to visit him; I entered his house, but found only his mother, wife and sister. One of them was reading aloud, the other two women were sewing. 'We are sorry,' said the wife, after reading the letter from her brother-in-law, 'my husband is not at home; he is out in the field mowing, but will be back at three. Be so kind and come to dine with us at that hour.' I came; soon also the Governor arrived in a small carriage with a scythe protruding from the rear end of his vehicle. After changing his clothes he came in and greeted me kindly. We sat down to dinner; it consisted of blackfish, roast mutton, apple pie and excellent Madeira and Constance wines. Then we talked about agriculture and business, about the prices of grain and of other commodities. Soon after dinner he said: 'Excuse me, I must leave you; I have to finish mowing to-day; I have hired men and must watch and help them.'

"This visit taught me the meaning of simplicity of customs and sensible equality which prevail in this free country.

"The public diligence to Boston would pass through here within a few days. Not willing to lose so much time, I had to hire a private carriage to catch the diligence at Providence. A well dressed citizen agreed to bring me there for a price.

"On our way I expressed my astonishment that a Governor himself does common work. 'You must be a European,' he said. 'How could he live if he did not work. Our fortunes are scattered, we have no negroes, and hired help is expensive; everybody has something, but not much. Though our Governor does his own mowing, we respect him more than you do your kings because he does not want to nor can he give a stupid order.'

“' 'And your wives,' I asked, 'what are they doing?'

33) Chapter 4 is based mainly on excerpts from Niemcewicz's Pamietniki Czasów Moich, written in his old age.

34) Jonathan Trumbull, (1740-1809), Governor of Connecticut from 1797 until his death. 


\section{POLAND AND THE AMERICAN REVOLUTIONARY WAR}

“" 'When they finish their household duties,' he said, 'they read the Bible, and while reading they sometimes fall asleep; but they always believe.'

"I was surprised at this curious answer, but though religion is held in great respect in America, there are too many people who do not take it seriously.

"I spent a few days in Boston. Nearby is a small town called Cambridge. I was pleased to find in the library there the magnificent and many volumed edition of Bibliotheca Fratrum Polonorum, edited and published by the Polish Brethren." 35 )

On his way from Boston to Albany Niemcewicz had occasion to see a colony of the strange sect of Shaking Quakers. "At Albany I visited my old acquaintance, Mrs. Church, the daughter of General Schuyler, with whom I became acquainted at Paris in 1787. There are left in Albany many traces of the Dutch who were the first settlers there."

After a stop at West Point where he visited the fortifications and the famous Kosciuszko Garden, he returned to New York by boat. At West Point, he says, there "were still visible the traces of garden-beds which Kosciuszko had planted and cultivated."

"I arrived in New York at the time when the yellow fever epidemic was at its height. Not long ago the city was populous, its streets busy; now it was sad and deserted. Everybody who could afford it fled to the country; the only people one could see in the streets were negroes carrying yellow and emaciated bodies on their shoulders. The fear of the strongly contagious disease caused kinsmen and friends to desert even their most beloved. The few pedestrians avoided one another, not daring to exchange greetings or start a conversation. I lost at that time my good friend Dr. Scandola, a highly learned and amiable man. Having found nobody of my acquaintances in New York and not willing to expose myself to the sickness, I spent only one night in the city and left by boat for Elizabethtown.

"Having visited the northern, central and part of the southern States, and having spent nearly all the money borrowed from Mr. Jefferson, I had to look for a place where I could settle. I chose Elizabethtown where during my earlier sojourn I came to know many inhabitants. That town was then the refuge of many French families from Santo Domingo, Martinique, Guadaloupe and from other islands of the West Indies, from which places they fled before the cruelty of the negroes. There lived also Lord Bolingbroke under the name of Bolassis. He eloped with the niece of the late Grand Master of the Order of Malta. Their presence gave to the town a European atmosphere. Among the native inhabitants the

35) The Polish Brethren were the forerunners of the Unitarians. The religious writings of their leaders were published under the general title Bibliotheca Fratrum Polonorum in the 17-th century. 


\section{JULIAN URASYN NIEMCEWICZ IN AMERICA}

most prominent was the Ricketts family; Mrs. Ricketts, nee Livingston, was the sister of my future wife; there were also the Daytons, the Williamsons, the Ogdens and other families.

"I rented a small room from Mr. Rivers, a tailor, ate with him and his helpers, bought fire-wood and sawed it myself." When his finances were in the most desperate condition he received a large sum of money from his friend in Poland, Prince Adam C. Czartoryski, ${ }^{36)}$ which enabled him to pay his debt to Mr. Jefferson and insured his livelihood for some time.

"Reading, writing and occasional hunting were my occupation. I was then in the flower of my life, forty years of age. I made many new acquaintances, among whom was also Mrs. Kean, the widow of a friend of Kosciuszko, who showed me much sympathy. Her interest in me encouraged me to visit her often.

“In 1799, Gen. Washington's death caused sorrow throughout the United States. Mourning services were held in all larger American cities. I was present at such services in New York. Gouverneur Morris, one of the most eminent citizens of that city, idelivered a beautiful funeral speech. ${ }^{37)}$ Freemasons carried a casket in a pompous procession. All the militia of the city escorted it and fired three salutes. But real merit has always its calumniators. How many times did I hear people saying that Washington was a coward and Franklin a fool.

"Among the prominent persons whom I had occasion to meet in the United States was also Gen. Miranda. ${ }^{38)}$ Having entered the French service at the outbreak of the revolution, he commanded a division; but when the Convention became a mad executioner, he left France, returned to his country and settled in Caracas. Among the American volunteers who took part in his revolution in Venezuela was a Pole from Dantzig whose name I have forgotten. Miranda escaped later to New York where I saw him often. He was of enormous stature, a fluent and fiery speaker.

"Another political exile was General Moreau, who later died at Dresden. ${ }^{39)}$ Banished from France by Napoleon, he lived with his wife and with an aid-de-camp in a country house near Philadelphia where I visited him. He was also in New York and he stayed at our home when passing Elizabethtown.

36) Prince Adam Casimir Czartoryski, (1734-1823), Polish statesman, usually distinguished from his son, Prince Adam George Czartoryski, $(1770-1861)$, also a Polish statesman, by his official title General of Podolia. Both played a very prominent role in the history of Poland in the 18-th and 19-th centuries. Niemcewicz was tutor of the younger Czartoryski.

37) Gouverneur Morris, (1752-1816), jurist and statesman.

38) Francisco Miranda, (1756-1816), Venezuelian patriot. In 1806 he outfitted an expedition in the United States to liberate the Spanish province Caracas, which now constitutes the republic of Venezuela, but was unsuccessful.

39) Gen. Jean Victor Marie Moreau, (1763-1813). 


\section{POLAND AND THE AMERICAN REVOLUTIONARY WAR}

"On Staten Island lived Du Pont de Nemours, ${ }^{40)}$ an ingenious man, and full of imagination, but very frivolous; he was the author of the Philosophy of Nature, in which he maintained that he is able to understand the language of all animals. He returned to France after the restoration of the Bourbons, but when Napoleon returned from his exile in Elba, he again fled to America to his son who had there a gun-powder mill. This Du Pont de Nemours was tutor of Prince Adam Czartoryski for some time, but his innate instability drove him back to France. Once Du Pont de Nemours and his son were guests in my home.

"I had also the honor to become acquainted with the successor to Washington, John Adams, with Thomas Jefferson and with Gen. Hamilton. Jefferson was a more learned man than the others; being an ardent republican, he encouraged the spread of culture. It was he who during his presidency founded the first public library at Washington. Gen. Hamilton was, without doubt, a genius not only as a lawyer, but also as a financier. He was the first to introduce the system of amortisation of public debts which Pitt later made use of in England.

"Having said so much about others, as far as I remember, I will now say a few words about myself.

"I boarded for two years with Mr. Rivers, the tailor. During that time my relations with my future wife, Mrs. Kean, nee Livingston, were getting more intimate. ${ }^{41)}$ Since I was only an exile, I did not dare to ask her for her hand lest she think that it were not her personal qualities, but her large fortune, that attracted a poor man to her. But once during our conversation she gave me her hand, saying: 'If you want it, this hand is yours.' I took her by the hand and kissed it. Mrs. Kean belonged to the foremost families in New York. She was tall, blond, with blue eyes, light complexion, more lively and comely, than beautiful; she was wellread and had a very good memory, was pleasing in conversation and witty in her answers. Nervous attacks made her excited at times, but she was a woman of uncommon intellect and of an excellent heart. She had a son, Peter Kean, ten years of age, whose teacher I became after our marriage. ${ }^{42)}$

40) Pierre Samuel Du Pont de Nemours, (1739-1817), French political economist and statesman, founder of the American family of that name.

41) Susan Kean, daughter of Peter Van Brugh Livingston, son of Philip Livingston, Second Lord of the Manor of Livingston, N. Y., and Mary, nee Alexander, daughter of James Alexander, Surveyor General of New York and New Jersey. Her first husband, John Kean of South Carolina, was a delegate to the Continental Congress in 1785-87, and cashier of the first bank of the United States at Philadelphia. He died in 1796 .

42) Peter Philip James Kean, born in Elizabeth, in 1788; died at New Lebanon, N. Y., in 1828; son of John and Susan (Livingston) Kean. $\mathrm{He}$ graduated from Princeton University in 1807 . He was prominent in the military affairs of the State of New Jersey, and in 1824, when the Marquis de Lafayette revisited the United States, Gov. Williamson ap- 


\section{JULIAN URISYN NIEMCEWICZ IN AMERICA}

"But this marriage took place not earlier than in 1800. I did not press it at all; she also hesitated many times, discouraged by the remarks of her brother and sister, Mrs. Ricketts, who advised her not to unite with an unknown foreigner. Time passed; I decided already to move to the new city of Washington to open there a book-shop when the frightened bride sent me a letter declaring that she is ready to fulfill her promise and to fix the date of the wedding. I answered that I do not want to force her and that I am freeing her from her promise, but if she thinks she will be happy with me, I shall not marry her unless it will be stipulated in our marriage contract that I give up entirely all rights to her fortune. My disinterestedness astonished her brother and other relatives; they ceased their opposition and began to urge our marriage, which took place in June, 1800.

"While we still waited for our wedding my wife who was living with Mr. and Mrs. William Dayton, ${ }^{43)}$ bought from Dr. Clark $^{44)}$ a small house with a garden and meadow and also eighteen acres of land beyond the town, partly arable, partly salt-marsh. The house consisted of two small rooms on the first floor, two on the upper one, with a small study, kitchen, and a garret; there was also a stable for a team of horses and a cow. Because of the confiscatory acts of the Russian government in respect to my property in Poland, I was able to bring to our common home an estate worth scarcely a hundred Polish zlotys. ${ }^{45)}$

"On the day of my wedding and before the ceremony of the marriage contract by which I renounced all rights to the estate of my wife, I went to a nearby creek to take a bath. I brought my linen and suit of clothes from my room at the tailor's house and dressed in the stable. Only a handful of friends were present at the ceremony. An Episcopalian clergyman Hobart, who later became Bishop, performed the ceremony. ${ }^{46)}$ At the end of this modest wedding tea and punch of arrack were served; punch is always made of arrack here at the weddings.

pointed Major Kean on the reception committee to welcome him to the State; a post to which his fluent knowledge of French, imparted to him by Niemcewicz, proved an added qualification. At the time of his death, Mr. Kean was Colonel of the Fourth Regiment of the State of New Jersey. He married Sarah Sabina Morris, daughter of Gen. Jacob Morris, in 1813.

43) William Dayton, son of Gen. Elias Dayton, mentioned as Captain and member of the City Council in E. F. Hatfield's History of Elizabeth, N.J., N. Y., 1868 , p. p. 550 and 653 .

44) Dr. Ábraham Clark, son of a Revolutionary patriot, mentioned as librarian of Library Association in Elizabeth in 1796 in N. Mirray's Notes Historical and Biographical concerning Elizabethtown, Elizabethtown, N. J., 1844 , p. 89.

45) The Russian government confiscated the estate of Niemcewicz in Poland and prohibited his family from sending him any aid for his part in the Insurrection of Kosciuszko in 1794.

46) John Henry Hobart, D. D., (1775-1830), successively pastor at New Brunswick, Hempstead and Trinity Church in New York; chosen Bishop of New York, in 1816; author of numerous theological works. 


\section{POLAND AND THE AMERICAN REVOLUTIONARY WAR}

"Next day I went to my fat landlady, Mrs. Rivers. I presented her with a silver spoon, took my belongings and moved to my wife.

"It will not be out of place to narrate my manner of living in these new circumstances. It was suitable to the custom of this land where everybody has some occupation. My education in the Polish Military Academy and my long stay with the family of Prince Adam Czartoryski, the General of Podolia and Commander of Lithuanian troops, gave me only some knowledge of the military art and a little of literature; I always felt an innate inclination to the latter. It was impossible for me to get a commission in the army of the land, which had only three or four thousand regular soldiers and eight hundred thousand militia. Unfortunately, I did not know any other profession, but could not remain idle. So I decided to be a gardener and a farmer on the small property of my wife.

"In the first year I dug my garden and manured it, only seldom using hired help; I brought sweet potatoes from Carolina and provided best seeds for sowing and best billets to ingraft the fruit-trees, especially peaches, apricots and nectarines. Among the vegetables I planted, besides the usual kinds, also eggplant, and poor man's beans; it is a kind of small beans which is suitable to eat a week after planting.

"On the farm beyond the town I raised corn, potatoes and pumpkins, and gathered salt-hay. I also planted trees of the kind called Liliodendrum Tulipiferum, bearing sweet-scented tulip flowers, on the side of the farm bordering on the road. In my garden, along the roadside, I planted large blacknut-trees, hickory-trees and others. On my departure in 1807 everything in the garden and on the farm was already in a fine condition of growth.

"The imported seeds of Persian melons produced the best crop; watermelons weighed to forty pounds, pumpkins to seventy. After my return to Poland I planted the same seeds on my property there, Ursynow, and also a kind of large cabbage, called drumhead. But because of colder climate the same seeds produced much smaller fruits, though larger than usual in Poland.

"My usual order of the day was: Having risen in the morning I said prayers, then took a basket and went to the market to buy meat or fish. Our table was frugal as everywhere in America. Plenty and splendor are there exclusively for the guests; especially after New Year when all the prominent inhabitants of the town give receptions to all others by turns. The dessert consists of an enormous quantity of confectionery. I remember how I helped my wife to make jellies for a few evenings each year.

"On returning home I worked in the garden for an hour; then followed breakfast consisting of tea and a piece of fried sea-fish. After breakfast I taught my stepson, Peter Kean, Latin, French, geography, etc. Peter was not a handsome, but a talented boy, and of a very good heart. 


\section{JULIAN URSYN NIEMCEWICZ IN AMERICA}

"After lessons I worked again in the garden, or in the field beyond the town, if I had hired help. But that is expensive in America. A hired man is paid at least eight Polish zlotys (about one dollar) a day; besides, he gets breakfast, dinner, whisky and tea. Abraham Mann usually helped me in my work."

To those happy and peaceful days refer the lines which the poet wrote many years later:

"How oft has Aurora, from his soft couch of blue,

Found me cutting fresh grass, all so pearly with dew;

Or engrafting a shoot on the thriving young tree,

While nature was smiling in beauty and glee.

$\mathrm{O}$ delightful employment!-with pleasure how rife

Are the exquisite scenes of a pastoral life...

"So pure were the joys and so peaceful the life

That I shared with my lovely and beautiful wife,

I might have been happy, could man but forget

When his country with deadliest foes is beset.

But too oft the sad thoughts would convey me away

In the stillness of midnight, the bustle of day,

Thro' the foam-crested waves of dark rolling sea,

To thee, distressed Poland-once peaceful and free!" ${ }_{47)}$

"Now I will say a few words about the daily life of an American town. Everybody is engaged in his business during the day. Sometimes there appears in the house a negro boy or girl, yet able to talk only very little, with a card pinned to its dress; more important work does not permit the use of grown-up servants for running errands. The lady of the house unpins the card and reads it. It is an invitation to tea in the evening. In the evening the work ceases and friendly gatherings begin. After the ladies are assembled, the men come, wash and dress; tea, bread, toasts and smoked beef cut in slices are served; the men talk about agriculture, business and politics; the ladies complain of the obstinacy of their negresses, and so on. After tea confectionery is served, also home made jellies, Malaga wine, and so the day ends.

"Our neighbor was Mr. Horace Dayton who received his house with the garden as a dowry when he married his cousin. ${ }^{48)}$ The family of the girl opposed the marriage and as the abduction of a female is a felony according to law, the lovers decided that the girl would abduct the bridegroom. In fact, she came on horseback to his house at night; he jumped on the horse behind her, and both came to the nearest clergyman who performed the marriage. In this way he avoided the penalty because she, not he, was the abductor.

47) Paul Soboleski, Poets and Poetry of Poland, p. 167.

48) Horatio R. Dayton's name appears on the Constitution of the Library Ass. of Elizabeth of 1792. (E. F. Hatfield, History of Elizabeth, N. 7., p. 562). 


\section{POLAND AND THE AMERICAN REVOLUTIONARY WAR}

"In the Summer of 1802, I received unexpectedly a letter from my old friend, Thaddeus Matuszewicz, ${ }^{49)}$ informing me of the death of my father and that the family affairs demand my presence, if only for a short time. The Russian Tsar Alexander was now dead, and all the edicts against me lost their force. My wife allowed me to depart with difficulty. I sailed in July and after fifty days reached London. After a week's stay there I arrived at Warsaw by way of Hamburg and Berlin, in the first days of October."

Niemcewicz was now able to see his relatives and old friends. He spent the Winter of 1802-3 with the Princes Czartoryski at their country seat, Pulawy, and in 1803 he published in Warsaw two volumes of his Polish poetry and prose.They contained, among other works, a biography of Washington, Krótka Wiadomość o życiu i Sprawach Generala Washington. Niemcewicz's work appeared three years after the first edition of the valueless Life of Washington by the Rev. Mason Weems; it anteceded by a year the first American biography of Washington, which deserves attention, the five-volumed work of identical title by John Marshall. Though not complete in biographical particulars, its chief and lasting value are Niemcewicz's personal recollections of Washington and of his stay at Mount Vernon. ${ }^{50)}$

Having sold his estate in Poland, the poet returned to America in September of 1804, landing at Norfolk, Va.

"Scarcely had I put my foot on land when a crowd of newspaper men surrounded me asking for news from Europe. After spending two days at Norfolk, I took the next ship sailing by way of Baltimore to Philadelphia.

"At Philadelphia I found my brother-in-law, Mr. Ricketts with wife and daughter. I brought them presents from Paris and remained with them two days. At New Brunswick I learned of Gen. White's death; he left a widow and an only daughter. Next day, setting out on my way in the morning, I arrived at Elizabethtown at two o'clock in the afternoon.

"Though I have been absent for two years, it seemed to me as I was driving through the town that scarcely a day had passed since I left it, for all the inhabitants were occupied with the same businesses; Mr. Mann who on the day of my departure planed shingles before the house of Billy Dayton, was again sitting at the same place and doing the same thing.

"I learned that my wife rented her small house to some party and bought a larger one for us. I ran there as quickly as possible, ordering to bring my trunk after me. Our meeting was

49) Thaddeus Matuszewicz, (1765-1819), Polish patriot and writer, Minister of Treasury of the Grand Duchy of Warsaw and later of the Kingdom of Poland, created by the Congress of Vienna.

50) The Encyclopaedia Britannica (vol. XXVIII, p. 3345) gives the date of the first edition of Weems's biography as 1800. Marshall's work appeared in 1804-1807. 


\section{JULIAN URSYN NIEMCEWICZ IN AMERICA}

joyful. I found my wife busy with preparing her son, Peter Kean, for Princeton College. How many questions, how many embraces did we exchange! My baggage was brought in; there were only few of my own things in the trunk; it was full of presents for my wife, stepson, friends and for the decoration of our house. I brought a beautiful furred cloak of Turkish material for my wife; it had golden flowers on a green background; also a beautiful shawl, a necklace of mosaic, a clock and candlesticks of bronze. My stepson received a Turkish sword in a beautiful scabbard, given to me for him by my former Commandant, ${ }^{51)}$ and a large hat; my good boy immediately put them on and began to parade on the street surrounded by boys. I brought also portraits of my friends in miniatures and oil-paintings, views of Warsaw, of Pulawy, of my home at Skoki, Poland, etc. All these things decorate now the house of my stepson which he bought after my departure from America and which he called Ursino in my honor. ${ }^{52)}$

"The new house of my wife was larger and more comfortable than the old cage. I had a separate room for writing and reading. I continued to write a long planned and recently started poem on the four seasons of human life. I finished it later at Paris.

"In Winter we visited the brother of my wife, Philip Livingston, who, as long as health, age and strength served him, was one of the most eminent citizens of the United States and president of a bank at New York. We found him in a different state of health, suffering much from gout.

"In the Spring of $1805 \mathrm{my}$ wife wished to visit her relatives who lived mostly near the West River and the Hudson. We visited first her niece, Mrs. Rutgers, nee Bayard. There, I do not know from what cause, I suffered an attack of sickness, similar to yellow fever. In the course of this malady I had such intolerable headaches that I would spring out of my bed and roll on the floor. To cure me, Dr. Williamson ${ }^{53}$ ) had recourse to a strong poison, arsenic, which he gave me in a very small dose; in two weeks the fever abated. We again set out on our way, this time by boat to West Point, famous in the American Revolutionary War. The purpose of our voyage was to visit Mr. and Mrs. Williams. Colonel Williams ${ }^{54)}$ was commandant of this fortress, which seemed fortified more by nature than by art. Mrs. Williams was an Englishwoman by birth, nee Alexander; they were both kind and edu-

51) Prince Adam Casimir Czartoryski, who was Commandant of the Polish Military Academy at Warsaw.

52) It was the "Liberty Hall," built by the uncle of Mrs. Kean, William Livingston, first Governor of the State of New Jersey. The estate is still in the possession of the Kean family and its name, Ursino, remains to this day. Hon. Hamilton Fish Kean, United States Senator, the present proprietor of Ursino, informed the author that the sword and many other relics of Niemcewicz are still preserved there.

53) Hugh Williamson, (1735-1819), educator, physician, author.

54) Jonathan Williams, (1750-1815), jurist, author, military officer; the first superintendent of the Military Academy at West Point. 


\section{POLAND AND THE AMERICAN REVOLUTIONARY WAR}

cated; their behavior gave evidence that they had visited Europe. The Colonel was a grand-nephew of the famous Benjamin Franklin. Their daughter was an excellent woman; she was a good painter and made for me a portrait of Franklin in miniature which I carry on my snuff-box to this day.

"During our stay with Mr. and Mrs. Williams we visited our acquaintances living along the North River. There is nothing more splendid than this river closed in by sky-high and steep rocks; it is so wide and deep that large three masted ships sail on it.

"In the company of Lord and Lady Bolingbroke, my neighbors from Elizabethtown, I made a trip to Niagara. I would reproach myself if, being in America, I had not seen this wonder of nature. Alas! the wilderness through which we had to pass was then pathless to such an extent that we haid to cut our way through the forests with axes.

"In Summer Lord Bolingbroke, who for some important reasons took refuge in America under the name of Mr. Bolassis, left for England together with his wife. It was a great loss to me; one does not meet persons of better manners, good education and social position every day in America.

"Having lived in America the time prescribed by law, I went to Colonel Aaron Ogden, one of the most prominent lawyers in Elizabethtown, ${ }^{55)}$ and asked him to help me to become a citizen. We left together for Newark, the capital of our county. There Mr. Ogden deposed under oath that I have lived in the United States as many years as provided for by law and I renounced my nobility and my subjection to the Russian Tsar; I then took an oath of fidelity to the laws of my new country. The magistrate issued to me immediately a sealed certificate of naturalization as a citizen of the United States. To show Mr. Ogden my gratitude, I gave him a sword with a Polish inscription: Long live the Constitution of the Third of May.

"In the late Fall of 1806 came the first news of Napoleon's war against Prussia and Russia" and then of the proclamation of the Grand Duchy of Warsaw.

"How eagerly I awaited the ships from Europe and the news pertaining to this war. My lost hopes began to revive. I was vexed by the desire to return to my old country as soon as possible to be of service to her. But it was hard for me to leave my affectionate wife. Being in poor health, not knowing any language beside the English, foreign to European customs, and, moreover, having a young and only son, she did not dare to go with me and feared to part with me. I used the mediatorship of Mr. Rutherfurd, her relative and one of the most prominent men in America. ${ }^{56)} \mathrm{He}$

55) Aaron Ogden, (1756-1839), Revolutionary officer, jurist, U. S. Senator and Governor of New Jersey.

56) Robert Rutherfurd, large landholder, living on his estate at Edgerton, on the Passaic River, known as Rutherfurd Park; he was a public- 


\section{JULIAN URSYN NIEMCEWICZ IN AMERICA}

persuaded my wife, and she, finally, admitted it herself, that it was my duty as a Pole by birth, to go to the aid of my country at this important time. She even promised to join me should Poland be restored.

"She only asked that before my departure I go to Philadelphia with her to visit our old friends; to this I agreed as I myself wanted to take leave of those who were so kind to me in my first days in America. We stopped in the house of Christine Biddle, the daughter of a friend of Mr. and Mrs. Williams. ${ }^{57)}$ I visited Dr. Rush, whose lecture I heard ten years ago, also Mr. and Mrs. Bingham, the richest inhabitants of Philadelphia ${ }^{58)}$ and $\mathrm{Mr}$. and Mrs. Patterson, whose father was most instrumental in my election to a membership of the American Philosophical Society in Philadelphia; and, at last, the families of Pemberton, Logan and Clarke, all good Quakers. Mr. Pemberton, then 84 years old, and his wife, of about the same age, were very friendly to me; they were the real types of original Quakers; rich, kind and amiable.

"After a week we left Philadelphia and returned home. Notified that my ship was ready for Bordeaux, we went to New York and there I spent a few days more with the relatives of my wife. I was afraid of our last farewell. Assured by my wife that she would join me soon, I ordered my baggage to be brought aboard, and after writing a letter to her, I went aboard myself. The ship was new, very good, well provisioned in poultry, sheep and hogs, Port and various other kinds of wine, so that we only seldom drank water during our voyage. The passengers were kind and numerous, the weather very fine; in short, this my fourth passage across the Atlantic was most agreeable."

It was Niemcewicz's lot never to see America nor his wife again. His further life was only loosely connected with this country. Having returned to Poland, he was soon absorbed in literary, political and social activity. After the outbreak of the Polish Revolution of 1830 , he was sent by the Revolutionary Government as Minister to England. He spent the rest of his life as an exile, working incessantly for Poland until his last days.

This patriotic activity did not allow him to return to his American home. But he kept up most cordial relations with Mrs. Niemcewicz through correspondence. In his memoirs of later years, ${ }^{59}$ ) he frequently mentions receiving letters from her or, in turn, sending some to her, sending her some present or receiving money from her; more than once he speaks of her with lively attachment. Often also he was visited in England and in France

spirited man and served in the Congress of 1793 ; married a sister of Lewis Morris, signer of the Declaration of Independence.

57) Biddle, a very prominent family of Philadelphia.

58) William Bingham, at that time one of the richest men in the United States; he was full of aristocratic notions.

59) Dziennik Pobytu Zagranica, Poznan, 1876. 


\section{POLAND AND THE AMERICAN REVOLUTIONARY WAR}

by Americans, who came to him voluntarily, or directed to him by Mrs. Niemcewicz. A curious episode connected with one of these visits he notes in London under date of September 26, 1832:

"Miss Douglas, an American and a friend of my wife, came from Paris with her brother to visit me. I took advantage of this occasion and wrote a letter to my wife. She invited me to a dinner. Miss Douglas is quite comely, rich, lively and loquacious; she is a friend of Poland and in the beginnings of our Revolution offered a hundred guineas to support our cause. Her brother suffers from religious exaltation to such a degree that his mind seems to be out of order. He always reads the Bible and believes that he communicates with God and from Him receives inspirations. He himself told me how a scoundrel Frenchman came to him asking him for a loan of four thousand franes; not knowing the man he declined; but opening the Bible he found the words: 'if anybody will ask you to lend him money do not turn away from him;' he ran out into the street and finding the man gave him four thousand franes never to see them again."

Of his relations with Mrs. Niemcewicz and her family in this period writes Prince Adam George Czartoryski, his biographer:

"Mrs. Niemcewicz preceded her husband to the grave by only a few years. Their correspondence was frequent and cordial and never broke off until her death. The steady uncertainty of the events, her old age and bad health, the difference of climate and customs, her ignorance of any other language beside the English, did not allow her to join her husband. But they informed each other in their letters of all particulars and circumstances of their lives, seperated by necessity. Mrs. Niemcewicz knowing the misfortunes of Poland and the bad situation of the Polish political emigrants, often sent financial help to her husband and in her last will provided for him a yearly income of six hundred dollars for life. Peter Kean, the son of Mrs. Niemcewicz, with whose education his step-father so willingly and affectionately busied himself in America, and who meanwhile reached maturity and became an heir, was always grateful and attached to Niemcewicz; he died before his mother, leaving children from an early marriage. The family named their estate Ursino and always respected the memory of Niemcewicz. When they happened to come to Europe they sought out his acquaintances and friends to tell them how proud they were of him. Not long ago a granddaughter of Mrs. Niemcewicz came to Paris and visited me at the request of his brother, Mr. Kean, the son of Niemcewicz's step-son, who is now the proprietor of Ursino." 60 )

When Polish soldiers after the Revolution of 1830-1 began to flock to America hoping to find here freedom and hospitality, Niemcewicz tried to help them by his letters to prominent Ameri-

60) Prince Adam George Czartoryski, Żywot J. U. Niemcewicza, p. 249. 


\section{JULIAN URSYN NIEMCEWICZ IN AMERICA}

cans, especially to Albert Gallatin, who was one of the most sincere friends of Poland at the time of her reverses.

Niemcewicz kept faith with the United States to his last breath, and during his labors for Poland as an exile in England and France he frequently longed for his adopted country. Under date of October 12,1831, he wrote in his diary: "O, were it not for my old age and the distance, how gladly would I seek refuge in the United States." 61 ) And to the Poles who were deported by Austria to America in 1834, he wrote:

"Why does my age and my strength, broken by so many misfortunes, not permit me to see America again, that country which gave me a hospitable asylum during ten years, whose citizen I have the consolation and honor to be, with which I am united by the dearest ties of memory and consanguinity! How happy should I be to end my miserable life amongst you. A field stone over my grave in yon free country would be more glorious to me than the most gorgeous mausoleum in the country of slaves." ${ }^{62}$ )

Touched by the sad fate of the Polish exiles then wandering through all the countries of the world, Niemcewicz lamented:

"Ye exiles, roaming through the world so helplessly and long,

When will your weary feet find rest, o broken-hearted throng!

The wild dove finds its hidden nest, the worm its native clod,

But Poland's son can only claim of earth a burial sod!"'63)

He also died as an exile, among a free, though foreign nation far from his beloved Poland and the United States, his not less beloved, though adopted country.

He breathed his last in Paris, in the summer of 1841. "It was on the first of June; and on the eighth of the month he was buried with military honors and with all the distinguishing rites of the church. The funeral service was performed by the Archbishop of Chalcidonia, with a large body of the clergy attending. A choir of fifty professors sang the Mass, and more than a thousand persons thronged in the procession,--persons of all nations, of all creeds, religious or political, of every rank among men, of every mind, from the prince to the peasant, that understood the true value of genius when helmed by virtue." 64 )

Among the mournful throng were also Americans and one of them, Mr. Gibbs, spoke at the open grave in the name of his countrymen.

"Gentlemen," he said, "the noble Polander to whom we pay the last tribute has the sympathy of all my fellow-countrymen; as to the American citizen, companion of Kosciuszko and to the friend of liberty, I outrun, I am sure, and express their wishes,

\footnotetext{
61) Dziennik Pobytu Zagranica.

62) Niles' Register, Feb. 7, 1835.

63) Paul Soboleski, Poets and Poetry of Poland, p. 174.

64) Jane Porter, Thaddeus of Warsaw, Notes, p. 535.
} 


\section{POLAND AND THE AMERICAN REVOLUTIONARY WAR}

when in their name and mine I pay to his memory due tribute of profound esteem. Firm in his principles, magnanimous and unconcerned for himself in the hopes of prosperity for the cause of mankind, his memory deserves the eulogies of good men of all countries. His name will be placed among those of my fellowcountrymen who are honored with the name of benefactors of mankind." 65)

On the news of his death, the American Philosophical Society adopted a resolution expressing a "profound grief at the death of their respected member" and announcing the wearing of the "usual mourning for thirty days" by all members.

65) Paul Soboleski, Poets and Poetry of Poland, p. 164. 
APPENDICES 


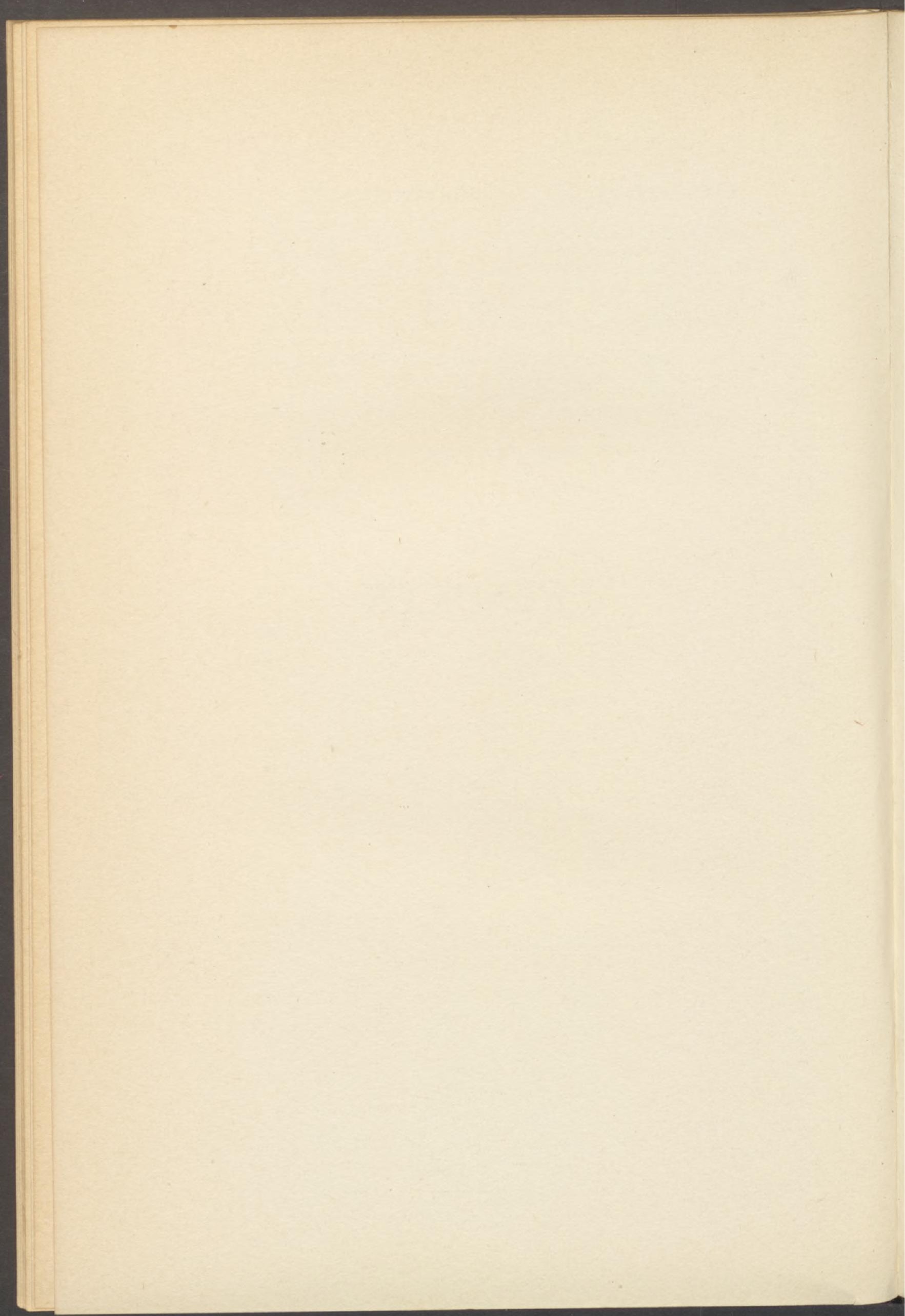




\section{A. WASHINGTONIANA IN POLAND}

(In connection with the National Historical Loan Exhibition in Washington, D. C., during the year of 1932, the Museum of the Princes Czartoryski at Cracow, Poland, loaned to the United States the following Washingtoniana, for the most part unknown in this country. Copies furnished to the author through the courtesy of the Polish Embassy at Washington).

I.

GEORGE WASHINGTON TO THADDEUS KOSCIUSZKO (MS. Bibl. Czart, Nr. 2786, p. 21-22)

Dear Sir. Mount Vernon $15^{\text {th }}$ Octr 1797.

Your favour - dated Elizabeth Town October - has been duly received. - I am sorry that the state of your health should e deprive me of the

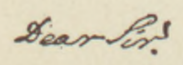

Mowaterawi: is odt ${ }^{2} 1797$

Tour fasoundated Eleya:

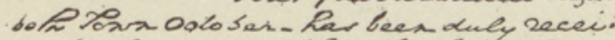
rex:- - as-romy hack thith ofyem risethe honed deprive nue ofta slea sure of bour comprany at thiv blave-

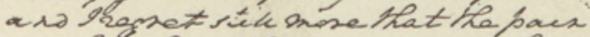

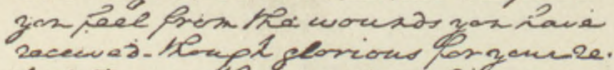
putation-es he ocearion ofit.

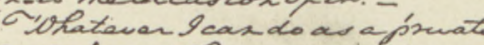

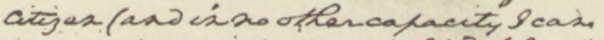

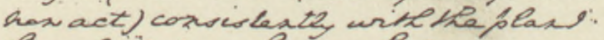
Lava laida dewa for my fiture gervera

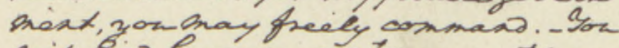
aill pisi lowesor, contranyar trinay Serozorivexpectation or asisher, that

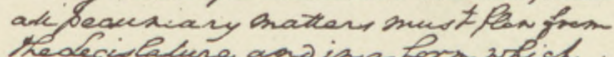

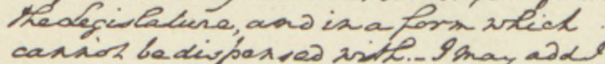

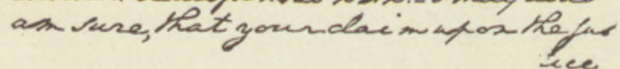

Fie teeciner of thi country ask neet with no delay, - roordo Isuppore thal the Efs of your certifieate wru keary in. sesims $x t$ - Zownsark and pervieeres. the anericar army are too del krax toraguise that terterony ofyourdrin. axathe Aooter offle troa Sury ailustein that yoin have receciver hothin ca dis.. chinge ofit.-orif any bart, to what $a$. movit. - nith he hiplerterlen, repar and eeplect, las. Eenenal Horcueurgtio Gown most obed.gugen' civaplinetros pleasure of your company at this place and I regret still more that the pain you feel from the wounds you have received--though glorious for your reputation-is the occasion of it.

Whatever I can do as a private Citizen (and in no other capacity I can now act) consistently with the plan I have laid for my future government, you may freely command. - You will find however, contrary as it may be to your expectation or wishes, that all pecuniary matters must flow from the Legislature, and in a form which cannot be dispensed with. - I may add I am sure, that your claim upon the justice of feelings of this country will meet with no delay; - Nor do I suppose that the loss of your certificate 


\section{POLAND AND THE AMERICAN REVOLUTIONARY WAR}

will be any impediment. - Your rank and services in the American Army are too well known to require that testimony of your claim; and the Books of the Treasury will show that you have received nothing in discharge of it, - or if any part, to what amount. - With the highest esteem, regard and respect,

\section{I am Dear Sir}

Your Most Obed ${ }^{t} \mathrm{H}^{\text {ble }}$ Serv $^{t}$

General Kosciuszko

Ge Washington

\section{II.}

GEORGE WASHINGTON TO MARQUIS LAFAYETTE

(MS. Bibl. Czart, Nr. 2786, p. 17-18)

My dear Marquis,

White-Plains, Aug. 19-78:9

This Letter will be delivered to you by Mons'r Laneville to whom, I have no doubt, you will show civility, as he appears to me to be a Gent'n of sense \& science. - I hope, however, he will come too late to afford you any aid - I say so, because I could wish he may find the work already done, of which, I have some hope from Gen'l Sullivan's last Letter.

I have lately received a horse for you from Col'o Bland, so exceedingly poor that he can scarce walk - I have put him into the care of my Servant and have ordered him to use his utmost exertions to get him in order for you, but it will be many months before he can be fit for any kind of service.

Adieu my dear Marquis. - May hap's and glory attend you - This is the sincere wish of your affect'e friend.

Ge Washington.

III.

\section{EXCERPTS FROM WASHINGTON'S LETTERS}

(MS. Bibl. Czart, Nr. 2786, p. 16)

...chase it, - nor shall I pronounce the price he has set upon it, high, or low; - The situation alone constitutes the value of it in my estimation, but my becoming the purchaser thereof, depends upon three things; two of which I have little expectation of his acceding to.......

First, the quantum of square.... at 15 Cents....

IV.

(MS. Bibl. Czart, Nr. 2786, p. 15)

....this subject, but am always

Dear Sir

Your Obed't and Affect'e Serv.

Ge Washington. 


\section{APPENDICES}

V.

THOMAS LAW TO HIS BROTHER

(MS. Bibl. Czart, Nr. 2786, p. 29-32)

Mount Vernon,

Dec. 15-th, 1799.

\section{Dear Brother}

Early this morning I received a Note from the Secretary of General Washington: "My dear Law: our great and good friend General is about to leave us - I think he cannot survive thro' the night. I pray come down and if possible bring Mrs. Law - Dr. Craik, Dr. Dick and Dr. Brown are with him."

Your aff'e and afflicted friend

Tobias Lear

Mrs. Law and I arrived too late - America had lost her hero Patriot and first Character - The Croup (his complaint) seized him on Saturday about 2 o'clock in the morning and terminated his existence at $11 \mathrm{P}$. M. after a painful struggle of about 19 hours - His difficulty of breathing prevented him from speaking much, his uniform firmness and collectedness were displayed to the last moments - Dr. Craik his old friend and Physician had been with him in Braddock's defeat and in all his campaignsAll his endevours to save the General being in Vain - The Gen'l observed that he died hard but was not afraid to go - He gave his keys to Mrs. Washington and desired her to bring two wills one of them he gave as his true will and desired the other to be burnt which was done before him - he particularly desired Mr. Lear to proceed in copying and directing his under secretary $\mathrm{Mr}$. Rawlins to enter in a Book all his public Letters etc.- (he also requested not to be buried before two days exp......... then to be placed in the family vault without any ostentation) fortunately he did not want to give long directions as his almost unexampled manner and system prepared him for any event; when he was near expiring he asked the hour felt his pulse and closed his eyes and left then this world without a sigh or groan-Mrs. Washington was with him all the time, he died in Mr. Lear's arms- When Mrs. Washington asked if all hopes were fled Mr. Lear raised his hand. Mrs. Washington too well construed the token and retired, saying "My last painful task is over I only wish soon to follow him" - he did not take leave of any of the family as he had frequently disapprove of the afflicting farewells which agravated sorrow on those melancholy occasions-

On Friday night he was cheerful and read the paper to Mrs. Washington though rather hoarse - his two last favorite objects had every promise of completion- The State of Maryland had advanced 57,000 Dollars and had taken Security that the Potowmac Canal should be finished and the President had an- 


\section{POLAND AND THE AMERICAN REVOLUTIONARY WAR}

nounced is his openning Speech to Congress that the Capitol the Offices and Accommodations for Congress were ready in Washington City - he had induced Mr. Lewis his nephew and Mrs. Washington's grandson by marrying Miss Eleanor Custis to rent his distillery, Mill and Farm and had given him 4 or 500 Acres to build a house upon that he might live near him and he just made out in 12 or 14 Sheets of paper directions to his Overseers for rotations of Crops for several years - in short he had prepared for more leisure and tranquility during the decline of life. I feel too overcome to moralize on this occasion. A friend of Mr. Lear's in reply to the unwelcome tidings directed a Letter without a Line in the inside - the blank expressing more forcibly than words the excess of his grief.

Monday Evening.

My servant is returned from Alexandria whither I sent him for mourning and he informs me that all the Shops are shut that the bells are tolling and that every one appears in Black or with Crepe. Mrs. Washington sent for me this morning and displayed a solemn composure that was more distressing than flows of tears. She told me she had promised herself the pleasure of being with Mrs. Law and me in our new house but that now she shall never quit this scene - She has calmly given instructions about the funeral and I have the happiness to learn from her that I possessed the General's Esteem - I am now sitting in a Room adjoining to the cold remains which are to be deposited in the Family vault on Wednesday - He would have finished his 68-th year on the 11-th February, he was 6 feet and an inch high - his frame athletic and his constitution strong - alas! he relyed upon it too much and exposed himself without common caution to the heat in Summer and cold in Winter - On Thursday $\mathrm{He}$ visited his farm and talked with his Overseers in the rain till 3 o'clock and came home quite wet - On Friday he was cutting trees in the Sleet to open an Avenue he was forming - hence the cause of his illness - he lost his only remaining brother a few weeks ago and Mrs. Washington had just heard of the demise of her only sister. On Wednesday the last sad office will be performed.

Thursday Morning

Yesterday the Cavalry, Rifle men, Militia, Artillery and Free Masons with a vast concourse of people attended - The solemn music the minute Guns from an armed vessel on the River, the slow march of the troops with arms reversed and the long procession formed a most awful Scene - The principal Officers and the Free Masons by turns carried the body - The old Soldiers mentioned in the house affecting tales of former times in short real woe was displayed in all faces and expressed by all voices. 


\section{APPENDICES}

Mrs. Washington sent for Mr. Lear after the ceremony was performed and desired him not to close up the vault - She expected soon to be deposited by his side -

I cannot write upon any other subject, I expected to be more firm but this sudden calamity has too much depressed my spirits - Addieu

Your most affe Brother

Thomas Law

The Gen'l has left Mt. Vernon to his Nephew Judge Bushrod Washington and 4000 acres of Land - he has bequeathed 50 Potowmac Shares to the University of Washington City, 1000 pounds to a Colledge in Alexandria - his Slaves to be free and educated - his Land Houses etc. in 23 Shares to his Nephews and Mrs. Washington relations - his Estate was worth about 1200000 D's.

VI.

\section{NOTE OF ELIZA PARKE CUSTIS (MRS. THOMAS LAW)}

(MS Bibl. Czart, No. 2786, p. 9)

(A piece of velvet from the coat of George Washington, oval in shape, is pasted at the top of the card; attached to it is a piece of paper of the same shape; the paper is inscribed with the words: "Mount Vernon," in Washington's handwriting. The note reads:)

This velvet was worn by General Washington. - The words "Mount Vernon" his favorite home, and where his sacred remains are entombed, written by his hand, in a letter addressed to me hearing from my young friend Thomas Monroe, Officer of the guards in Warsaw of the high veneration which The Princess Czartoriska feels for the father of the American people - I present to the Princess these relics of him, who was first in War first in Peace, first in the hearts of his Country - as a memento of Washington - and of the satisfaction I feel, at his being so justly estimated, among the brave Polish Nation, whose gallant Sons fought for the liberty of my Country.

City of Washington

Eliza Parke Custis

April $26-1828-\quad$ Grand-daughter of Mrs. Washington.

\section{B. WASHINGTON BICENTENARY OBSERVANCES IN POLAND, JANUARY - MAY, 1932}

(Official Bulletin of the Central Committee for the Celebration in Poland of the 200th Anniversary of the Birth of George Washington.)

\section{JANUARY $9 \mathrm{TH}$}

A ball and entertainment was given by the Polish-American Society in the Reception Rooms of the Hotel Europe in Warsaw. 


\section{POLAND AND THE AMERICAN REVOLUTIONARY WAR}

Largely attended by both Poles and Americans the ball was considered one of the most successful social event of the season.

\section{FEBRUARY 3RD}

A popular pamphlet on Washington was published by the Central Committee, which was widely distributed through various social organizations to the public at large and, particularly, to school children and soldiers.

\section{FEBRUARY $8 \mathrm{TH}$}

The Czartoryski Museum of Cracow sent a volume of Washington autographs to the Historical Loan Exhibition in Washington.

\section{FEBRUARY 22ND}

A public meeting was held under the auspices of the Central Committee at Warsaw City Hall. The large audience that gathered on this occasion included the President of Poland, representatives of the American and Polish governments, the diplomatic corps and the American colony. At the conclusion of the meeting a message expressing the admiration of the Polish people for Washington was sent by the Central Committee to President Hoover. Similar commemorative exercises were held in Cracow, Lwow, Wilno, Poznan, Katowice and Gdynia. Gdynia.

Streets were named after Washington in Warsaw and

In the evening a special Washington program was broadcast by the Warsaw radio station, which was relayed by all the broadcasting stations in Poland.

\section{MAY 3RD}

A postage stamp bearing the portraits of Washington, Kosciuszko and Pulaski was issued by the Ministry of Posts and Telegraphs.

A luncheon and rally was held by the Central Committee at the Merchants' Club of Warsaw.

In Paderewski Park, Warsaw, exercises were held in conjunction with the planting of the Washington Oak and the dedication of Washington Avenue.

\section{ELIGIBILITY OF DESCENDANTS OF POLISH OFFICERS OF THE AMERICAN REVOLUTION TO THE SOCIETY OF THE CINCINNATI}

(Following are excerpts from letters of Colonel Edgar Erskine Hume, U. S. A., President of the Society of the Cincinnati in the State of Virginia, to the author, concerning this subject:)

The first and most important suggestion that I have to make is that you give some note as to the Order of the Cincinnati. 


\section{APPENDICES}

I make this suggestion not because I am myself of this old Society, but because it has played such an important role in the history of this country and because Kosciuszko was such an enthusiastic member. I do not recall any picture of him in which he is not wearing the Eagle of the Order - either alone or accompanying the cross of the Order of Virtuti Militari. We have many references to him in the records of the Cincinnati and his original Eagle is still in existence. The Memoir of Thaddeus Kosciuszko, by A. W. W. Evans, published privately for the Society of the Cincinnati (New York, 1888, about 100 pages), though its text is somewhat old fashioned, shows the everliving interest of the members of the Cincinnati in their great son. Then too August Christian George Elholm was an Original Member of the Cincinnati.

I know of no single means of bringing home to the people of both nations the important part played by Polish officers in the American Revolution than by this means. When one thinks that to-day such men as Washington, Knox, Wayne, Sullivan, Marshall, Lafayette, Rochambeau, deGrasse, Broglie, Noailles and many others are represented, one cannot doubt my opinion.

The rules for admission of officers to the Cincinnati were these: $a$ ) that the officer served as such in the Continental Line (as distinct from the militia); b) that he was in service to the end of the war; $c$ ) that he was killed in battle or died in service; $d$ ) that he was rendered supernumerary in one of the several reforms of the Army. Any officer qualifying under one of these four provisions is now eligible to be represented by his eldest male descendant. If there are no descendants of the officer, then the eldest descendants of his eldest brother or sister can enter the Cincinnati.

Thus you see that but a limited number of the Revolutionary Officers can be represented. I find that on your list of Continental Army Officers there are seven who should be represented to-day.

POLES IN THE NAVY. I do not think that any were eligible to the Cincinnati as privateer service, like militia service, did not give eligibility.

LAUZUN'S LEGION. Unquestionably the three Polish officers whose names you give, were eligible to membership in the Cincinnati. I imagine that the reason that they were not Original Members is that such membership would have had to be in the French branch, and they admitted no officer below the rank of Colonel. At present the French Society admits descendants of officers of all ranks, just as do the thirteen American branches. Hence these three officers should be represented. Many of the officers of Rochambeau's force were members of the Cincinnati and it is not without interest that to-day the French Society of the Cincinnati has a larger membership than any American state Society of the Cincinnati. 


\section{POLAND AND THE AMERICAN REVOLUTIONARY WAR}

On a separate sheet I list the whole of the eligible Polish officers, including as a note the possibility of the identity of Jerzmanowski and Jervuturas.

\section{POLISH OFFICERS OF THE AMERICAN REVOLUTION \\ WHO ARE ELIGIBLE TO BE REPRESENTED IN THE SOCIETY OF THE CINCINNATI}

1. Lieutenant Colonel the Baron de Botzen. Killed at Egg Harbor, October 15, 1778.

2. Cornet August Christian George Elholm. An Original Member of the Society of the Cincinnati in South Carolina.

3. Lieutenant Count Michael Grabowski, of the Second Squadron of Hussars, Lauzun's Legion. Served to the end of the war.

4. Brigadier General Thaddeus Kosciuszko. An Original Member of the Society of the Cincinnati (signed the Parchment Roll).

5. Colonel Michael Kowacz. Killed before Charleston, South Carolina, May 11, 1779.

6. Kraszewski. A subaltern officer, killed in battle.

8. Captain John Kwiryn Mieszkowski, Commander of the Second Squadron of Hussars, Lauzun's Legion. Served to the end of the war.

9. Brigadier General Casimir Pulaski. Died of wounds received in action before Savannah, October 11, 1779 .

10. Lieutenant George Uzdowski, First Squadron of Hussars, Lauzun's Legion. Served to the end of the war.

11. Captain John Zielinski. Commissioned April 18, 1778. Died in Service September 23, 1779.

12. It is possible that Lieutenant Jerzmanowski who served in the American Revolution and Lieutenant Jervuturas who was an Original Member are the same individual, since there is confusion in the spelling of names.

NOTE - None of the above officers have ever been represented in the Society of the Cincinnati. 


\section{INDEX}

ABBATT, Wm., quoted, 42.

Adams, John, Pres. U. S., meets Niemcewicz 161-162, m. 105, 163, 180, 196; Mrs. Adams, 161.

Adams, Herbert B., qu., 107.

Adrian, ship, 152.

Albany, N. Y., 121, 126, 131-133, 142, 178.

Albany Co., N. Y., 131.

Alexander I, Emp. of Russia, 184.

Alexandria, Va., 170, 196.

Alexandria College, 197.

Allen, Gardner W., qu., 74.

Amboy, N. J., 123, 156.

American, children, 140, 157; civil war, 22; commissioners at Paris, 1,44 ; customs, $129-130,139,145$ $146,157-158,160,182-183$; infantry 128 ; prosperity, 157; titles 157 .

American Philosophical Soc., 164, $187,190$.

Americans, in Poland, 4, 9, 198; as marksmen, 132.

Amherst, Sir Jeffrey, 138, 143.

Anderson, - , superintendent of Mt. Vernon, 175.

Andre, John, 127.

Apthorp, C. W., 125.

Armand, Charles T., Marquis de la Rouarie, 47, 97.

Armstrong, John, 19.

Arnold, Benedict, 127-128.

Atkins, - , merchant at Alexandria, Va., 170 .

Aubrey, Thomas, 137.

Augusta, Ga., 99, 101.

Austerlitz, battle of, 50 .

Austria, 1, 27, 189.

Azan, Paul, 49 n., 86 n.

BAKUT, Peter, 62.

Balch, Thomas, qu., 42, 50, 81, 83 .

Baldeski, Joseph 30, 36-38, 56.

Baltic Sea, 1; trade, 3.

Baltimore, Md., 29, 160, 184.

Balyca, Simon, 60.

Barlow, Joel, qu., 7.

Barsk, John, 57.

Bastille, 171.

Bayard, John, 158.

Bekas, George, 57.

Broga, Andrew, 57.

Beaujolais, Duke of, 164-165.

Beaumarchais, Pierre A. Caronde, 27.

Belville, S. C., 77.

Bemis' Heights, 18, 135.

Beniowski, Maurice August, 38-42, 56.

Bensell, Dr. -, at Germantown, Pa., 37.

Benson, Egbert, 129

Bentalou, Paul, qu., 28, 30, 42, 50.

Bergen, Norway, 95.

Bergen Co., N. J., 60, 111.

Berlin, Germany, 184.

Bevan, Thomas H., qu., 95.

Bethlehem, Pa., 29, 47-48.

Biddle, Christine, 187.

Bingham, Wm., 187.

Biscai, Spain, 155.

Bland, Theodoric, 41, 194.

Blaszkowicz, Charles, 106-108.

Bloody Pond, battlefield, 136.

"Blue Laws", 145.

Bluskey, Frederick O., 58.

Board of War, 39, 41, 48.

Boleslawita, see Kraszewski, J. I.

Bolich, John, 62; Peter, 62.

Bolingbroke, Lord -, 178, 186.

Bonia, John, 62.

Bonita, Henry, 62.

Bordeaux, France, 187.

Borodino, battle of, 50 .

Boston, Mass., 37, 45, 72-73, 116, $129,142-143,146,148,177-178$.

Boston, ship, 45.

Botzen, Baron - de, 30, 42-43, 200.

Bourbons, 86, 180.

Bozec, Alexander, 62.

Braddock, Edward, defeated, 195.

Brandywine, battle of, 27, 53

Brazil, 51.

Brest, France, 83.

Brigide, - , neighbor of Gen. Gates, 160.

Bristol, Engl., 152; Pa., 119, 155.

British-American war of $1812,107-$ 108; Colonial Office, 109; Museum, 106; Parliament, 4-5, 60, 111, 126; troops at N. Y., 118, 123-124; War Office, 109

Broglie, Victor C., 199.

Broome, John, daughters, 160.

Brown, Dr. Wm., 195.

Bryan, George, 48.

Burcky, Peter, 60.

Burdjat, Conrad, 61.

Burgoing, -, French Minister at Hamburg, 5-6.

Burgoyne, Sir John, 17, 109, 128, 131, 134, 137-138. 


\section{INDEX}

CAMBRIDGE, Mass., 178.

Camden, S. C., 19, 159.

Campbell, Thomas, lines on Kosciuszko, 20.

Canada, 108, 109, 143.

Canadian travelers, 138.

Caracas, Venezuela, 179.

Carareych, Heronimus, 61.

Carleton, Sir Guy, 124.

Catherine II, Empress of Russia, 3, $5,115$.

Catskill Mts., 130.

Cause, John, 72.

Caza - Irujo, Carlos Martinez, Marquis de, 164.

Chalupetzky, Joseph, 57.

Champagne, France, 140, 147.

Champlain, Lake, 116, 138.

Channing, Edward qu., 18.

Charleston, S. C., 19, 30, 31, 43, 47, $49,50,56,73-77,120,157,200$.

Charlestown Township, R. I., 145.

Chickasaw Indians, 164

Chreptowicz, Count -, 116.

Church, Mrs. John Barker, 165, 178.

Cisko, Thomas, 64.

Clark, Abraham, 181.

Clarke, Alured, 124; family of Phila., 187; Sir Francis, 134.

Clerc, John, 140.

Clermont, N. Y., 143.

Clinton, George, 129.

Clinton, Henry, 108-110, 127, 131.

Coffin, - Col., 139

Cohoes Falls, N. Y., 133-134.

Confederacy of $\mathrm{Bar}, 38,43,44,52$, $54,70-71,75,89,93-94,96$.

Clongress, U. S., 99, 100, 153, 164, $169,195$.

Connecticut, River, 144; State, 57, 116, 144-145, 177.

Constitution Isl., 128.

Continental Congress, $1,6,18,20$, $27-30,37,39-41,54,55,69,71-$ $73,118,120,147,159$.

Coolidge, Caleb, 72 .

Copenhagen, Denmark, 90, 94.

Copera, Francis, 64.

Cork, Ireland, 146.

Cornwallis, Charles, 71, 84, 120.

Cossacks 1, 3.

Cracow, Poland, 7, 9, 94, 198.

Craik, Dr. James, 195.

Creek Indians, 99, 100.

Crevecoeur, Hector St. John de, 115116.

Croton River, 126.

Crown Point, N. Y., 138.

Crump, Abner, 9.

Custis, Eleanor Parke, 171, 172, 176, 196; Elizabeth Parke, see Mrs.
Law; George Washington Parke, 171-172; Martha Parke, see Mrs. Peter.

Czartoryski, Adam C., 179, 182, 185; Adam G., 180, 188; family, 176, 184; Museum, 193, 198.

DANES in U. S., 90 .

Danish Institute of Genealogy, 90.

Dantzig, Poland, 1, 2, 179.

Dartmouth College, 10.

Davie, Wm. R., 56 .

Davis, Dwight F., qu., 18-19.

Dayton, family, 179; Horace, 183 ; Wm., 181, 184.

Deane, Silas, 36, 44.

Deasky, Leman, 59.

Debrosky, John, 64.

Declaration of Ind., 9, 17.

Delaware, River, 46, 119, 153, 155156; State, 57, 160.

Delwich, Clasimir, 62.

Denmark, 1, 90, 94; archives, 91.

Deskey, John, 58.

Desko, Samuel, 58.

Diamond Isl., 137.

Dick, Dr. Elisha C., 195.

Dickinson, John, 118-119, 146-148.

Dieskau, Ludwig Baron, 136.

Dogget, Samuel, 72.

Dolo, Joseph, 62.

Doman, John, 62; Mark, 62.

Dombrowski, John H., 13.

Donald, A., 11 n.

Donich, Henry, 62.

Douglas, - , Miss and brother, 188

Draper, Lyman C., 89-90.

Dresden, Germany, 179; Me., 85.

Dubienka, Poland, 9.

Du Pont de Nemours, Pierre, 180.

Dusky, John, 57.

Dutchess Co., N. Y., 140.

Dutchmer in U. S., 131, 140, 156, 178.

EASCO Bay, 106.

East River, 125, 144.

Eastern Prussia, Dietine of, 5 .

Easton, Pa., 48.

Eden, Wm., 3.

Egg Harbor, N. J., battle of, 30, 42, 200.

Elba Isl., 51, 180.

Elbe River, 50.

Elholm, Abraham H., 95; Abraham A., 96; Anne A., 95-96; August C. G., $43,56,87-101,199,200$; District, 100 ; farm, 95; Hans A., 95-96; Mons A., 96; Niels A., 95.

Elizabeth, Cape, 106; N. J., 122-23, 158, 161; Niemcewicz at, 178-187. 


\section{INDEX}

Elliott, family of Phila., 165.

Elster River, 50.

Emancipation Procl., 21.

England, 2-4, 21, 69, 73, 75, 115, 132, $146,152,154,159,173,175,186-$ $187,189$.

Englishmen in Poland, 4.

Esopus, N. Y., 131.

Estaing, Charles Henri Theodat, Comte D', 31.

Evans, A. W. W., 199.

FABRICIUS, John C., 57.

Faust, A. B., qu., 91.

Fayssoux, P., 39.

Ferguson, Patrick, 30, 42.

Fishkill River, 135.

Fiume, Hungary, 39.

Florida, 6, 75; Eastern, 75-76.

Fontenill, - de, companion of Wengierski, 118.

Ford, Worthington, C., qu., 109.

Fort, Arnold, 128; Clinton, 109, 127 -128; Constitution, 109; Edward, 135, 139; Knyphausen, 84, 126; Lee, 126; Montgomery, 109, 128; Putnam, 128; St. Frederic, 138; Washington, 108, 126.

Fourteen Miles Isl., 137.

France, assists Am. 18, 81-86; Am. sympathies, $115-116$; m., $38,44-$ $45,50-51,53,71,82,117,140,165$. $179,180,187,189$.

Frankford, Pa., 155 .

Franklin, Benjamin, 27, 36, 44, 179, 186; State, 91-93, 98-101.

Franko, Michael, 58.

Frederick II, King of Prussia, 1-3, 47, 91, 96, 162.

Freeman's Farm, battlefield, 135.

Freemasons, 6, 179, 196.

Freire, Cipriano R., 167; Mrs. Freire, 163.

French, -, Brit. Capt., 97.

French archives, $82-86$; army in Am., 81-86, 145; Consul at Phila., 164; Directory, 164; Ministry of War, 81; Navy, 81; refugees 178179; Revolution, $85-86$, 115; Soc. of Cincinnati, 199

Frenchmen in Pulaski Leg., 29.

Frey, Charles Baron de, 46.

Fundy Bay, 106, 123.

GABRIEL, Joseph, 64.

Gallagher, M. J., Bishop, qu., 28.

Gallatin, Albert, 164, 189.

Gardner, Monica, qu., 19.

Garny, Adam, 62.

Gass, - of N. Brunswick, 162.

Gaszynski, Constantine, 51-53.

Gates, Horatio, host to Kosciuszko,
158-160; m. 17-19, 21, 154; Mrs.

Gates, 159 .

Gdynia, Poland, 198

Geneva, Switzerland, 164.

George, Lake, 116, 137-139.

George III, Brit. King, 3, 124; IV., 148.

Georgetown, D. C., 167, 176.

Georgia, 49, 57, 98-100, 146; Liberty Co., 73; Richmond Co., 76; University, 92.

German, army, 128; mercenary troops in Am., 2, 106-107,120,144, 156

Germans, in Pulaski Legion 29; $\mathrm{Be}-$ niowski plans to form a Legion of, 40; in Lauzun's Legion, 81; in Rhinebeck Township, 131.

Germantown, Pa., 37.

Germany, 71, 91.

Gibbs, Mr. -, 189

Girardot, -, Baron de, qu., 9 n

Gloucester, Va., battle of, 84 .

Godfrey, Josiah, 72.

Gordon, Wm., qu., 9, 11 n., 31; Wm. W., qu., 28, 31 .

Grabowski, - Adj. to Gen. Clinton, 108-110, 127-128; John, 82, 108, 110; Clount Michael, 82-86, 200. Grant, James, 106-107.

Grasse-Tilly, Francois Joseph Paul, Comte De, 199.

Graves, Wm., 76.

Greene, Nathanael, $19-20,84,120$ 121.

Grew, Joseph S., qu., 23.

Griffin, Martin I. J., qu., 52.

Grodno, Poland, 11.

Groell, Michael, 6.

Groton, Conn., 144

Guadaloupe Isl., 178.

HACKENSACK, N. J., 60, 111.

Haddonfield, N. J., 29.

Hallicia, John, 64.

Hamburg, Germany, 165, 184.

Hamilton, Alexander, $132-3,180$; Hienry, 124.

Hampton, Va., 84.

Hand, Edward, 46.

Harrison, Wm. H., Pres. U. S., qu., 23.

Hartley, Herbert, 74.

Hauch-Fausboell, -, Director, Danish Inst. of Geneal., qu., 90-91, 94.

Havana, Cuba, 165.

Haverstraw Bay, 126.

Heath, Wm., 60.

Heintz, Jean de, 6

Heitman, Francis B., qu., 36, 43, 47, $50,52,54,91,96-97$. 


\section{INDEX}

Heligoland Isl. 51.

Hellgate, 144; Club, 160.

Hendrick, Indian chief, 136.

Heymann, Baron - de, qu., 86.

Hildt, John C., qu., 3.

Hobart, John Henry, Bishop, 181.

Hoboken, N. J., 158.

Holland, 1, 7; Land Co., 7.

Holland, Samuel, 106.

Holstein, Duchy of, 90-92, 96; Poland, 93.

Holston River, 98.

Hoover, Herbert C., Pres. U. S., 31, 198.

Hopkins, - Major, 137.

Horry, Peter, 97.

Howe, George Augustus, 137; Wm., 27.

Hrabowski, Mrs. Ann, 74-77; John Samuel, 75-77; Samuel, 74-77.

Hudson River, 83, 116, 125-127, 133 $-135,185$.

Hume, Edgar Erskine, qu., 10 n., $198-200$

Humphreys, David, 7; qu., 8, 11.

Hungarians, in Lauzun's Leg., 81.

Hungary, 38, 56.

Huntington, J., 60.

Huntington, N. Y., 144.

ICAISKY, Jesse, 57.

Indians, $30,46,48,99,136-137$, $139,141-2,164$.

Intrepid, ship, 41

Ireland, 122, 146, 148.

Isaki, August, 59 .

Italy, 13, 85, 158.

JAGIELLONIAN, University, 94; Library, 116.

Jamaica Island, 118, 152.

James Island, 19.

Jay, John, 160.

Jeefe Rinas, Caessimgir, 61.

Jefferson, Thomas, Pres. U. S., 5-6, $10,21,164-165,177-180$.

Jervuturas, - orig. member of the Soc. of the Cinc. 200.

Jerzmanowski, -, Rev. off., 43, 200.

Johnson, - Brit, off., 127; Miss 160; Joseph, qu., 39, 47, 49; Sir Wm., 136.

Jones, - , killed in duel, 169; John Paul, 5, 7, 74; K. C., qu. 52.

Jullien, -, German deserter, 42.

KAGHAATSKO, Nicholas, 61. Kalb, Baron John de, 42.

Kalm, Peter, 129.

Kalussowski, Henry, 49, 54.

Kamchatka, 38

Kapp, Friedrich, qu., 2, 111. 204
Karczew, Poland, 82.

Karlinski, Kasper, 94.

Katowice, Poland, 198

Kean, family, 185 n., 188; Peter Philip James, 180, 182, 185, 188; Mrs. Susan, 179-181, 184-188.

Kinderhook, N. Y., 132, 142.

King's Bridge, N. Y., 84, 126.

King's Mt., 98.

Kingston, N. J., 156, 162; N. Y., 109, 131.

Knias, Jacob, 62.

Kniaziewicz, Charles, 13.

Knights of Divine Providence, 6.

Knox, Henry, 121, 128-129, 199.

Kokogai, Samuel, 62.

Konopezynski, Ladislaus, qu., 3, 94.

Kookogey, S. M., qu., 62-63 n.

Korzon, Thaddeus, qu., 52.

Kosciuszko, Thaddeus, 15-23; second visit in Am., 151-167; m. 5, 7$10,12-13,27,35-36,50,52,56$, $65,120,144,148,171,177,179$, 199-200; Garden, 19, 178; Insurrection, $8-10,20,164$.

Koslow, Jacob, 64.

Kotkowski, -, Rev. off., 43-47, m. 36.

Kowacz, Michael, 47-49, m. 200.

Kowan, Jacob, 63.

Kozlowski, W. M., qu., 51, 55.

Kracolo, Henry, 63.

Krak, Godlieb, 61.

Kraszewski, -, Rev. off., 49, 200; Joseph I., qu., 43, 49, 54.

Kruegers, -, merchant of N. Y., 159. Kuraw, Michael G., 61.

Kushel, Joseph, 61.

Kusky, Barnados, 63.

Kuyawy, Poland, 53.

LAFAYETTE, Marie de Motier, Marquis de, 54, 120-121, 161, 171, $173,194,199$.

La Jambe, -, French Consul at Phila., 164

Landers, H. L., qu., 18.

Laneville, Mons. -, 194.

Laskey, Hugh, James, John, Nathaniel and others, 58; George, 62.

Laski, John, $58 \mathrm{n}$.

Laurens, Henry, 45; John, 30.

Lauzun, Armand Louis de Gontaut Biron, Duke de, $81-86$; Legion, $81-85,199-200$.

Law, Thomas, 164, 167, 170, 172; letter on the death of Washington, 195-197; Mrs. Law, 163, 167-169, $170,172,195-197$.

Lear, Tobias, 195-197.

Lebanon, Conn., 83, 177. 


\section{INDEX}

Ledyard, John, 5 .

Lee, Charles, 4; Frederick, 152; Richard Henry, 27, 97.

Leipzig, battle of, 50 .

Leshinskey, Sigmund, 63.

Levasvick, George, 63.

Levers, Robert, 48.

Lewis, Lawrence, 196; Morgan, 132.

Libiszewski, -, companion of $\mathrm{Ko}$ sciuszko, 165 .

Library of Congress, 72.

Lincoln, Abraham, Pres. U. S., 2122 ; Benjamin, 18, 30, 31, 84 .

Lisbon, Portugal, 7.

Lithuania, 70.

Litomski, Charles, 50-51.

Littlepage, Louis, 5, 9, 11.

Little Turtle, Indian chief, 163.

Livingston, Edward, 160; John, 160 ; Philip, 185; Robert R., 131, 132, 143; Manor, 129.

Logan, family, 165, 187.

Lomza, Poland, 94.

London, Engl., 2, 74, 76, 177, 184.

Longfellow, Henry W., 29.

Long Island, $123-125,144$.

Lossing, Benson, qu., 28, 50, 110.

Loughaski, Matthias, 65.

Louis, XIV, French King, 164; XVI, 81, 84; Philip (Duke of Orleans), $164-165$.

Loveson, Mrs. -, of Phila., 152.

Lovick, Moses, 62.

Lovzinski, Baron de, Interesting History of, $65 \mathrm{n}$.

Lower Paramus, N. J., 60.

Ludlow, Louis, qu., 27.

Luske, Soloman, 57.

Lwow, Poland, 198.

McCORMACK, John W., qu., 29, 31.

McDonald, Wm., qu., 27.

Maciejowice, Poland, 9, 151.

McIntosh, -, Major, qu., 90, 92; John, 90, 92, 97-98.

McKean, Thomas, 105.

Maclay, E. S., qu., 74 .

Madagaskar Isl., 38, 41.

Madison, James, Pres. U. S., 5, 10 n., 41.

Majorat of Nieswiez, archives, 70.

Malcolm, -, secretary to Pres. Adams, 161.

Malick, Andrew, 59; John, of N. J., 59 ; of N. Y., 61 .

Malta, Isl., 173; Grand Master of the Order of, 178.

Manchester, Engl. 143.

Manhattan Isl., 126.

Mann, Abraham, 183-184.

Mlarblehead, Mass., 51, 58.

Margart, John, 49

Mark, Father, Polish patriot, 41.

Marseilles, France, 148.

Marshall, John, 184, 199.

Martinique, Isl., 116-117, 178.

Maryland, Governor of, 71; Historical Society, 29; State, 57, 170, 195;

Masney, Thomas, 57.

Massachusetts, Archives, 72; Council, $72 ;$ m. 58, 143, 145.

Matthews, George, 99-101.

Matuszewicz, Thaddeus, 184.

Mazovia, Poland, 6.

Mazzei, Philip, 5.

Miami Indians, 163.

Midera, Samuel, 63

Mieszkowski, John Kwiryn, 82-86, 200.

Mifflin, Thomas, 153.

Miklaszewicz, Anthony, 70; Felix, $69-74$.

Minisink, N. J., 46.

Miranda, Francisco, 179.

Mississippi River, 165, 174.

Mitchell, Henry, qu., 107.

Mitsco, Conrad, 63.

Mohawk, Indians, 141; River; 133134, 140-141.

Mohilow, Poland, 70.

Monk's Corner, skirmish at, 97.

Monroe, Thomas, 197.

Montjoie, -, companion of the Duke of Orleans, 164.

Montpensier, Duke of, 164-165.

Moravians, 29; Diaries qu., 47-48.

Moreau, Jean Victor Marie, 179.

Morgan, Daniel, 18.

Morris, Gouverneur, 179; Robert, 73.

Moscau, Russia, 50.

Moscicki, Henry, qu., 49 n.; Ignace, Pres. of Poland, 198.

Mostowski, Paul, 6.

Moultrie, John, 75.

Mt. Independence, 17.

Mt. Vernon, Niemcewicz at, 170176; description, $170-172$; m. 12 , 121, 169, 184, 197.

Moylan, Stephen, 54-55.

Myers, Max, 72 .

NANCY, France, 86.

Napoleon, Emperor of France, 21, $50-51,85-86,165,179-180,186$. Narragansett Bay, 108, 145.

Negroes, 118, 178; will of Kosciuszko, $21-22$.

Nelson, - , of N. Brunswick, 161.

Neshaminy Falls, Pa., 27.

New Amsterdam, 60.

Newark, N. J., 123, 158, 161, 186. 


\section{INDEX}

New Brunswick, N. J., 21, 122, 154, $156-158,161,184$.

New England, 72, 109, 145-146, 169.

New Hampshire, 59, 145-146.

New Haven, Conn., 144.

New Jersey, 30, 47, 59, 84, 111, 120 , $125-126,155-156$.

New London, Conn., 144.

New Orleans, La., 165.

"New Poland" in Am., 6.

Newport, R. I., 81, 108, 144-146.

Newton Township, N. Y., 139.

New York, City, description, 123124; Washington's funeral, 179; yellow fever, 178; m. 60, 69, 109, $111,118,122,139,143-144,156$, $158-159,161,169,179,185,187$; State, 3, 21, 47, 60-61, 72, 126, 180; Historical Soc., 6.

Niagara, 141, 186.

Niemcewicz, Julian Ursyn, in U. S., $151-190$; at Mt. Vernon, 166 176; marriage to Mrs. Kean, 181; publishes Washington's biography $184 ; \mathrm{m} .12$

Niemerich, Godlieb, 63.

Niskayuna, N. Y., 140.

Noailles, Louis Marie, Viscount De, 199.

Norfolk, Va., 168, 184.

North Carolina, 6, 62, 84, 98-100.

North River, 158, 160, 186.

Norway, 94, 95-96; archives, 95.

OBLEFFSIKIE, Frederick, 59.

Ogden, Aaron, 186; family, 179.

Ogeechee River, 97.

Olsztyn, (Holstein), Poland, 93-94.

Onondaga Indians, 141.

Osborne, John Ball, qu., 94-95.

Oslo, Norway, 95.

PALMER, Wm. K., qu., 22, 31.

Paris, France, 1, 42, 51, 56, 115, 139, $184-185,188-189$

Pasko, John, 59.

Passaic River, 161.

Paterson, Wm., 158.

Patterson, Robert, 164, 187.

Paul I, Emp. of Russia, 20, 151.

Pawcatuck River, 145.

Pemberton, family, 165, 187.

Peninsular War, 50.

Penn, Wm. 153, 165 .

Pennsylvania, 47, 62-64; legislature, 153-154.

Penobscot Bay, Me., 106.

Percy, Hugh, 108.

Pesko, Robert, 59.

Peter, Thomas, 167; Mrs. Peter, 167$169,176$.

Philadelphia, Pa., Wengierski at,
118-119; Kosciuszko and Niemcewicz at, $152-154,162-166 ; \mathrm{m}$. $21,27,37,40,51,130,155,156$, $158,179,184187$.

Philipse, Frederick, 126.

Pitt, Wm., 180.

Pleasant River, 106.

Plymouth, Engl., 39; Mass., 107.

Pochard, Nancy, 85.

Polan, Joseph, 59.

Poland, influence on Am. Rev., 1-3, attitude toward Am. Rev., 6-7; object of Am. sympathies, 7-11, 13 ; m. 21, 32, 38, 43-44, 75, 81, 89 , $92-94,96,101,108,115,147,151$, $160,165-166,172,174,182-184$, 187-188; Central Com. for the Celebration of Wiashington's Bicent., 197-198; Embassy of, 193.

Polaskie, Anthony, 61.

Poleresky, John, 82-86.

Poles, in Lauzun's Leg., $81-86$; Loyalists, 103-111; in Miranda exped., 179; Pulaski Leg., 29, 36$56,63,65,89-101$; Rev. Army, Army, 15-77, 199-200; Rev. Navy, $69-74$.

Polish, Academy of Sciences, 7; American Soc., 197; Brethren, 178; Colonial immigration in U. S., 35 , 56-65, 105; exiles, 189; Legions in Napoleonic Wars, 13,165 ; Military Ácademy, 182; National Museums, 9; Revolution of 1831,53 , $187-188$.

Polock, Poland, 69.

Polopells Isl., 129.

Poloske, Elham, 61.

Poniatowski, Joseph Prince, 50.

Pons, - Marquis de, French Minister at Berlin, $1 \mathrm{n}$.

Portland, Me., 174.

Porto Rico, 118

Port Royal, Jamaica, 118.

Portsmouth, Engl., 39; Mass., 146.

Potocki, Anthony, qu. 41; Count John, 6 ; family, 160 .

Potomac, Canal, 195; River, 170, 172, 176.

Poughkeepsie, N. Y., 129, 131.

Poznan, Poland, 198.

Prevost, Augustine, 30.

Prince Radziwill, ship, 70-73.

Princeton, N. J., $120-122 ; 156$; College, 156, 185.

Providence, R. I., 45, 146.

Prussia, attitude toward U. S. and Poland, $1-3 ; \mathrm{m}$. 27, 186.

Pulaski, Clasimir, 25-32; m. 3, 7, 13, $35-37,39,40,42-45,47,50,52-$ 55, 65, 71, 93-94, 97, 200; Legion, 


\section{INDEX}

$29-31,36-38,42,45-50,53-\mid$ Senegal, 81-82.

$56,96-97,200$.

Pulawy, Poland, 165, 172, 176, 184185.

QUAKERS, 135-136, 160, 165, 187; customs, $119-120$.

RADUCZ, Poland, 52-53.

Radziwill, Prince Charles, 70-71.

Rahl, -, German Col., 120.

Ramsey, J. G. M., qu., 92, 99.

Raritan River, 122, 156, 161.

Rawdon, Lord Francis, 110, 120.

Raynal, Thomas, qu., 6, 139.

Rey, Andre, 64.

Rhode Island, 83, 143-145.

Ricketts, family, 179, 181, 184.

Ripley, John Phillips, 10.

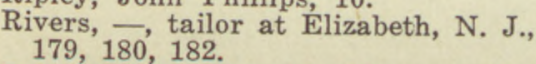

Rochambeau, Donatien M. J. de Vimuere, Viscount De, 83-84, 199.

Rockland, N. Y., 126.

Rocky Hill, N. J., 120.

Rogowski, Matthias, 43, 51-53.

Rosonoschy, Donder, 59.

Rulhiere, Claude C. de, 27.

Rush, Benjamin, 152, 154, 187.

Russell, family, of Plymouth, Mass., 107.

Russia, attitude toward U. S., 1-3; oppressive acts in Poland, 11, 38, 151, 181; m. 27, 43, 50, 186.

Rutgers, Mrs. -, 185.

Rutherfurd, Robert, 186.

SADOWSKY, Jacob, 64.

St. Augustine, Fla., 75-76.

St. Clair, Arthur, 17-18.

St. John's River, Fla., 75-76; N. F., 106.

St. Petersburg, Russia, 20, 151.

St. Pierre, Martinique, 117.

Sanduskie, Jonathan, 64.

Sandusky, Anthony, 64.

Sandy Hook, N. Y., 123.

Santo Domingo, 118, 178.

Saratoga, battle of, 18, 109, 128; battlefield, $134-135$, m. 116, 134, 159.

Sassacus, Indian chief, 144.

Savannah, Ga., 30-31, 39, 43, 50, $53,55,97,200$.

Saville, -, Rev. soldier, 55.

Scandola, Dr. -, of N. Y., 178.

Schenectady, N.'Y., 139, 141.

Schuykill River, 153.

Schuyler, Philip, 17, 121, 132, 135, 139, 178.

Scotch Trick, ship, 71-72.

Scotland, 146.

Seduskey, James, 64.

Sevier, John, 81, 98-101.

Shaking Quakers, $142-3,178$.

Siarczynski, F., 6.

Siberia, 41 .

Six Nations, Indians, 164.

Skoki, Poland, 185.

Slowacki, Julius, 41.

Smith, E. Talbot, q., 95-96; Joshua Hett, 127; Robert, 160.

Snaughder, Thomas, 65.

Snowden, Richard, qu., 31.

Society of the Cincinnati, 9 n., 10 n., 20, 89, 198-200.

Sohake, John, 61.

Soleure, Switzerland, 22.

South Carolina, 6, 30, 73, 76, 97, 120.

Spain, 75-76, 172

Spanish, Consul, 155; Minister, 164.

Sparks, Jared, qu., 5, 32, 51.

Springfield, N. J., 158.

Sproule, George, 106.

Spuyten Duyvil, N. Y., 126.

Stach, Richard, 63.

Stadnitski, Peter, 7 .

Stanislaus Augustus, King of Poland, attitude toward U. S., 4, 11; object of Am. sympathies, 7-8; admires Washington, $11 ; \mathrm{m} .70,82$, $93,108,164$.

Staten Island, 123, 180.

Stedman, Charles, qu., 110 .

Stephenson, family, 160.

Steuben, Baron F., 40-41, 111.

Stevens, Wm. Bacon, qu., 92.

Stillwater, N. Y., 134-135.

Stockholm, Sweden, arch., 94-95.

Stone, Edwin M., qu., 52.

Stonington, Conn., 144.

Stono Ferry, S. C., 56.

Stony Point, N. Y., 126-127.

Stormont, D. M., 45.

Strong, J. B., qu., 17.

Suffolk, Earl of, qu., 3.

Sugar Loaf Hill, N. Y., 17.

Sullivan, John, 45, 194, 199.

Sussex Court House, N. J., 45.

Svendsen, H. Bloom, qu., 95.

Swanson, Miss Ann, 77.

Sweden, 1, 21, 152; invasion of $\mathrm{Po-}$ land, 1.

Switzerland, 140.

Sydney, Algernon, 4.

Szczorsy, Poland, 116.

TAPPAN SEA, 126.

Tarleton, Banastre, 84.

Tartars, 1.

Tefft, J. K., qu., 50, 89-90.

Telfair, Edward, 101. 


\section{INDEX}

Tennessee, 89, 101.

Terlecki, -, Rev. off., 54.

Thames River, Conn., 144.

Thompson, Charles, 122.

Ticonderoga, N. Y., 17, 137-138.

Tilliskey, Jacob, 54, 58.

Tipton, John, 99-100; party 93, 96, 100.

Tories, Poles among, 103-111; m. $30,46-47,76,105,123-125$.

Trenton, N. J., 28, 47, 119-120, 156.

Trevelyan, Sir Geo. O., qu., 18.

Trumbull, John, 172, 177; Jonathan, 83, 177.

Tucker, - ship capt., 45.

Tudor, Mrs. -, of Boston, 146.

Turkey, 1, 3.

Tuscany, 1.

Tuscarora Indians, 141.

Two Brothers, ship, 51.

Tysnes parish, Norway, 95.

UNITED STATES, population, 122; description, 154-155.

Ursino, N. J., 185, 188.

Ursynow, Poland, 182

Uzdowski, George, 82-86, 200.

VALLEY FORGE, 28-29, 46-47.

Vaughan, Sir John, 131.

Vergennes, C. Gravier, Comte De, $27,41$.

Vernon, Mr., - companion of Wengierski, 119.

Verplancks Point, N. Y., 126-127.

Viga, P. S., 90.

Vilette, Mr. and Mrs., 160.

Virginia, 5-6, 9, 41, 64, 122, 159, $166,175$.

Vistula River, 2.

WAGENER, J. A., qu., 91, 99.

Ward, Townsend, qu., 37.

Warren Tavern, Pa., 28.

Warsaw, Poland, 5, 7, 9, 53, 70, 81, $83,110,115,127,184-185,197-$ 198; Grand Duchy of, 186.

Washington, Bushrod, 197.

Washington, George, friendship for Poland, 12-13, 168, 174; entertains Wengierski, 120-121; entertains Niemcewicz, 167-176; lines of Niemcewicz on, 174; death and funeral, 13, 176, 179, 195-197; $\mathrm{m}$. $6,8,9,19,23,27-30,32,40-41$, $43-47,54-55,60,83-84,116$,
$120-122,128,132,144,152-153$

$156,163,167,179-180,184$,

197, 199; letters to: Kosciuszko, 193; Niemcewicz, 12, 176; Lafayette, 194; Bicentennial Observances in Poland, 197-198.

Washington, Martha, 41, 163-164, $168,171-176,195-197$.

Washington, D. C., 166, 170, 180181, 196.

Watauga River, 98

Wayne, Anthony, 29, 127, 199.

Webster, James, 127.

Weems, Rev. Mason, 184.

Wengierski, Thomas Cajetan, in America, 113-148; qu., 109-110; m. 177.

Westfall, Daniel, 46.

West Indies, 116, 178.

West Point, N. Y., 18-19, 121, 125, $128-129,135,178,185$.

Whigs, 46, 76, 105, 144; Whig Club, 160.

Whipple, Abraham, 45.

White, Anthony Walton, 21, 154, 156 $-157,161-162,184$; Rev. George, qu., 89-92, 97, 98; John, 97.

Williams, Jonathan, 185-186; Samuel Cole, qu., 89, 92, 96-97, 99 -101 .

Williamson, Hugh, 185; family, 179.

Wilmington, Dela., 84.

Wilno, Poland, 198.

Wilson, Woodrow, Pres. U. S., qu., 18.

Wing, Joshua, 71

Wingsfalls, N. Y., 135.

Winnings, Mr. and Mrs., 160.

Winship, N., qu., 90-91.

Winslow, Edward, 107.

Wisconsin, Historical Soc. of, 90, 93.

Witebsk, Poland, 69.

Wright, Thomas, 106.

Wybicki, Joseph, qu., 7.

Wyoming Valley, $\mathrm{Pa}$., 48.

YANELETZ, Frederick, 64.

Yorktown, Va., 71, 83-84, 132.

ZABRISKIE, Albert, 111; Albrecht, 60, 111; Jacob C. 60; John, 60, 111; Peter, 60; Yost, 60 .

Zabrisky, John C., 61.

Zawadooski, Peter, 57.

Zielinski, John 54-56, 200.

ERRATA. - The name of Gordon, W. H., in notes on p. p. 28 and 31 should be changed to Gordon, W. W. - Fort Putman on p. 128 should be corrected Fort Putnam. - The names of Mr. and Mrs. Peters on p. p. 167, 169 and 176 should be corrected Peter.

208 



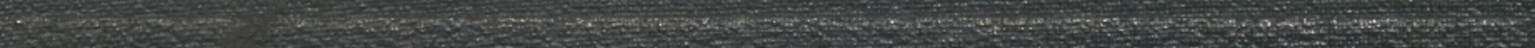

$\sin ^{2} \rightarrow$

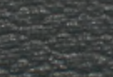

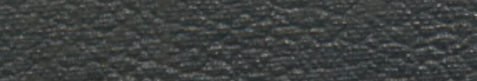

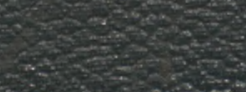

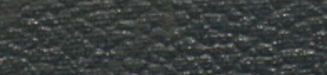

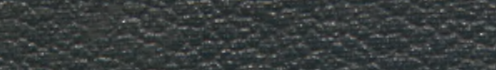

(1).

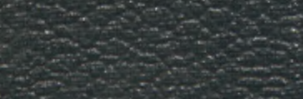

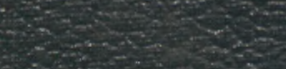

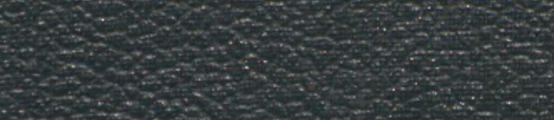

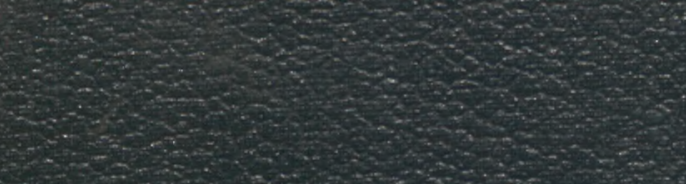

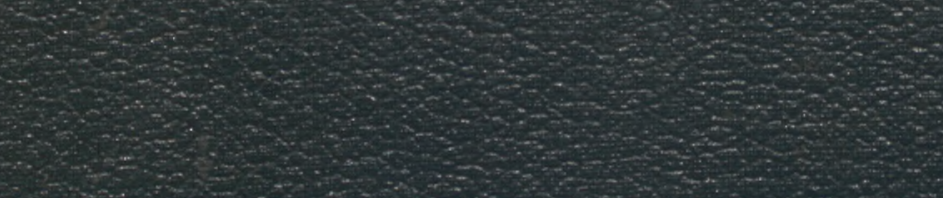

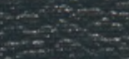

